Nevada

Environmental

Restoration

Project

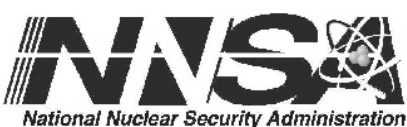

Post-Closure Inspection Report for the Tonopah Test Range, Nevada

For Calendar Year 2005

Controlled Copy No.:

Revision: 0

June 2006

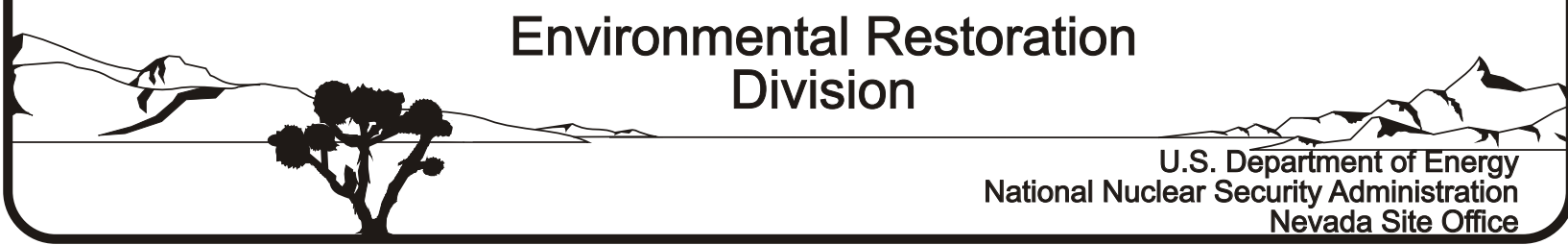




\section{DISCLAIMER}

Reference herein to any specific commercial product, process, or service by trade name, trademark, manufacturer, or otherwise, does not necessarily constitute or imply its endorsement, recommendation, or favoring by the U.S. Government or any agency thereof or its contractors or subcontractors.

This report has been reproduced directly from the best available copy.

Available for sale to the public from:

U.S. Department of Commerce

National Technical Information Service

5285 Port Royal Road

Springfield, VA 22161-0002

Telephone: (800) 553-6847

Fax: (703) 605-6900

E-mail: orders@ntis.gov

Online ordering: http://www.ntis.gov/ordering.htm

Available electronically at http://www.osti.gov/bridge.

Available for a processing fee to the U.S. Department of Energy and its contractors, in paper, from:

U.S. Department of Energy

Office of Scientific and Technical Information

P.O. Box 62

Oak Ridge, TN 37831-0062

Telephone: (865) 576-8401

Fax: (865) 576-5728

E-mail: reports@adonis.osti.gov 


\title{
POST-CLOSURE INSPECTION REPORT FOR THE TONOPAH TEST RANGE, NEVADA
}

\section{FOR CALENDAR YEAR 2005}

\author{
U.S. Department of Energy \\ National Nuclear Security Administration \\ Nevada Site Office \\ Las Vegas, Nevada
}

Controlled Copy No.

Revision: 0

June 2006 
THIS PAGE INTENTIONALLY LEFT BLANK 


\title{
POST-CLOSURE INSPECTION REPORT FOR THE TONOPAH TEST RANGE, NEVADA
}

\author{
FOR CALENDAR YEAR 2005
}

Approved By:

SIGNATURE APPROVED

Date:

6/13/06

Kevin J. Cabble,

Federal Industrial Sites Sub-Project Director,

Environmental Restoration Project

Approved By:

SIGNATURE APPROVED

Date: _ 6/13/06

Janet L. Appenzeller-Wing,

Federal Project Director,

Environmental Restoration Project 
THIS PAGE INTENTIONALLY LEFT BLANK 


\section{TABLE OF CONTENTS}

ACRONYMS AND ABBREVIATIONS ……………............................................................ vii

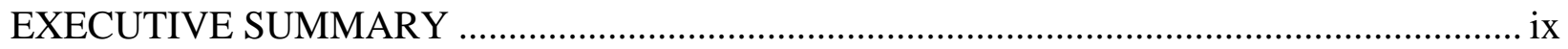

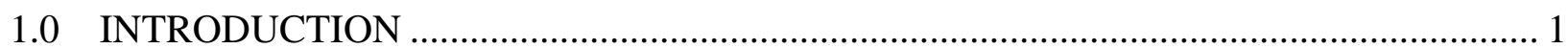

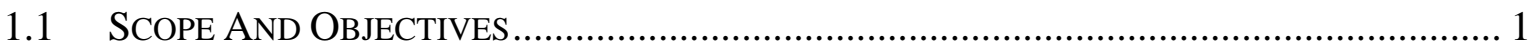

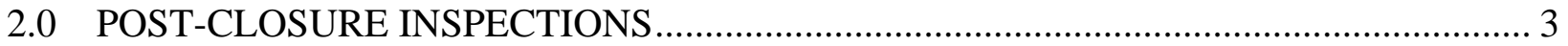

2.1 CAU 400: BOMBLET PIT AND FIVE PoINTS LANDFILl (TTR) …………………....... 3

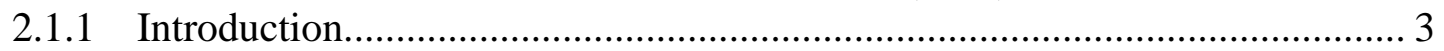

2.1.2 CAU 400 Inspection Results ........................................................................... 3

2.1.3 CAU 400 Maintenance and Repairs ................................................................ 4

2.1.4 CAU 400 Conclusions and Recommendations................................................ 4

2.2 CAU 404: RolLER COASTER LAGOONS AND TRENCH (TTR) …………………........ 4

2.2.1 Introduction........................................................................................ 4

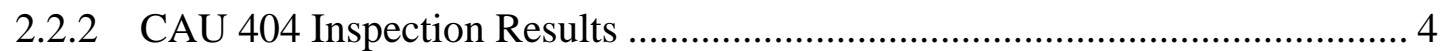

2.2.3 CAU 404 Maintenance and Repairs ............................................................... 5

2.2.4 CAU 404 Conclusions and Recommendations................................................ 5

2.3 CAU 407: RolLER COASTER RADSAFE AREA (TTR) …………………………........ 5

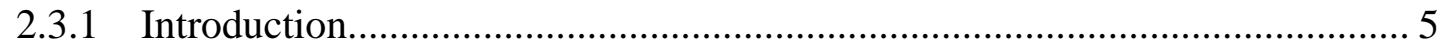

2.3.2 CAU 407 Inspection Results ..................................................................... 5

2.3.3 CAU 407 Maintenance and Repairs .............................................................. 6

2.3.4 CAU 407 Conclusions and Recommendations.............................................. 6

2.4 CAU 423: Area 3 Underground Discharge Point, BuILDing 0360 (TTR).......... 6

2.4.1 Introduction......................................................................................... 6

2.4.2 CAU 423 Inspection Results .................................................................. 6

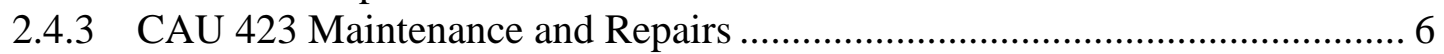

2.4.4 CAU 423 Conclusions and Recommendations................................................ 6

2.5 CAU 424: AREA 3 LANDFILL CoMPLEXES (TTR) …………………........................ 7

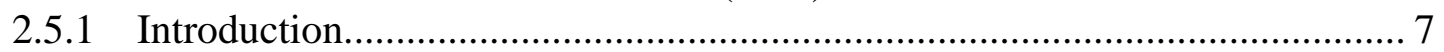

2.5.2 CAU 424 Inspection Results .............................................................. 7

2.5.3 CAU 424 Maintenance and Repairs ……………......................................... 9

2.5.4 CAU 424 Conclusions and Recommendations................................................ 9

2.6 CAU 426: CACTUS SPRING WASTE TRENCHES (TTR) ............................................... 9

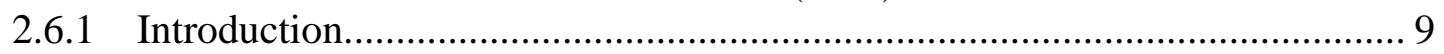

2.6.2 CAU 426 Inspection Results ....................................................................... 10

2.6.3 CAU 426 Maintenance and Repairs ............................................................. 10

2.6.4 CAU 426 Conclusions and Recommendations.............................................. 10

2.7 CAU 427: AREA 3 SEPTIC WASTE SySTEMS 2, 6 (TTR)......................................... 10

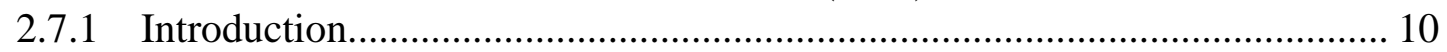

2.7.2 CAU 427 Inspection Results ...................................................................... 10

2.7.3 CAU 427 Maintenance and Repairs ............................................................ 11

2.7.4 CAU 427 Conclusions and Recommendations.............................................. 11

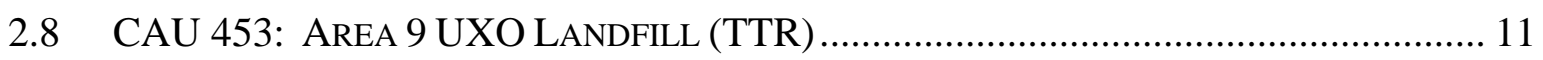

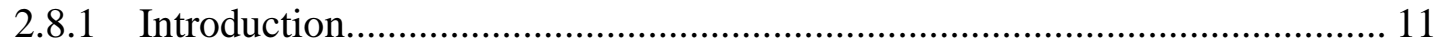

2.8.2 CAU 453 Inspection Results ....................................................................... 11

2.8.3 CAU 453 Maintenance and Repairs ............................................................... 12 


\section{TABLE OF CONTENTS (continued)}

2.8.4 CAU 453 Conclusions and Recommendations........................................... 12

2.9 CAU 487: THUNDERWELL SITE (TTR) ............................................................. 12

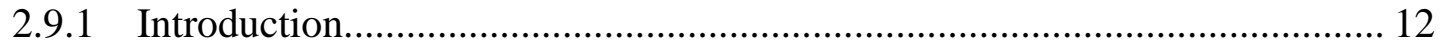

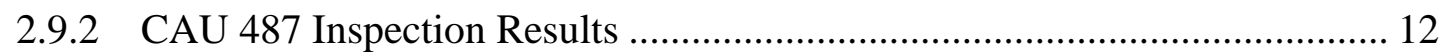

2.9.3 CAU 487 Maintenance and Repairs .......................................................... 13

2.9.4 CAU 487 Conclusions and Recommendations.......................................... 13

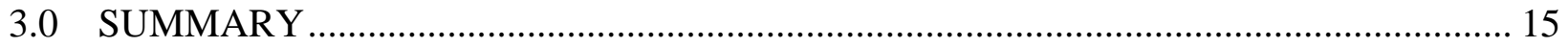

3.1 CAU 400: BomBLET PIT AND FIVE PoINTS LANDFILL (TTR) ................................. 15

3.2 CAU 404: ROLLER COASTER LAGOONS AND TRENCH (TTR) ................................ 15

3.3 CAU 407: Roller CoAster RAdSAFE AREA (TTR) …...................................... 15

3.4 CAU 423: Area 3 Underground Discharge Point, Building 0360 (TTR)....... 15

3.5 CAU 424: AREA 3 LANDFILl COMPLEXES (TTR) ............................................... 15

3.6 CAU 426: CACTUS SPRING WASTE TREnCHES (TTR) .......................................... 16

3.7 CAU 427: AREA 3 SEPTIC WASTE SYSTEMS 2, 6 (TTR) .......................................... 16

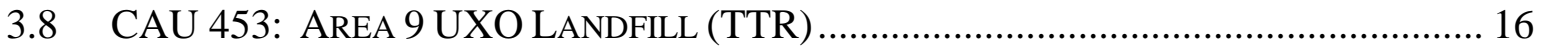

3.9 CAU 487: THUNDERWELL SITE (TTR) ................................................................ 16

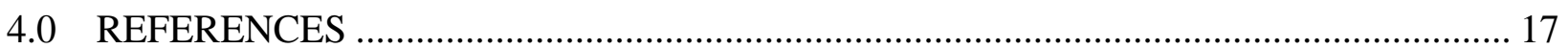

\section{ATTACHMENTS}

ATtACHMENT A. FiguRES

AtTACHMENT B. Post-Closure InsPection Plans

AtTACHMENT C. Post-Closure InsPection CHECKLists

ATTACHMENT D. FIELD NOTES

ATTACHMENT E. PHOTOGRAPHS

AtTACHMEnt F. Post-Closure Vegetation Monitoring Report

LIBRARY DISTRIBUTION LIST 


\section{ACRONYMS AND ABBREVIATIONS}

CADD

CAS

CAU

CR

$\mathrm{DOE} / \mathrm{NV}$

$\mathrm{m}$

$\mathrm{m}^{2}$

NDEP

NNSA/NSO

ROTC

TTR
Corrective Action Decision Document

Corrective Action Site

Corrective Action Unit

Closure Report

U.S. Department of Energy, Nevada Operations Office

meter(s)

square meter(s)

Nevada Division of Environmental Protection

U.S. Department of Energy, National Nuclear Security Administration

Nevada Site Office

Record of Technical Change

Tonopah Test Range 
Post-Closure Inspection Report - TTR

Revision: 0

Date: June 2006

THIS PAGE INTENTIONALLY LEFT BLANK 


\section{EXECUTIVE SUMMARY}

This report provides the results of the semi-annual post-closure inspections conducted at the closed Corrective Action Unit (CAU) sites located on the Tonopah Test Range (TTR), Nevada. This report covers calendar year 2005 and includes inspection and any repair activities completed at the following nine CAUs :

- CAU 400: Bomblet Pit and Five Points Landfill (TTR)

- CAU 404: Roller Coaster Lagoons and Trench (TTR)

- CAU 407: Roller Coaster RadSafe Area (TTR)

- CAU 423: Area 3 Underground Discharge Point, Building 0360 (TTR)

- CAU 424: Area 3 Landfill Complexes (TTR)

- CAU 426: Cactus Spring Waste Trenches (TTR)

- CAU 427: Area 3 Septic Waste Systems 2, 6 (TTR)

- CAU 453: Area 9 UXO Landfill (TTR)

- CAU 487: Thunderwell Site (TTR)

Post-closure site inspections were conducted on June 1-2, 2005, and November 15-16, 2005. All inspections were conducted according to the post-closure plans in the approved Closure Reports (CRs). The Post-Closure Inspection Plan for each CAU is included in Attachment B, with the exception of CAU 400. CAU 400 does not require post-closure inspections, but inspections of the vegetation and fencing are conducted as a best management practice. The inspection checklists for each site inspection are included in Attachment C; the field notes are included in Attachment D, and the site photographs are included in Attachment E. Vegetation monitoring of CAU 400, CAU 404, CAU 407, and CAU 426 was performed in June 2005, and the vegetation monitoring report is included in Attachment F.

Maintenance and/or repairs were performed at CAU 407, CAU 427, and CAU 487 in 2005.

\section{CAU 407}

During the November site inspection of CAU 407 a stand of barbed wire was temporarily reattached to fence posts, and a radiological warning sign reattached to the fence. Permanent site repairs are scheduled for the first quarter of 2006. Also, the CAU 407 cover was reseeded in December, 2004. To encourage the germination of seed and growth of vegetation, the CAU 407 cover was irrigated in February, March, and April, 2005.

\section{CAU 427}

Maintenance and repairs at CAU 427 were made on April 6-7, 2005, and consisted of locating and exposing the buried corner markers of five use-restricted areas. The surface location for each buried corner point was remarked with red cinder rock, and the leachfield boundaries marked with paint as needed. During the June site inspection additional red rock was placed over the buried corner markers to aid in locating the site markers in the future. The installation of permanent at-grade monuments for each corner of the use-restricted areas is scheduled for the first quarter of 2006. 


\section{CAU 487}

Maintenance and repairs conducted at CAU 487 were made on June 20, 2005, and included resetting the northwest corner monument at the A-8 anomaly area, as well as resetting the southeast, northeast, and northwest monuments at the A-17 anomaly area. Also, cracks on the top of the northwest and southeast monuments were repaired during this site inspection.

During the November 2005 site inspections several issues that require maintenance and repairs were noted. These included: subsidence of landfill cell covers at CAU 453; loose and downed fencing and warning signs at CAU 407; downed monuments at CAU 487. Repairs and maintenance are scheduled for the first quarter of 2006, within 90 working days of discovery.

At this time, the TTR post-closure site inspections should continue as scheduled. Any potential problem areas previously identified (e.g., areas of erosion, subsidence, etc.), should be monitored closely, and periodic vegetation surveys of the vegetated covers should continue. 


\subsection{INTRODUCTION}

\subsection{SCOPE AND OBJECTIVES}

This post-closure inspection report includes the results of inspections, maintenance and repair activities, and conclusions and recommendations for Calendar Year 2005 for nine Corrective Action Units (CAUs) located on the Tonopah Test Range (TTR), Nevada. The locations of the CAUs are shown in Figure 1 of Attachment A. The CAUs and Corrective Action Sites (CASs) covered in this report include the following:

- CAU 400: Bomblet Pit and Five Points Landfill (TTR)

- CAS TA-19-001-05PT: Ordnance Disposal Pit

- CAS TA-55-001-TAB2: Ordnance Disposal Pit

- CAU 404: Roller Coaster Lagoons and Trench (TTR)

- CAS TA-03-001-TARC: Roller Coaster Lagoons

- CAS TA-21-001-TARC: Roller Coaster N. Disposal Trench

- CAU 407: Roller Coaster RadSafe Area (TTR)

- CAS TA-23-001-TARC: Roller Coaster RadSafe Area

- CAU 423: Area 3 Underground Discharge Point, Building 0360 (TTR)

- CAS 03-02-002-0308: Underground Discharge Point

- CAU 424: Area 3 Landfill Complexes (TTR)

- CAS 03-08-001-A301: Landfill Cell A3-1

- CAS 03-08-002-A302: Landfill Cell A3-2

- CAS 03-08-002-A303: Landfill Cell A3-3

- CAS 03-08-002-A304: Landfill Cell A3-4

- CAS 03-08-002-A305: Landfill Cell A3-5

- CAS 03-08-002-A306: Landfill Cell A3-6

- CAS 03-08-002-A308: Landfill Cell A3-8

- CAU 426: Cactus Spring Waste Trenches (TTR)

- CAS RG-08-001-RGCS: Waste Trenches

- CAU 427: Area 3 Septic Waste Systems 2, 6 (TTR)

- CAS 03-05-002-SW02: Septic Waste System

- CAS 03-05-002-SW06: Septic Waste System

- CAU 453: Area 9 UXO Landfill (TTR)

- CAS 09-55-001-0952: Area 9 Landfill

- CAU 487: Thunderwell Site (TTR)

- CAS RG-26-001-RGRV: Thunderwell Site 
Post-closure inspections are conducted on a semi-annual basis (twice per calendar year) and consist of the following activities to evaluate and document the condition of the closed units. CAU-specific inspection requirements are included in Attachment B.

- Site inspections and photographs to verify site conditions and note variances from previous inspections

- Inspection of fencing, signs, monuments, and/or markers to determine if repairs and/or maintenance are needed

- Inspection of soil covers for indications of subsidence, erosion, unauthorized use, etc.

- Vegetation survey to quantify the condition of vegetative covers

- Subsidence survey to indicate any cover subsidence

- Preparation and submittal of an annual report

This Post-Closure Inspection Report includes the following sections:

- Section 1.0 - Introduction

- $\quad$ Section 2.0 - Post-Closure Inspections

- $\quad$ Section 3.0 - Summary

- Section 4.0 - References

- Attachment A. Figures

- Attachment B. Post-Closure Inspection Plans

- Attachment C. Post-Closure Inspection Checklists

- Attachment D. Field Notes

- Attachment E. Photographs

- Attachment F. Post-Closure Vegetation Monitoring Report

- Library Distribution List 


\subsection{POST-CLOSURE INSPECTIONS}

Post-closure site inspections of TTR CAUs for the annual period January 2005 through December 2005 were conducted on June 1-2, 2005, and November 15-16, 2005. Copies of Post-Closure Inspection Plans as previously published in the applicable Closure Report (CR) are included in Attachment B. Copies of the site inspection checklists are included in Attachment C, field notes are included in Attachment D, and site photographs are included in Attachment E.

\subsection{CAU 400: Bomblet Pit AND Five Points Landfill (TTR)}

\subsubsection{Introduction}

There are no specific post-closure requirements in the CR for CAU 400, Bomblet Pit and Five Points Landfill (TTR); however, when the sites were vegetated in 1997 under the Tonopah Test Range Closure Site Revegetation Plan (U.S. Department of Energy Nevada Operations Office [DOE/NV], 1997), fencing was installed at the Bomblet Pit (CAS TA-55-001-TAB2, Ordnance Disposal Pit) and the Five Points Landfill (CAS TA-19-001-05PT, Ordnance Disposal Pit). As stated in Section 3.5.4 of the revegetation plan (DOE/NV, 1997), fencing is required at both CASs for a minimum of five years in order to give the plants sufficient time to become established. Therefore, inspections are conducted at CAU 400 to document vegetation growth and inspect the integrity of the fences. Removal of site fencing may be proposed in the future once vegetation on the covers is well established. Vegetation monitoring of CAU 400 was conducted in June 2005, and the results are included in Attachment F.

\subsubsection{CAU 400 Inspection Results}

\subsubsection{First Semi-Annual Inspection}

\section{Bomblet Pit (CAS TA-55-001-TAB2, Ordnance Disposal Pit)}

The Bomblet Pit is presented in Figure 2 of Attachment A. The first inspection was conducted on June 1, 2005. The inspection indicated some minor animal burrows within the site and evidence of horses outside the fence. The cover vegetation was healthy and well established similar to the surrounding area outside the fence. The fence, signs, and cover were in good condition. No issues or concerns were noted that affected the integrity of the unit.

\section{Five Points Landfill (CAS TA-19-001-05PT, Ordnance Disposal Pit)}

The Five Points Landfill is presented in Figure 3 of Attachment A. The first inspection was conducted on June 1, 2005. All signs and fencing were in good condition. The reseeded cover area was in good condition with well established vegetation within the fence.

\subsubsection{Second Semi-Annual Inspection}

\section{Bomblet Pit (CAS TA-55-001-TAB2, Ordnance Disposal Pit)}

The second inspection was conducted on November 15, 2005. The site was in excellent condition. Vegetation remains healthy and well established. The fence, signs, and cover were in good condition. The U.S. Department of Energy, National Nuclear Security Administration Nevada Site Office (NNSA/NSO) and Nevada Division of Environmental Protection (NDEP) proposed removing the fence following the 2006 inspection if the vegetation remains healthy. 
Five Points Landfill (CAS TA-19-001-05PT, Ordnance Disposal Pit)

The second inspection was conducted on November 15, 2005. All signs and fencing were in good condition. Vegetation appeared healthy, but sparse in the central part of the cover from revegetation done in November, 2004. A biologist will evaluate the health of the vegetation in 2006.

\subsubsection{CAU 400 Maintenance and Repairs}

No maintenance or repairs were conducted at CAU 400 during 2005.

\subsubsection{CAU 400 Conclusions and Recommendations}

Both the Bomblet Pit and the Five Points Landfill are in excellent condition. As stated in the revegetation plan (DOE/NV, 1997), the sites are to be fenced for a minimum of five years in order to give the vegetation sufficient time to become established. Based on the results of the 2005 inspections and the Post-Closure Vegetation Monitoring Report (Attachment F), it has been determined that the vegetation is not currently sufficiently established to remove the fences. However, during the November 15 inspection, the NNSA/NSO and NDEP proposed removing the fencing at both sites if after the 2006 inspections, the vegetation has matured to the same extent as the surrounding undisturbed areas. Until this is determined, both sites will remain fenced and semi-annual site inspections continued.

\subsection{CAU 404: ROLLER COASTER LAgOONS AND TRENCH (TTR)}

\subsubsection{Introduction}

CAU 404, Roller Coaster Lagoons and Trench (TTR), consists of two CASs (CAS TA-03-001-TARC, Roller Coaster Lagoons; and CAS TA-21-001-TARC, Roller Coaster N. Disposal Trench). Post-closure requirements are described in the CR for CAU 404 (DOE/NV, 1998a), which was approved by the NDEP on May 18, 1999.

Site inspections were conducted on June 1, 2005, and November 15, 2005. A diagram showing the site location and configuration is presented as Figure 4 of Attachment A. The site inspections were conducted according to the CAU 404 Post-Closure Inspection Plan (Attachment B). In addition to site inspections, vegetation monitoring of the site was conducted in June 2005, and the results are included in Attachment F.

\subsubsection{CAU 404 Inspection Results}

\subsubsection{First Semi-Annual Inspection}

The first inspection was conducted on June 1, 2005. This site was in good condition. No damage was noted to the fencing, signs, or cover. The vegetation was healthy and well established. Some small animal burrows were noted, but no maintenance or repairs were needed.

\subsubsection{Second Semi-Annual Inspection}

The second inspection was completed on November 15, 2005. The unit was in good condition. Several small animal burrows were present along the fence line and were backfilled by hand during the site inspection. The fence was in good condition, and all warning signs were intact 
and legible. No erosion, subsidence, or cracking of the cover was observed and the vegetation on the cover was healthy.

\subsubsection{CAU 404 Maintenance and Repairs}

No maintenance or repairs were conducted at CAU 404 during 2005.

\subsubsection{CAU 404 Conclusions and Recommendations}

The cover, fence, posted warning signs, and gates are all in good condition. The site inspections should continue as scheduled.

\subsection{CAU 407: ROLlER COASTER RADSAFE AREA (TTR)}

\subsubsection{Introduction}

CAU 407, Roller Coaster RadSafe Area (TTR), consists of one CAS (CAS TA-23-001-TARC, Roller Coaster RadSafe Area). The post-closure requirements for CAU 407 are described in the CR (DOE/NV, 2001a). Revision 1 of the CR was approved by the NDEP on February 22, 2002. Section 5.2 of the CR calls for site inspections to be conducted within the first six months following completion of cover construction. Following the first six months, site inspections are to be conducted twice yearly for the next two years. Previous inspections have noted erosion rills on the cover margins, and subsequent maintenance was completed to repair the rills and help prevent future erosion.

Site inspections were conducted on June 1, 2005, and November 15, 2005. A diagram showing the site location and configuration is presented in Figure 5 of Attachment A. The site inspections were conducted according to the CAU 407 Post-Closure Inspection Plan (Attachment B). In addition to site inspections, vegetation monitoring of the site was conducted in June 2005, and the results are included in Attachment F.

\subsubsection{CAU 407 Inspection Results}

\subsubsection{First Semi-Annual Inspection}

The first inspection was conducted on June 1, 2005. The inspection indicated the cover is in good condition. New vegetation was present on the cover and has become established. Irrigation will continue until it is determined that the vegetation is self sufficient by a biologist. Some small animal burrows were present within the fence, but are not a problem at this time. The fence and warning signs were intact and in good condition.

\subsubsection{Second Semi-Annual Inspection}

The second inspection was conducted on November 15, 2005. Small animal burrows were present within the fence, but do not affect the integrity of the cover. No erosion cracks or subsidence of the cover was observed during the inspection. The top strand of the barbed-wire fence was broken on the south side of the site, extending approximately $100 \mathrm{ft}$ from the gate. Also, a radiological warning sign was loose due to high winds. The wire strand and warning sign were temporarily reattached during the inspection. 


\subsubsection{CAU 407 Maintenance and Repairs}

During the November 2005 inspection of CAU 407, a loose strand of barbed wire and a radiological warning sign were temporarily reattached. Re-tensioning the barbed wire fence and permanently reattaching the warning sign is scheduled for the first quarter of 2006. Also, the cover was reseeded in December 2004 and was irrigated in February, March, and April, 2005, to supplement natural precipitation to encourage seed germination.

\subsubsection{CAU 407 Conclusions and Recommendations}

This site is in good condition. The site inspections should continue as scheduled, and the health of the vegetation and integrity of the cover monitored, until the site has stabilized.

\subsection{CAU 423: Area 3 Underground Discharge Point, BuILding 0360 (TTR)}

\subsubsection{Introduction}

CAU 423, Area 3 Underground Discharge Point, Building 0360, consists of one CAS (CAS 03-02-002-0308, Underground Discharge Point). CAU 423 was closed in place, with one warning sign and one at-grade monument installed, as detailed in the CR (DOE/NV, 1999a). The CR did not require post-closure inspections. A Record of Technical Change (ROTC) to the CR (NNSA/NSO, 2005a) specifying the post-closure inspection requirements was approved by the NDEP on June 6, 2005 (Attachment B). Site inspections were conducted on June 2, 2005, and November 16, 2005. A diagram showing the site location and configuration is presented in Figure 6 of Attachment A.

\subsubsection{CAU 423 Inspection Results}

\subsubsection{First Semi-Annual Inspection}

The first inspection was conducted on June 2, 2005. The warning sign and at-grade monument are in excellent condition. NNSA has requested that the piping running to the underground discharge point be removed. The work is scheduled for the second half of 2006.

\subsubsection{Second Semi-Annual Inspection}

The second inspection was conducted on November 16, 2005. The site was in excellent condition. The warning sign and at-grade monument are in good condition.

\subsubsection{CAU 423 Maintenance and Repairs}

No maintenance or repairs at CAU 423 were conducted in 2005.

\subsubsection{CAU 423 Conclusions and Recommendations}

The warning sign and at-grade monument are in good condition. The site inspections should continue as scheduled. 


\subsection{CAU 424: Area 3 LANDFill Complexes (TTR)}

\subsubsection{Introduction}

CAU 424, Area 3 Landfill Complexes (TTR), consists of eight CASs. Seven landfill cells (CAS 03-08-001-A301, Landfill Cell A3-1; CAS 03-08-002-A302, Landfill Cell A3-2; CAS 03-08-002-A303, Landfill Cell A3-3; CAS 03-08-002-A304, Landfill Cell A3-4; CAS 03-08-002-A305, Landfill Cell A3-5; CAS 03-08-002-A306, Landfill Cell A3-6; and CAS 03-08-002-A308, Landfill Cell A3-8) were closed with soil covers and require post-closure inspections. CAS 03-08-002-A307, Landfill Cell A3-7, was not used as a landfill site and was closed without taking any corrective action. CAU 424 closure activities included removing small volumes of soil containing petroleum hydrocarbons, repairing cell covers that were cracked and/or had subsided, and installing above-grade and at-grade monuments to mark the corners of the landfill cells. Post-closure requirements for CAU 424 are detailed in the CR, which was approved by the NDEP in July 1999 (DOE/NV, 1999b).

Site inspections of the seven CASs were conducted on June 1, 2005, and November 15, 2005. A diagram showing the landfill locations is presented in Figure 7 of Attachment A. The site inspections were conducted according to the CAU 424 Post-Closure Inspection Plan (Attachment B).

\subsubsection{CAU 424 Inspection Results}

\subsubsection{First Semi-Annual Inspection}

The first site inspection was conducted on June 1, 2005.

Landfill Cell A3-1 (CAS 03-08-001-A301)

Landfill Cell A3-1 is located at the north end of CAU 424 and is the largest of the landfill cells. The cover and seven above-grade concrete monuments that demarcate the landfill cell were examined. All signs, survey markers, and monuments were in good condition. Vegetation is established throughout the site and no cracking, erosion or subsidence of the cover was observed. No issues were noted with the repairs made in 2004.

Landfill Cell A3-2 (CAS 03-08-002-A302) Landfill Cell A3-2 is located due south of Landfill Cell A3-1. The overall condition of the unit was good. All four above-grade monuments and the landfill cover were examined and found to be in good condition. All signs and brass survey markers were legible and intact. No signs of erosion, subsidence, or unauthorized use were observed.

Landfill Cell A3-3 (CAS 03-08-002-A303)

Landfill Cell A3-3 straddles the western fence of the TTR Area 3 Compound, with the portions of the landfill outside the fence marked by three above-grade monuments, and the portion inside the fence marked by three at-grade monuments. The overall condition of the site was good. All six monuments were located and inspected. All monuments, brass survey markers, and warning signs were in good condition. No subsidence, cracking, or erosion was observed. Sparse vegetation was present near the above-grade monuments, but none was present near the at-grade monuments. No issues or concerns were observed for this site. 
Landfill Cell A3-4 (CAS 03-08-002-A304)

Landfill Cell A3-4 is located south of Dykes Drive at the south end of the CAU. Five above-grade monuments and one at-grade brass survey marker were located and inspected. All monuments, the brass survey marker, and warning signs were in good condition. Repairs made to the cover at the end of the 2004 are intact and no subsidence or low areas present. Vegetation is beginning to become established throughout the site.

Landfill Cell A3-5 (CAS 03-08-002-A305)

Landfill Cell A3-5 is located west of Moody Avenue inside a fenced area in Area 10 south of the Air Force First-Aid Station. All four above-grade monuments and attached warning signs and brass survey markers were located and found to be in excellent condition. No evidence of subsidence, cracking, or erosion was observed, and sparse vegetation is present. The overall condition of the site is excellent.

Landfill Cell A3-6 (CAS 03-08-002-A306)

Landfill Cell A3-6 is located immediately west and outside of the fence of the TTR Area 3 Compound. All four above-grade monuments and attached warning signs and brass survey markers were located and found to be in good condition. The overall condition of the landfill cover was good. No evidence of subsidence, cracking, or erosion was observed. Some small animal burrows were found, but do not affect the integrity of the cover.

Landfill Cell A3-8 (CAS 03-08-002-A308)

Landfill Cell A3-8 is located southwest of the Area 3 Compound in the box car storage yard. Three of the four at-grade brass markers were located and determined to be in good condition. The southwest corner monument was not located due to its location in a posted radioactive materials area and the presence of surface debris. There was no indication that the debris was impacting the condition of the monument. The monument will be inspected in future inspections when the surface debris is removed. No erosion, subsidence, or unauthorized use was observed at the site. The overall condition of the cover was good.

\subsubsection{Second Semi-Annual Inspection}

The second inspection was conducted on November 15, 2005.

Landfill Cell A3-1 (CAS 03-08-001-A301)

All signs and survey markers were intact, and legible. The seven above-grade monuments were in good condition. No cracking, erosion, or unauthorized use of the cover was observed. The overall condition of the site was good.

Landfill Cell A3-2 (CAS 03-08-002-A302)

The four above-grade monuments were located and found to be in good condition. The signs and brass survey markers were also in good condition. Vegetation was widely dispersed on the cover. The overall condition of the unit was good.

Landfill Cell A3-3 (CAS 03-08-002-A303)

The three above-grade monuments and three at-grade monuments were located and inspected. All monuments, brass survey markers, and signs were in good condition. No subsidence or erosion was observed. No issues or concerns were observed for this site. 
Landfill Cell A3-4 (CAS 03-08-002-A304)

The five above-grade monuments and one at-grade brass survey marker were located and inspected. All monuments, the brass survey marker, and warning signs were in good condition. The cover showed no erosion, subsidence, or unauthorized use and the vegetation was healthy and well established.

\section{Landfill Cell A3-5 (CAS 03-08-002-A305)}

The four above-grade monuments were located and inspected. The monuments, attached warning signs, and survey markers were in good condition. The vegetation growing on the cover was healthy. No evidence of subsidence, cracking, or erosion was observed. The overall condition of the landfill cover was good.

Landfill Cell A3-6 (CAS 03-08-002-A306)

The four above-grade monuments were located and inspected. The monuments and survey markers were in good condition. The warning signs were intact and legible. No evidence of subsidence, cracking, or erosion was observed. The overall condition of the site was good.

Landfill Cell A3-8 (CAS 03-08-002-A308)

Three of the four at-grade monuments were located and found to be in good condition. The southwest corner monument is located in a posted and fenced radioactive materials area where it can not be visually inspected. The corner monument is also covered by debris, but does not appear to be impacted by the debris, and there is no sign of ground disturbance. No erosion, subsidence, or cracking was observed. The overall condition of the site was good.

\subsubsection{CAU 424 Maintenance and Repairs}

No maintenance or repairs at CAU 424 were conducted in 2005.

\subsubsection{CAU 424 Conclusions and Recommendations}

All seven CASs in CAU 424 are in good condition. The site inspections should continue as scheduled monitoring the landfill soil covers, markers, and warning signs.

\subsection{CAU 426: CACtUS SPRing WASTE TRENCHES (TTR)}

\subsubsection{Introduction}

CAU 426, Cactus Spring Waste Trenches (TTR), consists of one CAS (CAS RG-08-001-RGCS, Waste Trenches). The post-closure requirements are described in the CR for CAU 426 (DOE/NV, 1998b), which was approved by the NDEP on May 13, 1999.

Site inspections were conducted on June 2, 2005, and November 15, 2005. A diagram showing the site location and configuration is presented in Figure 8 of Attachment A. The site inspections were conducted according to the CAU 426 Post-Closure Inspection Plan (Attachment B). In addition to site inspections, vegetation monitoring of the site was conducted in June 2005, and the results are included in Attachment F. 


\subsubsection{CAU 426 Inspection Results}

\subsubsection{First Semi-Annual Inspection}

The first inspection was conducted on June 2, 2005. The fence perimeter was walked and the site was found to be in good condition. There was no damage to the perimeter fencing or signs. The signs were intact and legible. No erosion, subsidence, or unauthorized use was observed. Vegetation was well established and healthy throughout the site. Some small animal burrows were noted along the fence and at the toe of the cover, but do not affect the integrity of the cover. No site maintenance or repairs are needed.

\subsubsection{Second Semi-Annual Inspection}

The second inspection was conducted on November 15, 2005. The overall condition of the unit was good. The fence was in excellent condition, and the wire mesh along the base of the fence was intact. Several small animal burrows were noted around the fence, but they do not affect the integrity of the unit. The signs were legible and in good condition. The vegetation was healthy and has stabilized the soil cover. No subsidence, cracking, or unauthorized use was observed.

\subsubsection{CAU 426 Maintenance and Repairs}

No maintenance or repairs were conducted at CAU 426 during 2005.

\subsubsection{CAU 426 Conclusions and Recommendations}

The cover, fence, and posted warning signs are all in excellent condition. The site inspections should continue as scheduled.

\subsection{CAU 427: AREA 3 SePtic WAste Systems 2, 6 (TTR)}

\subsubsection{Introduction}

CAU 427, Area 3 Septic Waste Systems 2, 6 (TTR), consists of two CASs (CAS 03-05-002-SW02, Septic Waste System; and CAS 03-05-002-SW06, Septic Waste System). The closed leachfields are located in the TTR Area 3 compound in a high traffic area. For this reason, the leachfield corners are marked by subsurface metal markers each covered with red cinder rock to the ground surface. The red rock aids in visually locating the markers during site inspections. Post-closure requirements for CAU 427 are detailed in the CR for CAU 427 (DOE/NV, 1999c), which was approved by the NDEP on August 27, 1999.

Site inspections were conducted on June 2, 2005, and November 16, 2005. A diagram showing the site location and configuration is presented in Figure 9 of Attachment A. The site inspections were conducted according to the CAU 4227 Post-Closure Inspection Plan (Attachment B).

\subsubsection{CAU 427 Inspection Results}

\subsubsection{First Semi-Annual Inspection}

The first inspection was conducted on June 2, 2005. All 21 subsurface metal markers were located at the corners of Leachfield A (four markers), Leachfield B (four markers), Abandoned Leachfield (four markers), Pre-1965 Leachfield (four markers), and Septic Tank 33-5 (five markers). The five warning signs were intact, in place, and legible. The site was in good condition, and no maintenance or repairs were needed. 


\subsubsection{Second Semi-Annual Inspection}

The second inspection was conducted on November 16, 2005. All 21 subsurface metal markers were located at the corners of Leachfield A (four markers), Leachfield B (four markers), Abandoned Leachfield (four markers), Pre-1965 Leachfield (four markers), and Septic Tank 33-5 (five markers). The five warning signs were located and found to be in good condition. No vegetation was present, and no evidence of subsidence, erosion, or intrusive activities into the use restricted areas was noted. The overall condition of the site was good.

\subsubsection{CAU 427 Maintenance and Repairs}

On April 6-7, 2005, the 21 subsurface corner locations for the five use-restricted areas (4 leachfields and 1 removed septic tank) were located and the overburden removed to expose the markers. Each shallow excavation was then backfilled with red cinder rock to the ground surface to aid in visually locating the markers during future inspections. See field notes for work in Attachment C

\subsubsection{CAU 427 Conclusions and Recommendations}

Overall the site was in good condition and site inspections should continue as scheduled. During the second inspection NNSA/NSO and NDEP requested that the subsurface corner markers be replaced with at-grade or slightly sub-grade monuments in 2006 to better mark the use restricted areas. This work is scheduled for the first half of 2006.

\subsection{CAU 453: AREA 9 UXO LANDFILL (TTR)}

\subsubsection{Introduction}

CAU 453, Area 9 UXO Landfill (TTR), consists of one CAS (CAS 09-55-001-0952, Area 9 Landfill). Post-closure requirements for CAU 453 are described in the CR for CAU 453 (DOE/NV, 1999d), which was approved by the NDEP on September 10, 1999.

Site inspections were conducted on June 2, 2005, and November 16, 2005. A diagram showing the site location and configuration is presented in Figure 10 of Attachment A. The site inspections were conducted according to the CAU 453 Post-Closure Inspection Plan (Attachment B).

\subsubsection{CAU 453 Inspection Results}

\subsubsection{First Semi-Annual Inspection}

The first inspection was conducted on June 2, 2005. The fence, signs, 16 above-ground monuments, and covers were all in excellent condition. Some small animal burrows were noted during the inspection but do not affect the integrity of the covers.

\subsubsection{Second Semi-Annual Inspection}

The second inspection was conducted on November 16, 2005. The fence, signs, and 16 above-grade monuments were in good condition. There was no lock present on the gate during the time of the inspection so a new lock will be installed. Significant subsidence was observed on the east end of cell A9-3, and one small but deep area of subsidence was noted on cell A9-1 (Figure10 of Attachment A). Several areas of subsidence are approximately one to three feet 
long; however, there is one large area approximately 70 by 30 feet long. These subsidence areas are shown in photographs 41 and 42 in Attachment E.

\subsubsection{CAU 453 Maintenance and Repairs}

TTR Security placed a new lock on the CAU 453 gate in 2005.

\subsubsection{CAU 453 Conclusions and Recommendations}

The fence, posted warning signs, and monuments are all in good condition. The site inspections should continue as scheduled. The areas of subsidence found during the November inspection are scheduled for repair in the beginning of 2006.

\subsection{CAU 487: THUNDERWELL SITE (TTR)}

\subsubsection{Introduction}

CAU 487, Thunderwell Site (TTR) consists of one CAS (CAS RG-26-001-RGRV, Thunderwell Site). The Corrective Action Decision Document (CADD)/CR was approved by the NDEP on December 17, 2001 (DOE/NV, 2001b). Buried waste and debris were present at the site but no contamination was found. Land-Use Restrictions were implemented at the site as explained in the CADD/CR, but no post-closure inspections were proposed. Two separate land-Use Restrictions were implemented to address areas associated with subsurface geophysical anomalies (anomalies A-8 and A-17). Concrete monuments were installed at both locations of buried waste. A ROTC to modify the CADD/CR to include post-closure inspections and Use Restrictions information was approved by the NDEP on July 30, 2004 (NNSA/NSO, 2004a).

Site inspections were conducted on June 2, 2005, and November 16, 2005. A diagram showing the site location and configuration is presented in Figure 11 of Attachment A.

\subsubsection{CAU 487 Inspection Results}

\subsubsection{First Semi-Annual Inspection}

The first inspection was conducted on June 2, 2005. All warning signs were in place, intact, and legible. At anomaly A-8 the northwest corner monument was knocked down and lying on the ground. At anomaly A-17 the northwest, northeast, and southeast monuments were also knocked down. Hoof prints and horse droppings located at the northeast monument indicated that wild horses were responsible for upending the monuments. Cracks were found near the tops of the northwest and southeast monuments. The monuments are scheduled to be repaired and reinstalled before the November, 2005 site inspection.

\subsubsection{Second Semi-Annual Inspection}

The second inspection was conducted on November 16, 2005. As with the first inspection, one monument was knocked down at anomaly A-8 and three monuments were knocked down at anomaly A-17, and, the tops of two monuments were cracked. Again there were hoof prints and horse droppings located near the monuments indicating that wild horses had caused the damage. All warning signs were legible and in good condition. 


\subsubsection{CAU 487 Maintenance and Repairs}

On June 20, 2005, the four above-grade concrete monuments at anomaly A-8 and one monument at A-17 were reinstalled and the tops of the monuments repaired. The repairs required as a result of the second site inspection are scheduled for early in 2006.

\subsubsection{CAU 487 Conclusions and Recommendations}

The required repairs to the monuments following the second site inspection are scheduled for early 2006. To prevent future damage the base of the monuments will be set approximately 1.5 foot below ground surface. Site inspections should continue as scheduled. 
Post-Closure Inspection Report - TTR

Revision: 0

Date: June 2006

THIS PAGE INTENTIONALL LEFT BLANK 


\subsection{SUMMARY}

\subsection{CAU 400: Bomblet Pit and Five Points Landfill (TTR)}

Site inspections at CAS TA-55-001-TAB2, Ordnance Disposal Pit (Bomblet Pit) indicated that the site is in excellent condition. All fencing, signs, and vegetation are in good condition. NNSA and NDEP recommended removing the fence after the 2006 inspections if the vegetation has matured to the same extent as the surrounding areas.

Site inspections at CAS TA-19-001-05PT, Ordnance Disposal Pit (Five Points Landfill) indicated vegetation is establishing well from the revegetation in 2004 . No maintenance or repairs were conducted for CAU 400 during 2005. The sites are in good condition and site inspections should continue as scheduled.

\subsection{CAU 404: ROLLER COASTER LAgOONS AND TRENCH (TTR)}

Both site inspections indicated that the site was in good condition, and there was no damage noted to the fencing, signs, or cover. Some minor animal burrowing was noted, but no maintenance or repairs were needed. The site was in good condition and site inspections should continue as scheduled.

\subsection{CAU 407: Roller CoAster RAdSAFe AREA (TTR)}

Site inspections indicated that the cover and warning signs were in good condition. The cover was irrigated in February, March, and April 2005 and will continue until determined to be no longer necessary by a biologist. Small animal burrows were observed outside the fence, but do not affect the integrity of the unit. Temporary repairs to the barbed wire fence and a warning sign were made during the November 2005 site inspection. Permanent repairs of the fence and sign are scheduled for early 2006. The site was in good condition and site inspections should continue as scheduled.

\subsection{CAU 423: Area 3 Underground Discharge Point, Building 0360 (TTR)}

Site inspections indicated that the unit was in good condition. The warning sign and at-grade monument were located and found to be in good condition. No maintenance or repairs at CAU 423 were done in 2004. The site was in good condition and site inspections should continue as scheduled.

\subsection{CAU 424: AREA 3 LANDFill CompleXes (TTR)}

Site inspections indicated that all signs and survey markers were in good condition. No subsidence, cracking, or unauthorized use of the cover was observed. All monuments were located and found to be in good condition. The site is in excellent condition and inspections should continue as scheduled. 


\subsection{CAU 426: CActus SPRing WASTE TREnChes (TTR)}

The site inspections indicated that the site was in good condition. All signs were intact, in place, and legible, the fence and cover are in good condition. Some small animal burrows were noted near the fence and the toe of the cover, but do not affect the integrity of the unit. The site was in good condition and site inspections should continue as scheduled.

\subsection{CAU 427: Area 3 SePtic Waste Systems 2, 6 (TTR)}

During April 2005, maintenance work at CAU 427 was performed and consisted of exposing the buried corner points and adding red cinder rocks to help locate the markers in the future. NNSA/NSO and NDEP requested that the corner subsurface plates be replaced with at-grade or slightly sub-grade monuments in 2006. The five use restriction warning signs were intact and legible. Overall the site was in good condition and site inspections should continue as scheduled.

\subsection{CAU 453: AREA 9 UXO LANDFILL (TTR)}

Site inspections indicated that the fence, signs, and monuments were in good condition. During the second site inspection several areas of cover subsidence were identified at A9-1 and A9-3. A9-1 only had small areas of subsidence, while A9-3 had significantly greater areas of subsidence. Repairs will be conducted in the beginning of 2006. Site inspections should continue as scheduled,

\subsection{CAU 487: THUNDERWELL SITE (TTR)}

During the first site inspection four monuments were reported knocked down and damaged. These monuments were repaired and reinstalled on June 20, 2005. During the second site inspection, again, four monuments were observed to be over turned and damaged. These monuments are scheduled to be repaired and reinstalled below grade early in 2006. Site inspections should continue as scheduled. 


\subsection{REFERENCES}

DOE/NV, see U.S. Department of Energy, Nevada Operations Office.

NNSA/NSO, see U.S. Department of Energy, National Nuclear Security Administration Nevada Site Office.

U.S. Department of Energy, Nevada Operations Office. 1997. Tonopah Test Range Closure Sites Revegetation Plan, DOE/NV/11718-115 UC-702. Las Vegas, NV.

U.S. Department of Energy, Nevada Operations Office. 1998a. Closure Report for Corrective Action Unit 404: Roller Coaster Sewage Lagoons and North Disposal Trench, Tonopah Test Range, Nevada, DOE/NV/11718-187 UC-702. Las Vegas, NV.

U.S. Department of Energy, Nevada Operations Office. 1998b. Closure Report for Corrective Action Unit 426: Cactus Spring Waste Trenches, Tonopah Test Range, Nevada, DOE/NV/11718-226 UC-702. Las Vegas, NV.

U.S. Department of Energy, Nevada Operations Office. 1999a. Closure Report for Corrective Action Unit 423: Area 3 Building 03-60 Underground Discharge Point, Tonopah Test Range, Nevada, DOE/NV/11718--319. Las Vegas, NV.

U.S. Department of Energy, Nevada Operations Office. 1999b. Closure Report for Corrective Action Unit 424: Area 3 Landfill Complexes, Tonopah Test Range, Nevada, DOE/NV/11718--283. Las Vegas, NV.

U.S. Department of Energy, Nevada Operations Office. 1999c. Closure Report for Corrective Action Unit 427: Area 3 Septic Waste Systems 2 and 6, Tonopah Test Range, Nevada, DOE/NV/11718--326. Las Vegas, NV.

U.S. Department of Energy, Nevada Operations Office. 1999d. Closure Report for Corrective Action Unit 453: Area 9 UXO Landfill, Tonopah Test Range, Nevada, DOE/NV/11718--284. Las Vegas, NV.

U.S. Department of Energy, Nevada Operations Office. 2001a. Closure Report for Corrective Action Unit 407: Roller Coaster RadSafe Area, Tonopah Test Range, Nevada, DOE/NV/11718--694-REV1. Las Vegas, NV.

U.S. Department of Energy, Nevada Operations Office. 2001b. Corrective Action Decision Documents/Closure Report for Corrective Action Unit 487: Thunderwell Site, Tonopah Test Range, Nevada, DOE/NV/11718--761. Las Vegas, NV.

U.S. Department of Energy, National Nuclear Security Administration Nevada Site Office. 2004a. Record of Technical Change No. 2 for the Final Corrective Action Decision Document/Closure Report for Corrective Action Unit 487: Thunderwell Site, Tonopah Test Range, Nevada, Revision 0, November 2001. Las Vegas, NV. 
U.S. Department of Energy, National Nuclear Security Administration Nevada Site Office. 2005a. Record of Technical Change No. CR-1 for the Final Closure Report for Corrective Action Unit 423: Area 3 Building 0360 Underground Discharge Point, Tonopah Test Range, Nevada, Revision 0, July 1999. Las Vegas, NV. 
Post-Closure Inspection Report - TTR

Revision: 0

Date: June 2006

\section{AtTachment A.}

\section{FIGURES}


Post-Closure Inspection Report - TTR

Revision: 0

Date: June 2006

THIS PAGE INTENTIONALLY LEFT BLANK 


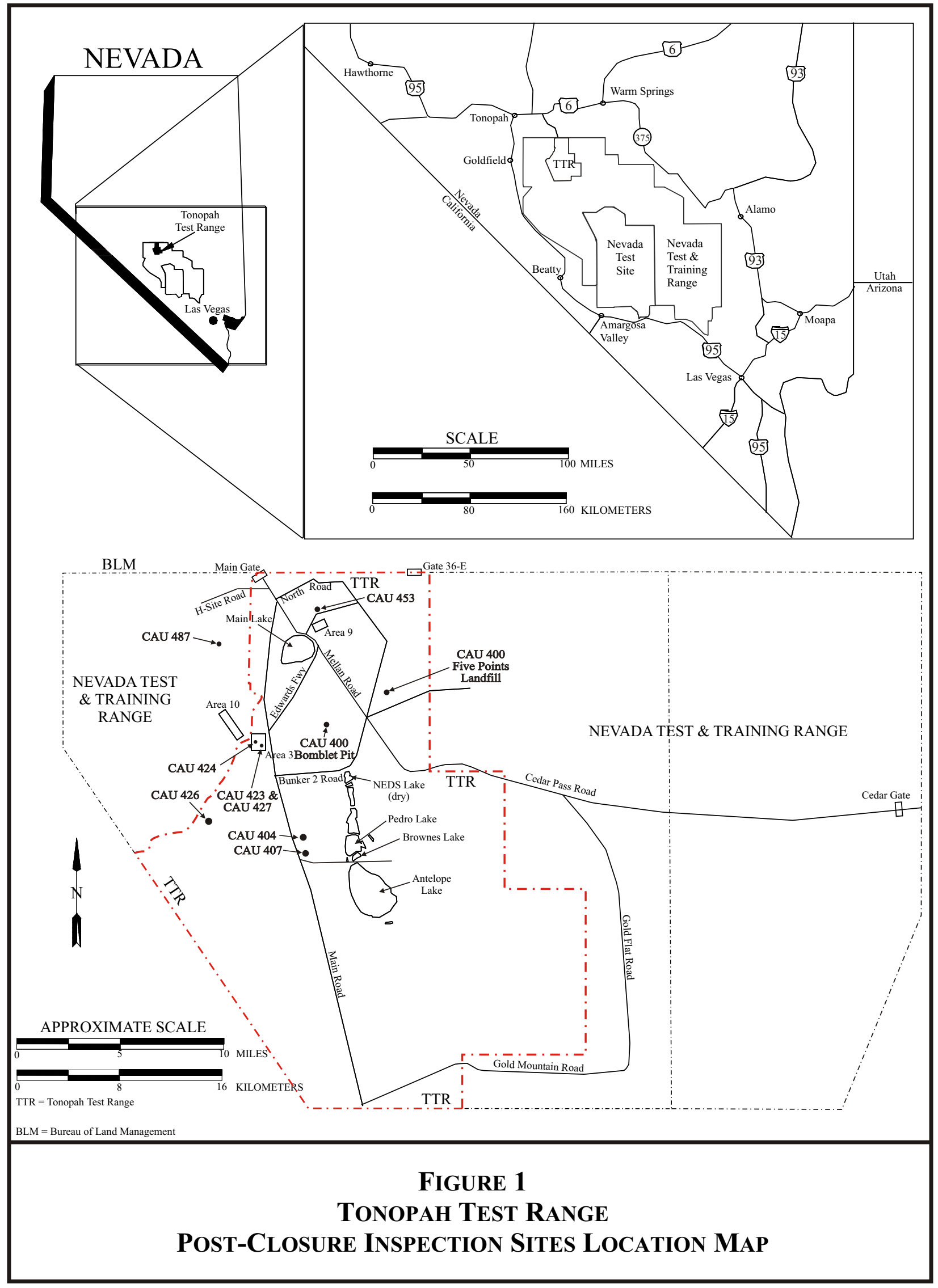




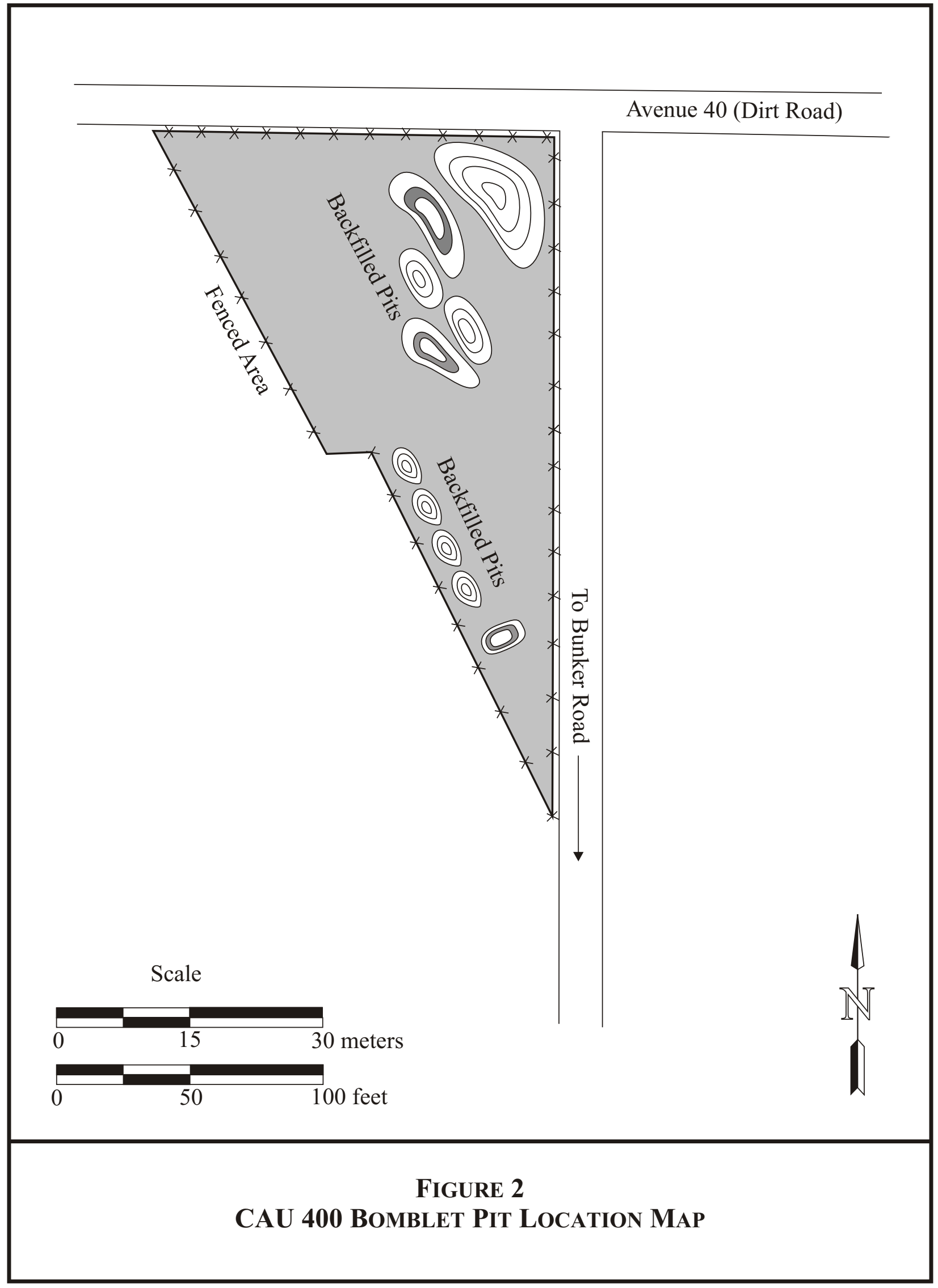




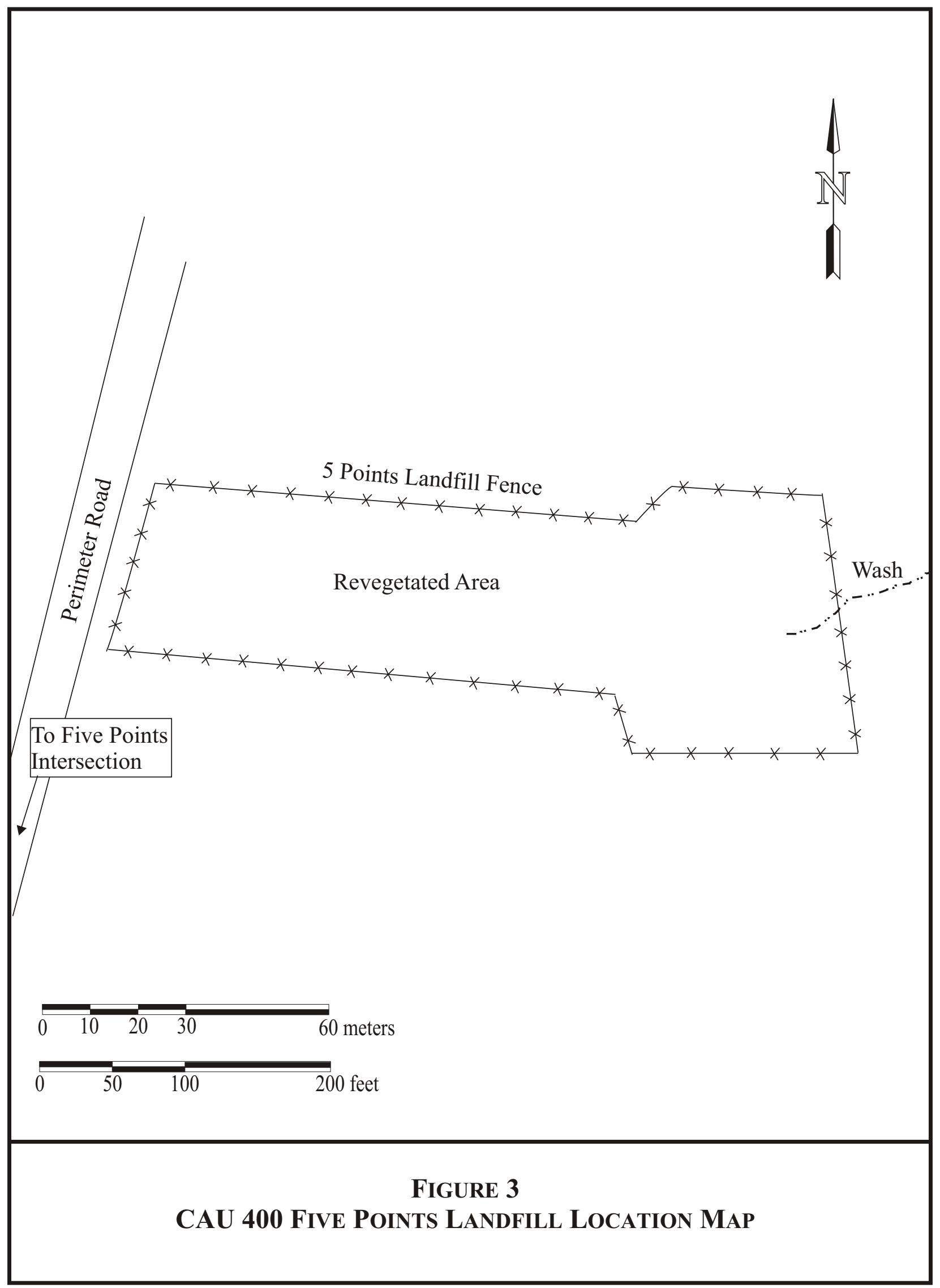




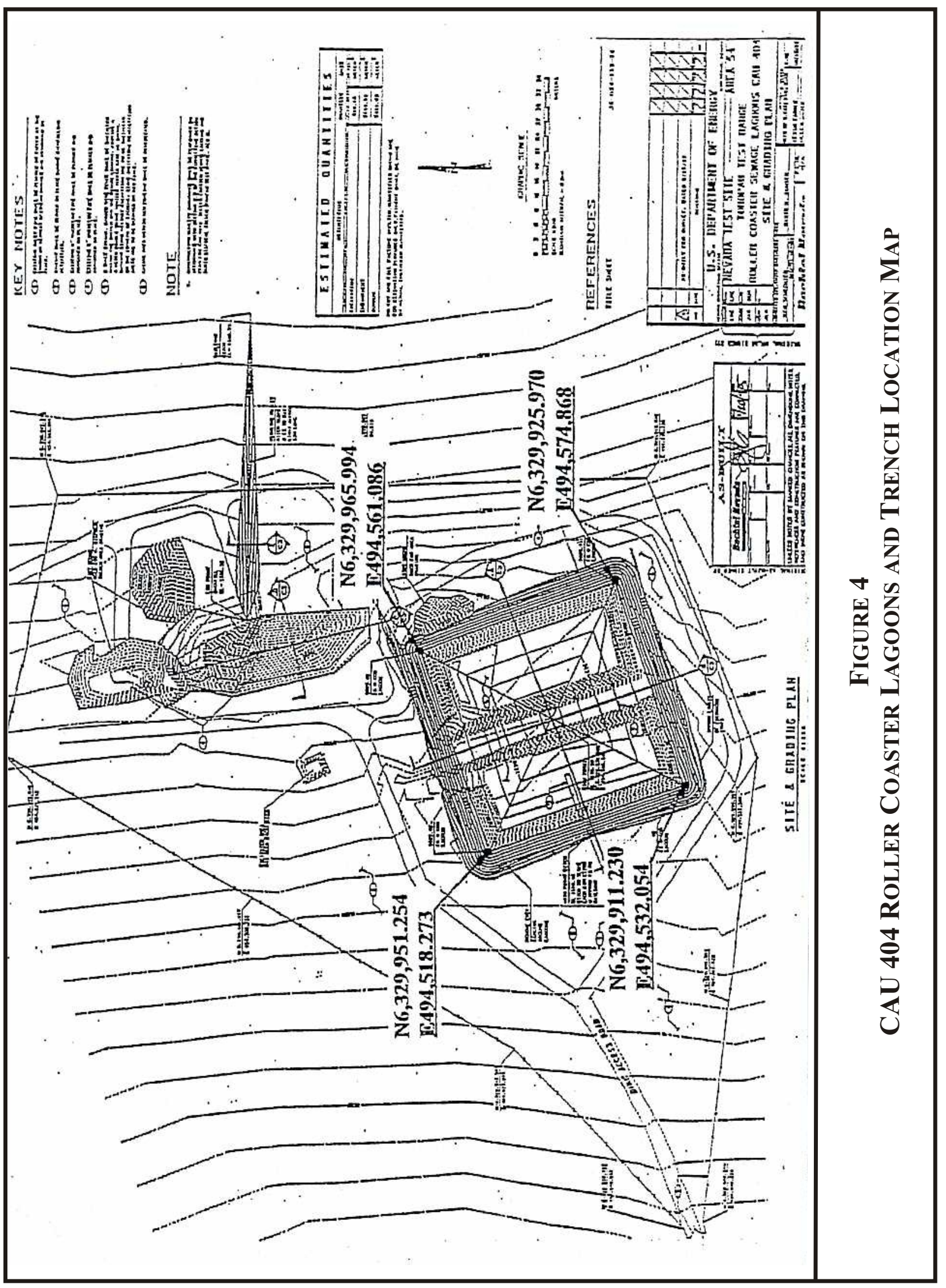




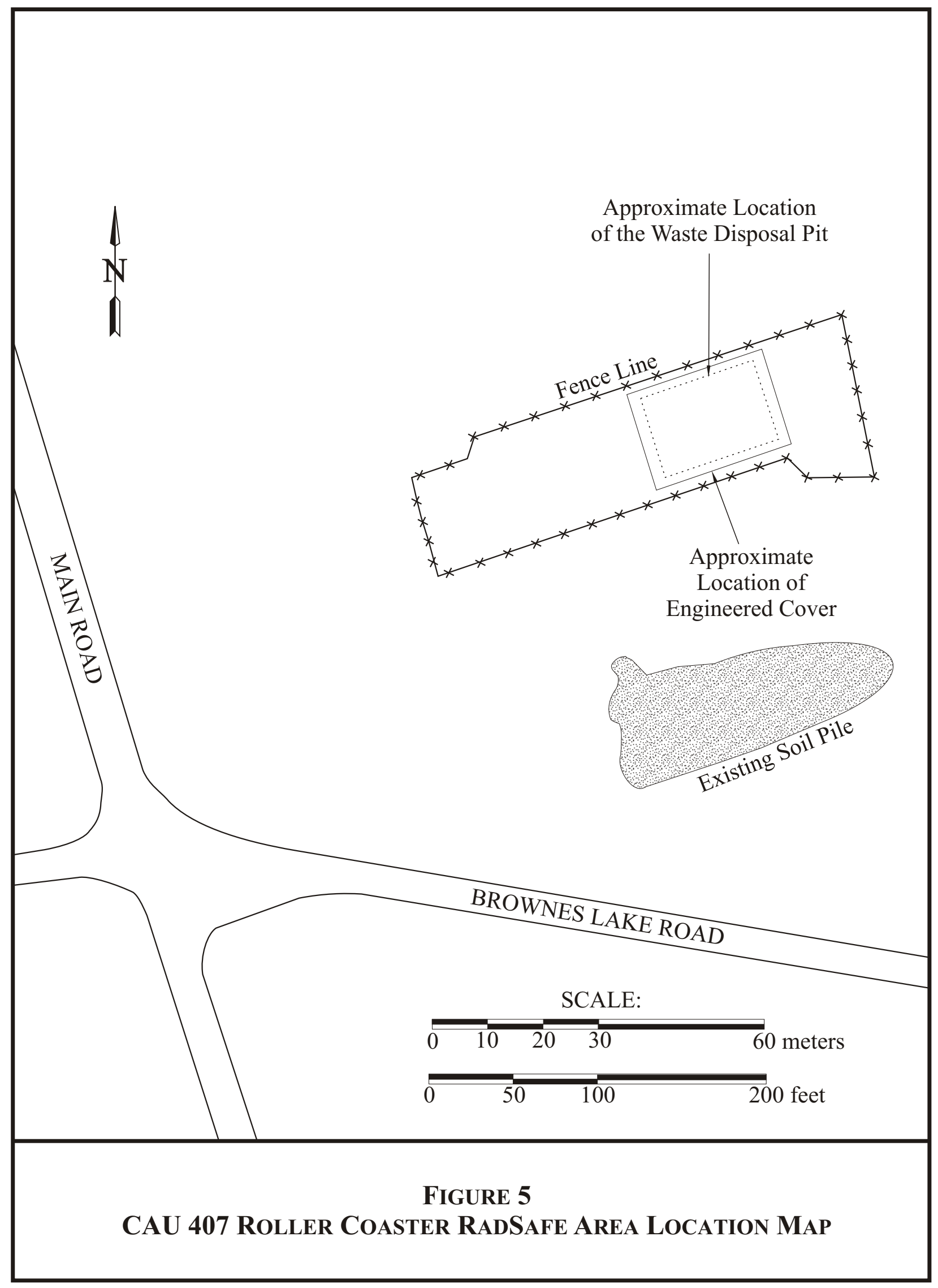




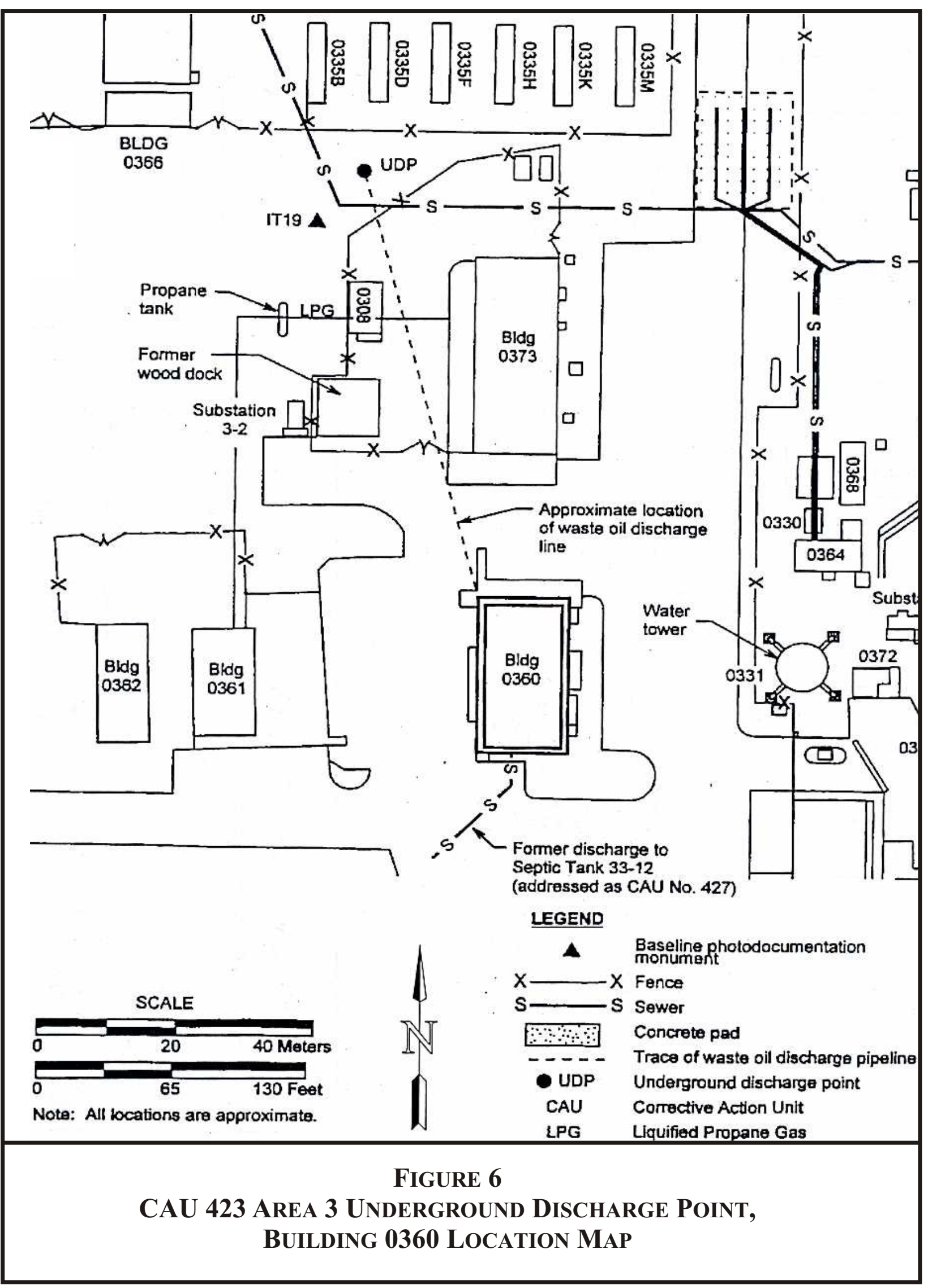




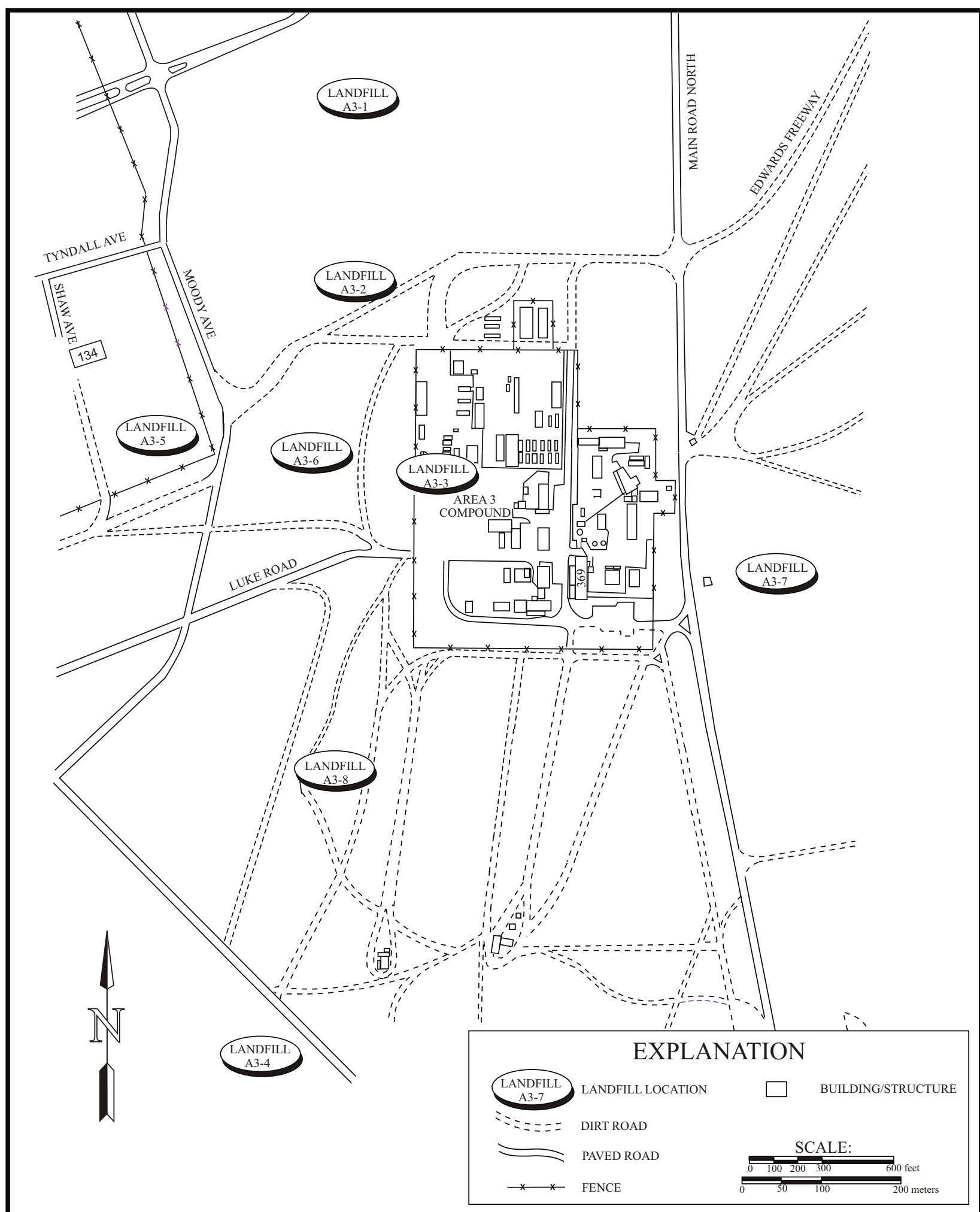

FIGURE 7

CAU 424 Area 3 LANDFILl CoMpleXes LoCATion MAP 
Post-Closure Inspection Report - TTR Revision: 0

Date: June 2006

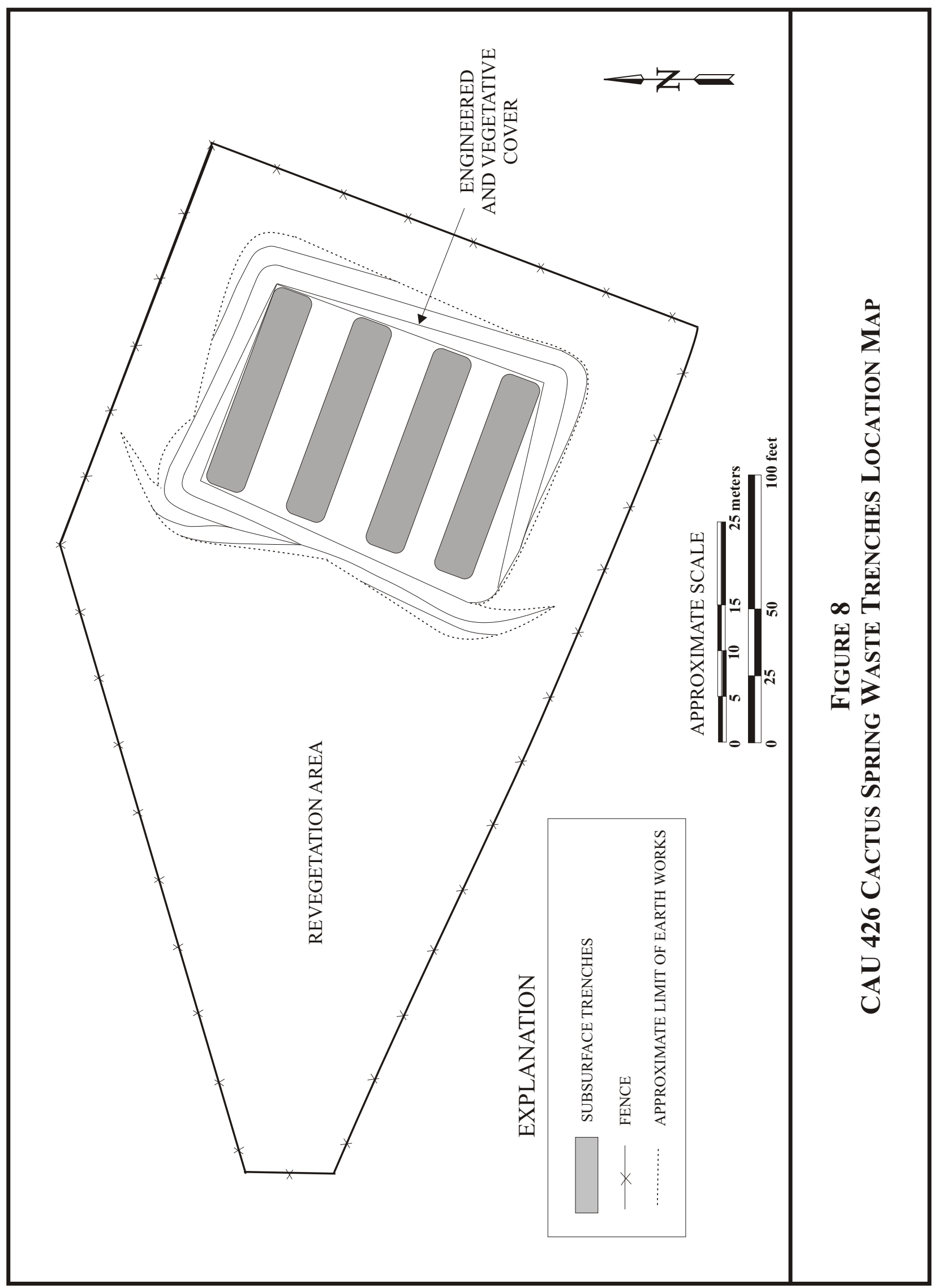




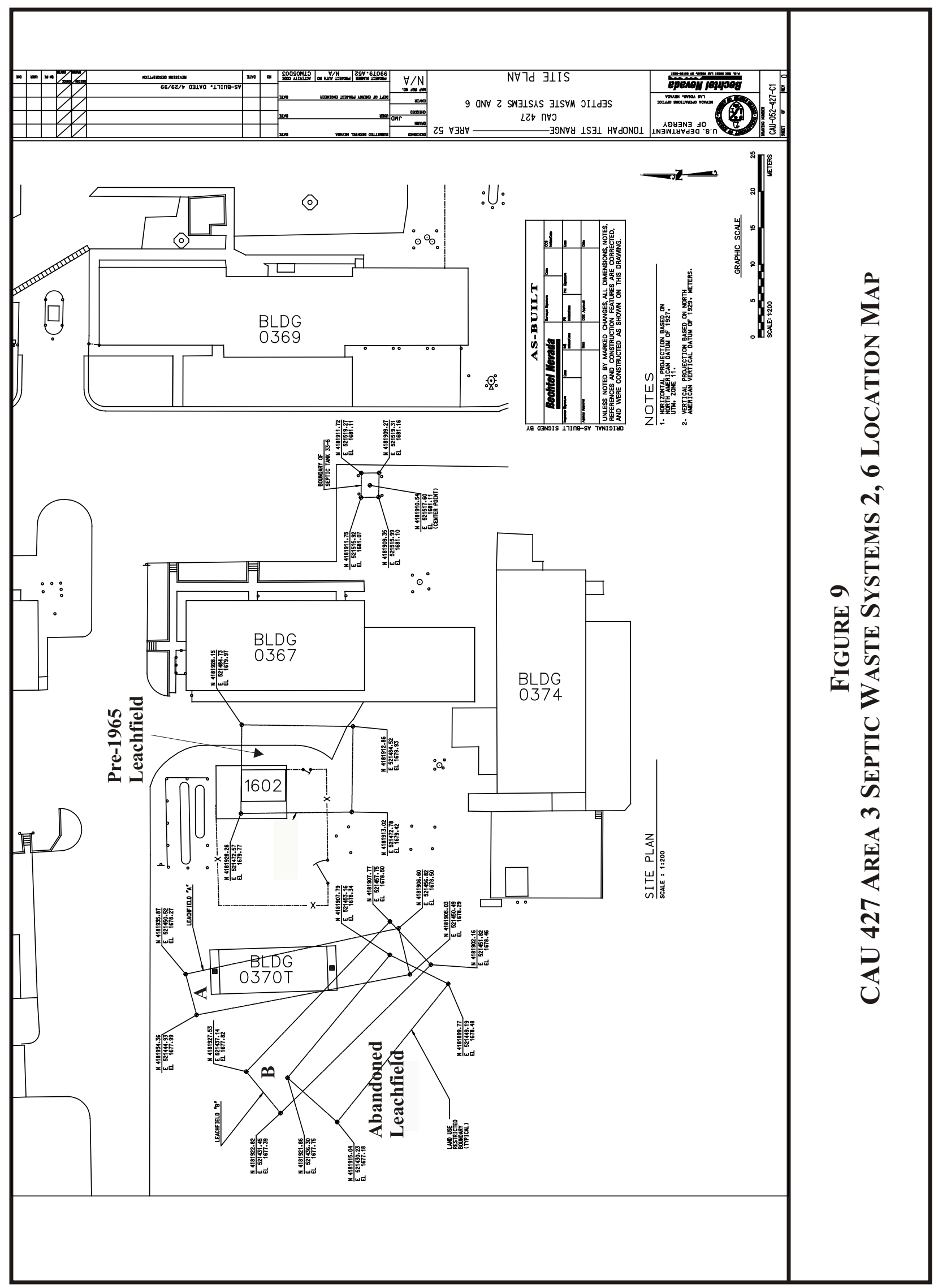


Post-Closure Inspection Report - TTR

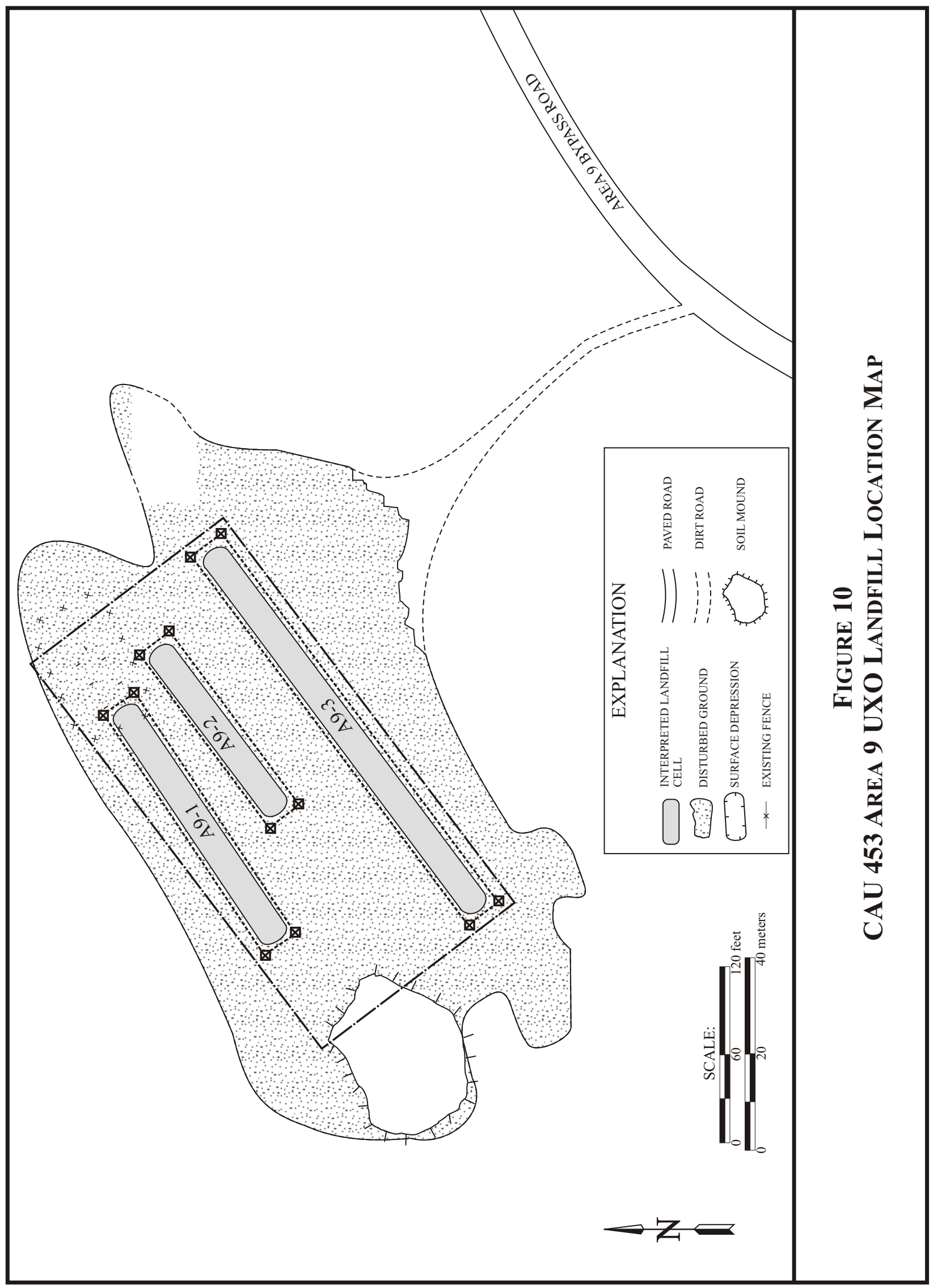




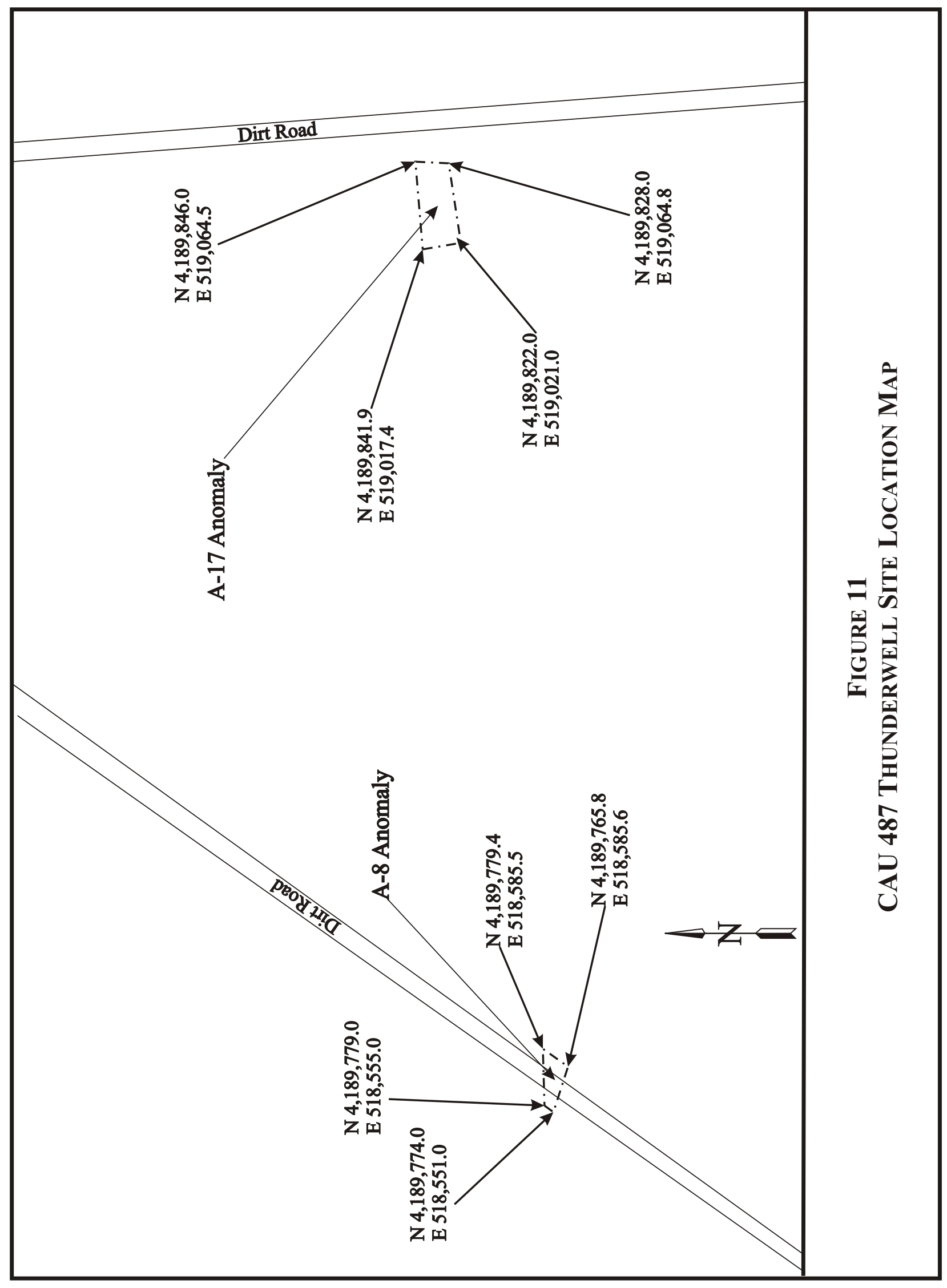


Post-Closure Inspection Report - TTR

Revision: 0

Date: June 2006

\section{ATTACHMENT B.}

\section{Post-Closure Inspection Plans}


Post-Closure Inspection Report - TTR

Revision: 0

Date: June 2006

THIS PAGE INTENTIONALLY LEFT BLANK 


\section{CORRECTIVE ACTION UNIT (CAU) 404: ROLLER COASTER LAGOONS AND TRENCH POST-CLOSURE INSPECTION PLAN}

The following text appeared in the published and approved CAU $404 \mathrm{CR}$, Closure Report for Corrective Action Unit 404: Roller Coaster Sewage Lagoons and North Disposal Trench, Tonopah Test Range, Nevada, Revision 0, September 1998, DOE/NV-11718-187 UC-702. Las Vegas, Nevada

Post-Closure monitoring of the covers is intended to determine:

- If maintenance repairs to the perimeter fence are required.

- If remedial action is necessary to establish a vegetative cover.

- If maintenance and repairs to the engineered cover is required.

- When a cessation to post-closure monitoring can be proposed.

\section{POST-CLOSURE MONITORING}

The monitoring will consist of biannual (twice per year) visual inspections of:

- The cover for condition (subsidence, significant erosion, unauthorized excavation, etc.) and plant development.

- $\quad$ The fence and signs to determine if repairs are required.

Additional, nonscheduled inspections may be required after severe weather events such as heavy rainfall, flash flooding, and high winds. Any identified maintenance and repair requirements will be remediated within 90 days of discovery and documented in writing at the time of repair. Additional revegetation work would be conducted during the next revegetation window (October to February).

Intrusion into or sampling of the impacted materials in the East or West Sewage Lagoon is not proposed during the post-closure monitoring period.

Monitoring of the vegetative cover will be conducted during the first, third, and fifth year after revegetation. Monitoring during the first year will determine if germination of seeded plant species has occurred. By the third year, plant establishment will be evaluated. By the fifth year, the objective of determining if burrowing animals have moved onto the site and to what depth they might be expected to penetrate the cover. The erosion condition of the soil will be evaluated using a qualitative erosion condition classification developed by the Bureau of Land Management. Information gathered will be compared to natural conditions and will be used in assessing whether or not remedial action is necessary so that a viable vegetative cover is established.

\section{ANNUAL REPORTING}

An annual report will be prepared that will provide the observations and describe modifications and/or repairs made to the cover and cover area. The annual report will be prepared following 
the second inspection of each year that post-closure monitoring is conducted. The annual reports will include the following information:

- Discussion of observations

- Inspection checklist and maintenance record

- Conclusions and recommendations

A copy of each annual report will be submitted to the NDEP.

\section{DURATION}

The biannual inspections will be performed for five years after the planting of the vegetative covers, and will be documented on inspection forms.

Completion of post-closure monitoring of CAU 404 may be proposed after two consecutive years of visual inspections have not indicated the need to revegetate or provide maintenance to the vegetative covers. Completion of post-closure monitoring may be proposed within five years after the original revegetation of the site and include the removal of the fence since the plants will have attained a maturity to not be significantly affected by the grazing of wild horses. 


\section{CAU 407: ROLLER COASTER RADSAFE POST-CLOSURE INSPECTION PLAN}

The following text appeared in the published and approved CAU 407 CR, Closure Report for Corrective Action Unit 407: Roller Coaster RADSAFE Area, Tonopah Test Range, Nevada, Revision 1, December 2001, DOE/NV--694-Rev 1. Las Vegas, Nevada

\section{INSPECTIONS}

Inspections consist of visually inspecting the cover for signs of erosion, animal burrows, cracks, water ponding, vegetation, and inspecting the fencing and postings. Inspections will be performed twice during the first six months after construction of the cover has been completed. After completion of the quarterly inspections, the cover systems will be inspected and monitored semiannually (twice per year) for the next two years. The frequency after the second year will be determined by NDEP, based on the results of the previous inspections. Any identified maintenance and repair requirements will be remedied within 90 working days of discovery and documented in writing at the time of repair.

Results of all inspections in a given year will be addressed in a single annual report. The annual report will include the following information:

- Discussion of observations.

- Inspection checklist and maintenance record.

- Conclusions and recommendations.

A copy of each annual report will be submitted to the NDEP. A copy of the inspection checklist is provided in Attachment $B$. 
Post-Closure Inspection Report - TTR

Revision: 0

Date: June 2006

\section{THIS PAGE INTENTIONALLY LEFT BLANK}




\section{CAU 423: AREA 3 BUILDING 0360 UNDERGROUND DISCHARGE POINT POST-CLOSURE INSPECTION PLAN}

The following text appeared in the approved and published Record of Technical Change Number CR-1 to the CAU 423 CR, Closure Report for Corrective Action Unit 423: Area 3 Building 03-60 Underground Discharge Point, Tonopah Test Range, Nevada, Revision 0, July 1999, DOE/NV/11718--319. Las Vegas, Nevada

Post-closure monitoring at CAU 423 will consist of biannual inspections (twice per year) to verify that the warning sign and concrete marker are in good condition and that the Use Restriction has been maintained. Any identified maintenance or repair requirements will be remedied within 90 working days of discovery and documented in writing at the time of repair. Results of all inspections in a given year will be addressed in a single annual report. The annual report will include the following information:

- Discussion of observations

- Inspection checklist and maintenance record

- Conclusions and recommendations

A copy of each annual report will be submitted to the NDEP. 
Post-Closure Inspection Report - TTR

Revision: 0

Date: June 2006

\section{THIS PAGE INTENTIONALLY LEFT BLANK}




\section{CAU 424: AREA 3 LANDFILL COMPLEXES POST-CLOSURE INSPECTION PLAN}

The following text appeared in the published and approved CAU $424 \mathrm{CR}$, $\underline{\text { Closure Report for }}$ Corrective Action Unit 424: Area 3 Landfill Complexes, Tonopah Test Range, Nevada, Revision 0, July 1999, DOE/NV/11718--283. Las Vegas, Nevada

Post-closure inspection of the Area 3 Landfill sites is intended to determine:

- If maintenance repairs to the landfill soil covers are needed.

- If maintenance and repairs to the landfill markers and warning signs are needed.

- If modifications to the Use Restriction administrative controls are needed.

- If termination of post-closure inspection can be proposed in the future.

\section{POST-CLOSURE INSPECTION}

The inspection will consist of biannual (twice per year) visual inspections of:

- The soil cover for indications of subsidence, erosion, unauthorized use, etc.

- The landfill markers and warning signs, to verify they are in-place, intact, and readable.

- The inspections will be documented on a checklist and with photography, if needed.

If damage to the soil covers, landfill markers, or warning signs is noted, then maintenance will be performed and may include placement and compaction of additional backfill, and repair or replacement of markers and signs. Additional nonscheduled inspections may be required after severe weather events such as heavy rainfall, flash flooding, and high winds. Any identified maintenance and repair requirements will be remedied within 90 days of discovery and documented in writing at the time of repair.

\section{ANNUAL REPORTING}

An annual report will be prepared that will provide the observations and describe modifications and/or repairs made to the cover and cover area. The annual post-closure inspection report will be prepared and submitted to NDEP following the second inspection of each year that post-closure inspection is conducted. The annual reports will include the following information:

- Discussion of observations.

- Inspection checklist and maintenance record.

- Conclusions and recommendations.

\section{DURATION}

The biannual inspections will be performed for five years after the completion of closure activities, and will be documented on inspection forms. 
Date: June 2006

Completion of post-closure inspection of CAU 424 may be proposed by DOE/NV to the NDEP after two consecutive years of visual inspections have not indicated recurrence of subsidence. Completion of post-closure monitoring may be proposed by DOE/NV to the NDEP within five years after the completion of closure activities. 


\section{CAU 426: CACTUS SPRING WASTE TRENCHES POST-CLOSURE INSPECTION PLAN}

The following text appeared in the published and approved CAU 426 CR, Closure Report for Corrective Action Unit 426: Cactus Spring Waste Trenches, Tonopah Test Range, Nevada, Revision 0, August 1998, DOE/NV/11718-226 UC-702. Las Vegas, Nevada

Post-Closure of the covers is intended to determine:

- If maintenance repairs to the perimeter fence are required.

- If remedial action is necessary to establish a vegetative cover.

- If maintenance and repairs to the engineered cover is required.

- When a cessation to post-closure monitoring can be proposed.

\section{POST-CLOSURE MONITORING}

The monitoring will consist of biannual (twice per year) visual inspections of:

- The cover for condition (subsidence, significant erosion, unauthorized excavation, etc.) and plant development.

- $\quad$ The fence and signs to determine if repairs are required.

Additional, nonscheduled inspections may be required after severe weather events such as heavy rainfall, flash flooding, and high winds. Any identified maintenance and repair requirements will be remediated within 90 days of discovery and documented in writing at the time of repair. Additional revegetation work would be conducted during the next revegetation window (October to February).

Intrusion into or sampling of the trench contents is not proposed during the post-closure monitoring period.

Monitoring of the vegetative cover will be conducted during the first, third, and fifth year after revegetation. Monitoring during the first year will determine if germination of seeded plant species has occurred. By the third year, plant establishment will be evaluated. By the fifth year, the objective of determining if burrowing animals have moved onto the site and to what depth they might be expected to penetrate the cover. The erosion condition of the soil will be evaluated using a qualitative erosion condition classification developed by the Bureau of Land Management. Information gathered will be compared to natural conditions and will be used in assessing whether or not remedial action is necessary so that a viable vegetative cover is established.

\section{ANNUAL REPORTING}

An annual report will be prepared that will provide the observations and describe modifications and/or repairs made to the cover and cover area. The annual report will be prepared following 
the second inspection of each year that post-closure monitoring is conducted. The annual reports will include the following information:

- Discussion of observations.

- Inspection checklist and maintenance record.

- Conclusions and recommendations.

A copy of each annual report will be submitted to the NDEP.

\section{DURATION}

The biannual inspections will be performed for five years after the planting of the vegetative covers, and will be documented on inspection forms.

Completion of post-closure monitoring of CAU 426 may be proposed after two consecutive years of visual inspections have not indicated the need to revegetate or provide maintenance to the vegetative covers. Completion of post-closure monitoring may be proposed within five years after the original revegetation of the site and include the removal of the fence since the plants will have attained a maturity to not be significantly affected by the grazing of wild horses. 


\section{CAU 427: AREA 3 SEPTIC WASTE SYSTEMS 2, 6 POST-CLOSURE INSPECTION PLAN}

The following text appeared in the published and approved CAU $427 \mathrm{CR}$, Closure Report for Corrective Action Unit 427 Area 3 Septic Waste Systems 2 and 6, Tonopah Test Range, Nevada, Revision 0, August 1999, DOE/NV--561. Las Vegas, Nevada

Post-Closure inspection of CAU 427 use restricted land is intended to determine:

- If maintenance and repairs to the closed leachfield or septic tank soil and asphalt covers are needed.

- If maintenance and repairs to the closed leachfield and septic tank markers and warning signs are needed.

- If modifications to the Use Restriction administrative controls are needed.

- If termination of post-closure inspection can be proposed in the future.

\section{POST-CLOSURE INSPECTION}

The inspection will consist of annual (once per year) visual inspections of:

- The soil and asphalt cover for indications of subsidence, erosion, unauthorized use, etc.

- The leachfield and septic tank markers and warning signs to verify they are in-place, intact, and readable

- The inspections will be documented on a checklist (Attachment C) and, if needed, with photography

Repairs to the soil covers (placement and compaction of additional backfill), landfill markers, and warning signs (repair, reposition, and/or replacement) may be required.

Inspections are not required after severe weather events such as heavy rainfall, flash floods, and high winds, because the leachfield waste is buried in the subsurface. However, any identified maintenance and repair requirements noted before or after a inspection will be remedied within 90 days of discovery and documented in writing at the time of repair.

\section{ANNUAL REPORTING}

An annual report will provide the inspector's observations of CAU 427s land-use-restricted areas and describe modifications and/or repairs made to Leachfield A, Leachfield B, Pre-1965 Leachfield, 1965-1975 Leachfield, and/or Septic Tank 33-5. The annual post-closure inspection report will be prepared and submitted to NDEP before the completion of the fiscal year in which the inspection was conducted. The annual reports will include the following information:

- Discussion of observations.

- Inspection checklist and maintenance record.

- Conclusions and recommendations. 


\section{DURATION}

The biannual inspections will be performed for five years after the completion of closure activities, and will be documented on inspection forms.

Completion of post-closure monitoring of CAU 427 may be proposed by the DOE/NV to the NDEP if after two consecutive years of visual inspections, indications of subsidence depression recurrences have not been detected. Completion of post-closure inspection may be proposed by $\mathrm{DOE} / \mathrm{NV}$ to the NDEP within five years after the completion of closure activities. 


\section{CAU 453: AREA 9 UXO LANDFILL INSPECTION PLAN}

The following text appeared in the published and approved CAU 453 CR, Closure Report for Corrective Action Unit 453: Area 9 UXO-Landfill, Tonopah Test Range, Nevada, Revision 0, July 1999, DOE/NV/11718--284. Las Vegas, Nevada

Post-Closure of the covers is intended to determine:

- If maintenance and repairs to the cell soil covers are needed.

- If maintenance and repairs to the perimeter fence, warning signs, and monuments are needed.

- If modifications to the administrative Use Restrictions are needed.

- If termination of post-closure inspection can be proposed in the future.

\section{POST-CLOSURE INSPECTION}

The inspection will consist of biannual (once per year) visual inspections of:

- The cell soil cover, for indications of subsidence, erosion, unauthorized use, etc.

- The perimeter fence, warning signs, and monuments, for signs of wear disturbance, etc.

The inspections will be documented on a checklist and with photography, if needed. Repairs to the cell soil covers (placement and compaction of additional fill), perimeter fence, warning signs, and monuments (repair, reposition, and/or replacement) may be required. Additional, nonscheduled inspections may be required after severe weather events such as heavy rainfall, flash flooding, and high winds. Any identified maintenance and repair requirements will be remediated within 90 days of discovery and documented in writing at the time of repair.

\section{ANNUAL REPORTING}

An annual post-closure inspection report will be prepared that will provide the observations and describe modifications and/or repairs made to the cover and cover area. The annual report will be prepared and submitted to NDEP following the second inspection of each year that post-closure inspection is conducted. The annual reports will include the following information:

- Discussion of observations.

- Inspection checklist and maintenance record.

- Conclusions and recommendations.

\section{DURATION}

The biannual inspections will be performed for five years after the completion of closure activities, and will be documented on inspection forms.

Completion of post-closure inspection of CAU 453 may be proposed by DOE/NV to NDEP within five years after the completion of closure activities. Completion of post-closure 
Post-Closure Inspection Report - TTR

Revision: 0

Date: June 2006

inspection may also be proposed by DOE/NV to NDEP if two consecutive years of visual inspections do not indicate the recurrence of subsidence depressions. 


\section{CAU 487: THUNDERWELL SITE, POST-CLOSURE INSPECTION PLAN}

The following text appeared in the published and approved Record of Technical Change Number 2 for the final Corrective Action Decision Document/Closure Report for Corrective Action Unit 487: Thunderwell Site, Tonopah Test Range, Nevada, Revision 0, November 2001, DOE/NV--761. Las Vegas, Nevada

The post-closure inspection of CAS RG-26-001-RGRV will consist of semi-annual (twice per year) visual inspections of the monument markers and postings to verify that they are in-place, intact, and readable. Visual inspections of the monuments and signage, and indications of ground disturbance within the Use Restriction area will be conducted. Observations and any modifications and/or repairs to the monuments or postings will be included in the annual Post-Closure Inspection Report for the Tonopah Test Range, Nevada. 
Post-Closure Inspection Report - TTR

Revision: 0

Date: June 2006

THIS PAGE INTENTIONALLY LEFT BLANK 
Post-Closure Inspection Report - TTR

Revision: 0

Date: June 2006

\section{Attachment C. Post-Closure InSPECTION CHECKLISTS}


Post-Closure Inspection Report - TTR

Revision: 0

Date: June 2006

THIS PAGE INTENTIONALLY LEFT BLANK 
CAU 400: 5 POINTS LANDFILL, POST-CLOSURE INSPECTION CHECKLIST

Inspection Date: 01 June 2005

Responsible Agency: NNSANSO ER

Date of Last Inspection: 10 November 2004

NNSA Project Manager: Kevin Cabble

Reason for Last Inspection: Semiannual inspection

Inspector (name, title, organization): Brad Jackson BNER

Assistant Inspector (name, title, organization): N/A

\section{A. GENERAL INSTRUCTIONS}

1. All checklist items must be completed and detailed comments made to document the results of the site inspection. The completed checklist is part of the field record of the inspection. Additional pages should be used as necessary to ensure that a complete record is provided. Attach the additional pages and number all pages upon completion of the inspection.

2. Any checklist line item marked by an inspector in a SHADED BOX, must be fully explained or an appropriate reference to previous reports provided. The purpose of this requirement is to provide a written explanation of inspector observations and the inspector's rationale for conclusions and recommendations. Explanations are to be placed on additional attachments and cross-referenced appropriately. Explanations, in addition to narrative, will take the form of sketches, measurements, and annotated site maps.

3. The site inspection is a walking inspection of the entire site including the perimeter and sufficient transects to be able to examine the entire surface and all features specifically described in the checklist.

4. A standard set of color $35 \mathrm{~mm}$ photographs (or equivalent) is required. In addition, all anomalous features or new features (such as changes in adjacent area land use) are to be photographed. A photo log entry will be made for each photograph taken.

5. This unit will be inspected biannually with formal reporting to the Nevada Division of Environmental Protection to be done annually. The annual report will include an executive summary, this inspection checklist with field notes and photo log attached, and recommendations and conclusions.

\begin{tabular}{|c|c|c|c|}
\hline B. PREPARATION (To be completed prior to site visit) & YES & No & EXPLANATION \\
\hline 1. Site as-built plans and site base map reviewed. & $\mathrm{X}$ & 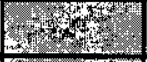 & \\
\hline 2. Previous inspection reports reviewed. & $\mathrm{X}$ & 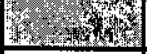 & \\
\hline a. Were anomalies or trends detected on previous inspections? & & $\underline{X}$ & \\
\hline b. Was maintenance performed? & & $\mathrm{X}$ & \\
\hline 3. Site maintenance and repair records reviewed. & $\mathrm{X}$ & $-3 x+4$ & \\
\hline a. Has site repair resulted in a change from as-built conditions? & & $\mathrm{X}$ & \\
\hline b. Are revised as-builts available that reflect repair changes? & & 觔能 & $\mathrm{N} / \mathrm{A}$ \\
\hline C. SITE INSPECTION (To be completed during inspection) & YES & NO & EXPLANATION \\
\hline \multicolumn{4}{|l|}{ 1. Adjacent off-site features within watershed areas. } \\
\hline a. Have there been any changes in use of adjacent area? & & $X$ & \\
\hline b. Are there any new roads or trails? & & $\mathrm{X}$ & \\
\hline c. Has there been a change in the position of nearby washes? & & $\mathrm{X}$ & \\
\hline $\begin{array}{l}\text { Has there been lateral excursion or erosion/deposition of nearby } \\
\text { washes? }\end{array}$ & & $\mathrm{x}$ & \\
\hline e. Are there new drainage channels? & (6inising & $\mathbf{x}$ & \\
\hline f. Change in surrounding vegetation? & S-8, & $\mathrm{X}$ & \\
\hline \multicolumn{4}{|l|}{ 2. Security fence, signs. } \\
\hline $\begin{array}{l}\text { a. Displacement of fences, site markers, boundary markers, or } \\
\text { monuments? }\end{array}$ & (3) & $\mathrm{x}$ & \\
\hline $\begin{array}{l}\text { b. Have any signs been damaged gr removed? } \\
\text { (Number of signs replaced: }\end{array}$ & & $\mathrm{x}$ & \\
\hline c. Were gates locked? & thex & $\mathrm{X}$ & Not required \\
\hline
\end{tabular}




\section{CAU 400: 5 POINTS LANDFILL, POST-CLOSURE INSPECTION CHECKLIST}

3. Waste Unit cover

a. Is there evidence of settling?

b. Is there cracking?

c. Is there evidence of erosion around the cap (wind or water)?

d. Is there evidence of animal burrowing?

e. Have the site markers been disturbed by man or natural processes?

f. Do natural processes threaten to integrity of any cover or site marker?

g. Other?

4. Vegetative cover

a. Is perimeter fence or mesh fencing damaged?

b. Is there evidence of horses or rabbits on site?

c. Is organic mulch and/or plants adequate to prevent erosion?

d. Are weedy annual plants present? If yes, are they a problem?

e. Are seeded plant species found on site?

f. Is there evidence of plant mortality?

5. Photo Documentation

a. Has a photo $\log$ been prepared?

b. Number of photos exposed (7)

YES NO EXPLANATION

\begin{tabular}{|c|c|l|}
\hline & $\mathrm{X}$ & \\
\hline & $\mathrm{X}$ & \\
\hline & $\mathrm{X}$ & \\
\hline $\mathrm{X}$ & & Some small animal burrows \\
\hline & $\mathrm{X}$ & \\
\hline & $\mathrm{X}$ & \\
\hline & & \\
\hline & $\mathrm{X}$ & \\
\hline
\end{tabular}

FIELD CONCLUSIONS

1. Is there an imminent hazard to the integrity of the unit? (Immediate report required)

$\mathrm{X}$

Person/Agency to whom report made: N/A

2. Are more frequent inspections required?

3. Are existing maintenance/repair actions satisfactory?

4. Is other maintenance/repair necessary?

5. Is current status/condition of vegetative cover satisfactory?

6. Rationale for field conclusions: Site is in generally good condition. Previously completed repairs look good.

\section{E. CERTIFICATION}

I have conducted an inspection of the 5 Points Landfill, CAU 400, at the TTR in accordance with the Post-Closure Monitoring Plan (see Closure Report) as recorded on this checklist, attached sheets, field notes, photo logs, and photographs.

Chief Inspector's Si\&nature:

Printed Name: Brad Jackson

Title: TTR PCI Task Manager

Date: 01 June 2005 


\section{CAU 400: BOMBLET PIT, POST-CLOSURE INSPECTION CHECKLIST}

Inspection Date: 01 June 2005

Responsible Agency: NNSANSO ER

Date of Last Inspection: 10 November 2004 NNSA Project Manager: Kevin Cabble

Inspector (name, title, organization): Brad Jackson BNER

Assistant Inspector (name, title, organization): N/A

\section{A. GENERAL INSTRUCTIONS}

1. All checklist items must be completed and detailed comments made to document the results of the site inspection. The completed checklist is part of the field record of the inspection. Additional pages should be used as necessary to ensure that a complete record is provided. Attach the additional pages and number all pages upon completion of the inspection.

2. Any checklist line item marked by an inspector in a SHADED BOX, must be fully explained or an appropriate reference to previous reports provided. The purpose of this requirement is to provide a written explanation of inspector observations and the inspector's rationale for conclusions and recommendations. Explanations are to be placed on additional attachments and cross-referenced appropriately. Explanations, in addition to narrative, will take the form of sketches, measurements, and annotated site maps.

3. The site inspection is a walking inspection of the entire site including the perimeter and sufficient transects to be able to examine the entire surface and all features specifically described in the checklist.

4. A standard set of color $35 \mathrm{~mm}$ photographs (or equivalent) is required. In addition, all anomalous features or new features (such as changes in adjacent area land use) are to be photographed. A photo log entry will be made for each photograph taken.

5. This unit will be inspected biannually with formal reporting to the Nevada Division of Environmental Protection to be done annually. The annual report will include an executive summary, this inspection checklist with field notes and photo log attached, and recommendations and conclusions.

B. PREPARATION (To be completed prior to site visit)

1. Site as-built plans and site base map reviewed.

2. Previous inspection reports reviewed.

a. Were anomalies or trends detected on previous inspections?

b. Was maintenance performed?

3. Site maintenance and repair records reviewed.

a. Has site repair resulted in a change from as-built conditions?

b. Are revised as-builts available that reflect repair changes?

C. SITE INSPECTION (To be completed during inspection)

1. Adjacent off-site features within watershed areas

a. Have there been any changes in use of adjacent area?

b. Are there any new roads or trails?

c. Has there been a change in the position of nearby washes?

d. Has there been lateral excursion or erosion/deposition of nearby washes?

e. Are there new drainage channels?

f. Change in surrounding vegetation?

2. Security fence, signs.

a. Displacement of fences, site markers, boundary markers, or monuments?

b. Have any signs been damaged gr removed? (Number of signs replaced:

c. Were gates locked?

\begin{tabular}{|c|c|c|}
\hline YES & NO & EXPLANATION \\
\hline $\mathrm{x}$ & 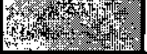 & \\
\hline $\mathrm{X}$ & r. & \\
\hline 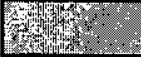 & $\mathrm{X}$ & \\
\hline 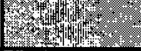 & $\mathrm{X}$ & \\
\hline $\mathrm{X}$ & $=7 x+2$ & \\
\hline $4 x+2 x$ & $\mathrm{X}$ & \\
\hline & $5-3 x$ & N/A \\
\hline YES & No & EXPLANATION \\
\hline 78 & $\mathbf{X}$ & \\
\hline & $\mathrm{X}$ & \\
\hline 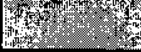 & $\mathrm{X}$ & \\
\hline 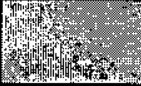 & $\mathrm{x}$ & \\
\hline & $\mathrm{X}$ & \\
\hline fectory & $\mathrm{X}$ & \\
\hline 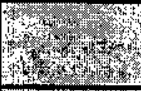 & $\mathrm{x}$ & All fencing is in good condition \\
\hline 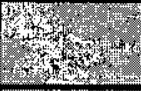 & $\mathbf{X}$ & \\
\hline 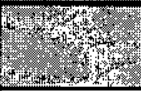 & $\mathrm{X}$ & Not required \\
\hline
\end{tabular}


CAU 400: BOMBLET PIT, POST-CLOSURE INSPECTION CHECKLIST

3. Waste Unit cover

a. Is there evidence of settling?

b. Is there cracking?

c. Is there evidence of erosion around the cap (wind or water)?

d. Is there evidence of animal burrowing?

e. Have the site markers been disturbed by man or natural processes?

f. Do natural processes threaten to integrity of any cover or site marker?

g. Other?

4. Vegetative cover

a. Is perimeter fence or mesh fencing damaged?

b. Is there evidence of horses or rabbits on site?

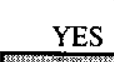

YES

NO EXPLANATION

c. Is organic mulch and/or plants adequate to prevent erosion?

d. Are weedy annual plants present? If yes, are they a problem?

e. Are seeded plant species found on site?

f. Is there evidence of plant mortality?

5. Photo Documentation

a. Has a photo log been prepared?

b. Number of photos exposed (7)

\section{FIELD CONCLUSIONS}

1. Is there an imminent hazard to the integrity of the unit? (Immediate report required)

\begin{tabular}{|c|c|c|}
\hline & & EAPLANAIIUN \\
\hline 15 & $\mathrm{X}$ & \\
\hline 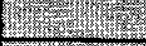 & $\mathrm{X}$ & \\
\hline tho & $\mathrm{X}$ & \\
\hline 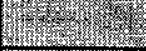 & $\mathrm{X}$ & \\
\hline & $\mathrm{X}$ & \\
\hline & $\mathrm{X}$ & \\
\hline mex & $\mathrm{x}$ & \\
\hline menting & $\mathrm{X}$ & \\
\hline $\mathrm{X}$ & Whing & $\begin{array}{l}\text { Horses outside of fence and some } \\
\text { rabbit/small animal burrows within site, } \\
\text { none significant. }\end{array}$ \\
\hline Mmes & $\mathrm{x}$ & \\
\hline $\mathrm{X}$ & Mrting & Some present, NNSA concurs not a problem \\
\hline $\mathrm{x}$ & Mmex & \\
\hline 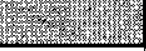 & $\mathrm{x}$ & \\
\hline$\underline{X}$ & 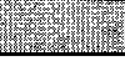 & \\
\hline YES & No & EXPLANATION \\
\hline r.rithy & $\mathrm{X}$ & \\
\hline
\end{tabular}

Person/Agency to whom report made:

2. Are more frequent inspections required?

3. Are existing maintenance/repair actions satisfactory?

4. Is other maintenance/repair necessary?

5. Is current status/condition of vegetative cover satisfactory?

\begin{tabular}{|c|c|c|}
\hline & $\mathrm{X}$ & \\
\hline $\mathrm{X}$ & 3. & \\
\hline X & $X$ & \\
\hline 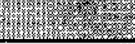 & $X$ & \\
\hline
\end{tabular}

6. Rationale for field conclusions: The site is in good condition and no maintenance/repairs are needed. Inspections are not required at this site but are completed as a best management practice under NNSA direction. As soon as vegetation is well established at the site, removal of the fence will be proposed to NNSA/NDEP per the closure report.

\section{E. CERTIFICATION}

I have conducted an inspection of the Bomblet Pit, CAU 400, at the TTR in accordance with the Post-Closure Monitoring Plan (see Closure Report) as recorded on this checklist, attached sheets, fiejetrotes, photo logs, and photographs.

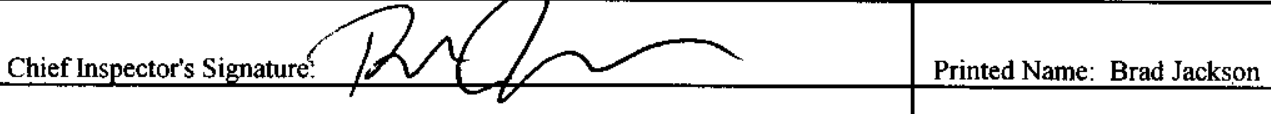

Title: TTR PCI Task Manger

Date: 01 June 2005 


\section{CAU 404: ROLLER COASTER LAGOONS \& N. DISPOSAL TRENCH, POST-CLOSURE MONITORING CHECKLIST}

Inspection Date: 01 June 2005

Responsible Agency: NNSA/NSO ER

Date of Last Inspection: 09 November 2004

NNSA Project Manager: Kevin Cabble

Reason for Last Inspection: Semiannual inspection

Inspector (name, title, organization): Brad Jackson BNER

Assistant Inspector (name, title, organization): N/A

\section{A. GENERAL INSTRUCTIONS}

1. All checklist items must be completed and detailed comments made to document the results of the site inspection. The completed checklist is part of the field record of the inspection. Additional pages should be used as necessary to ensure that a complete record is provided. Attach the additional pages and number all pages upon completion of the inspection.

2. Any checklist line item marked by an inspector in a SHADED BOX, must be fully explained or an appropriate reference to previous reports provided. The purpose of this requirement is to provide a written explanation of inspector observations and the inspector's rationale for conclusions and recommendations. Explanations are to be placed on additional attachments and cross-referenced appropriately. Explanations, in addition to narrative, will take the form of sketches, measurements, and annotated site maps.

3. The site inspection is a walking inspection of the entire site including the perimeter and sufficient transects to be able to examine the entire surface and all features specifically described in the checklist.

4. A standard set of color $35 \mathrm{~mm}$ photographs (or equivalent) is required. In addition, all anomalous features or new features (such as changes in adjacent area land use) are to be photographed. A photo log entry will be made for each photograph taken.

5. This unit will be inspected biannually with formal reporting to the Nevada Division of Environmental Protection to be done annually. The annual report will include an executive summary, this inspection checklist with field notes and photo log attached, and recommendations and conclusions.

\begin{tabular}{|c|c|c|c|}
\hline B. PREPARATION (To be completed prior to site visit) & YES & No & EXPLANATION \\
\hline 1. Site as-built plans and site base map reviewed. & $\mathrm{x}$ & 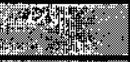 & \\
\hline 2. Previous inspection reports reviewed. & $\mathrm{X}$ & 2. & \\
\hline a. Were anomalies or trends detected on previous inspections? & & $\underline{x}$ & \\
\hline b. Was maintenance performed? & 4 & $\mathrm{X}$ & \\
\hline 3. Site maintenance and repair records reviewed. & $\mathbf{X}$ & 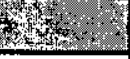 & \\
\hline a. Has site repair resulted in a change from as-built conditions? & 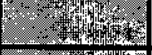 & $\mathrm{X}$ & \\
\hline b. Are revised as-builts available that reflect repair changes? & & $\mathrm{X}$ & N/A \\
\hline C. SITE INSPECTION (To be completed during inspection) & YES & NO & EXPLANATION \\
\hline \multicolumn{4}{|l|}{ 1. Adjacent off-site features within watershed areas. } \\
\hline a. Have there been any changes in use of adjacent area? & & $\mathbf{x}$ & \\
\hline b. Are there any new roads or trails? & & $\mathrm{x}$ & \\
\hline c. Has there been a change in the position of nearby washes? & & $\mathrm{x}$ & \\
\hline $\begin{array}{l}\text { d. Has there been lateral excursion or erosion/deposition of nearby } \\
\text { washes? }\end{array}$ & 4 & $\mathrm{x}$ & \\
\hline e. Are there new drainage channels? & 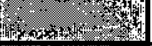 & $\mathrm{X}$ & \\
\hline f. Change in surrounding vegetation? & 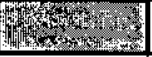 & $\underline{x}$ & \\
\hline \multicolumn{4}{|l|}{ 2. Security fence, signs. } \\
\hline $\begin{array}{l}\text { a. Displacement of fences, site markers, boundary markers, or } \\
\text { monuments? }\end{array}$ & $4 x^{2}+4$ & $\mathrm{x}$ & \\
\hline $\begin{array}{l}\text { b. Have any signs been damaged or removed? } \\
\text { (Number of signs replaced: }\end{array}$ & (3) & $\mathrm{x}$ & \\
\hline c. Were gates locked? & 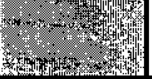 & $\mathrm{X}$ & Not required \\
\hline
\end{tabular}




\section{CAU 404: ROLLER COASTER LAGOONS \& N. DISPOSAL TRENCH, POST-CLOSURE MONITORING CHECKLIST}

3. Waste Unit cover.

a. Is there evidence of settling?

b. Is there cracking?

c. Is there evidence of erosion around the cap (wind or water)?

d. Is there evidence of animal burrowing?

e. Have the site markers been disturbed by man or natural processes?

f. Do natural processes threaten to integrity of any cover or site marker?

g. Other?

4. Vegetative cover.

a. Is perimeter fence or mesh fencing damaged?

b. Is there evidence of horses or rabbits on site?

c. Is organic mulch adequate to prevent erosion?

d. Are weedy annual plants present? If yes, are they a problem?

e. Are seeded plant species found on site?

f. Is there evidence of plant mortality?

5. Photo Documentation

a. Has a photo $\log$ been prepared?

b. Number of photos exposed (7)

\section{FIELD CONCLUSIONS}

1. Is there an imminent hazard to the integrity of the unit? (Immediate report required)

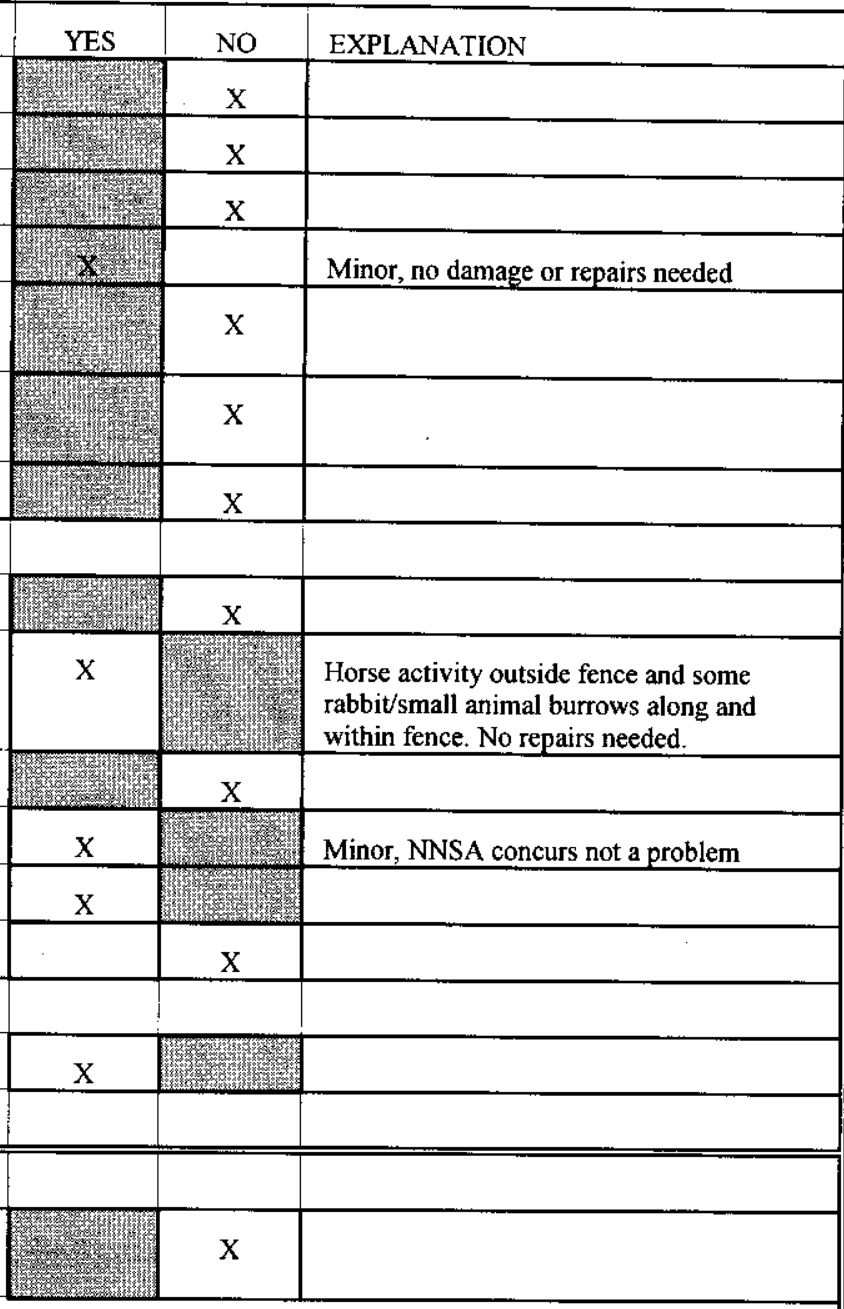

Person/Agency to whom report made:

2. Are more frequent inspections required?

3. Are existing maintenance/repair actions satisfactory?

4. Is other maintenance/repair necessary?

5. Is current status/condition of vegetative cover satisfactory?

\begin{tabular}{|c|c|}
\hline 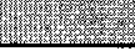 & $\mathrm{X}$ \\
\hline $\mathrm{X}$ & mexteres \\
\hline 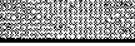 & $X$ \\
\hline $\mathrm{X}$ & mer \\
\hline
\end{tabular}

6. Rationale for field conclusions: The site is in good condition and there was no damage to the fencing or cover noted during the inspection. Some small animal burrows were noted during the inspection but no maintenance/repairs are needed.

\section{E. CERTIFICATION}

I have conducted an inspection of the Roller Coaster Sewage Lagoons \& North Disposal Trench, CAU 404, at the TTR in accordance with the PostClosure Monitoring Plan (see Closure Report) as recorded on this checklist, attached sheets, field notes, photo logs, and photographs.

Chief Inspector's Signature:
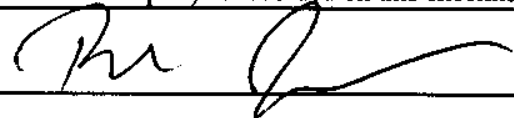

Printed Name: Brad Jackson

Title: TTR PCI Task Manager

Date: 01 June 2005 


\section{CAU 407: ROLLER COASTER RADSAFE AREA, POST-CLOSURE INSPECTION CHECKLIST}

Inspection Date: 01 June 2005

Responsible Agency: NNSA/NSO ER

NNSA Project Manager: Kevin Cabble

Date of Last Inspection: 09 November 2004

Reason for Last Inspection: Semiannual inspection

Inspector (name, title, organization): Brad Jackson BNER

Assistant Inspector (name, title, organization): N/A

\section{A. GENERAL INSTRUCTIONS}

1. All checklist items must be completed and detailed comments made to document the results of the site inspection. The completed checklist is part of the field record of the inspection. Additional pages should be used as necessary to ensure that a complete record is provided. Attach the additional pages and number all pages upon completion of the inspection.

2. Any checklist line item marked by an inspector in a SHADED BOX, must be fully explained or an appropriate reference to previous reports provided. The purpose of this requirement is to provide a written explanation of inspector observations and the inspector's rationale for conclusions and recommendations. Explanations are to be placed on additional attachments and cross-referenced appropriately.

Explanations, in addition to narrative, will take the form of sketches, measurements, and annotated site maps.

3. The site inspection is a walking inspection of the entire site including the perimeter and sufficient transects to be able to examine the entire surface and all features specifically described in the checklist.

4. A standard set of color $35 \mathrm{~mm}$ photographs (or equivalent) is required. In addition, all anomalous features or new features (such as changes in adjacent area land use) are to be photographed. A photo log entry will be made for each photograph taken.

5. This unit will be inspected biannually with formal reporting to the Nevada Division of Environmental Protection to be done annually. The annual report will include an executive summary, this inspection checklist with field notes and photo log attached, and recommendations and conclusions.

\begin{tabular}{|c|c|c|c|}
\hline B. PREPARATION (To be completed prior to site visit) & YES & No & EXPLANATION \\
\hline 1. Site as-built plans and site base map reviewed. & $\mathbf{X}$ & Hers & \\
\hline 2. Previous inspection reports reviewed. & $\mathbf{X}$ & 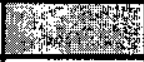 & \\
\hline a. Were anomalies or trends detected on previous inspections? & & $\mathrm{X}$ & \\
\hline b. Was maintenance performed? & 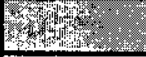 & $\mathrm{x}$ & \\
\hline 3. Site maintenance and repair records reviewed. & $\mathrm{x}$ & 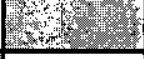 & \\
\hline a. Has site repair resulted in a change from as-built conditions? & & $\underline{X}$ & \\
\hline b. Are revised as-builts available that reflect repair changes? & & $\mathrm{X}$ & $\mathrm{N} / \mathrm{A}$ \\
\hline C. SITE INSPECTION (To be completed during inspection) & YES & No & EXPLANATION \\
\hline \multicolumn{4}{|l|}{ 1. Adjacent off-site features within watershed areas. } \\
\hline a. Have there been any changes in use of adjacent area? & & $\mathrm{x}$ & \\
\hline b. Are there any new roads or trails? & & $\mathrm{x}$ & \\
\hline c. Has there been a change in the position of nearby washes? & & $\mathbf{x}$ & \\
\hline $\begin{array}{l}\text { d. Has there been lateral excursion or erosion/deposition of nearby } \\
\text { washes? }\end{array}$ & & $\mathrm{X}$ & \\
\hline e. Are there new drainage channels? & 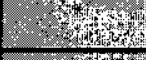 & $\mathrm{X}$ & \\
\hline f. Change in surrounding vegetation? & 10 & $\mathrm{X}$ & \\
\hline \multicolumn{4}{|l|}{ 2. Security fence, signs. } \\
\hline $\begin{array}{l}\text { a. Displacement of fences, site markers, boundary markers, or } \\
\text { monuments? }\end{array}$ & Hets & $\mathrm{x}$ & \\
\hline $\begin{array}{l}\text { b. Have any signs been damaged orfemoved? } \\
\text { (Number of signs replaced: }\end{array}$ & W & $\mathrm{x}$ & \\
\hline c. Were gates locked? & $y^{2}$ & $\mathrm{x}$ & Not required \\
\hline
\end{tabular}




\begin{tabular}{|c|c|c|c|}
\hline \multicolumn{4}{|c|}{ CAU 407: ROLLER COASTER RADSAFE AREA, POST-CLOSURE INSPECTION CHECKLIST } \\
\hline 3. Waste Unit cover. & \multirow{2}{*}{ YES } & \multirow{2}{*}{$\frac{\text { No }}{\mathrm{X}}$} & \multirow[t]{2}{*}{ EXPLANATION } \\
\hline a. Is there evidence of settling? & & & \\
\hline b. Is there cracking? & 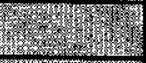 & $\mathrm{X}$ & \\
\hline c. Is there evidence of erosion around the cap (wind or water)? & 2. & $\mathrm{X}$ & \\
\hline d. Is there evidence of animal burrowing? & (3) & $\mathrm{X}$ & \\
\hline $\begin{array}{l}\text { e. Do natural processes threaten to integrity of any cover or site } \\
\text { marker? }\end{array}$ & 16. & $\mathrm{X}$ & \\
\hline f. Other? & minting & $\mathrm{X}$ & \\
\hline \multicolumn{4}{|l|}{ 4. Vegetative cover. } \\
\hline a. Is perimeter fence or mesh fencing damaged? & 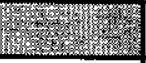 & $\mathrm{X}$ & \\
\hline b. Is there evidence of horses or rabbits on site? & $\mathrm{x}$ & & $\begin{array}{l}\text { Horses outside of fence and rabbits/small } \\
\text { animal burrows within fence }\end{array}$ \\
\hline c. Is organic mulch adequate to prevent erosion? & 2 & $\mathrm{X}$ & \\
\hline d. Are weedy annual plants present? If yes, are they a problem? & $\underline{x}$ & & Some present, NNSA concurs not a problem \\
\hline e. Are seeded plant species found on site? & $\mathrm{X}$ & & Newly planted \\
\hline f. Is there evidence of plant mortality? & 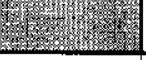 & $\mathrm{X}$ & \\
\hline \multicolumn{4}{|l|}{ 5. Photo Documentation } \\
\hline a. Has a photo $\log$ been prepared? & $x$ & 18 & \\
\hline b. Number of photos exposed (8) & & & \\
\hline \multicolumn{4}{|l|}{ D. FIELD CONCLUSIONS } \\
\hline $\begin{array}{l}\text { 1. Is there an imminent hazard to the integrity of the unit? (Immediate report } \\
\text { required) }\end{array}$ & 2. & $\mathrm{X}$ & \\
\hline \multicolumn{4}{|l|}{ Person/Agency to whom report made: } \\
\hline 2. Are more frequent inspections required? & Mrixym & $\mathrm{X}$ & \\
\hline 3. Are existing maintenance/repair actions satisfactory? & $\mathrm{X}$ & $\sqrt{y^{2}}$ & \\
\hline 4. Is other maintenance/repair necessary? & 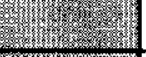 & $\mathrm{x}$ & \\
\hline 5. Is current status/condition of vegetative cover satisfactory? & $2.7 x_{10}$ & $\underline{X}$ & \\
\hline \multicolumn{4}{|c|}{$\begin{array}{l}\text { 6. Rationale for field conclusions: The site is in generally good condition. Maintenance to reestablish vegetation on the cover and repair some minor } \\
\text { erosion has been completed and new vegetation is present throughout the cover. }\end{array}$} \\
\hline \multicolumn{4}{|l|}{ E. CERTIFICATION } \\
\hline \multicolumn{4}{|c|}{$\begin{array}{l}\text { I have conducted an inspection of the Roller Coaster RadSafe Area, CAU 407, at the TTR in accordance with the Post-Closure Monitoring Plan (see } \\
\text { Closure Report) as recorded on this checklist, attached sheets, field notes, photo logs, and photographs. }\end{array}$} \\
\hline Chief Inspector's Signature: & \multicolumn{3}{|c|}{ Printed Name: Brad Jackson } \\
\hline Title: TTR PCI Task Manger & Date: $01 \mathrm{Ju}$ & 2005 & \\
\hline
\end{tabular}




\section{CAU 423: AREA 3 UNDERGROUND DISCHARGE POINT, POST-CLOSURE INSPECTION CHECKLIST}

Inspection Date: 02 June 2005

Responsible Agency: NNSA/NSO ER

Date of Last Inspection: 09 November 2004 NNSA Project Manager: Kevin Cabble

Inspector (name, title, organization): Brad Jackson BNER

Assistant Inspector (name, title, organization): N/A

\section{A. GENERAL INSTRUCTIONS}

1. All checklist items must be completed and detailed comments made to document the results of the site inspection. The completed checklist is part of the field record of the inspection. Additional pages should be used as necessary to ensure that a complete record is provided. Attach the additional pages and number all pages upon completion of the inspection.

2. Any checklist line item marked by an inspector in a SHADED BOX, must be fully explained or an appropriate reference to previous reports provided. The purpose of this requirement is to provide a written explanation of inspector observations and the inspector's rationale for conclusions and recommendations. Explanations are to be placed on additional attachments and cross-referenced appropriately.

Explanations, in addition to narrative, will take the form of sketches, measurements, and annotated site maps.

3. The site inspection is a walking inspection of the entire site including the perimeter and sufficient transects to be able to examine the entire surface and all features specifically described in the checklist.

4. A standard set of color $35 \mathrm{~mm}$ photographs (or equivalent) is required. In addition, all anomalous features or new features (such as changes in adjacent area land use) are to be photographed. A photo log entry will be made for each photograph taken.

5. This unit will be inspected biannually with formal reporting to the Nevada Division of Environmental Protection to be done annually. The annual report will include an executive summary, this inspection checklist with field notes and photo log attached, and recommendations and conclusions.

\begin{tabular}{|c|c|c|c|}
\hline B. PREPARATION (To be completed prior to site visit) & YES & NO & EXPLANATION \\
\hline 1. Site as-built plans and site base map reviewed. & $\mathbf{x}$ & 4 & \\
\hline 2. Previous inspection reports reviewed. & $\mathrm{x}$ & A. & \\
\hline a. Were anomalies or trends detected on previous inspections? & Woth & $\mathrm{X}$ & \\
\hline b. Was maintenance performed? & 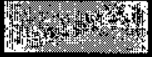 & $X$ & \\
\hline 3. Site maintenance and repair records reviewed. & 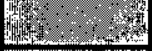 & $\mathrm{X}$ & N/A \\
\hline a. Has site repair resulted in a change from as-built conditions? & 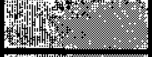 & $\mathbf{X}$ & N/A \\
\hline b. Are revised as-builts available that reflect repair changes? & $7+4$ & $\mathrm{X}$ & N/A \\
\hline C. SITE INSPECTION (To be cormpleted during inspection) & YES & NO & EXPLANATION \\
\hline 1. Adjacent off-site features within watershed areas. & & & \\
\hline a. Have there been any changes in use of adjacent area? & $\mathrm{X}$ & & $\begin{array}{l}\text { Water line installation is in process in the } \\
\text { area, the site is not disturbed }\end{array}$ \\
\hline b. Are there any new roads or trails? & $x^{2}$ & $\mathrm{X}$ & \\
\hline c. Has there been a change in the position of nearby washes? & X & 4 & $\begin{array}{l}\text { Water line installation is in process in the } \\
\text { area, the site is not disturbed }\end{array}$ \\
\hline $\begin{array}{l}\text { d. Has there been lateral excursion or erosion/deposition of nearby } \\
\text { washes? }\end{array}$ & 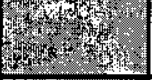 & $\mathrm{x}$ & \\
\hline e. Are there new drainage channels? & x-y & $\underline{x}$ & \\
\hline f. Change in surrounding vegetation? & 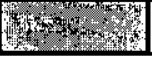 & $X$ & \\
\hline 2. Security fence, signs. & & & \\
\hline a. Displacement of site markers, boundary markers, or monuments? & $4 x+4$ & $\mathrm{X}$ & \\
\hline $\begin{array}{l}\text { b. Have any signs been damaged orgemoved? } \\
\text { (Number of signs replaced: }\end{array}$ & 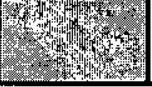 & $\mathbf{X}$ & \\
\hline
\end{tabular}




\section{CAU 423: AREA 3 UNDERGROUND DISCHARGE POINT, POST-CLOSURE INSPECTION CHECKLIST}

\begin{tabular}{|l|l|} 
3. Use Restricted Area: & YES
\end{tabular}

a. Is there evidence of settling?

b. Is there cracking?

c. Is there evidence of erosion (wind or water)?

d. Is there evidence of animal burrowing?

e. Have the site markers been disturbed by man or natural processes?

f. Is there vegetation in the area?

g. Do natural processes threaten to integrity of any cover or site marker?

h. Other?

\begin{tabular}{|r|c|l|}
\hline YES & $\mathrm{NO}$ & EXPLANATION \\
\hline & $\mathrm{X}$ & \\
\hline & $\mathrm{X}$ & \\
\hline & $\mathrm{X}$ & \\
\hline & $\mathrm{X}$ & \\
\hline & $\mathrm{X}$ & \\
\hline & $\mathrm{X}$ & \\
\hline & $\mathrm{X}$ & \\
\hline & $\mathrm{X}$ & \\
\hline
\end{tabular}

4. Photo Documentation

a. Has a photo $\log$ been prepared?

$\mathrm{X}$

b. Number of photos exposed (2)

\section{FIELD CONCLUSIONS}

1. Is there an imminent hazard to the integrity of the unit? (Immediate report required)

\begin{tabular}{|l|l|l|}
\hline & & \\
\hline & $\mathrm{X}$ & \\
\hline
\end{tabular}

Person/Agency to whom report made:

2. Are more frequent inspections required?

3. Are existing maintenance/repair actions satisfactory?

4. Is other maintenance/repair necessary?

5. Is current status/condition of the site satisfactory?

\begin{tabular}{|c|c|}
\hline & $\mathrm{X}$ \\
\hline $\mathrm{x}$ & $\mathrm{x}$ \\
\hline & $\mathrm{x}$ \\
\hline $\mathrm{x}$ & $\mathrm{x}$ \\
\hline
\end{tabular}

6. Rationale for field conclusions: Site is in good condition. NNSA requested a proposal to remove the piping running to the UDP.

\section{E. CERTIFICATION}

I have conducted an inspection of the Area 3 Underground Discharge Point, CAU 423, at the TTR in accordance with the Post-Closure Inspection Plan (see Closure Report) as recorded on this checklist, attached sheets, field notes, photo logs, and photographs.

Chief Inspector's Signature:

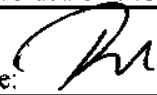

Title: TTR PCI Task Manager

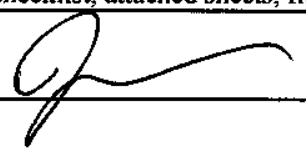

Printed Name: Brad Jackson

Date: 02 June 2005 


\section{CAU 424: AREA 3 LANDFILL COMPLEX, POST-CLOSURE INSPECTION CHECKLIST}

Inspection Date: 01 June 2005

Responsible Agency: NNSA/NSO ER

NNSA Project Manager: Kevin Cabble

Date of Last Inspection:09 November 2004

Reason for Last Inspection: Semiannual inspection

Inspector (name, title, organization): Brad Jackson BNER

Assistant Inspector (name, title, organization): N/A

\section{A. GENERAL INSTRUCTIONS}

1. All checklist items must be completed and detailed comments made to document the results of the site inspection. The completed checklist is part of the field record of the inspection. Additional pages should be used as necessary to ensure that a complete record is provided. Attach the additional pages and number all pages upon completion of the inspection.

2. Any checklist line item marked by an inspector in a SHADED BOX, must be fully explained or an appropriate reference to previous reports provided. The purpose of this requirement is to provide a written explanation of inspector observations and the inspector's rationale for conclusions and recommendations. Explanations are to be placed on additional attachments and cross-referenced appropriately.

Explanations, in addition to narrative, will take the form of sketches, measurements, and annotated site maps.

3. The site inspection is a walking inspection of the entire site including the perimeter and sufficient transects to be able to examine the entire surface and all features specifically described in the checklist.

4. A standard set of color $35 \mathrm{~mm}$ photographs (or equivalent) is required. In addition, all anomalous features or new features (such as changes in adjacent area land use) are to be photographed. A photo log entry will be made for each photograph taken.

5. This unit will be inspected biannually with formal reporting to the Nevada Division of Environmental Protection to be done annually. The annual report will include an executive summary, this inspection checklist with field notes and photo log attached, and recommendations and conclusions.

\begin{tabular}{|c|c|c|c|}
\hline B. PREPARATION (To be completed prior to site visit) & YES & No & EXPLANATION \\
\hline 1. Site as-built plans and site base map reviewed. & $\mathrm{x}$ & 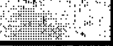 & \\
\hline 2. Previous inspection reports reviewed. & $\mathrm{x}$ & sxix & \\
\hline a. Were anomalies or trends detected on previous inspections? & & $\mathrm{X}$ & \\
\hline b. Was maintenance performed? & & $\mathrm{X}$ & \\
\hline 3. Site maintenance and repair records reviewed. & $\mathrm{X}$ & 巽 & \\
\hline a. Has site repair resulted in a change from as-built conditions? & & $\mathrm{X}$ & \\
\hline b. Are revised as-builts available that reflect repair changes? & & $\mathrm{X}$ & N/A \\
\hline C. SITE INSPECTION (To be completed during inspection) & YES & NO & EXPLANATION \\
\hline Adjacent off-site features within watershed areas. & & & \\
\hline a. Have there been any changes in use of adjacent area? & & $\mathrm{X}$ & \\
\hline b. Are there any new roads or trails? & & $\mathrm{X}$ & \\
\hline c. Has there been a change in the position of nearby washes? & & $\mathrm{X}$ & \\
\hline $\begin{array}{l}\text { d. Has there been lateral excursion or erosion/deposition of nearby } \\
\text { washes? }\end{array}$ & & $\mathrm{X}$ & \\
\hline e. Are there new drainage channels? & & $\mathrm{x}$ & \\
\hline f. Change in surrounding vegetation? & & $\mathrm{x}$ & \\
\hline 2. Security fence, signs. & & & \\
\hline $\begin{array}{l}\text { a. Displacement of fences, site markers, boundary markers, or } \\
\text { monuments? }\end{array}$ & 20. & $\mathrm{X}$ & \\
\hline $\begin{array}{l}\text { b. Have any signs been damaged or removed? } \\
\text { (Number of signs replaced: }\end{array}$ & 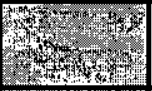 & $\mathrm{x}$ & \\
\hline c. Were gates locked? & (x) & $\mathrm{X}$ & N/A \\
\hline
\end{tabular}




\section{CAU 424: AREA 3 LANDFILL COMPLEX, POST-CLOSURE INSPECTION CHECKLIST}

\begin{tabular}{|c|c|c|c|}
\hline 3. Waste Unit cover. & YES & $\mathrm{NO}$ & EXPLANATION \\
\hline a. Is there evidence of settling? & & $\mathbf{X}$ & \\
\hline b. Is there cracking? & 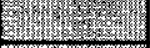 & $\mathrm{X}$ & \\
\hline c. Is there evidence of erosion around the cap (wind or water)? & 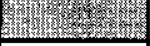 & $\mathrm{X}$ & \\
\hline d. Is there evidence of animal burrowing? & $\mathrm{X}$ & & Minor burrowing by small animals \\
\hline $\begin{array}{l}\text { e. Have the site markers been disturbed by man or natural } \\
\text { processes? }\end{array}$ & & $\mathrm{X}$ & \\
\hline f. Is the vegetation on the cover? & $\mathbf{X}$ & & \\
\hline $\begin{array}{l}\text { g. Do natural processes threaten to integrity of any cover or site } \\
\text { marker? }\end{array}$ & 3ring & $\mathrm{X}$ & \\
\hline h. Other? & 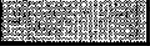 & $\mathrm{X}$ & \\
\hline \multicolumn{4}{|l|}{ 4. Photo Documentation } \\
\hline a. Has a photo $\log$ been prepared? & $\mathrm{X}$ & & \\
\hline b. Number of photos exposed (21) & & & \\
\hline \multicolumn{4}{|l|}{ D. FIELD CONCLUSIONS } \\
\hline $\begin{array}{l}\text { 1. Is there an imminent hazard to the integrity of the unit? (Immediate report } \\
\text { required) }\end{array}$ & 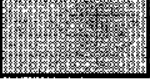 & $\mathrm{X}$ & \\
\hline \multicolumn{4}{|l|}{ Person/Agency to whom report made: } \\
\hline 2. Are more frequent inspections required? & & $\mathrm{X}$ & \\
\hline 3. Are existing maintenance/repair actions satisfactory? & $\mathrm{X}$ & 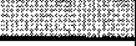 & \\
\hline 4. Is other maintenance/repair necessary? & (2. & $\mathrm{X}$ & \\
\hline 5. Is current status/condition of vegetative cover satisfactory? & $\mathrm{X}$ & & \\
\hline
\end{tabular}

6. Rationale for field conclusions: The site is in good condition and there was no damage to the fencing or cover noted during the inspection. Some small animal burrows were noted during the inspection. Previously completed repairs are in good condition.

\section{E. CERTIFICATION}

I have conducted an inspection of the Area 3 Landfill Complex, CAU 424, at the TTR in accordance with the Post-Closure Inspection Plan (see Closure Report) as recorded on this checklist, attached sheets, field notes, photo logs, and photographs.

\begin{tabular}{|l|l|l|}
\hline Chief Inspector's Signature: & Date: 01 June 2005 \\
\hline Title: TTR PCI Task Manager & Printed Name: Brad Jackson \\
\hline
\end{tabular}


CAU 426: CACTUS SPRING WASTE TRENCHES, POST-CLOSURE INSPECTION CHECKLIST

Inspection Date: 02 June 2005

Responsible Agency: NNSANSO ER

Date of Last Inspection: 09 November 2004

NNSA Project Manager: Kevin Cabble

Reason for Last Inspection: Semiannual inspection

Inspector (name, title, organization): Brad Jackson BNER

Assistant Inspector (name, title, organization): N/A

\section{A. GENERAL INSTRUCTIONS}

1. All checklist items must be completed and detailed comments made to document the results of the site inspection. The completed checklist is part of the field record of the inspection. Additional pages should be used as necessary to ensure that a complete record is provided. Attach the additional pages and number all pages upon completion of the inspection.

2. Any checklist line item marked by an inspector in a SHADED BOX, must be fully explained or an appropriate reference to previous reports provided. The purpose of this requirement is to provide a written explanation of inspector observations and the inspector's rationale for conclusions and recommendations. Explanations are to be placed on additional attachments and cross-referenced appropriately.

Explanations, in addition to narrative, will take the form of sketches, measurements, and annotated site maps.

3. The site inspection is a walking inspection of the entire site including the perimeter and sufficient transects to be able to examine the entire surface and all features specifically described in the checklist.

4. A standard set of color $35 \mathrm{~mm}$ photographs (or equivalent) is required. In addition, all anomalous features or new features (such as changes in adjacent area land use) are to be photographed. A photo log entry will be made for each photograph taken.

5. This unit will be inspected biannually with formal reporting to the Nevada Division of Environmental Protection to be done annually. The annual report will include an executive summary, this inspection checklist with field notes and photo log attached, and recommendations and conclusions.

\begin{tabular}{|c|c|c|c|}
\hline B. PREPARATION (To be completed prior to site visit) & YES & NO & EXPLANATION \\
\hline 1. Site as-built plans and site base map reviewed. & $\underline{x}$ & $y_{2}$ & \\
\hline 2. Previous inspection reports reviewed. & $\mathrm{x}$ & 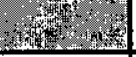 & \\
\hline a. Were anomalies or trends detected on previous inspections? & Se & $\underline{x}$ & \\
\hline b. Was maintenance performed? & & $\mathrm{X}$ & \\
\hline 3. Site maintenance and repair records reviewed. & $\mathrm{x}$ & (x) & \\
\hline a. Has site repair resulted in a change from as-built conditions? & & $\mathrm{X}$ & \\
\hline b. Are revised as-builts available that reflect repair changes? & & $\mathrm{X}$ & $\mathrm{N} / \mathrm{A}$ \\
\hline C. SITE INSPECTION (To be completed during inspection) & YES & No & EXPLANATION \\
\hline \multicolumn{4}{|l|}{ 1. Adjacent off-site features within watershed areas. } \\
\hline a. Have there been any changes in use of adjacent area? & & $\mathrm{X}$ & \\
\hline b. Are there any new roads or trails? & & $\mathrm{x}$ & \\
\hline c. Has there been a change in the position of nearby washes? & & $\mathrm{x}$ & \\
\hline $\begin{array}{l}\text { d. Has there been lateral excursion or erosion/deposition of nearby } \\
\text { washes? }\end{array}$ & & $\mathrm{x}$ & \\
\hline e. Are there new drainage channels? & & $\mathbf{X}$ & \\
\hline f. Change in surrounding vegetation? & 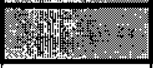 & $\mathrm{X}$ & \\
\hline \multicolumn{4}{|l|}{ 2. Security fence, signs. } \\
\hline $\begin{array}{l}\text { a. Displacement of fences, site markers, boundary markers, or } \\
\text { monuments? }\end{array}$ & & $\mathrm{x}$ & \\
\hline $\begin{array}{l}\text { b. Have any signs been damaged garemoved? } \\
\text { (Number of signs replaced: }\end{array}$ & 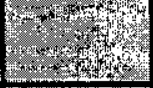 & $\mathrm{x}$ & \\
\hline c. Were gates locked? & & $\mathrm{x}$ & N/A \\
\hline
\end{tabular}




\section{CAU 426: CACTUS SPRING WASTE TRENCHES, POST-CLOSURE INSPECTION CHECKLIST}

\begin{tabular}{|c|c|c|c|}
\hline 3. Waste Unit cover. & YES & $\mathrm{NO}$ & EXPLANATION \\
\hline Is there evidence of settling? & Menes & $\mathrm{X}$ & \\
\hline b. Is there cracking? & Kx & $\mathrm{X}$ & \\
\hline c. Is there evidence of erosion around the cap (wind or water)? & W & $\mathrm{X}$ & \\
\hline d. Is there evidence of animal burrowing? & $\mathrm{X}$ & (x) & $\begin{array}{l}\text { Small burrows around the fence and margin } \\
\text { of cover, no maintenance needed. }\end{array}$ \\
\hline $\begin{array}{l}\text { Have the site markers been disturbed by man or natural } \\
\text { processes? }\end{array}$ & (6) & $\mathrm{X}$ & \\
\hline $\begin{array}{l}\text { f. Do natural processes threaten to integrity of any cover or site } \\
\text { marker? }\end{array}$ & & $\mathrm{X}$ & . \\
\hline g. Other? & & $\mathrm{X}$ & \\
\hline \multicolumn{4}{|l|}{ 4. Vegetative cover. } \\
\hline a. Is perimeter fence or mesh fencing damaged? & 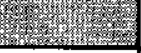 & $X$ & \\
\hline b. Is there evidence of horses or rabbits on site? & $X$ & & $\begin{array}{l}\text { Horses along fencing and rabbits/small } \\
\text { animal burrows along and within fencing. }\end{array}$ \\
\hline c. Is organic mulch and/or plants adequate to prevent erosion? & $\mathrm{X}$ & & \\
\hline d. Are weedy annual plants present? If yes, are they a problem? & $\mathrm{X}$ & & $\begin{array}{l}\text { Some are present but no maintenance } \\
\text { needed. }\end{array}$ \\
\hline e. Are seeded plant species found on site? & $\mathrm{X}$ & & \\
\hline f. Is there evidence of plant mortality? & & $\mathrm{X}$ & \\
\hline \multicolumn{4}{|l|}{ 5. Photo Documentation } \\
\hline a. Has a photo $\log$ been prepared? & $\mathrm{X}$ & & \\
\hline b. Number of photos exposed (7) & & & \\
\hline \multicolumn{4}{|l|}{ D. FIELD CONCLUSIONS } \\
\hline $\begin{array}{l}\text { 1. Is there an imminent hazard to the integrity of the unit? (Immediate report } \\
\text { required) }\end{array}$ & & $\mathrm{X}$ & \\
\hline \multicolumn{4}{|l|}{ Person/Agency to whom report made: } \\
\hline 2. Are more frequent inspections required? & & $\mathrm{X}$ & \\
\hline 3. Are existing maintenance/repair actions satisfactory? & $\mathrm{X}$ & (x) & \\
\hline 4. Is other maintenance/repair necessary? & Hinty & $\mathrm{X}$ & \\
\hline 5. Is current status/condition of vegetative cover satisfactory? & & $\mathrm{X}$ & \\
\hline
\end{tabular}

6. Rationale for field conclusions: The site is in good condition and there was no damage to the fencing or cover noted during the inspection. Some small animal burrows were noted during the inspection but no maintenance/repairs are needed.

\section{E. CERTIFICATION}

I have conducted an inspection of the Cactus Spring Waste Trenches, CAU 426, at the TTR in accordance with the Post-Closure Monitoring Plan (see Closure Report) as recorded on this chegklist, attached sheets, field notes, photo logs, and photographs.

Chief Inspector's Signature:

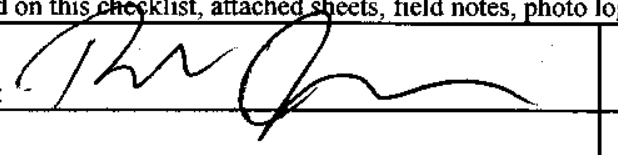

Printed Name: Brad Jackson

Title: TTR PCI Task Manager

Date: 02 June 2005 


\section{CAU 427: AREA 3 SEPTIC WASTE SYSTEMS 2 \& 6, POST-CLOSURE INSPECTION CHECKLIST}

Inspection Date: 02 June 2005

Responsible Agency: NNSA/NSO ER

Date of Last Inspection: 09 November 2004

NNSA Project Manager: Kevin Cabble

Inspector (name, title, organization): Brad Jackson BNER

Assistant Inspector (name, title, organization): N/A

\section{A. GENERAL INSTRUCTIONS}

1. All checklist items must be completed and detailed comments made to document the results of the site inspection. The completed checklist is part of the field record of the inspection. Additional pages should be used as necessary to ensure that a complete record is provided. Attach the additional pages and number all pages upon completion of the inspection.

2. Any checklist line item marked by an inspector in a SHADED BOX, must be fully explained or an appropriate reference to previous reports provided. The purpose of this requirement is to provide a written explanation of inspector observations and the inspector's rationale for conclusions and recommendations. Explanations are to be placed on additional attachments and cross-referenced appropriately. Explanations, in addition to narrative, will take the form of sketches, measurements, and annotated site maps.

3. The site inspection is a walking inspection of the entire site including the perimeter and sufficient transects to be able to examine the entire surface and all features specifically described in the checklist.

4. A standard set of color $35 \mathrm{~mm}$ photographs (or equivalent) is required. In addition, all anomalous features or new features (such as changes in adjacent area land use) are to be photographed. A photo log entry will be made for each photograph taken.

5. This unit will be inspected biannually with formal reporting to the Nevada Division of Environmental Protection to be done annually. The annual report will include an executive summary, this inspection checklist with field notes and photo log attached, and recommendations and conclusions.

\begin{tabular}{|c|c|c|c|}
\hline B. PREPARATION (To be completed prior to site visit) & YES & NO & EXPLANATION \\
\hline 1. Site as-built plans and site base map reviewed. & $\mathrm{x}$ & 40 & \\
\hline 2. Previous inspection reports reviewed. & $\mathrm{X}$ & 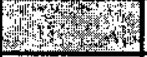 & \\
\hline a. Were anomalies or trends detected on previous inspections? & W & $\mathrm{X}$ & \\
\hline b. Was maintenance performed? & (3) & $\mathrm{X}$ & \\
\hline 3. Site maintenance and repair records reviewed. & $X$ & Hot & \\
\hline a. Has site repair resulted in a change from as-built conditions? & 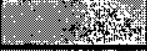 & $\mathrm{X}$ & \\
\hline b. Are revised as-builts available that reflect repair changes? & 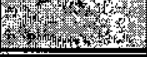 & $\mathrm{X}$ & N/A \\
\hline C. SITE INSPECTION (To be completed during inspection) & YES & NO & EXPLANATION \\
\hline \multicolumn{4}{|l|}{ 1. Adjacent off-site features within watershed areas. } \\
\hline a. Have there been any changes in use of adjacent area? & Mex & $\mathrm{X}$ & \\
\hline b. Are there any new roads or trails? & H & $\mathrm{X}$ & \\
\hline \multicolumn{4}{|l|}{ 2. Security signs. } \\
\hline $\begin{array}{l}\text { a. Displacement of site markers, boundary markers, or monuments? } \\
\text { (disturbed by man or natural processes?) }\end{array}$ & 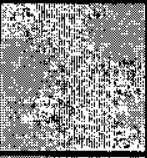 & $\mathrm{X}$ & $\begin{array}{l}\text { Some red rock covering the leachfield } \\
\text { markers has been covered. The locations } \\
\text { were found and red rock was added to aid in } \\
\text { future inspections. }\end{array}$ \\
\hline $\begin{array}{l}\text { b. Have any signs been damaged ofremoved? } \\
\text { (Number of signs replaced: }\end{array}$ & 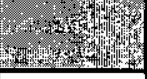 & $\mathrm{x}$ & \\
\hline $\begin{array}{l}\text { c. Were all subsurface markers detected? (i.e., using a magnetometer } \\
\text { or equivalent) }\end{array}$ & $\mathrm{x}$ & 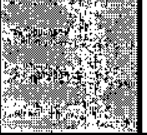 & $\begin{array}{l}\text { Markers have been located using a } \\
\text { magnetometer/excavation. Red rock was } \\
\text { used to backfill each location to aid in } \\
\text { finding markers during site inspections. }\end{array}$ \\
\hline
\end{tabular}




\begin{tabular}{|c|c|c|c|}
\hline 3. Soil/asphalt cover. & YES & No & EXPLANATION \\
\hline a. Is there evidence of settling? & 2. & $\mathrm{X}$ & \\
\hline b. Is there cracking? & W1 & $\mathrm{X}$ & \\
\hline c. Is there evidence of erosion near use restriction boundaries? & 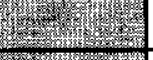 & $\mathrm{X}$ & \\
\hline d. Is there evidence of animal burrowing? & 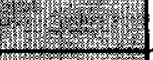 & $\mathrm{X}$ & \\
\hline e. Is there vegetation? & Wexy & $\mathrm{X}$ & \\
\hline $\begin{array}{l}\text { f. Do natural processes threaten to integrity of any cover or site } \\
\text { marker? }\end{array}$ & mity & $\mathrm{X}$ & \\
\hline $\begin{array}{l}\text { g. Is there evidence suggesting unauthorized excavations have taken } \\
\text { place? }\end{array}$ & 3.t. & $\mathrm{X}$ & \\
\hline e. Other? & (2) & $\mathrm{x}$ & . \\
\hline \multicolumn{4}{|l|}{ 4. Photo Documentation } \\
\hline a. Has a photo $\log$ been prepared? & $\mathrm{X}$ & 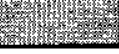 & \\
\hline b. Number of photos exposed (14) & & & \\
\hline \multicolumn{4}{|l|}{ D. FIELD CONCLUSIONS } \\
\hline $\begin{array}{l}\text { 1: Is there an imminent hazard to the integrity of the unit? (Immediate report } \\
\text { required) }\end{array}$ & & $\mathrm{X}$ & \\
\hline \multicolumn{4}{|l|}{ Person/Agency to whom report made: } \\
\hline 2. Are more frequent inspections required? & $\sqrt{3}$ & $x$ & \\
\hline 3. Are existing maintenance/repair actions satisfactory? & $\mathrm{X}$ & 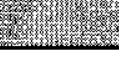 & \\
\hline 4. Is other maintenance/repair necessary? & 42 & $\mathrm{X}$ & \\
\hline \multicolumn{4}{|c|}{$\begin{array}{l}\text { 5. Rationale for field conclusions: The site is in good condition and no maintenance/repairs are needed. Two marker locations were obscured by fill } \\
\text { material but were uncovered and repaired at the time of the inspection. }\end{array}$} \\
\hline \multicolumn{4}{|l|}{ E. CERTIFICATION } \\
\hline \multicolumn{4}{|c|}{$\begin{array}{l}\text { I have conducted an inspection of the Area } 3 \text { Septic Waste Systems } 2 \& 6, \mathrm{CAU} 427 \text {, at the TTR in accordance with the Post-Closure Monitoring Plan } \\
\text { (see Closure Report) as recorded on this checklist, attached sheets, field notes, photo logs, and photographs. }\end{array}$} \\
\hline Chief Inspector's Signature: ${ }^{2}$ & \multicolumn{3}{|c|}{ Printed Name: Brad Jackson } \\
\hline Title: TTR PCI Task Manager & \multicolumn{3}{|c|}{ Date: 02 June 2005} \\
\hline
\end{tabular}




\section{CAU 453: AREA 9 UXO LANDFILL, POST-CLOSURE INSPECTION CHECKLIST}

Inspection Date: 02 June 2005

Responsible Agency: NNSA/NSO ER

NNSA Project Manager: Kevin Cabble

Date of Last Inspection: 10 November 2004

Reason for Last Inspection: Semiannual inspection

Inspector (name, title, organization): Brad Jackson BNER

Assistant Inspector (name, title, organization): N/A

\section{A. GENERAL INSTRUCTIONS}

1. All checklist items must be completed and detailed comments made to document the results of the site inspection. The completed checklist is part of the field record of the inspection. Additional pages should be used as necessary to ensure that a complete record is provided. Attach the additional pages and number all pages upon completion of the inspection.

2. Any checklist line item marked by an inspector in a SHADED BOX, must be fully explained or an appropriate reference to previous reports provided. The purpose of this requirement is to provide a written explanation of inspector observations and the inspector's rationale for conclusions and recommendations. Explanations are to be placed on additional attachments and cross-referenced appropriately.

Explanations, in addition to narrative, will take the form of sketches, measurements, and annotated site maps.

3. The site inspection is a walking inspection of the entire site including the perimeter and sufficient transects to be able to examine the entire surface and all features specifically described in the checklist.

4. A standard set of color $35 \mathrm{~mm}$ photographs (or equivalent) is required. In addition, all anomalous features or new features (such as changes in adjacent area land use) are to be photographed. A photo log entry will be made for each photograph taken.

5. This unit will be inspected biannually with formal reporting to the Nevada Division of Environmental Protection to be done annually. The annual report will include an executive summary, this inspection checklist with field notes and photo log attached, and recommendations and conclusions.

\begin{tabular}{|c|c|c|c|}
\hline B. PREPARATION (To be completed prior to site visit) & YES & No & EXPLANATION \\
\hline 1. Site as-built plans and site base map reviewed. & 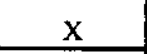 & 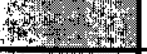 & \\
\hline 2. Previous inspection reports reviewed. & $\mathrm{X}$ & 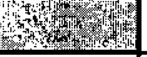 & \\
\hline a. Were anomalies or trends detected on previous inspections? & 1.4. & $\mathrm{X}$ & \\
\hline b. Was maintenance performed? & 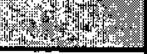 & $\mathrm{X}$ & \\
\hline 3. Site maintenance and repair records reviewed. & $\mathrm{X}$ & 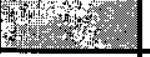 & \\
\hline a. Has site repair resulted in a change from as-built conditions? & 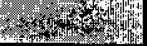 & X & \\
\hline b. Are revised as-builts available that reflect repair changes? & 3. & $\mathbf{X}$ & $\mathrm{N} / \mathrm{A}$ \\
\hline C. SITE INSPECTION (To be completed during inspection) & YES & NO & EXPLANATION \\
\hline \multicolumn{4}{|l|}{ 1. Adjacent off-site features within watershed areas. } \\
\hline a. Have there been any changes in use of adjacent area? & 3tidy & $\mathrm{X}$ & \\
\hline b. Are there any new roads or trails? & 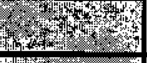 & $\mathrm{X}$ & \\
\hline c. Has there been a change in the position of nearby washes? & 4 (6) & $\mathrm{X}$ & \\
\hline $\begin{array}{l}\text { d. Has there been lateral excursion or erosion/deposition of nearby } \\
\text { washes? }\end{array}$ & (1) & $\mathrm{X}$ & \\
\hline e. Are there new drainage channels? & - & $\underline{X}$ & \\
\hline f. Change in surrounding vegetation? & 78. & $\mathrm{X}$ & \\
\hline \multicolumn{4}{|l|}{ 2. Security fence, signs. } \\
\hline $\begin{array}{l}\text { a. Displacement of fences, site markers, boundary markers, or } \\
\text { monuments? }\end{array}$ & W & $\mathrm{X}$ & \\
\hline $\begin{array}{l}\text { b. Have any signs been damaged } \mathcal{H}^{\text {emoved? }} \\
\text { (Number of signs replaced: }\end{array}$ & 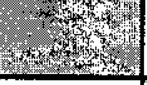 & $\mathrm{x}$ & \\
\hline c. Were gates locked? & $x$ & Hox & New lock placed by ASI \\
\hline
\end{tabular}




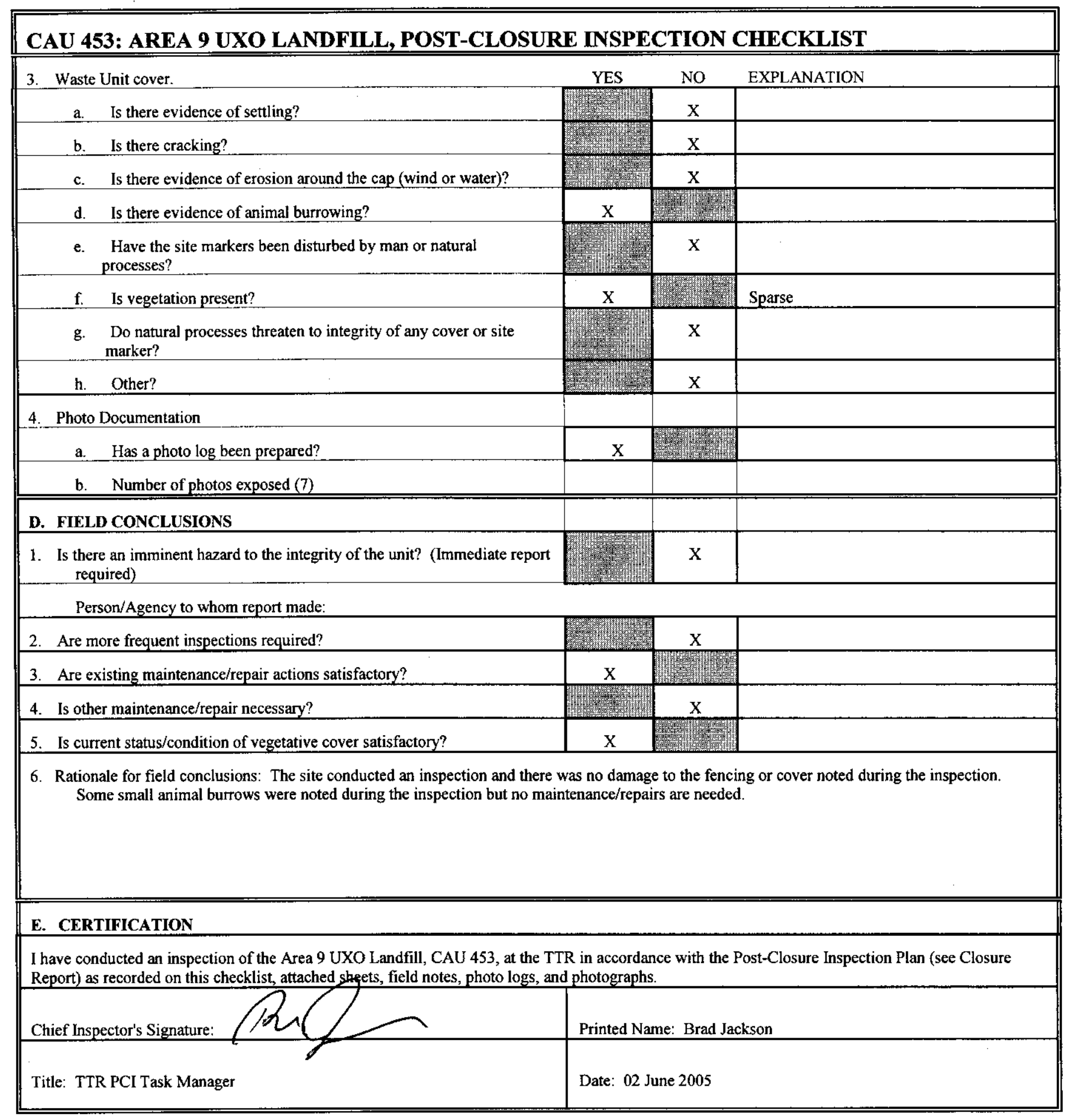




\section{CAU 487: THUNDERWELL SITE, POST-CLOSURE INSPECTION CHECKLIST}

\begin{tabular}{||l|l|}
\hline Inspection Date: 02 June 2005 & \\
\hline Responsible Agency: NNSA/NSO ER & NNSA Project Manager: Kevin Cabble \\
\hline Date of Last Inspection: 10 November 2004 & Reason for Last Inspection: Semiannual inspection \\
\hline Inspector (name, title, organization): Brad Jackson BNER \\
\hline Assistant Inspector (name, title, organization): N/A
\end{tabular}

\section{A. GENERAL INSTRUCTIONS}

1. All checklist items must be completed and detailed comments made to document the results of the site inspection. The completed checklist is part of the field record of the inspection. Additional pages should be used as necessary to ensure that a complete record is provided. Attach the additional pages and number all pages upon completion of the inspection.

2. Any checklist line item marked by an inspector in a SHADED BOX, must be fully explained or an appropriate reference to previous reports provided. The purpose of this requirement is to provide a written explanation of inspector observations and the inspector's rationale for conclusions and recommendations. Explanations are to be placed on additional attachments and cross-referenced appropriately. Explanations, in addition to narrative, will take the form of sketches, measurements, and annotated site maps

3. The site inspection is a walking inspection of the entire site including the perimeter and sufficient transects to be able to examine the entire surface and all features specifically described in the checklist.

4. A standard set of color $35 \mathrm{~mm}$ photographs (or equivalent) is required. In addition, all anomalous features or new features (such as changes in adjacent area land use) are to be photographed. A photo log entry will be made for each photograph taken.

5. This unit will be inspected biannually with formal reporting to the Nevada Division of Environmental Protection to be done annually. The annual report will include an executive summary, this inspection checklist with field notes and photo log attached, and recommendations and conclusions.

\begin{tabular}{|c|c|c|c|}
\hline B. PREPARATION (To be completed prior to site visit) & YES & NO & EXPLANATION \\
\hline 1. Site as-built plans and site base map reviewed. & $\mathrm{X}$ & $y^{2}$ & \\
\hline 2. Previous inspection reports reviewed. & $\mathrm{X}$ & W & \\
\hline a. Were anomalies or trends detected on previous inspections? & & $\mathbf{X}$ & \\
\hline b. Was maintenance performed? & 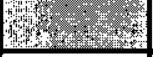 & $\mathbf{X}$ & \\
\hline 3. Site maintenance and repair records reviewed. & $\mathbf{X}$ & $\begin{array}{l}3+5 \\
3\end{array}$ & \\
\hline a. Has site repair resulted in a change from as-built conditions? & 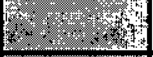 & $\mathrm{X}$ & \\
\hline b. Are revised as-builts available that reflect repair changes? & 30 & $\mathrm{X}$ & N/A \\
\hline C. SITE INSPECTION (To be completed during inspection) & YES & NO & EXPLANATION \\
\hline \multicolumn{4}{|l|}{ 1. Adjacent off-site features within watershed areas. } \\
\hline a. Have there been any changes in use of adjacent area? & $y_{3}^{2}$ & $\mathrm{X}$ & \\
\hline b. Are there any new roads or trails? & & $\mathbf{X}$ & \\
\hline c. Has there been a change in the position of nearby washes? & & $\mathrm{x}$ & \\
\hline $\begin{array}{l}\text { d. Has there been lateral excursion or erosion/deposition of nearby } \\
\text { washes? }\end{array}$ & 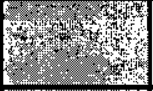 & $\mathrm{X}$ & \\
\hline e. Are there new drainage channels? & $\begin{aligned}-4 \\
\end{aligned}$ & $\mathrm{X}$ & \\
\hline f. Change in surrounding vegetation? & 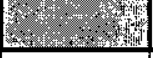 & $\underline{X}$ & \\
\hline \multicolumn{4}{|l|}{ 2. Security fence, signs. } \\
\hline $\begin{array}{l}\text { a. Displacement of fences, site markers, boundary markers, or } \\
\text { monuments? }\end{array}$ & Fing & $\mathbf{X}$ & \\
\hline $\begin{array}{l}\text { b. Have any signs been damaged } \\
\text { (Number of signs replaced:_ }\end{array}$ & $\begin{array}{r}4 \\
4 \\
4\end{array}$ & $\mathbf{X}$ & \\
\hline
\end{tabular}




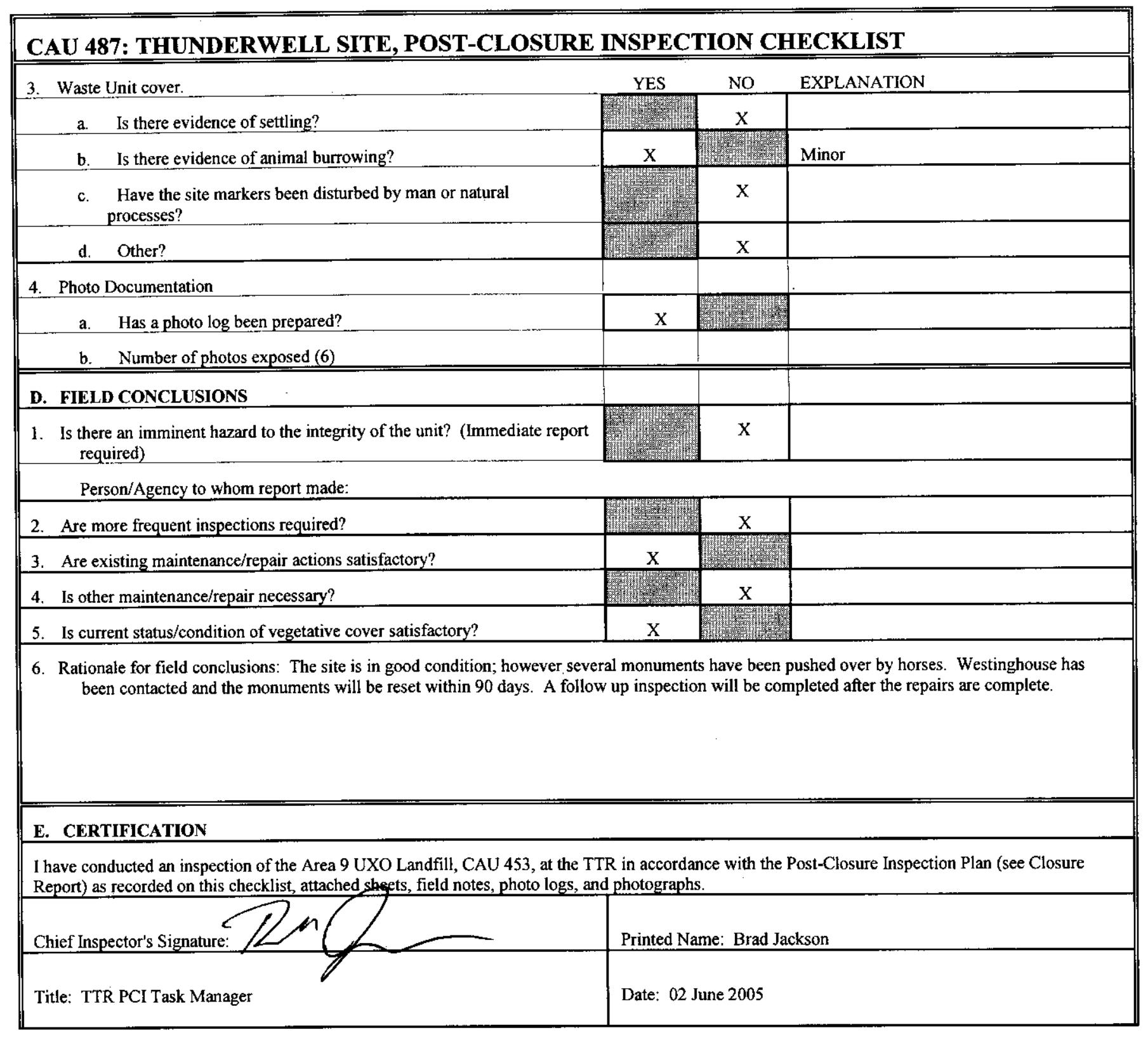


CAU 400: 5 POINTS LANDFILL, POST-CLOSURE INSPECTION CHECKLIST

Inspection Date: 15 November 2005

Responsible Agency: NNSA/NSO ER NNSA Project Manager: Kevin Cabble

Date of Last Inspection: 1 June 2005

Reason for Last Inspection: Semiannual inspection

Inspector (name, title, organization): Brad Jackson BNER

Assistant Inspector (name, title, organization): N/A

A. GENERAL INSTRUCTIONS

1. All checklist items must be completed and detailed comments made to document the results of the site inspection. The completed checklist is part of the field record of the inspection. Additional pages should be used as necessary to ensure that a complete record is provided. Attach the additional pages and number all pages upon completion of the inspection.

2. Any checklist line item marked by an inspector in a SHADED BOX, must be fully explained or an appropriate reference to previous reports provided. The purpose of this requirement is to provide a written explanation of inspector observations and the inspector's rationale for conclusions and recommendations. Explanations are to be placed on additional attachments and cross-referenced appropriately. Explanations, in addition to narrative, will take the form of sketches, measurements, and annotated site maps.

3. The site inspection is a walking inspection of the entire site including the perimeter and sufficient transects to be able to examine the entire surface and all features specifically described in the checklist.

4. A standard set of color $35 \mathrm{~mm}$ photographs (or equivalent) is required. In addition, all anomalous features or new features (such as changes in adjacent area land use) are to be photographed. A photo log entry will be made for each photograph taken.

5. This unit will be inspected biannually with formal reporting to the Nevada Division of Environmental Protection to be done annually. The annual report will include an executive summary, this inspection checklist with field notes and photo log attached, and recommendations and conclusions.

\begin{tabular}{|c|c|c|c|}
\hline B. PREPARATION (To be completed prior to site visit) & YES & NO & EXPLANATION \\
\hline 1. Site as-built plans and site base map reviewed. & $\mathrm{X}$ & 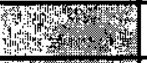 & \\
\hline 2. Previous inspection reports reviewed. & $\mathrm{X}$ & 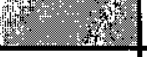 & \\
\hline a. Were anomalies or trends detected on previous inspections? & 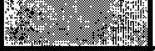 & $\mathrm{X}$ & \\
\hline b. Was maintenance performed? & (6) & $\mathrm{X}$ & \\
\hline 3. Site maintenance and repair records reviewed. & $\mathrm{X}$ & 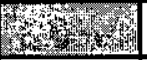 & \\
\hline a. Has site repair resulted in a change from as-built conditions? & 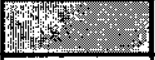 & $\mathbf{x}$ & \\
\hline b. Are revised as-builts available that reflect repair changes? & & 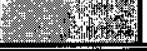 & $\mathrm{N} / \mathrm{A}$ \\
\hline C. SITE INSPECTION (To be completed during inspection) & YES & NO & EXPLANATION \\
\hline \multicolumn{4}{|l|}{ 1. Adjacent off-site features within watershed areas. } \\
\hline a. Have there been any changes in use of adjacent area? & & $\mathrm{X}$ & \\
\hline b. Are there any new roads or trails? & & $\underline{X}$ & \\
\hline c. Has there been a change in the position of nearby washes? & & $\mathrm{X}$ & \\
\hline $\begin{array}{l}\text { d. Has there been lateral excursion or erosion/deposition of nearby } \\
\text { washes? }\end{array}$ & 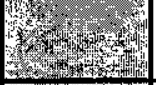 & $\mathrm{x}$ & \\
\hline e. Are there new drainage channels? & Y. & $\underline{X}$ & \\
\hline f. Change in surrounding vegetation? & 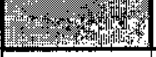 & $\mathbf{x}$ & \\
\hline \multicolumn{4}{|l|}{ 2. Security fence, signs. } \\
\hline $\begin{array}{l}\text { a. Displacement of fences, site markers, boundary markers, or } \\
\text { monuments? }\end{array}$ & 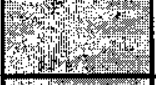 & $\mathbf{x}$ & \\
\hline $\begin{array}{l}\text { b. Have any signs been damaged of removed? } \\
\text { (Number of signs replaced: }\end{array}$ & 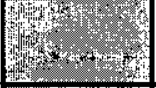 & $\mathrm{x}$ & \\
\hline c. Were gates locked? & 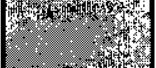 & $\mathrm{X}$ & Not required \\
\hline
\end{tabular}




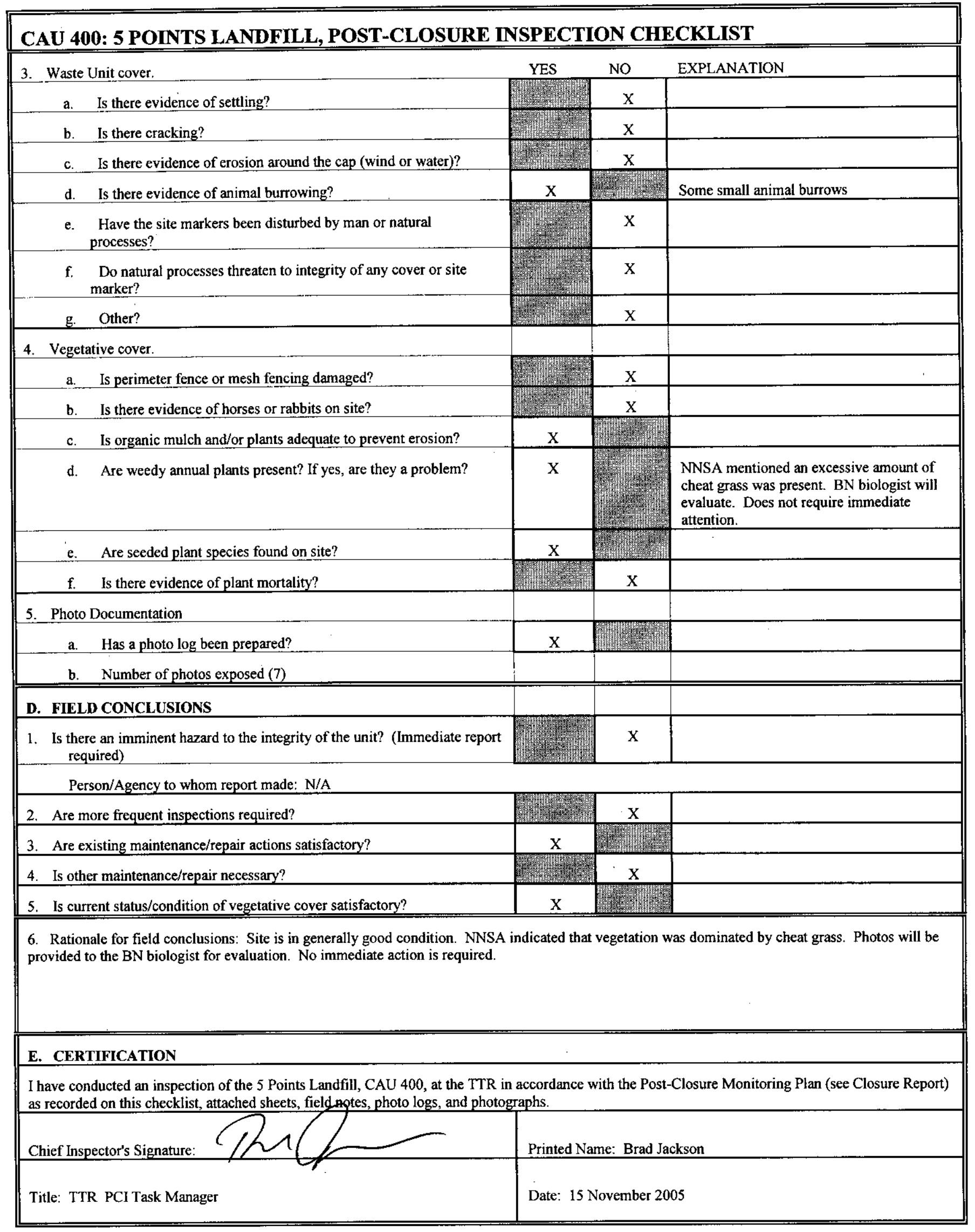




\section{CAU 400: BOMBLET PIT, POST-CLOSURE INSPECTION CHECKLIST}

Inspection Date: 15 November 2005

Responsible Agency: NNSA/NSO ER

NNSA Project Manager: Kevin Cabble

Date of Last Inspection: 01 June 2005

Reason for Last Inspection: Semiannual inspection

Inspector (name, title, organization): Brad Jackson BNER

Assistant Inspector (name, title, organization): N/A

\section{A. GENERAL INSTRUCTIONS}

1. All checklist items must be completed and detailed comments made to document the results of the site inspection. The completed checklist is part of the field record of the inspection. Additional pages should be used as necessary to ensure that a complete record is provided. Attach the additional pages and number all pages upon completion of the inspection.

2. Any checklist line item marked by an inspector in a SHADED BOX, must be fully explained or an appropriate reference to previous reports provided. The purpose of this requirement is to provide a written explanation of inspector observations and the inspector's rationale for conclusions and recommendations. Explanations are to be placed on additional attachments and cross-referenced appropriately. Explanations, in addition to narrative, will take the form of sketches, measurements, and annotated site maps.

3. The site inspection is a walking inspection of the entire site including the perimeter and sufficient transects to be able to examine the entire surface and all features specifically described in the checklist.

4. A standard set of color $35 \mathrm{~mm}$ photographs (or equivalent) is required. In addition, all anomalous features or new features (such as changes in adjacent area land use) are to be photographed. A photo log entry will be made for each photograph taken.

5. This unit will be inspected biannually with formal reporting to the Nevada Division of Environmental Protection to be done annually. The annual report will include an executive summary, this inspection checklist with field notes and photo log attached, and recommendations and conclusions.

\begin{tabular}{|c|c|c|c|}
\hline B. PREPARATION (To be completed prior to site visit) & YES & NO & EXPLANATION \\
\hline 1. Site as-built plans and site base map reviewed. & $\underline{x}$ & $x_{3}=x+2 x$ & \\
\hline 2. Previous inspection reports reviewed. & $\mathrm{X}$ & - & \\
\hline a. Were anomalies or trends detected on previous inspections? & & $\mathrm{x}$ & \\
\hline b. Was maintenance performed? & & $\mathrm{X}$ & \\
\hline 3. Site maintenance and repair records reviewed. & $\mathrm{X}$ & Mras & \\
\hline a. Has site repair resulted in a change from as-built conditions? & & $\mathrm{x}$ & \\
\hline b. Are revised as-builts available that reflect repair changes? & & 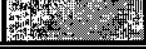 & N/A \\
\hline C. SITE INSPECTION (To be completed during inspection) & YES & NO & EXPLANATION \\
\hline \multicolumn{4}{|l|}{ 1. Adjacent off-site features within watershed areas. } \\
\hline a. Have there been any changes in use of adjacent area? & (x) & $\underline{X}$ & \\
\hline b. Are there any new roads or trails? & & $\mathrm{X}$ & \\
\hline c. Has there been a change in the position of nearby washes? & & $\mathrm{X}$ & \\
\hline $\begin{array}{l}\text { d. Has there been lateral excursion or erosion/deposition of nearby } \\
\text { washes? }\end{array}$ & $\sin _{10}$ & $\mathrm{X}$ & \\
\hline e. Are there new drainage channels? & 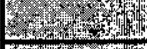 & $\mathrm{x}$ & \\
\hline f. Change in surrounding vegetation? & ty & $\mathrm{X}$ & \\
\hline \multicolumn{4}{|l|}{ 2. Security fence, signs. } \\
\hline $\begin{array}{l}\text { a. Displacement of fences, site markers, boundary markers, or } \\
\text { monuments? }\end{array}$ & & $\mathbf{X}$ & All fencing is in good condition \\
\hline $\begin{array}{l}\text { b. Have any signs been damagegor removed? } \\
\text { (Number of signs replaced: }\end{array}$ & 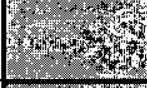 & $\mathrm{X}$ & \\
\hline c. Were gates locked? & & $\mathrm{x}$ & Not required \\
\hline
\end{tabular}




\section{CAU 400: BOMBLET PIT, POST-CLOSURE INSPECTION CHECKLIST}

3. Waste Unit cover

YES

a. Is there evidence of settling?

b. Is there cracking?

c. Is there evidence of erosion around the cap (wind or water)?

d. Is there evidence of animal burrowing?

e. Have the site markers been disturbed by man or natural processes?

f. Do natural processes threaten to integrity of any cover or site marker?

g. Other?

4. Vegetative cover.

a. Is perimeter fence or mesh fencing damaged?

b. Is there evidence of horses or rabbits on site?

c. Is organic mulch and/or plants adequate to prevent erosion?

d. Are weedy annual plants present? If yes, are they a problem?

e. Are seeded plant species found on site?

f. Is there evidence of plant mortality?

5. Photo Documentation

a. Has a photo $\log$ been prepared?

b. Number of photos exposed (7)

\section{FIELD CONCLUSIONS}

1. Is there an imminent hazard to the integrity of the unit? (Immediate report required)

Person/Agency to whom report made:

2. Are more frequent inspections required?

3. Are existing maintenance/repair actions satisfactory?

4. Is other maintenance/repair necessary?

5. Is current status/condition of vegetative cover satisfactory?

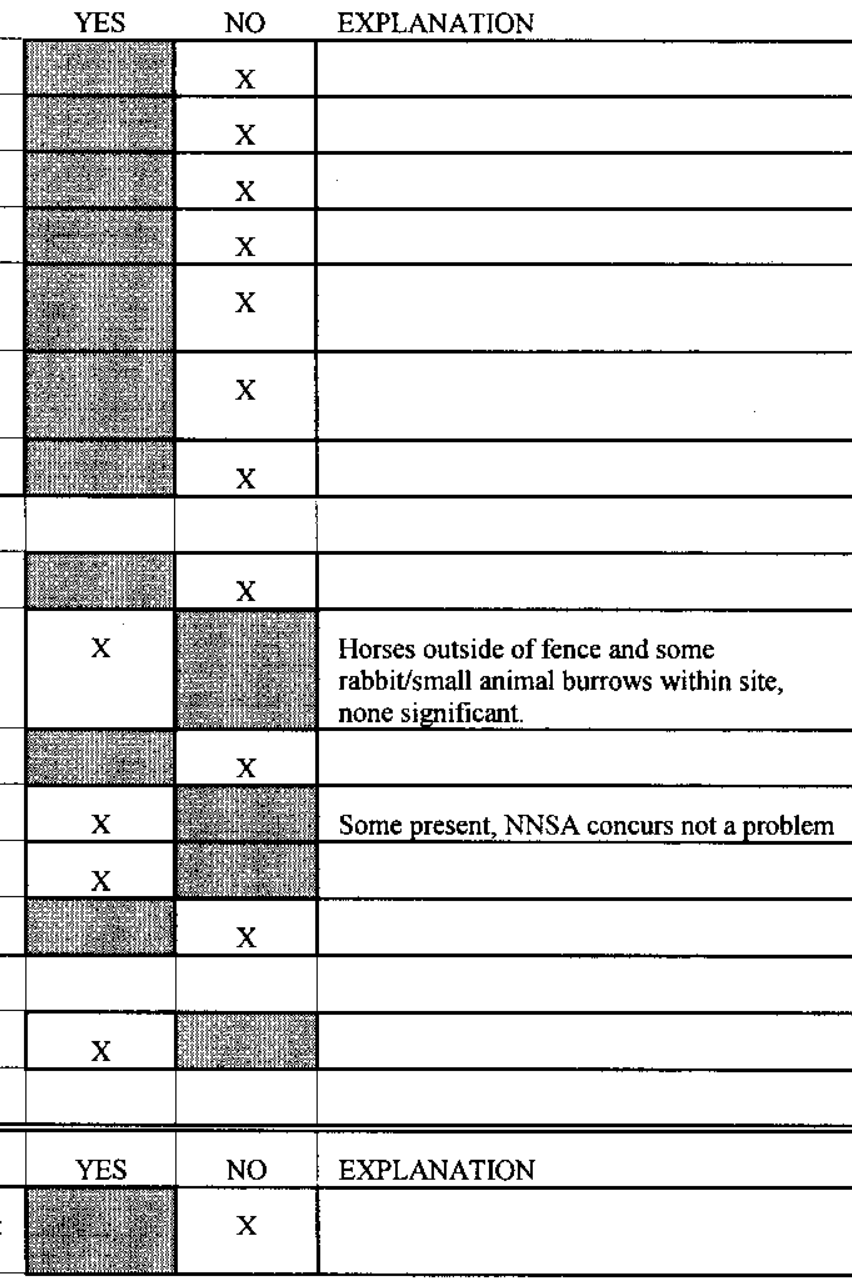

6. Rationale for field conclusions: The site is in good condition and no maintenance/repairs are needed. Inspections are not required at this site but are completed as a best management practice under NNSA approval.

\section{E. CERTIFICATION}

I have conducted an inspection of the Bomblet Pit, CAU 400, at the TTR in accordance with the Post-Closure Monitoring Plan (see Closure Report) as recorded on this checklist, attached sheets, field noterg photo logs, and photographs.

Chief Inspector's Signature:

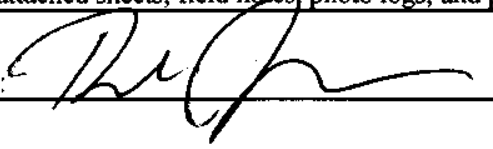

Title: TTR PCI Task Manger

\begin{tabular}{|c|c|l||}
\hline & $x$ & \\
\hline$x$ & & \\
\hline & $x$ & \\
\hline & $x$ & \\
\hline & & \\
\hline
\end{tabular}

Date: 15 November 2005 


\section{CAU 404: ROLLER COASTER LAGOONS \& N. DISPOSAL TRENCH, POST-CLOSURE MONITORING CHECKLIST}

Inspection Date: 15 November 2005

Responsible Agency: NNSA/NSO ER

NNSA Project Manager: Kevin Cabble

Date of Last Inspection: 01 June 2005

Reason for Last Inspection: Semiannual inspection

Inspector (name, title, organization): Brad Jackson BNER

Assistant Inspector (name, title, organization): N/A

\section{A. GENERAL INSTRUCTIONS}

1. All checklist items must be completed and detailed comments made to document the results of the site inspection. The completed checklist is part of the field record of the inspection. Additional pages should be used as necessary to ensure that a complete record is provided. Attach the additional pages and number all pages upon completion of the inspection.

2. Any checklist line item marked by an inspector in a SHADED BOX, must be fully explained or an appropriate reference to previous reports provided. The purpose of this requirement is to provide a written explanation of inspector observations and the inspector's rationale for conclusions and recommendations. Explanations are to be placed on additional attachments and cross-referenced appropriately.

Explanations, in addition to narrative, will take the form of sketches, measurements, and annotated site maps.

3. The site inspection is a walking inspection of the entire site including the perimeter and sufficient transects to be able to examine the entire surface and all features specifically described in the checklist.

4. A standard set of color $35 \mathrm{~mm}$ photographs (or equivalent) is required. In addition, all anomalous features or new features (such as changes in adjacent area land use) are to be photographed. A photo log entry will be made for each photograph taken.

5. This unit will be inspected biannually with formal reporting to the Nevada Division of Environmental Protection to be done annually. The annual report will include an executive summary, this inspection checklist with field notes and photo log attached, and recommendations and conclusions.

\begin{tabular}{|c|c|c|c|}
\hline B. PREPARATION (To be completed prior to site visit) & YES & NO & EXPLANATION \\
\hline 1. Site as-built plans and site base map reviewed. & $\mathrm{x}$ & 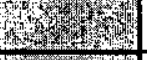 & \\
\hline 2. Previous inspection reports reviewed. & $\mathrm{X}$ & $3-x+2$ & \\
\hline a. Were anomalies or trends detected on previous inspections? & 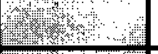 & $\mathrm{X}$ & \\
\hline b. Was maintenance performed? & & $\mathrm{X}$ & \\
\hline 3. Site maintenance and repair records reviewed. & $\mathrm{X}$ & 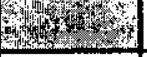 & \\
\hline a. Has site repair resulted in a change from as-built conditions? & (x) & $\mathbf{X}$ & - \\
\hline b. Are revised as-builts available that reflect repair changes? & 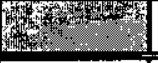 & $\mathbf{X}$ & $\mathrm{N} / \mathrm{A}$ \\
\hline C. SITE INSPECTION (To be completed during inspection) & YES & No & EXPLANATION \\
\hline \multicolumn{4}{|l|}{ 1. Adjacent off-site features within watershed areas. } \\
\hline a. Have there been any changes in use of adjacent area? & 28: & $\mathrm{X}$ & \\
\hline b. Are there any new roads or trails? & & $\mathrm{X}$ & \\
\hline c. Has there been a change in the position of nearby washes? & & $\underline{x}$ & \\
\hline $\begin{array}{l}\text { d. Has there been lateral excursion or erosion/deposition of nearby } \\
\text { washes? }\end{array}$ & & $\mathrm{x}$ & \\
\hline e. Are there new drainage channels? & 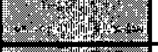 & $\mathrm{X}$ & \\
\hline f. Change in surrounding vegetation? & 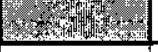 & $\underline{x}$ & \\
\hline \multicolumn{4}{|l|}{ 2. Security fence, signs. } \\
\hline $\begin{array}{l}\text { a. Displacement of fences, site markers, boundary markers, or } \\
\text { monuments? }\end{array}$ & & $\mathrm{x}$ & \\
\hline $\begin{array}{l}\text { Have any signs been damaged } \mathrm{gr}^{\mathrm{r}} \text { removed? } \\
\text { (Number of signs replaced: }\end{array}$ & (46) & $\mathrm{X}$ & \\
\hline c. Were gates locked? & 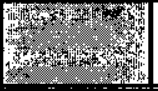 & $\mathrm{x}$ & Not required \\
\hline
\end{tabular}




\section{CAU 404: ROLLER COASTER LAGOONS \& N. DISPOSAL TRENCH, POST-CLOSURE MONITORING CHECKLIST}

3. Waste Unit cover.

a. Is there evidence of settling?

b. Is there cracking?

c. Is there evidence of erosion around the cap (wind or water)?

d. Is there evidence of animal burrowing?

e. Have the site markers been disturbed by man or natural processes?

f. Do natural processes threaten to integrity of any cover or site marker?

g. Other?

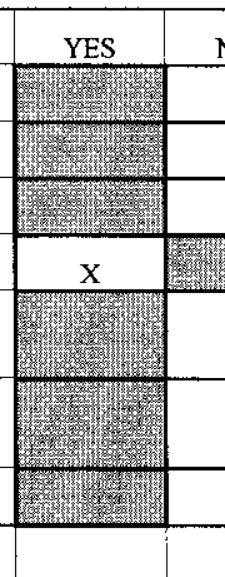

4. Vegetative cover.

a. Is perimeter fence or mesh fencing damaged?

b. Is there evidence of horses or rabbits on site?

c. Is organic mulch adequate to prevent erosion?

d. Are weedy annual plants present? If yes, are they a problem?

e. Are seeded plant species found on site?

f. Is there evidence of plant mortality?

5. Photo Documentation

a. Has a photo $\log$ been prepared?

b. Number of photos exposed (7)

\section{FIELD CONCLUSIONS}

1. Is there an imminent hazard to the integrity of the unit? (Immediate report required)

\begin{tabular}{c|l} 
NO & EXPLANATION \\
\hline $\mathrm{X}$ & \\
\hline $\mathrm{X}$ & \\
\hline $\mathrm{X}$ & \\
\hline $\mathrm{x}$ & \\
\hline
\end{tabular}

Minor, no damage or repairs needed

$\mathrm{X}$

$\mathrm{X}$

$\mathrm{X}$

Person/Agency to whom report made:

2. Are more frequent inspections required?

3. Are existing maintenance/repair actions satisfactory?

4. Is other maintenance/repair necessary?

5 . Is current status/condition of vegetative cover satisfactory?

\begin{tabular}{|c|c|l|}
\hline $\mathrm{X}$ & $\mathrm{X}$ & \\
\hline & & $\begin{array}{l}\text { Horse activity outside fence and some } \\
\text { rabbit/small animal burrows along and } \\
\text { within fence. No repairs needed. }\end{array}$ \\
\hline $\mathrm{X}$ & $\mathrm{X}$ & \\
\hline $\mathrm{X}$ & $\mathrm{X}$ & Minor, NNSA concurs not a problem \\
\hline & $\mathrm{X}$ & \\
\hline $\mathrm{X}$ & & \\
\hline & & \\
\hline & & \\
\hline
\end{tabular}

6. Rationale for field conclusions: The site is in good condition and there was no damage to the fencing or cover noted during the inspection. Some small animal burrows were noted during the inspection but no maintenance/repairs are needed.

\section{E. CERTIFICATION}

I have conducted an inspection of the Roller Coaster Sewage Lagoons \& North Disposal Trench, CAU 404, at the TTR in accordance with the PostClosure Monitoring Plan (see Closure Report) as recgded on this checklist, attached sheets, field notes, photo logs, and photographs.

Chief Inspector's Signature:

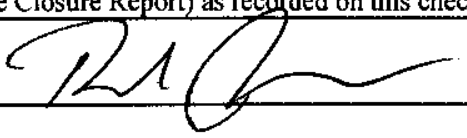
Printed Name: Brad Jackson

Title: TTR PCI Task Manager

Date: 15 November 2005 
CAU 407: ROLLER COASTER RADSAFE AREA, POST-CLOSURE INSPECTION CHECKLIST

Inspection Date: 15 November 2005

Responsible Agency: NNSA/NSO ER

NNSA Project Manager: Kevin Cabble

Date of Last Inspection: 01 June 2005

Reason for Last Inspection: Semiannual inspection

Inspector (name, title, organization): Brad Jackson BNER

Assistant Inspector (name, title, organization): N/A

A. GENERAL INSTRUCTIONS

1. All checklist items must be completed and detailed comments made to document the results of the site inspection. The completed checklist is part of the field record of the inspection. Additional pages should be used as necessary to ensure that a complete record is provided. Attach the additional pages and number all pages upon completion of the inspection.

2. Any checklist line item marked by an inspector in a SHADED BOX, must be fully explained or an appropriate reference to previous reports provided. The purpose of this requirement is to provide a written explanation of inspector observations and the inspector's rationale for conclusions and recommendations. Explanations are to be placed on additional attachments and cross-referenced appropriately.

Explanations, in addition to narrative, will take the form of sketches, measurements, and annotated site maps.

3. The site inspection is a walking inspection of the entire site including the perimeter and sufficient transects to be able to examine the entire surface and all features specifically described in the checklist.

4. A standard set of color $35 \mathrm{~mm}$ photographs (or equivalent) is required. In addition, all anomalous features or new features (such as changes in adjacent area land use) are to be photographed. A photo log entry will be made for each photograph taken.

5. This unit will be inspected biannually with formal reporting to the Nevada Division of Environmental Protection to be done annually. The annual report will include an executive summary, this inspection checklist with field notes and photo log attached, and recommendations and conclusions.

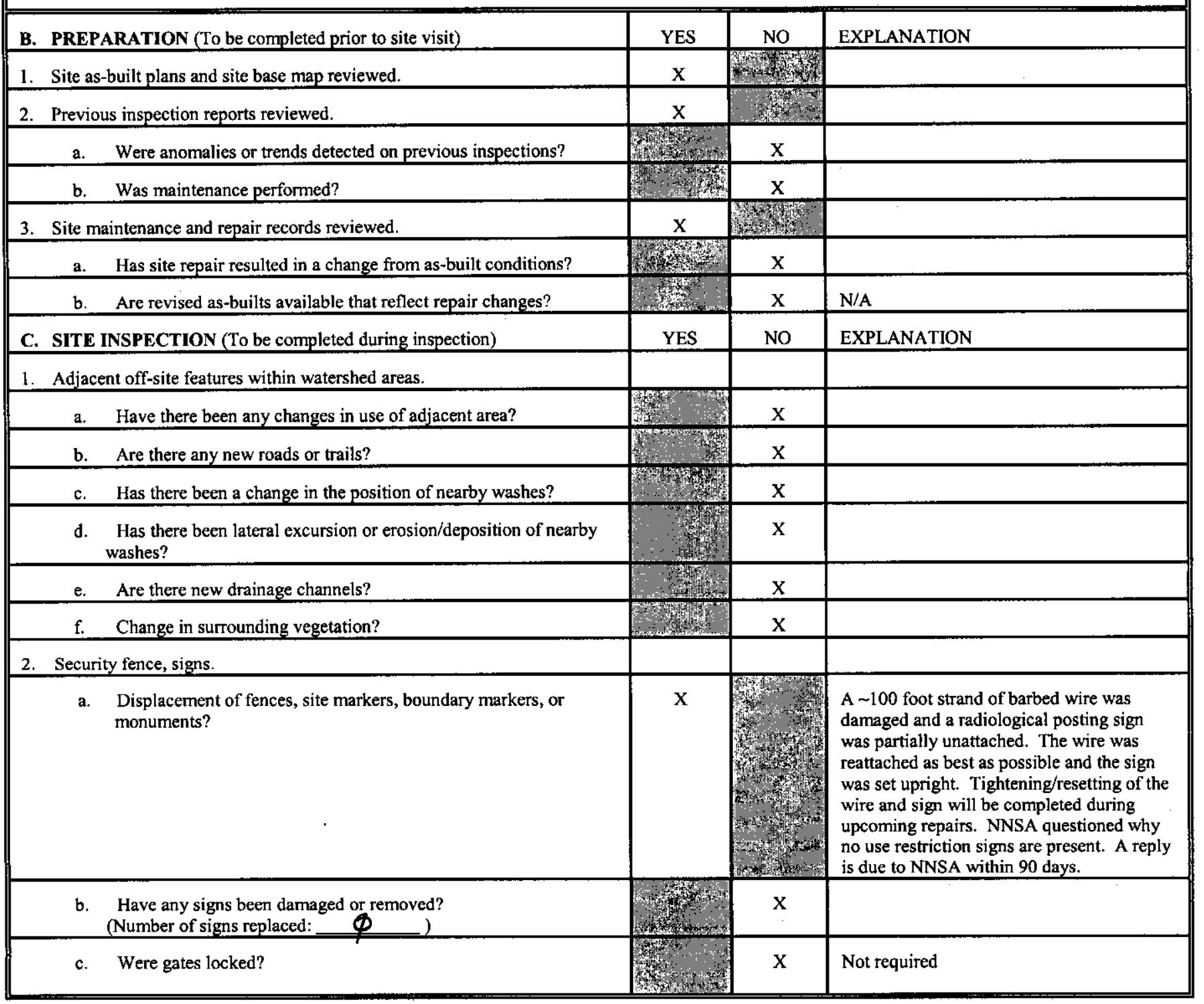




\section{CAU 407: ROLLER COASTER RADSAFE AREA, POST-CLOSURE INSPECTION CHECKLIST}

3. Waste Unit cover.

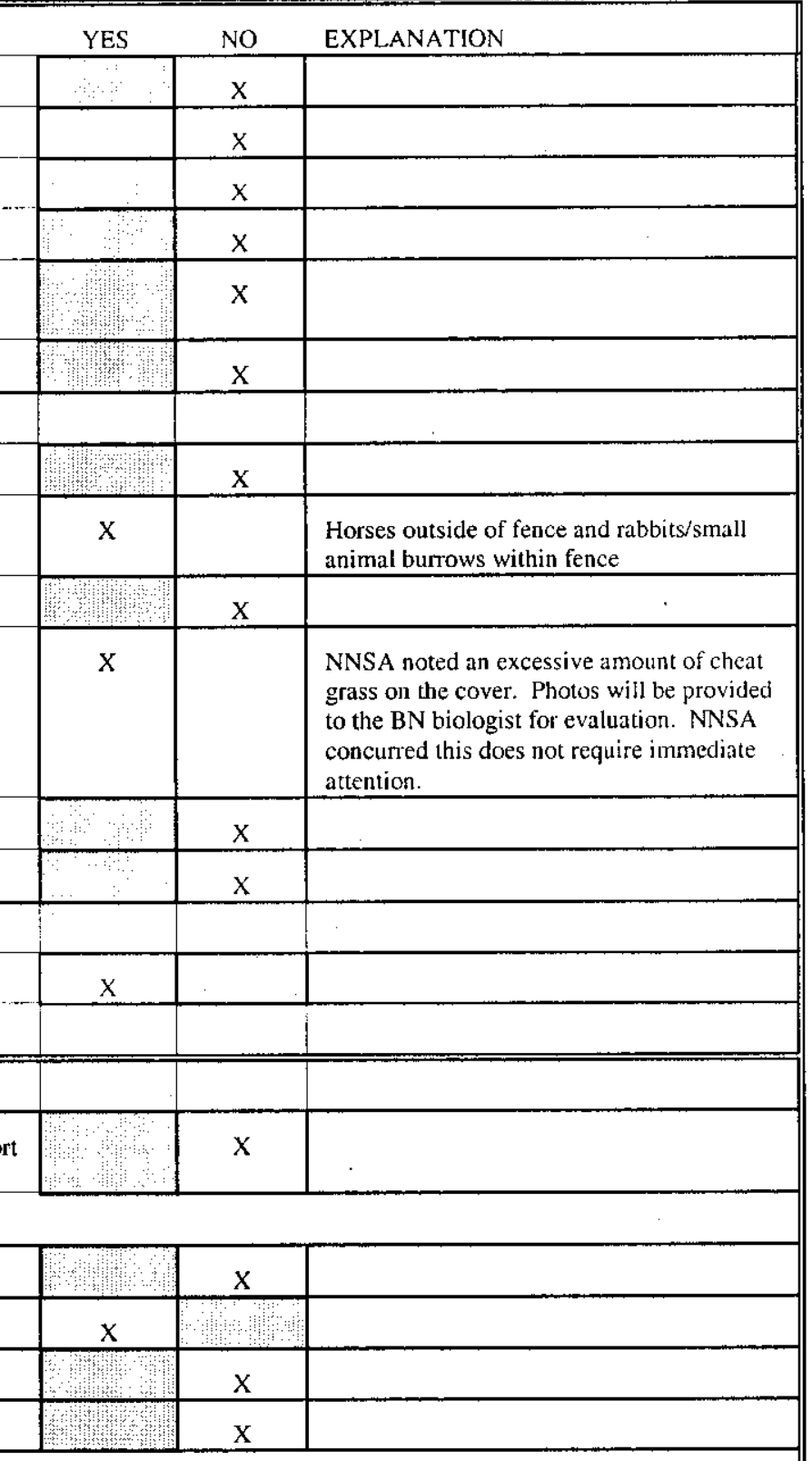

e. Are seeded plant species found on site?

f. Is there evidence of plant mortality?

5. Photo Documentation

a. Has a photo log been prepared?

b. Number of photos exposed (8)

\section{FIELD CONCLUSIONS}

1. Is there an imminent hazard to the integrity of the unit? (Immediate report required)

Person/Agency to whom report made:

2. Are more frequent inspections required?

3. Are existing maintenance/repair actions satisfactory?

4. Is other maintenance/repair necessary?

5. Is current status/condition of vegetative cover satisfactory?

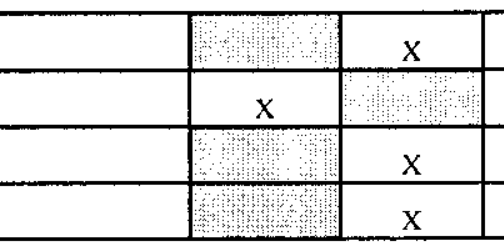

6. Rationale for field conclusions: The site is generally in good condition. No erosion or damage was.noted other than a section of wire down on the fence near the gate. Minor repairs were made at the time of the inspection. The wire and sign will be more securely attached at the same time repairs are made at other $\mathrm{PCI}$ sites. In addition to the repairs, a response is due to NNSA within 90 days on why no use restriction signs are present at the site. If possible, the NNSA TM requested UR signs to be installed per the FFACO handbook. A follow up inspection will be completed at the completion of repair activities and observations will be documented.

\section{E. CERTIFICATION}

I have conducted an inspection of the Roller Coaster RadSafe Area, CAU 407, at the TTR in accordance with the Post-C.losure Monitoring l'an (sec Closure Report) as recorded on this checklist, attached sheets, field notes, photo logs, and photographs.

Chief Inspector's Signature:

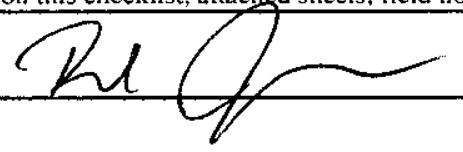

Printed Name: Brad Jackson

Title: TTR PCI Task Manger

Date: 15 November 2005 
CAU 423: AREA 3 UNDERGROUND DISCHARGE POINT, POST-CLOSURE INSPECTION CHECKLIST

Inspection Date: 15 November 2005

Responsible Agency: NNSANSO ER

NNSA Project Manager: Kevin Cabble

Date of Last Inspection: 02 June 2005

Reason for Last Inspection: Semiannual inspection

Inspector (name, title, organization): Brad Jackson BNER

Assistant Inspector (name, title, organization): N/A

\section{A. GENERAL INSTRUCTIONS}

1. All checklist items must be completed and detailed comments made to document the results of the site inspection. The completed checklist is part of the field record of the inspection. Additional pages should be used as necessary to ensure that a complete record is provided. Attach the additional pages and number all pages upon completion of the inspection.

2. Any checklist line item marked by an inspector in a SHADED BOX, must be fully explained or an appropriate reference to previous reports provided. The purpose of this requirement is to provide a written explanation of inspector observations and the inspector's rationale for conclusions and recommendations. Explanations are to be placed on additional attachments and cross-referenced appropriately.

Explanations, in addition to narrative, will take the form of sketches, measurements, and annotated site maps.

3. The site inspection is a walking inspection of the entire site including the perimeter and sufficient transects to be able to examine the entire surface and all features specifically described in the checklist.

4. A standard set of color $35 \mathrm{~mm}$ photographs (or equivalent) is required. In addition, all anomalous features or new features (such as changes in adjacent area land use) are to be photographed. A photo log entry will be made for each photograph taken.

5. This unit will be inspected biannually with formal reporting to the Nevada Division of Environmental Protection to be done annually. The annual report will include an executive summary, this inspection checklist with field notes and photo log attached, and recommendations and conclusions.

\begin{tabular}{|c|c|c|c|}
\hline B. PREPARATION (To be completed prior to site visit) & YES & NO & EXPLANATION \\
\hline 1. Site as-built plans and site base map reviewed. & $\mathrm{x}$ & & \\
\hline 2. Previous inspection reports reviewed. & $\mathbf{X}$ & 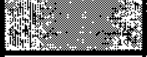 & \\
\hline a. Were anomalies or trends detected on previous inspections? & Hat & $\mathbf{X}$ & \\
\hline b. Was maintenance performed? & W & $\mathrm{x}$ & \\
\hline 3. Site maintenance and repair records reviewed. & 3 & $\mathbf{x}$ & N/A \\
\hline a. Has site repair resulted in a change from as-built conditions? & 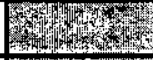 & $\mathbf{X}$ & $\mathrm{N} / \mathrm{A}$ \\
\hline b. Are revised as-builts available that reflect repair changes? & r & $\mathrm{X}$ & $\mathrm{N} / \mathrm{A}$ \\
\hline C. SITE INSPECTION (To be completed during inspection) & YES & NO & EXPLANATION \\
\hline \multicolumn{4}{|l|}{ 1. Adjacent off-site features within watershed areas. } \\
\hline a. Have there been any changes in use of adjacent area? & $\mathrm{x}$ & 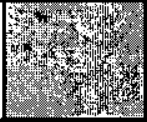 & $\begin{array}{l}\text { Underground water line installation is } \\
\text { ongoing in the area. The site was not } \\
\text { disturbed as of this inspection. }\end{array}$ \\
\hline b. Are there any new roads or trails? & - & $\mathrm{X}$ & \\
\hline c. Has there been a change in the position of nearby washes? & $\mathrm{X}$ & 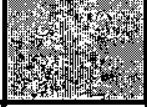 & $\begin{array}{l}\text { Underground water line installation is } \\
\text { ongoing in the area. The site was not } \\
\text { disturbed as of this inspection. }\end{array}$ \\
\hline $\begin{array}{l}\text { d. Has there been lateral excursion or erosion/deposition of nearby } \\
\text { washes? }\end{array}$ & $=0$ & $\mathrm{X}$ & \\
\hline e. Are there new drainage channels? & 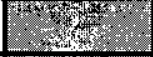 & $\mathrm{X}$ & \\
\hline f. Change in surrounding vegetation? & (4) & $\mathrm{X}$ & \\
\hline \multicolumn{4}{|l|}{ 2. Security fence, signs. } \\
\hline a. Displacement of site markers, boundary markers, or monuments? & 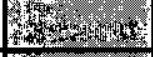 & $\mathrm{X}$ & \\
\hline $\begin{array}{l}\text { b. Have any signs been damaged or } \text { f }^{\text {moved? }} \\
\text { (Number of signs replaced: }\end{array}$ & 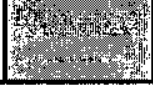 & $\mathrm{X}$ & \\
\hline
\end{tabular}




\section{CAU 423: AREA 3 UNDERGROUND DISCHARGE POINT, POST-CLOSURE INSPECTION CHECKLIST}

\begin{tabular}{|c|c|c|c|}
\hline 3. Use Restricted Area: & YES & NO & EXPLANATION \\
\hline a. Is there evidence of settling? & & $\mathrm{X}$ & \\
\hline b. Is there cracking? & & $\mathrm{X}$ & \\
\hline c. Is there evidence of erosion (wind or water)? & & $\mathrm{X}$ & \\
\hline d. Is there evidence of animal burrowing? & & \\
\hline e. Have the site markers been disturbed by man or natural processes? & & $\mathrm{X}$ & \\
\hline f. Is there vegetation in the area? & & $\mathrm{X}$ & \\
\hline g. Do natural processes threaten to integrity of any cover or site & & $\mathrm{X}$ & \\
\hline h. Other? & & $\mathrm{X}$ & \\
\hline
\end{tabular}

4. Photo Documentation

a. Has a photo log been prepared?

$\mathrm{X}$

b. Number of photos exposed (2)

\section{FIELD CONCLUSIONS}

1. Is there an imminent hazard to the integrity of the unit? (Immediate report required)

Person/Agency to whom report made:

2. Are more frequent inspections tequired?

3. Are existing maintenance/repair actions satisfactory?

4. Is other maintenance/repair necessary?

5. Is current status/condition of the site satisfactory?

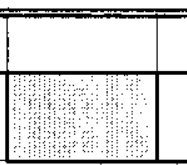

\begin{tabular}{|l|l}
\hline & \\
\hline
\end{tabular}

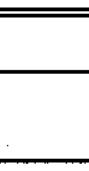

6. Rationale for field conclusions: Site is in good condition and all excavations were will away from the use restricted area. Discussed upcoming fieldwork to remove piping with NNSA and BN personnel.

\section{E. CERTIFICATION}

I have conducted an inspection of the Area 3 Underground Discharge Point. CAU 423, at the TTR in accordance with the Post-Closure Inspection Plan (see Closure Report) as recorded on this checklist, attached sheets, field notes, photo logs, and photographs.

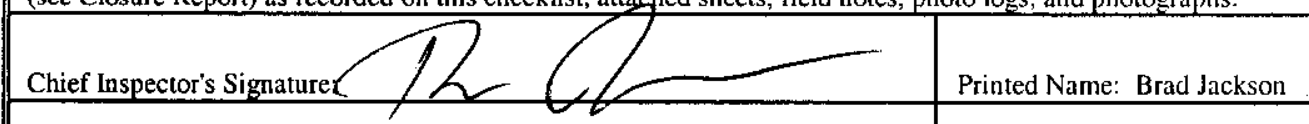

Title: TTR PCI Task Manager

Date: 15 November 2005 


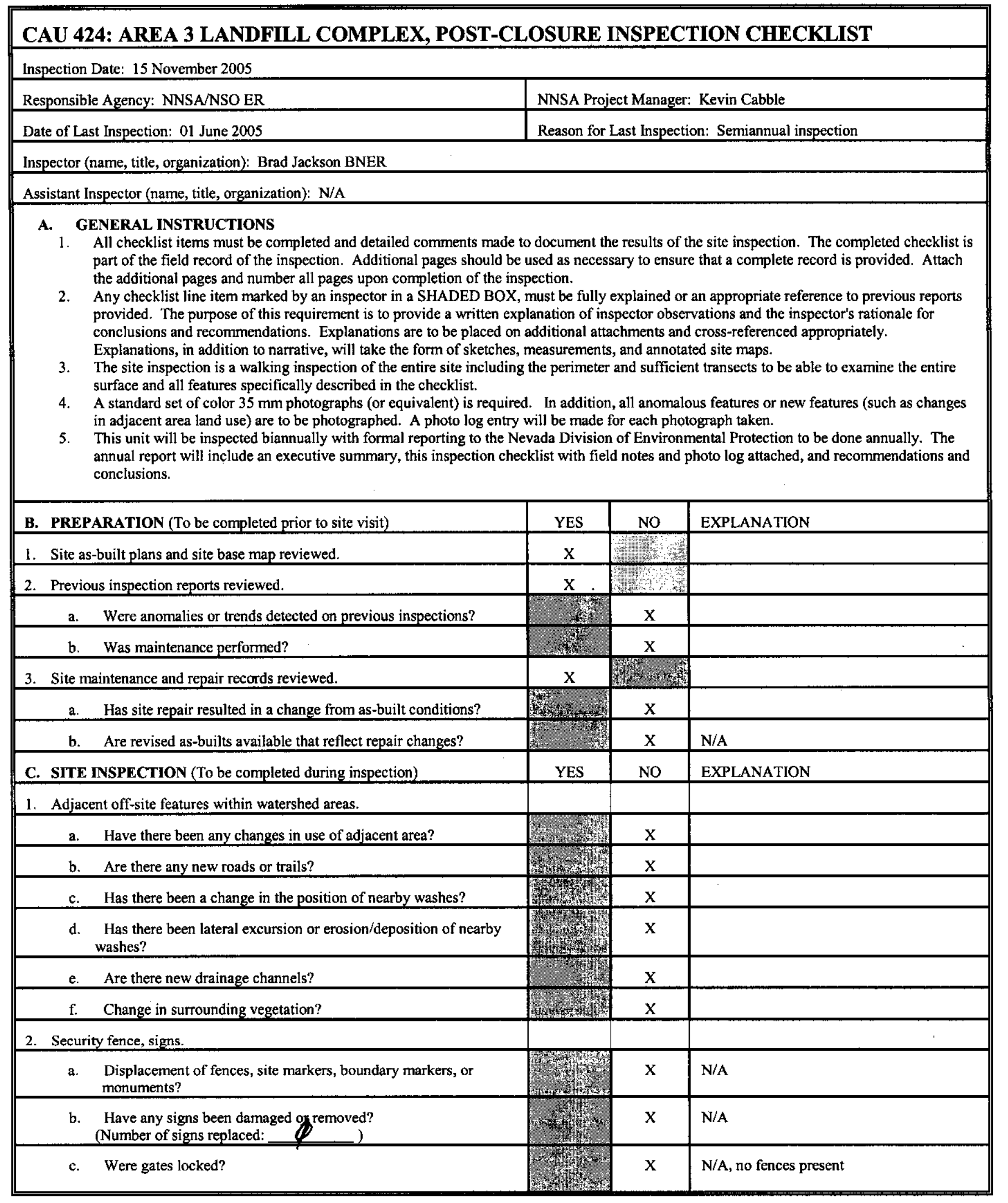




\section{CAU 424: AREA 3 LANDFILL COMPLEX, POST-CLOSURE INSPECTION CHECKLIST}

3. Waste Unit cover.

a. Is there evidence of settling?

b. Is there cracking?

c. Is there evidence of erosion around the cap (wind or water)?

d. Is there evidence of animal burtowing?

e. Have the site markers been disturbed by man or natura! processes?

f. Is the vegetation on the cover?

g. Do natural processes threaten to integrity of any cover or site marker?

h. Other?

4. Photo Documentation

a. Has a photo $\log$ been prepared?

b. Number of photos exposed (21)

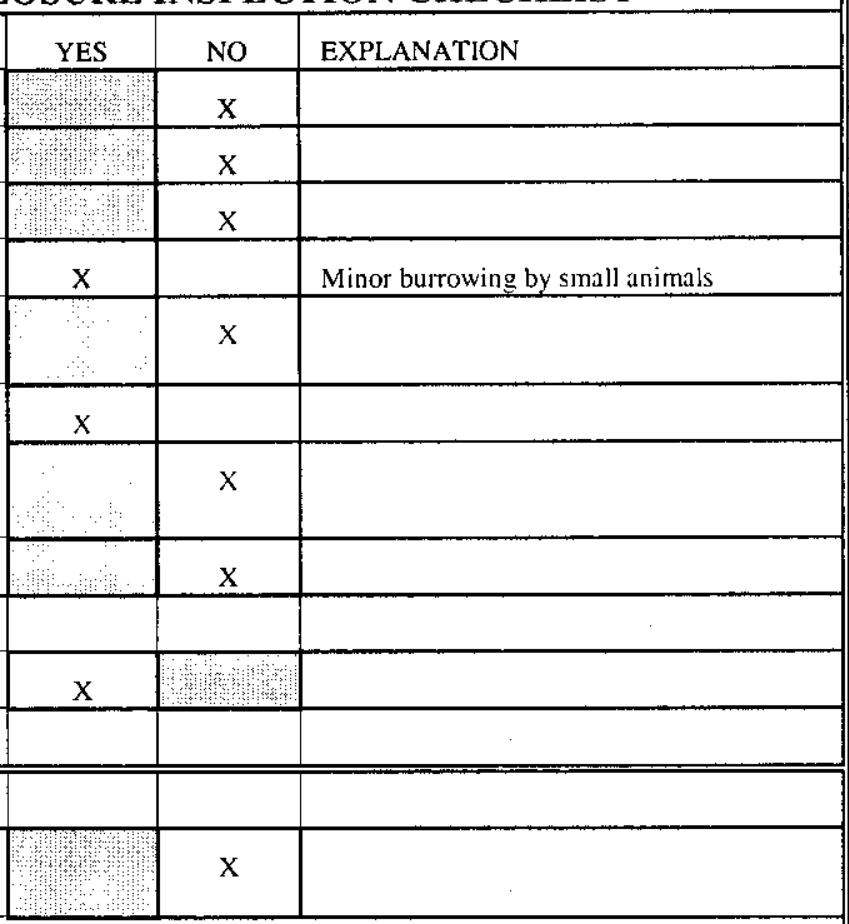

D. FIELD CONCLUSIONS

1. Is there an imminent hazard to the integrity of the unit? (Immediate report required)

Person/Agency to whom report made:

2. Are more frequent inspections required?

3. Are existing maintenance/repair actions satisfactory?

4. Is other maintenance/repair necessary?

5. Is current status/condition of vegetative cover satisfactory?

\begin{tabular}{|c|c|}
\hline 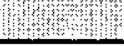 & $x$ \\
\hline$x$ & \\
\hline \% & $x$ \\
\hline$x$ & \\
\hline
\end{tabular}

6. Rationale for field conclusions: The site is in good condition. Some small animal burtows were noted during the inspection

\section{E. CERTIFICATION}

I have conducted an inspection of the Area 3 Landfill Complex, CAU 424, at the TTR in accordance with the Post-Closure Inspection Plan (see Closure Report) as recorded on this checklist, attached sheets, field notes, photo logs, and photographs.

Chief Inspector's Signature:

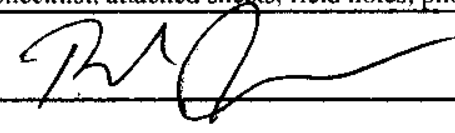

Title: TTR PCI Task Manager

Printed Name: Brad Jackson

Date: 15 November 2005 
CAU 426: CACTUS SPRING WASTE TRENCHES, POST-CLOSURE INSPECTION CHECKLIST

Inspection Date: 15 November 2005

Responsible Agency: NNSA/NSO ER

NNSA Project Manager: Kevin Cabble

Date of Last Inspection: 02 June 2005

Reason for Last Inspection: Semiannual inspection

Inspector (name, title, organization): Brad Jackson BNER

Assistant Inspector (name, title, organization): N/A

\section{A. GENERAL INSTRUCTIONS}

1. All checklist items must be completed and detailed comments made to document the results of the site inspection. The completed checklist is part of the field record of the inspection. Additional pages should be used as necessary to ensure that a complete record is provided. Attach the additional pages and number all pages upon completion of the inspection.

2. Any checklist line item marked by an inspector in a SHADED BOX, must be fully explained or an appropriate reference to previous reports provided. The purpose of this requirement is to provide a written explanation of inspector observations and the inspector's rationale for conclusions and recommendations. Explanations are to be placed on additional attachments and cross-referenced appropriately.

Explanations, in addition to narrative, will take the form of sketches, measurements, and annotated site maps.

3. The site inspection is a walking inspection of the entire site including the perimeter and sufficient transects to be able to examine the entire surface and all features specifically described in the checklist.

4. A standard set of color $35 \mathrm{~mm}$ photographs (or equivalent) is required. In addition, all anomalous features or new features (such as changes in adjacent area land use) are to be photographed. A photo log entry will be made for each photograph taken.

5. This unit will be inspected biannually with formal reporting to the Nevada Division of Environmental Protection to be done annually. The annual report will include an executive summary, this inspection checklist with field notes and photo log attached, and recommendations and conclusions.

\begin{tabular}{|c|c|c|c|}
\hline B. PREPARATION (To be completed prior to site visit) & YES & NO & EXPLANATION \\
\hline 1. Site as-built plans and site base map reviewed. & $\mathrm{X}$ & - & \\
\hline 2. Previous inspection reports reviewed. & $\mathrm{x}$ & 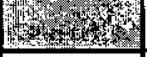 & \\
\hline a. Were anomalies or trends detected on previous inspections? & 3. & $\mathrm{X}$ & \\
\hline b. Was maintenance performed? & & $\mathrm{X}$ & \\
\hline 3. Site maintenance and repair records reviewed. & $\mathrm{X}$ & 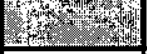 & \\
\hline a. Has site repair resulted in a change from as-built conditions? & & $\mathrm{X}$ & \\
\hline b. Are revised as-builts available that reflect repair changes? & & $\mathrm{x}$ & N/A \\
\hline C. SITE INSPECTION (To be completed during inspection) & YES & No & EXPLANATION \\
\hline \multicolumn{4}{|l|}{ 1. Adjacent off-site features within watershed areas. } \\
\hline a. Have there been any changes in use of adjacent area? & & $\mathrm{x}$ & \\
\hline b. Are there any new roads or trails? & 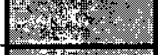 & $\underline{X}$ & \\
\hline c. Has there been a change in the position of nearby washes? & & $\mathrm{X}$ & \\
\hline $\begin{array}{l}\text { d. Has there been lateral excursion or erosion/deposition of nearby } \\
\text { washes? }\end{array}$ & 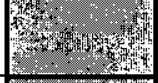 & $\mathrm{X}$ & \\
\hline e. Are there new drainage channels? & P- & $\mathrm{X}$ & \\
\hline f. Change in surrounding vegetation? & (4) & $\mathrm{X}$ & \\
\hline \multicolumn{4}{|l|}{ 2. Security fence, signs. } \\
\hline $\begin{array}{l}\text { a. Displacement of fences, site markers, boundary markers, or } \\
\text { monuments? }\end{array}$ & 20 & $\mathrm{X}$ & \\
\hline $\begin{array}{l}\text { b. Have any signs been damaged ogremoved? } \\
\text { (Number of signs replaced: }\end{array}$ & 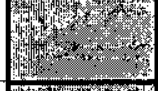 & $\mathrm{x}$ & \\
\hline c. Were gates locked? & - & $\mathrm{X}$ & N/A \\
\hline
\end{tabular}




\section{CAU 426: CACTUS SPRING WASTE TRENCHES, POST-CLOSURE INSPECTION CHECKLIST}

3. Waste Unit cover.

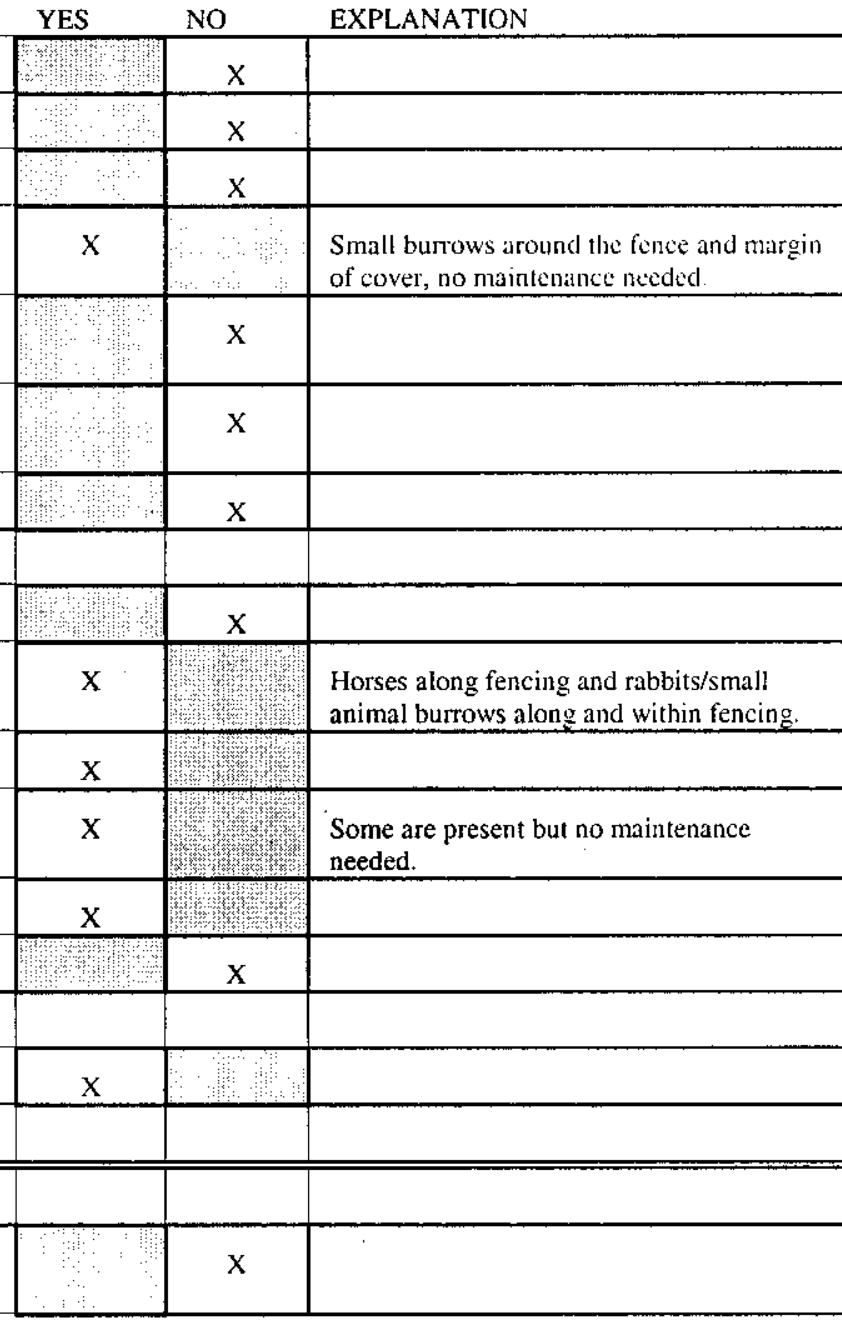

a. Is there evidence of settling?

b. Is there cracking?

c. Is there evidence of erosion around the cap (wind or water)?

d. Is there evidence of animal burrowing?

e. Have the site markers been disturbed by man or natural processes?

f. Do natural processes threaten to integrity of any cover or site marker?

g. Other?

4. Vegetative cover.

a. Is perimeter fence or mesh fencing damaged?

b. Is there evidence of horses or rabbits on site?

c. Is organic mulch and/or plants adequate to prevent erosion?

d. Are weedy annual plants present? If yes, are they a problem?

e. Are seeded plant species found on site?

f. Is there evidence of plant mortality?

5. Photo Documentation

a. Has a photo $\log$ been prepared?

b. Number of photos exposed (7)

1. Is there an imminent hazard to the integrity of the unit? (Immediate report required)

Person/Agency to whom report made:

2. Are more frequent inspections required?

3. Are existing maintenance/repair actions satisfactory?

4. Is other maintenance/repair necessary?

5. Is current status/condition of vegetative cover satisfactory?

\begin{tabular}{|c|c|}
\hline 8 & $\mathrm{X}$ \\
\hline $\mathrm{X}$ & \\
\hline $1 \cdots$ & $x$ \\
\hline Ka & $X$ \\
\hline
\end{tabular}

6. Rationale for field conclusions: The site is in good condition and there was no damage to the fencing or cover noted during the inspection. Some small animal burrows were noted during the inspection but no maintenance/repairs are needed.

\section{E. CERTIFICATION}

I have conducted an inspection of the Cactus Spring Waste Trenches, CAU 426, at the TTR in accordance with the Post-Closure Monitoring Plan (sec Closure Report) as recorded on this checklist, attached sheets, field notes, photo logs, and photographs.

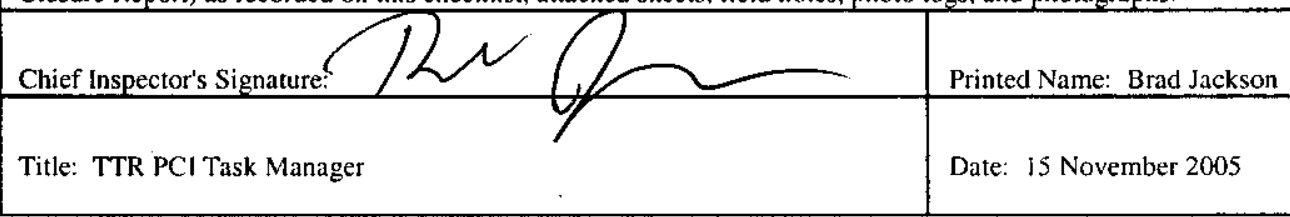


CAU 427: AREA 3 SEPTIC WASTE SYSTEMS 2 \& 6, POST-CLOSURE INSPECTION CHECKLIST

Inspection Date: 16 November 2005

Responsible Agency: NNSA/NSO ER

NNSA Project Manager: Kevin Cabble

Date of Last Inspection: 02 June 2005

Reason for Last Inspection: Semiannual inspection

Inspector (name, title, organization): Brad Jackson BNER

Assistant Inspector (name, title, organization): N/A

\section{A. GENERAL INSTRUCTIONS}

1. All checklist items must be completed and detailed comments made to document the results of the site inspection. The completed checklist is part of the field record of the inspection. Additional pages should be used as necessary to ensure that a complete record is provided. Attach the additional pages and number all pages upon completion of the inspection.

2. Any checklist line item marked by an inspector in a SHADED BOX, must be fully explained or an appropriate reference to previous reports provided. The purpose of this requirement is to provide a written explanation of inspector observations and the inspector's rationale for conclusions and recommendations. Explanations are to be placed on additional attachments and cross-referenced appropriately. Explanations, in addition to narrative, will take the form of sketches, measurements, and annotated site maps.

3. The site inspection is a walking inspection of the entire site including the perimeter and sufficient transects to be able to examine the entire surface and all features specifically described in the checklist.

4. A standard set of color $35 \mathrm{~mm}$ photographs (or equivalent) is required. In addition, all anomalous features or new features (such as changes in adjacent area land use) are to be photographed. A photo log entry will be made for each photograph taken.

5. This unit will be inspected biannually with formal reporting to the Nevada Division of Environmental Protection to be done annually. The annual report will include an executive summary, this inspection checklist with field notes and photo log attached, and recommendations and conclusions.

\begin{tabular}{|c|c|c|c|}
\hline B. PREPARATION (To be completed prior to site visit) & YES & No & EXPLANATION \\
\hline 1. Site as-built plans and site base map reviewed. & $\mathrm{X}$ & $y=-4$ & \\
\hline 2. Previous inspection reports reviewed. & $\mathrm{X}$ & P. & \\
\hline a. Were anomalies or trends detected on previous inspections? & 4 & $\mathrm{X}$ & \\
\hline b. Was maintenance performed? & 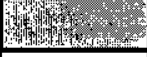 & $\mathrm{X}$ & \\
\hline 3. Site maintenance and repair records reviewed. & $\mathrm{X}$ & 6 & \\
\hline a. Has site repair resulted in a change from as-built conditions? & 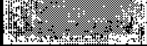 & $\mathrm{x}$ & \\
\hline b. Are revised as-builts available that reflect repair changes? & Hent & $\mathbf{X}$ & $\mathrm{N} / \mathrm{A}$ \\
\hline C. SITE INSPECTION (To be completed during inspection) & YES & No & EXPLANATION \\
\hline \multicolumn{4}{|l|}{ 1. Adjacent off-site features within watershed areas. } \\
\hline a. Have there been any changes in use of adjacent area? & & $\mathbf{X}$ & \\
\hline b. Are there any new roads or trails? & 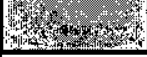 & $\mathbf{X}$ & \\
\hline \multicolumn{4}{|l|}{ 2. Security signs. } \\
\hline $\begin{array}{l}\text { Displacement of site markers, boundary markers, or monuments? } \\
\text { (disturbed by man or natural processes?) }\end{array}$ & $\frac{1}{4}+2$ & $\mathrm{X}$ & $\begin{array}{l}\text { The site was closely inspected and corner } \\
\text { marker locations measured to ensure near by } \\
\text { water line excavation had not encroached on } \\
\text { the UR. At the time of the inspection, the } \\
\text { excavation had not violated the UR. } \\
\text { NNSA requested that at-grade monuments } \\
\text { be installed for better marking of the } \\
\text { leachfields. }\end{array}$ \\
\hline $\begin{array}{l}\text { b. Have any signs been damaged or pemoved? } \\
\text { (Number of signs replaced: }\end{array}$ & 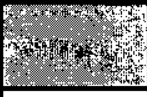 & $\mathbf{X}$ & \\
\hline $\begin{array}{l}\text { c. Were all subsurface markers detected? (i.e., using a magnetometer } \\
\text { or equivalent) }\end{array}$ & $\mathrm{x}$ & $\begin{array}{l}3 \\
3 \\
4\end{array}$ & \\
\hline
\end{tabular}




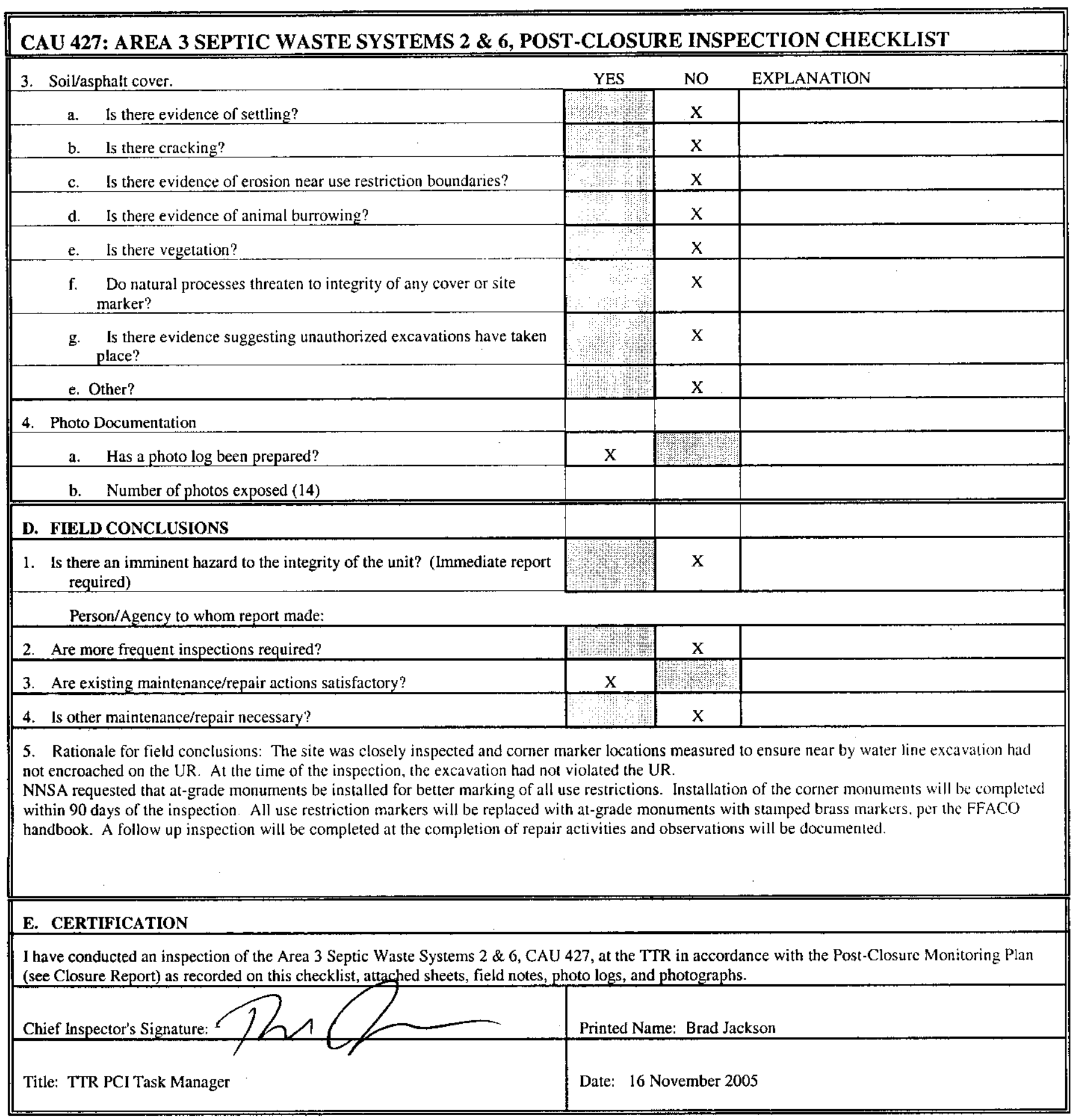


CAU 453: AREA 9 UXO LANDFILL, POST-CLOSURE INSPECTION CHECKLIST

Inspection Date: 16 November 2005

Responsible Agency: NNSA/NSO ER

NNSA Project Manager: Kevin Cabble

Date of Last Inspection: 02 June 2005

Reason for Last Inspection: Semiannual inspection

Inspector (name, title, organization): Brad Jackson BNER

Assistant Inspector (name, title, organization): N/A

A. GENERAL INSTRUCTIONS

1. All checklist items must be completed and detailed comments made to document the results of the site inspection. The completed checklist is part of the field record of the inspection. Additional pages should be used as necessary to ensure that a complete record is provided. Attach the additional pages and number all pages upon completion of the inspection.

2. Any checklist line item marked by an inspector in a SHADED BOX, must be fully explained or an appropriate reference to previous reports provided. The purpose of this requirement is to provide a written explanation of inspector observations and the inspector's rationale for conclusions and recommendations. Explanations are to be placed on additional attachments and cross-referenced appropriately.

Explanations, in addition to narrative, will take the form of sketches, measurements, and annotated site maps.

3. The site inspection is a walking inspection of the entire site including the perimeter and sufficient transects to be able to examine the entire surface and all features specifically described in the checklist.

4. A standard set of color $35 \mathrm{~mm}$ photographs (or equivalent) is required. In addition, all anomalous features or new features (such as changes in adjacent area land use) are to be photographed. A photo log entry will be made for each photograph taken.

5. This unit will be inspected biannually with formal reporting to the Nevada Division of Environmental Protection to be done annually. The annual report will include an executive summary, this inspection checklist with field notes and photo log attached, and recommendations and conclusions.

\begin{tabular}{|c|c|c|c|}
\hline B. PREPARATION (To be completed prior to site visit) & YES & NO & EXPLANATION \\
\hline 1. Site as-built plans and site base map reviewed. & $\mathbf{X}$ & 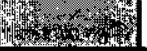 & \\
\hline 2. Previous inspection reports reviewed. & $\mathrm{X}$ & 促 & \\
\hline a. Were anomalies or trends detected on previous inspections? & $\mathrm{X}$ & 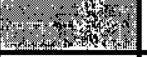 & Subsidence, see below \\
\hline b. Was maintenance performed? & 8; & $\mathrm{X}$ & \\
\hline 3. Site maintenance and repair records reviewed. & $\mathbf{X}$ & 37 & \\
\hline a. Has site repair resulted in a change from as-built conditions? & U.t. & $\mathrm{X}$ & \\
\hline b. Are revised as-builts available that reflect repair changes? & 1960 & $\mathrm{X}$ & $\mathrm{N} / \mathrm{A}$ \\
\hline C. SITE INSPECTION (To be completed during inspection) & YES & No & EXPLANATION \\
\hline \multicolumn{4}{|l|}{ 1. Adjacent off-site features within watershed areas. } \\
\hline a. Have there been any changes in use of adjacent area? & & $\mathrm{X}$ & \\
\hline b. Are there any new roads or trails? & 和 & $\underline{X}$ & \\
\hline c. Has there been a change in the position of nearby washes? & & $\underline{x}$ & \\
\hline $\begin{array}{l}\text { d. Has there been lateral excursion or erosion/deposition of nearby } \\
\text { washes? }\end{array}$ & & $\mathrm{X}$ & \\
\hline e. Are there new drainage channels? & 2010 & $\mathbf{X}$ & \\
\hline f. Change in surrounding vegetation? & (3) & $\mathrm{X}$ & \\
\hline \multicolumn{4}{|l|}{ 2. Security fence, signs. } \\
\hline $\begin{array}{l}\text { a. Displacement of fences, site markers, boundary markers, or } \\
\text { monuments? }\end{array}$ & & $\mathrm{X}$ & \\
\hline $\begin{array}{l}\text { b. Have any signs been damaged or gmoved? } \\
\text { (Number of signs replaced: }\end{array}$ & 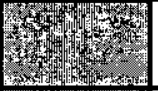 & $\mathrm{X}$ & \\
\hline c. Were gates locked? & 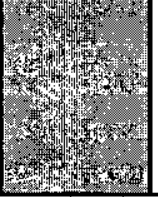 & $\mathrm{X}$ & $\begin{array}{l}\text { No lock present at the time of the } \\
\text { inspection. The previously installed lock } \\
\text { has been removed. } \\
\text { A lock will be installed within } 90 \text { days per } \\
\text { NNSA direction. }\end{array}$ \\
\hline
\end{tabular}




\section{CAU 453: AREA 9 UXO LANDFILL, POST-CLOSURE INSPECTION CHECKLIST}

3. Waste Unit cover.

\begin{tabular}{|c|c|c|}
\hline YES & NO & EXPLANATION \\
\hline $\mathrm{x}$ & & Subsidence, see below \\
\hline \multirow[t]{4}{*}{$x$} & ב & Subsidence, see below \\
\hline & $\mathrm{x}$ & \\
\hline & $\mathrm{x}$ & \\
\hline & $\mathrm{x}$ & \\
\hline \multirow[t]{3}{*}{$x$} & $\therefore$ & Sparse \\
\hline & $x$ & \\
\hline & $x$ & \\
\hline & & \\
\hline \multicolumn{3}{|c|}{$x$} \\
\hline & & \\
\hline & & \\
\hline & $\mathrm{x}$ & \\
\hline
\end{tabular}

a. Is there evidence of settling?

b. Is there cracking?

c. Is there evidence of erosion around the cap (wind or water)?

d. Is there evidence of animal burrowing?

e. Have the site markers been disturbed by man or natural processes?

f. Is vegetation present?

g. Do natural processes threaten to integrity of any cover or site marker?

h. Other'?

4. Photo Documentation

a. Has a photo $\log$ been prepared?

b. Number of photos exposed (7)

\section{FIELD CONCLUSIONS}

1. Is there an imminent hazard to the integrity of the unit? (Immediate report required)

Person/Agency to whom report made:

2. Are more frequent inspections required?

3. Are existing maintenance/repair actions satisfactory?

4. Is other maintenance/repair necessary?

5. Is current status/condition of vegetative cover satisfactory?

6. Rationale for field conclusions: Several large areas of subsidence were noted on cell A9-3, and one small but deep area of subsidence was noted on cell A9-1. Areas of subsidence on cells A9-1 and A9-3 were reviewed with NNSA and BN personnel. Some cracking associated with the subsidence was also noted. The subsidence will be repaired within 90 days of this inspection. A new lock will also be requested from TTR security and installed within 90 days. A follow up inspection will be completed at the completion of repair activities and observations will be documented.

\section{E. CERTIFICATION}

I have conducted an inspection of the Area 9 UXO Landfill, CAU 453, at the TTR in accordance with the Post-Closure Inspection Plan (see Closure Report) as recorded on this checklist, attached sheets, field notes, photo logs, and photographs.

Chief Inspector's Signature:

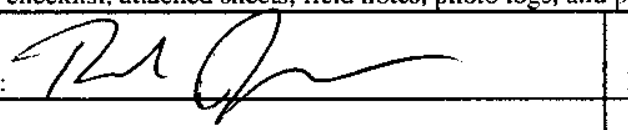

Printed Name: Brad Jackson

Title: TTR PCI Task Manager

Date: 16 November 2005 


\section{CAU 487: THUNDERWELL SITE, POST-CLOSURE INSPECTION CHECKLIST}

\begin{tabular}{|l|l}
\hline Inspection Date: 16 November 2005 & \\
\hline Responsible Agency: NNSA/NSO ER & NNSA Project Manager: Kevin Cabble \\
\hline Date of Last Inspection: 02 June 2005 & Reason for Last Inspection: Semiannual inspection \\
\hline
\end{tabular}

Inspector (name, title, organization): Brad Jackson BNER

Assistant Inspector (name, title, organization): N/A

\section{A. GENERAL INSTRUCTIONS}

1. All checklist items must be completed and detailed comments made to document the results of the site inspection. The completed checklist is part of the field record of the inspection. Additional pages should be used as necessary to ensure that a complete record is provided. Attach the additional pages and number all pages upon completion of the inspection.

2. Any checklist line item marked by an inspector in a SHADED BOX, must be fully explained or an appropriate reference to previous reports provided. The purpose of this requirement is to provide a written explanation of inspector observations and the inspector's rationale for conclusions and recommendations. Explanations are to be placed on additional attachments and cross-referenced appropriately. Explanations, in addition to narrative, will take the form of sketches, measurements, and annotated site maps.

3. The site inspection is a walking inspection of the entire site including the perimeter and sufficient transects to be able to examine the entire surface and all features specifically described in the checklist.

4. A standard set of color $35 \mathrm{~mm}$ photographs (or equivalent) is required. In addition, all anomalous features or new features (such as changes in adjacent area land use) are to be photographed. A photo log entry will be made for each photograph taken.

5. This unit will be inspected biannually with formal reporting to the Nevada Division of Environmental Protection to be done annually. The annual report will include an executive summary, this inspection checklist with field notes and photo log attached, and recommendations and conclusions.

\begin{tabular}{|c|c|c|c|}
\hline B. PREPARATION (To be completed prior to site visit) & YES & NO & EXPLANATION \\
\hline 1. Site as-built plans and site base map reviewed. & $\mathrm{x}$ & - & Closure figures \\
\hline 2. Previous inspection reports reviewed. & $\mathrm{X}$ & 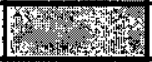 & \\
\hline a. Were anomalies or trends detected on previous inspections? & $\mathrm{X}$ & 17r & Several monuments pushed over by horses \\
\hline b. Was maintenance performed? & $4 x^{2}+2$ & $\mathrm{X}$ & \\
\hline 3. Site maintenance and repair records reviewed. & $\mathrm{x}$ & 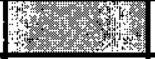 & \\
\hline a. Has site repair resulted in a change from as-built conditions? & $4+x$ & $\mathbf{x}$ & \\
\hline b. Are revised as-builts available that reflect repair changes? & & $\mathrm{X}$ & $\mathrm{N} / \mathrm{A}$ \\
\hline C. SITE INSPECTION (To be completed during inspection) & YES & No & EXPLANATION \\
\hline \multicolumn{4}{|l|}{ 1. Adjacent off-site features within watershed areas. } \\
\hline a. Have there been any changes in use of adjacent area? & & $\underline{x}$ & \\
\hline b. Are there any new roads or trails? & 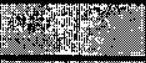 & $\mathrm{X}$ & \\
\hline c. Has there been a change in the position of nearby washes? & 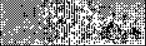 & $\mathrm{X}$ & \\
\hline $\begin{array}{l}\text { d. Has there been lateral excursion or erosion/deposition of nearby } \\
\text { washes? }\end{array}$ & 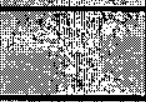 & $\mathrm{x}$ & \\
\hline e. Are there new drainage channels? & 25. & $\underline{x}$ & \\
\hline f. Change in surrounding vegetation? & 2 & $\mathrm{x}$ & \\
\hline \multicolumn{4}{|l|}{ 2. Security fence, signs. } \\
\hline $\begin{array}{l}\text { a. Displacement of fences, site markers, boundary markers, or } \\
\text { monuments? }\end{array}$ & $\mathrm{x}$ & 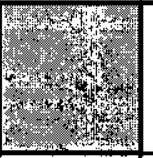 & $\begin{array}{l}\text { Several monuments pushed over by horses, } \\
\text { and two monuments have cracked or broken } \\
\text { tops. Monuments will be repaired within } 90 \\
\text { days. }\end{array}$ \\
\hline 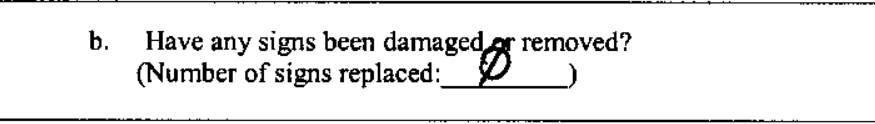 & Wot & $\mathbf{x}$ & \\
\hline
\end{tabular}




\section{CAU 487: THUNDERWELL SITE, POST-CLOSURE INSPECTION CHECKLIST}

\begin{tabular}{|c|c|c|c|}
\hline 3. Waste Unit cover. & YES & No & EXPLANATION \\
\hline a. Is there evidence of settling? & Why & $\mathrm{X}$ & \\
\hline b. Is there evidence of animal burrowing? & $\mathbf{X}$ & 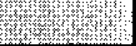 & Minor \\
\hline $\begin{array}{l}\text { c. Have the site markers been disturbed by man or natural } \\
\text { processes? }\end{array}$ & $\mathbf{x}$ & Wh: & $\begin{array}{l}\text { Several monuments pushed over by horses, } \\
\text { and two monuments have cracked or broken } \\
\text { tops. Monuments will be repaired within } 90 \\
\text { days. }\end{array}$ \\
\hline d. Other? & 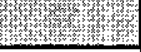 & $\mathrm{X}$ & \\
\hline \multicolumn{4}{|l|}{ 4. Photo Documentation } \\
\hline a. Has a photo log been prepared? & $\mathrm{x}$ & Wh: & \\
\hline \multicolumn{4}{|l|}{ b. Number of photos exposed (6) } \\
\hline \multicolumn{4}{|l|}{ D. FIELD CONCLUSIONS } \\
\hline $\begin{array}{l}\text { 1. Is there an imminent hazard to the integrity of the unit? (Immediate report } \\
\text { required) }\end{array}$ & & $\mathrm{x}$ & \\
\hline \multicolumn{4}{|l|}{ Person/Agency to whom report made: } \\
\hline 2. Are more frequent inspections required? & & $\mathrm{X}$ & \\
\hline 3. Are existing maintenance/repair actions satisfactory? & $\mathrm{X}$ & 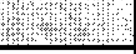 & \\
\hline 4. Is other maintenance/repair necessary? & Whoty & $x$ & \\
\hline 5. Is current status/condition of vegetative cover satisfactory? & $\mathrm{x}$ & 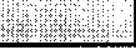 & \\
\hline \multicolumn{4}{|c|}{$\begin{array}{l}\text { 6. Rationale for field conclusions: Several monuments have been pushed over by horses. Two of the monument tops were cracked and/or broken, the } \\
\text { monuments will be repaired using an appropriate concrete repairing material (glue, epoxy, or cement-based mixture). Repairs will be made within } \\
90 \text { days. Monuments will be either placed deeper, set with a footing, or have posts set around them to better protect from vandal horses. A follow } \\
\text { up inspection will be completed at the completion of repair activities and observations will be documented. }\end{array}$} \\
\hline \multicolumn{4}{|l|}{ E. CERTIFICATION } \\
\hline \multicolumn{4}{|c|}{$\begin{array}{l}\text { I have conducted an inspection of the Area } 9 \text { UXO Landfill, CAU 453, at the TTR in accordance with the Post-Closure Inspection Ptan (see Closure } \\
\text { Report) as recorded on this checklist, attached sheets, field notes, photo logs, and photographs. }\end{array}$} \\
\hline Chief Inspector's Signature: & \multicolumn{3}{|c|}{ Printed Name: Brad Jackson } \\
\hline Title: TTR PCI Task Manager & \multicolumn{3}{|c|}{ Date: 16 November 2005} \\
\hline
\end{tabular}


Post-Closure Inspection Report - TTR

Revision: 0

Date: June 2006

\section{ATTACHMENT D.}

\section{FIELD NOTES}


Post-Closure Inspection Report - TTR

Revision: 0

Date: June 2006

\section{THIS PAGE INTENTIONALLY LEFT BLANK}


176 PROJECT NO.

BOOK NO.

Wed April 6, 2005
TITLE CAL 427 LUR boundary marking Work continued from Page $N / A$

CAl 427: Area 3 septic waste systems 266 , TR CAS 03-05-002-sw02

LAs 03-05-002-5w06

Persmand: $T L$ Shaughn Burnison

Tor Brad Jackson

Nasa Rep kevin Cable

waS Laver Ben Sperry

WGS Labour Atlas?

WGS Laborer Jodi kanstmon

Equipment: Shovels, pick, wheelbarrow $6 \mathrm{cu}$. ft red cinder rock. $2 \times 100^{\prime}$ Tapemeasures, Englaeiering site schematic, Measurement Dagrains from FYO3 PCIR

Weather: Warm a windy $\left(65^{\circ}\right)$; wind 20 mph South

Scope: Locate dig out comer points of 5 use restricted areas

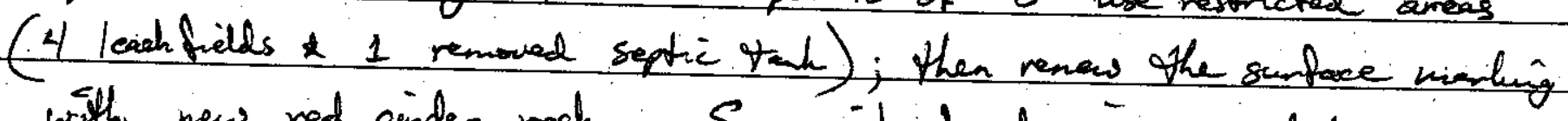
with new red cinder rock. Sorry paint boundaries as needed.

20

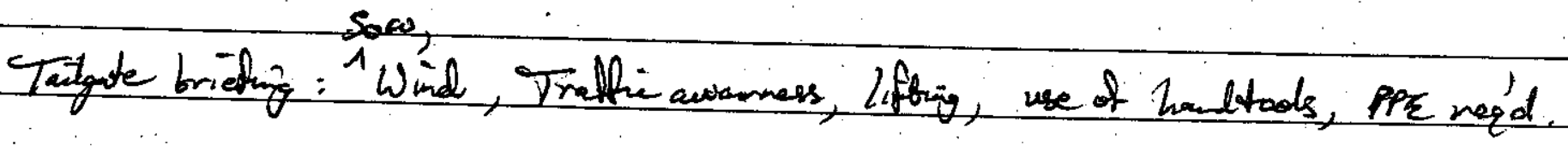

2:00 pm: Converged to ste, explained sow to cow, safety brief; Located 13 of 21 markers $x$ dy out old material t surface ind ll. Marcel boundaries of over lopping Terichifields "A, "B", \& "Abachood" with paint. Mashed of

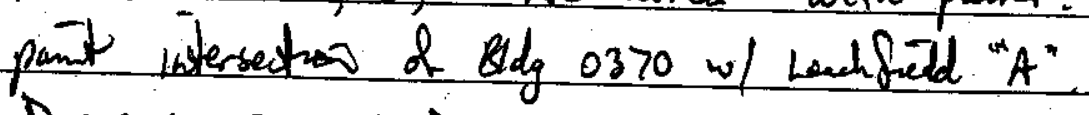

Departed tor the DaY....

Work continued to Page 177

SIGNATURE

Disclosed TO AND UNDERSTOOD BY

DATE

WINES

Dart $4 / 6 / 05$ 
TITLE

Work continued from Page 176

Thu April 7, 2005 CAM 422 costunide...

PROJECT NO. CAL 427

BOOK NO.

177

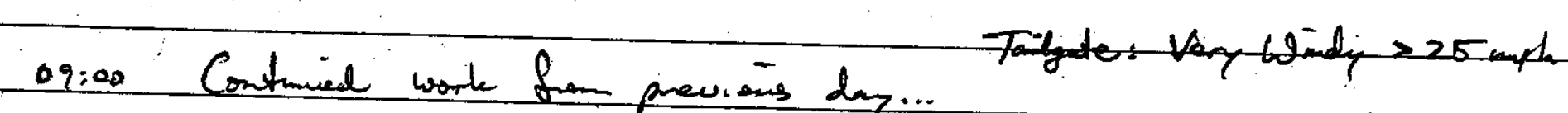
Located remaining 8 corner point, inch ling Pom "Be -65 " leachifild \& 5 points form removed septic tank $33-5$.

Renewed red cinder -rack making internal in each dugout hole.

10:30 Tob complete

10

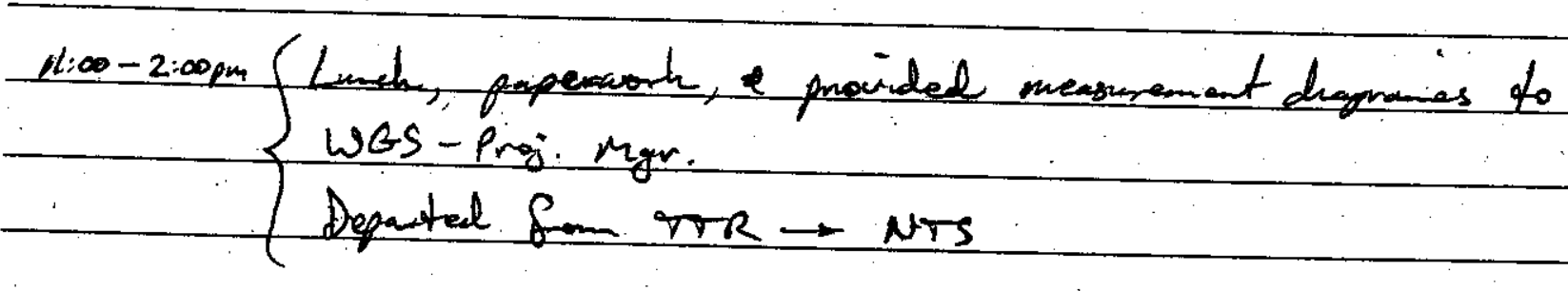

15
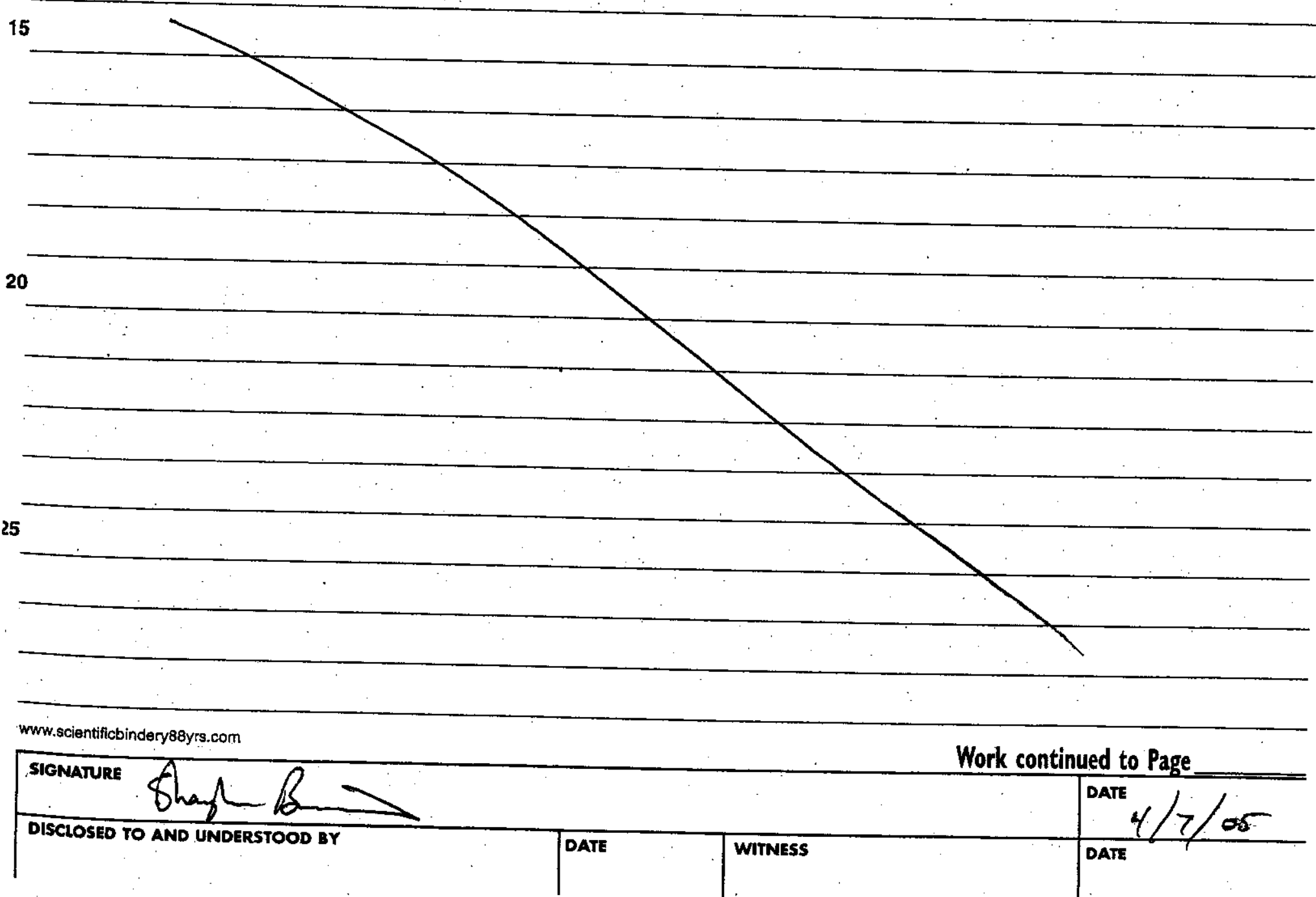
110 TITLE

Work continued from Page
PROJECT NO.

BOOK NO.

1 Jure 05

ITR Post-Close Irspeotious

weathen clear, warm, wh list wird

B. Janksor \& K. Cabble

1127 - CAV 424 LF 3-2 Photos $97,96,895$

5 Monuments are ir sood coddition and all sises are readable verectortio is rell estublisler. No issues notes.

1142 - CAU 424 LF 3-1 Photos $94,93 \% 92$

All norrmerts ad siges are in sood corditra. Repars mate is fill 2004 look very goos ard vegetation isestablah

10 throw ghat the site. No issures woted.

1154 - CAU 424LE 3-6 Photos $91 \& 90$

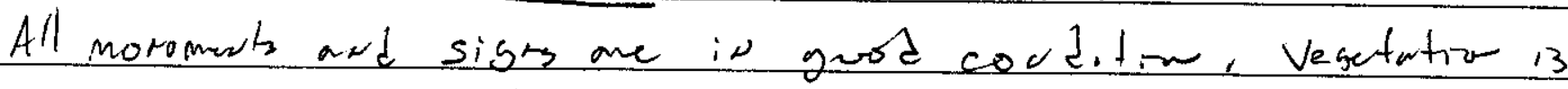
well estrblish. No issiez notas

1212 - CAU 424 LF 3.5 Photos $84,88 \% 87$

15 All mowments and sises are in good cortitiz. Vegetatro is Sparae, It appears the aven ord lardfll cover have beer recentlo

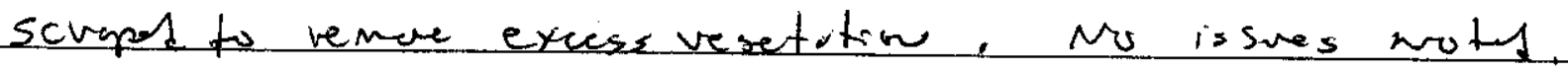

1246 -CAU 424 LF 3-3 Photos $86,85,84,83,82,81$

All above grous ard at grade moumerts were locoted and were in good cordition. No veretoture was present avoud the of-grote nowmects and sove spance vesetotia was plest venr the abore-grode nonumeats. No issues poted

$$
1332 \text { - CAU } 424 \text { LF 3-8 } 77,76,75,74
$$

Thiee of for at grate murvmerts were locoted and whe is geos cordition. The fourth at guade norumet is withis a radiolosicall cortholled aven and is covors by materiel stonos in th yard. The morumert will he vovified is futoone inspeations wher He matebial is vemons. No issues rotes

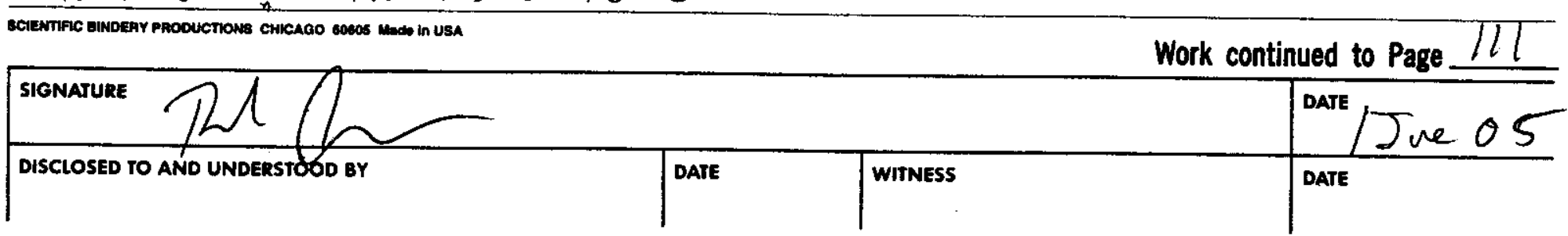


PROJECT NO.

111

Work continued from Page 110

BOOK NO.

TTR POl cost.

1336 - CAU424 LF 3-4 Photos 73,72,71,70,69

All abogrole mowers and signs were locates ard war is gars condition. Ore at grote moment waslocotee and 5 ode rear the rod was apparently cover by grand and will he Evaluate usia a metal detector diving the rest inspection. Repair mode during fall 2004 look very goo l ard vegetation is

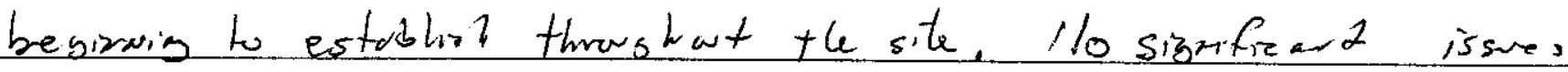
noted at this time.

101400 - CAV 407

Photos 68,67,66,65,64,63,62,61,60,54

The cove, fere, and signs are in good condition. Yejetutio is begiserio to become well establols ard his geod covenger or the coven. Irrigation will costive until completion is determine by the biologist. No issues noted.

151417 . C AU 404

Photo $358,57,56,55,54,53,52,51$

The cover, fere, ard signs are is good conditions. Vegetation is well established within the ferne ard on the coven. No issues notes.

1441 - CAV 400 Doublet Pit Photos $50,49,48,47,46,45,44,43,42,\left(4400^{\prime}\right.$, 20 Fere ard sises are is geod condition. Vegetation, 3 well estoblipld ard is really as good as that astride of th fere. Collected tallow coovdireto fo PCI REP. No issues rot ed 1514 - CAV 400 S Points LF Photos $39,38,37,36$ fere and sizes are in geod condition. Repairs complete durras 25 foll 2004 look vary good ard revegetation is establishing nell.

No Bower wo ts

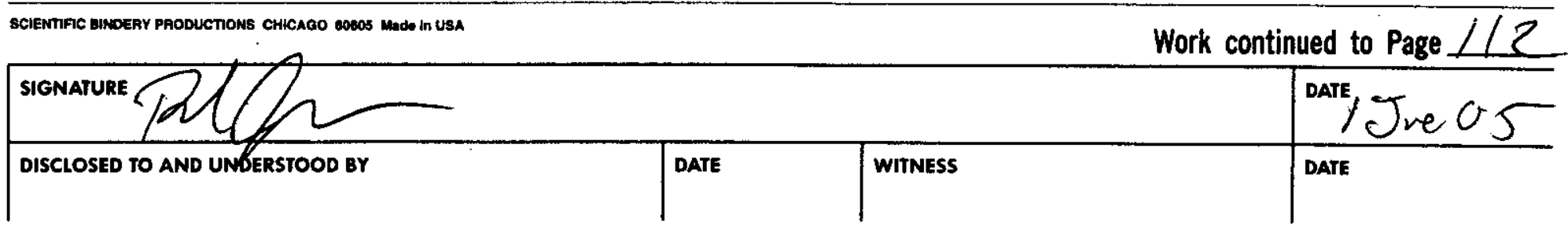


112 TITLE

Work continued from Page $\mid 11$
PROJECT NO.

BOOK NO.

TTR POl Cont. 2 June 2005 withe clem, warm

B. Jacks an

K. Cobble

0745 CAV $487 w$ A8 Photos 35,34,33

All monumerb ard sises ak present. The Northwest corner monument

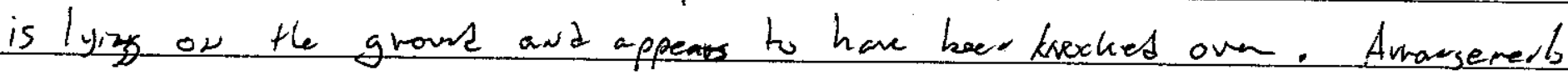
5 will be make to hae the moment set upright. No signifreat issues notes of this tire.

0821 CAv 487 E Alt Photo 3 $32,31,30,29,28,27,26,25,24,23$ All monuments ard sizes ave present. The $S E, N E$, ans NW monuments are lying on the ground ard open to ho re bead knocks over. The 10 ale hoof prints aA hove dropping avows the NE monument. The NW ard SE monuments are crocks and panticll, broker around the top. Arrangements will he made to re set the monuments in the grans and repair the broken tops. No other issues were roth. Repairs will he completes prion to the Foll 2005 inspections (Confirms with Kevi-Cobble).

${ }^{15} 1047$ CAV 426 Photos $15,14,13,12,11,10$

Ferne and sizes are ir geod condition. Vesetertion is

well establish and health thrasher th site. No issues wot es

1243 CAv 427 Photos $9,8,7,6,5$

20 All leach field markers (bed rock covering metal plate) ware locator and determines to be in good condition. No issues notes.

1321 CAV 423 Photo 1

The sign marking the UDP was located ard was in gad condition No Busies notes.

${ }^{25} 1348$ CAV 453 Photos 4, 3,2,1

ferries, sises, as d mowers wee all ir good couditrar.

No issues voted.

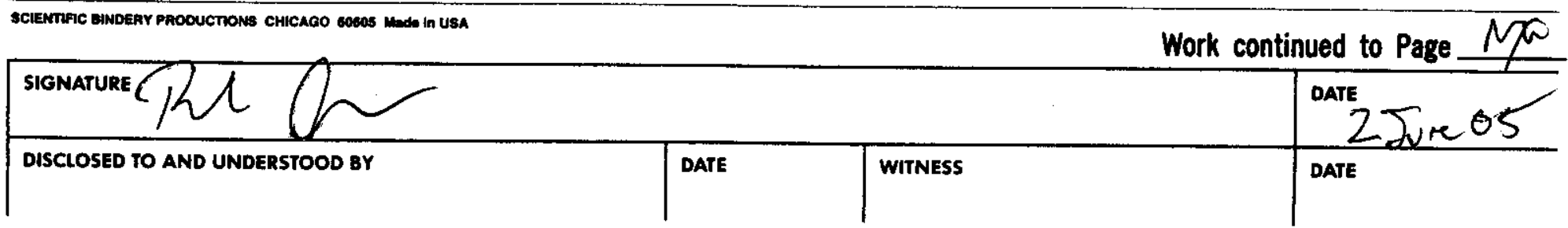


TITLE

Work continued from Page $N / A$
PROJECT NO. TTR PCI

BOOK NO.

113

20 June05 weath wam-clear - B. Jacksa Punpose of visit to $T R R$ is to corfim masuterme actritis at CAU 487 to set upwizt the above growed nowreuts at CAU 487 locetions 4.8 ard A-17. Also th 5 camen uses to tre photos duris the $1-2$ Jure 05 inspection molfurction ard photos fa 424 CF cell A3-3, A3-5, ad A3. 8 were panticllt damages. Replocement photos wae toker a 20 Jee 5 fa thece aves.

${ }^{10} 0815$ - 487 A-8 $8 A 17$ - above guose monumils hae beer set upinght ard are is gerd condition. Westimghone is obtaries a polyma cemert to fill the crock or the crockes morvmert tops.

150943 - Tave additionl plotos of CAU 424 Irodfal cills to replace the domas files fin the 1-2Jue05 irspector.

1307 - pet with Jous to discres logistis fa suppont ot pipe vemount at CAN 423 .

20

25
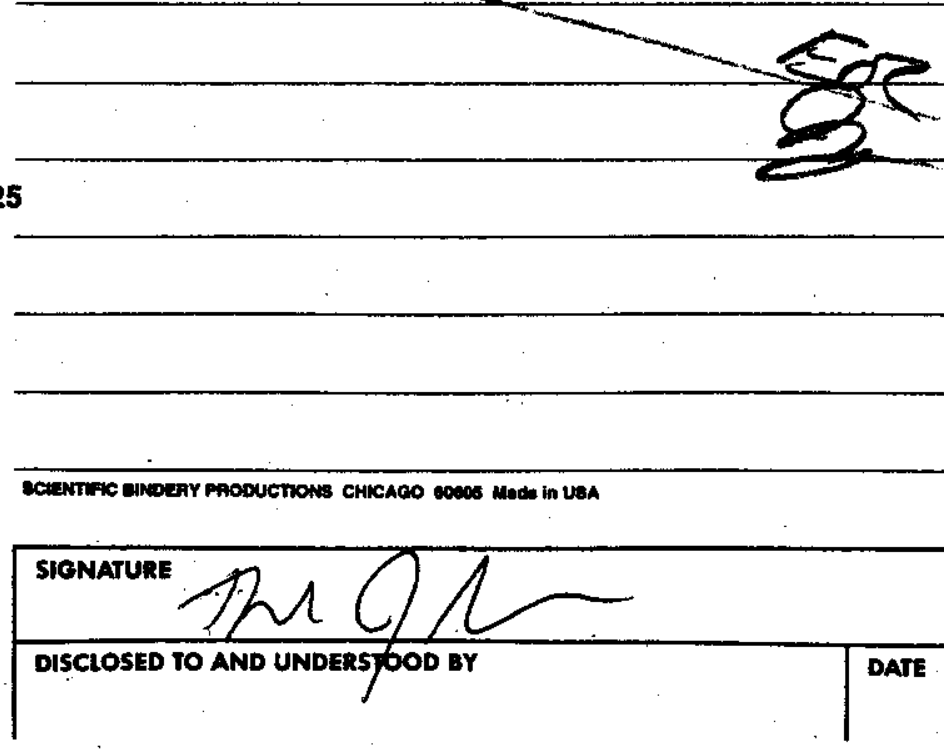

Work continued to Page

DATE

WITNESS

DATE 
128 TITLE

Work continued from Page $N / 5$
PROJECT NO.

BOOK NO.

Tue 15Nov05

TTR PCI

wertha: Surax, Calm, cool

B. Jackor, K. Cabble, T. Zaferatos

1408 - 400-5-Poids LF

i Fereing ard siges ave all in gerd condition. Vegetator in the middle of site is still sparre de to revesotetra iv 2004. 6Photos

1432 - 400 . Borblut P.t

Fercirz and sisers are all is gord cordition. Vesetation

o remairs well establishs. NNSA/NOER subgestat proposing to vemore the ferce a fta vext years (2006) irspectiozs. 3 photos

1445 - 404 - Rollen Costa Seren Laeor

Fencion add signs are all in guod condition. Sore mina burrowin and berdies of robol fearing alon east sule. Vesetation 5 ard cover ave in geod condition. 7 photos

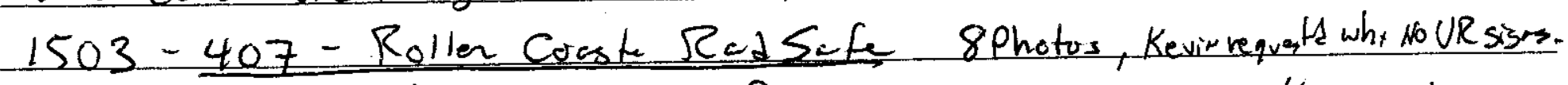
Top strard of barbod-wive ferein was broker on the south sile of site, appose $200^{\prime}$ exterdig fron gate to the erst. A rod postirs sise

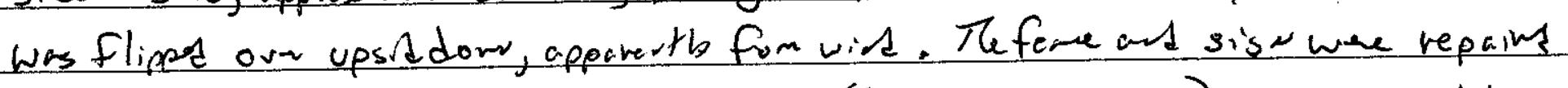

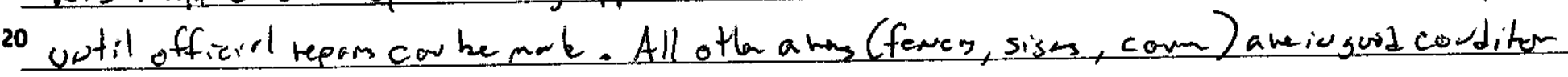
iS21-426-Cacts Spring 4 photro

Fereing and signs ane in geod cordition. Vesetution is well estoblets and the 13 no evosion or the coven.

251535 - 1621 - peet with John Hillard AF-EOD

1632 - 424-A3 Landf.ll A3-5 2 phots

Monumerts and sigar ale id gerd coclition. No grov Ad dis turbare withiv UR.

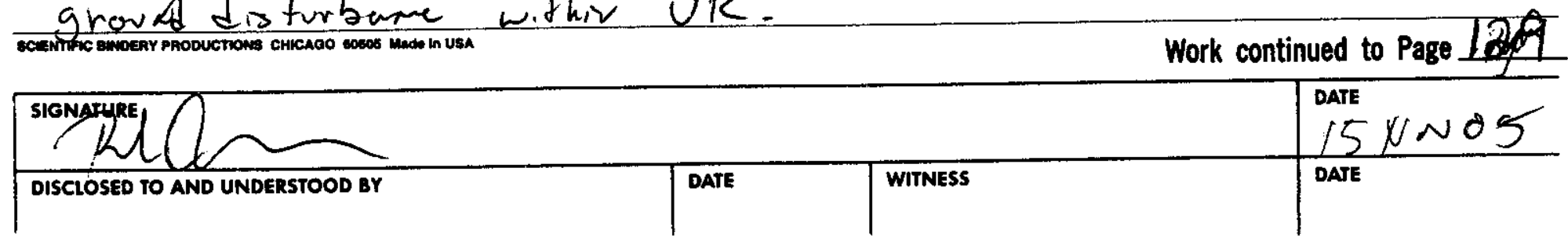


TITLE

Work continued from Page 128

Tue 15Nov05

TTRPCI - coutirves

129

$1645-424-A 3$ Landf.11 A3-8 4 photo

5 Ove atgrode nowment at the southwest conrm of 46 site cortimes to be covend by sardic recycling dabm and car sot be visullle irsperts, howern the ak mo signs of groved distorbore ard the nowment is expecters to be presed. All othe at-grote morevmedts were loceths

10 and are in good condition

$$
1703-424 \text { A3 Lardfill A3-4 4 Photes }
$$

Monvmedts art sises are in gool coulition. No grous distorbare within VR, 2004 repars look sous, cool vesetotion coverace, alhat cleet grass.

$151712-424$ A3 Lardfil A3-6 3 Photes

Morrmert a 1 sises are in sub condition. Mo grourl disturbare withir VR.

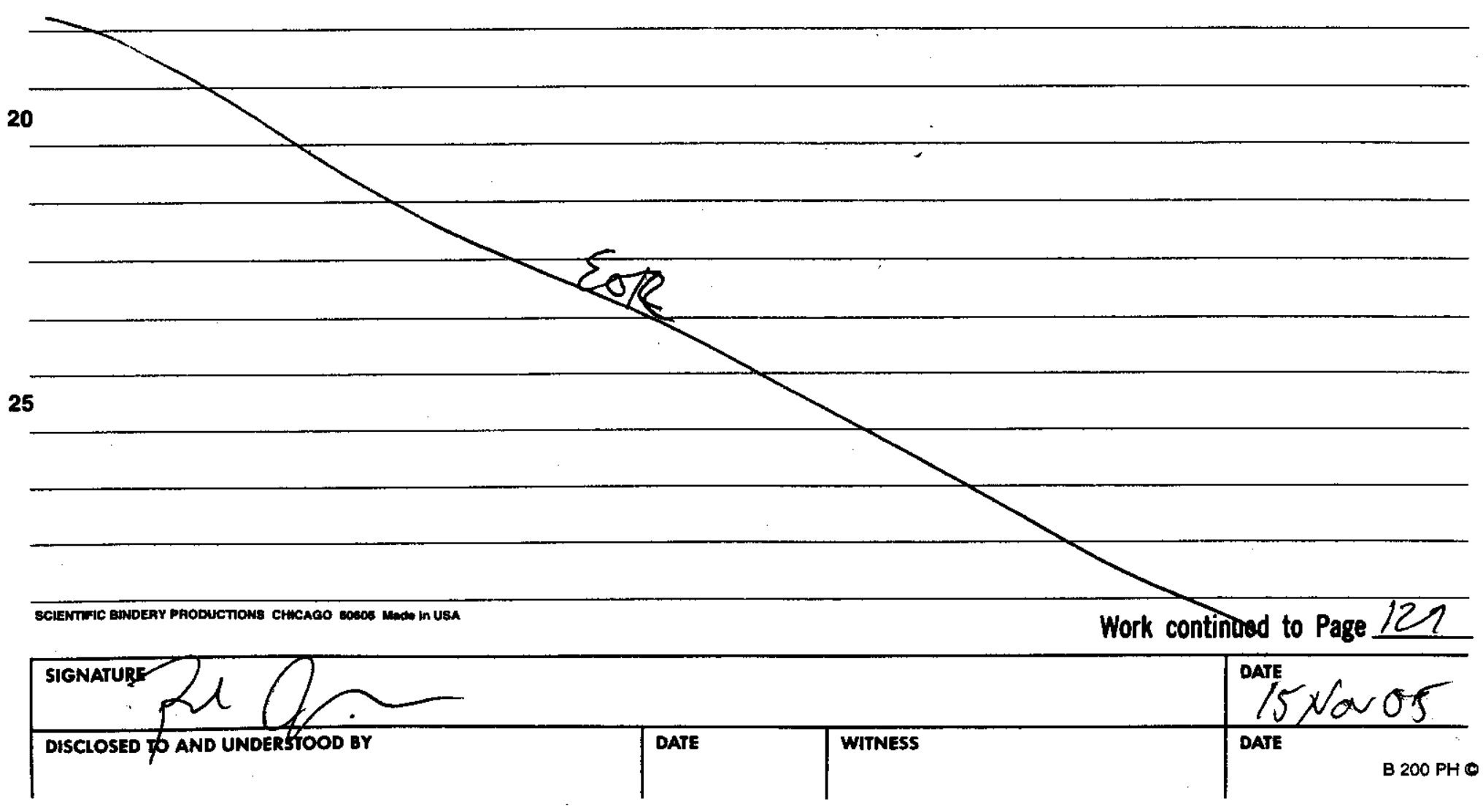


130 TITLE

Work continued from Page D/A 129
PROJECT NO.

BOOK NO.

Wed 16 Nov 05

Weath: Sorat, lishtbuere, cool

TTR PCl - covt.

Br Jocksa, $K$ comle, T. Zaforatos

S.Burrison, GR Richarisor

$50907 \quad 427$ A3 Septre S7sten 2,6 13 photos

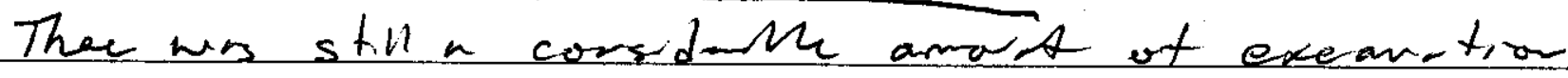
activits arous $\mathrm{B} / \mathrm{d}_{3}$ 0370. Lerohfield bourdaries were measumes off of bvilding corvers ard it wrs corfirms tht ro excartions were withir the UR Borrdarios. The remairing UNdistorbet aves wen inspectes ard all cormen, evrdest by red rock, wer present ad in sood costition. NNSA/NDEP reparts that covmers subsurface plates be reploied by at-grade a slizhtly subgrate nonmeats. A plaw shory be inches iv the $2005 \mathrm{PCl}$ repart.

1025423 Aner 3 VOP 1 Photo

The morrment and sise wae irtent ard it geos cordition. The scope fo pipe remurl was discrsst. 1038453 A 9 VxO LF 20 photos

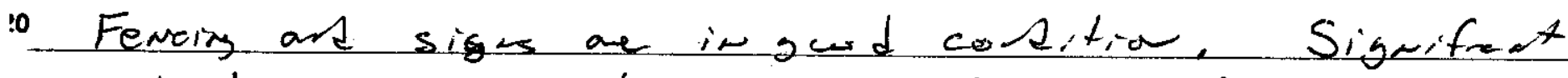
subsudeme is presert in the erst end of croll A9-3 sevenl aveos of subsidere of $1-3$ fect are prest iv the eastere es acd ore larne arn of upproximets $70^{\prime}$ by $30^{\prime}$ was preset in the east.cedtrl arm of the A9.3 celletithsore mina subsider consistics mainle of a $\sim$ - fout $\phi$ hole with uskrom depth. This site requins imnedroth veparrs ir accodare with the CR. Subsideme plesert ir Aq.1 \& $A 9-3$

SCIENTIFIC GINOERY PRODUCTIONS CHICACO 60606 Made in USA

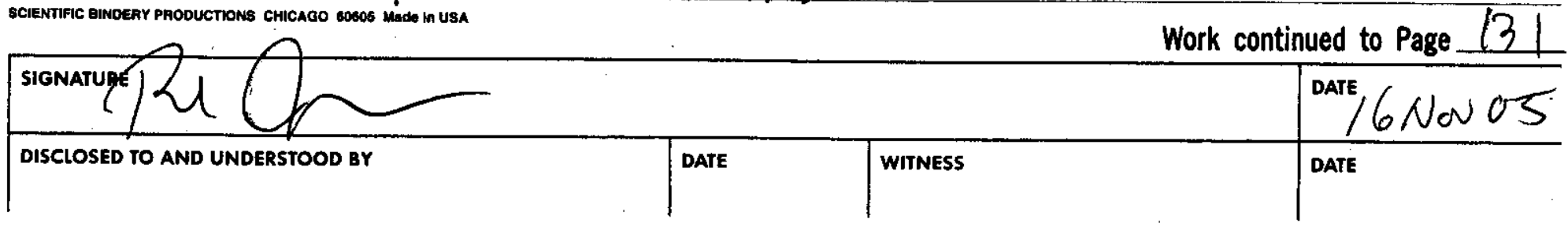


TITLE

Work continued from Page 130

Wed 16 Nor 05

ITR PCI-cont
PROJECT NO.

BOOK NO.

131

1055487 A17 Thurdervel 5 photos

5 Three out of form above-grd covente mourmets are of the grourd a ppavertly pushed ove by hoorses (hoof prids and piles of duny are arourd th mownerts). The sare cordition wos woted in 2004 . Othan thas the norvmat isse, the sile is i2 guol conditia. Repais-

10 nad to uprisht the dowres moarmerh, burry decpa a set in corevete base. Repar brokerlerank morument tap.

1122487 AQ8 Thuderwell 4 Photers

Ore abore-gude coocrede moxumert is on, its side on the grond. Repair mon meats as deserihid fe Al7.

15 Ore adjacot mowurat has a cracked edd and vats to be repaind betar it breiks off.

$$
1255 \quad 424 \quad 43-2
$$

All monverls ard siges are in geod cordition. No signs of UR disturbarce. 2004 repars leok gord with ${ }^{20}$ good vesetotion coverase, albeet cleet grass.

$1312 \quad 424 \quad A 3-1$

All monnents and signs are in seol condition, No sigrs of UR distorbarce

$$
1321 \quad 424 \quad A 3-3
$$

${ }^{25}$ All abore-grole and at-grole morimeds ave in gow corditior, ard no signs of UR disturbane.

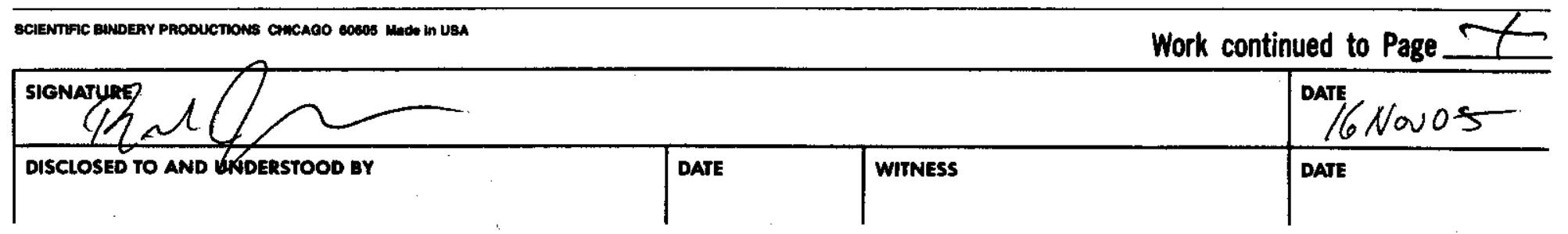


Post-Closure Inspection Report - TTR

Revision: 0

Date: June 2006

ATtachment E.

Photographs 
Post-Closure Inspection Report - TTR

Revision: 0

Date: June 2006

\section{THIS PAGE INTENTIONALLY LEFT BLANK}

E-2 


\section{PHOTOGRAPH LOG}

\begin{tabular}{|c|c|c|}
\hline PHOTOGRAPH & DATE & DESCRIPTION \\
\hline 1 & 06/01/2005 & CAU 400 Bomblet Pit, looking south \\
\hline 2 & $11 / 15 / 2005$ & CAU 400 Bomblet Pit, looking south \\
\hline 3 & 06/01/2005 & CAU 400 Bomblet Pit, looking west \\
\hline 4 & $11 / 15 / 2005$ & CAU 400 Bomblet Pit, looking west \\
\hline 5 & 06/01/2005 & CAU 400 Five Points Landfill, looking east \\
\hline 6 & $11 / 15 / 2005$ & CAU 400 Five Points Landfill, looking east \\
\hline 7 & 06/01/2005 & CAU 400 Five Points Landfill, looking east \\
\hline 8 & $11 / 15 / 2005$ & CAU 400 Five Points Landfill, looking east \\
\hline 9 & 06/01/2005 & CAU 404, looking east \\
\hline 10 & $11 / 15 / 2005$ & CAU 404, looking east \\
\hline 11 & 06/01/2005 & CAU 407, looking east \\
\hline 12 & $11 / 15 / 2005$ & CAU 407, looking east \\
\hline 13 & 06/01/2005 & CAU 407, looking southwest \\
\hline 14 & $11 / 15 / 2005$ & CAU 407, looking northeast \\
\hline 15 & 06/02/2005 & CAU 423, looking east \\
\hline 16 & $11 / 16 / 2005$ & CAU 423, looking east \\
\hline 17 & 06/01/2005 & CAU 424, Landfill Cell A3-1, looking south \\
\hline 18 & $11 / 16 / 2005$ & CAU 424, Landfill Cell A3-1, looking north \\
\hline 19 & 06/01/2005 & CAU 424, Landfill Cell A3-2, looking north \\
\hline 20 & $11 / 16 / 2005$ & CAU 424, Landfill Cell A3-2, looking north \\
\hline 21 & 06/01/2005 & CAU 424, Landfill Cell A3-3, looking west \\
\hline 22 & $11 / 16 / 2005$ & CAU 424, Landfill Cell A3-3, looking west \\
\hline 23 & 06/01/2005 & CAU 424, Landfill Cell A3-3, looking north \\
\hline 24 & $11 / 16 / 2005$ & CAU 424, Landfill Cell A3-3, looking north \\
\hline 25 & 06/01/2005 & CAU 424, Landfill Cell A3-4, looking north \\
\hline 26 & $11 / 15 / 2005$ & CAU 424, Landfill Cell A3-4, looking north \\
\hline 27 & 06/01/2005 & CAU 424, Landfill Cell A3-5, looking southeast \\
\hline 28 & $11 / 15 / 2005$ & CAU 424, Landfill Cell A3-5, looking southeast \\
\hline 29 & 06/01/2005 & CAU 424, Landfill Cell A3-6, looking northwest \\
\hline 30 & $11 / 15 / 2005$ & CAU 424, Landfill Cell A3-6, looking northwest \\
\hline 31 & 06/01/2005 & CAU 424, Landfill Cell A3-8, looking north \\
\hline 32 & $11 / 15 / 2005$ & CAU 424, Landfill Cell A3-8, looking west \\
\hline
\end{tabular}




\begin{tabular}{||c|c|l||}
\hline PHOTOGRAPH & DATE & DESCRIPTION \\
\hline \hline 33 & $06 / 02 / 2005$ & CAU 426, looking north \\
\hline 34 & $11 / 15 / 2005$ & CAU 426, looking north \\
\hline 35 & $06 / 02 / 2005$ & CAU 427, looking north \\
\hline 36 & $11 / 16 / 2005$ & CAU 427, looking north \\
\hline 37 & $06 / 02 / 2005$ & CAU 427, looking south \\
\hline 38 & $11 / 16 / 2005$ & CAU 427, looking south \\
\hline 39 & $06 / 02 / 2005$ & CAU 453, looking west \\
\hline 40 & $11 / 16 / 2005$ & CAU 453, looking west \\
\hline 41 & $11 / 16 / 2005$ & CAU 453, soil subsidence \\
\hline 42 & $11 / 16 / 2005$ & CAU 453, soil subsidence \\
\hline 43 & $06 / 02 / 2005$ & CAU 487, A-8 anomaly, looking southwest \\
\hline 44 & $11 / 16 / 2005$ & CAU 487, A-17 anomaly, looking north \\
\hline 45 & $11 / 16 / 2005$ & CAU 487, A-8 anomaly, fallen monument \\
\hline 46 & $11 / 16 / 2005$ & CAU 487, A-17 anomaly, fallen monuments \\
\hline
\end{tabular}




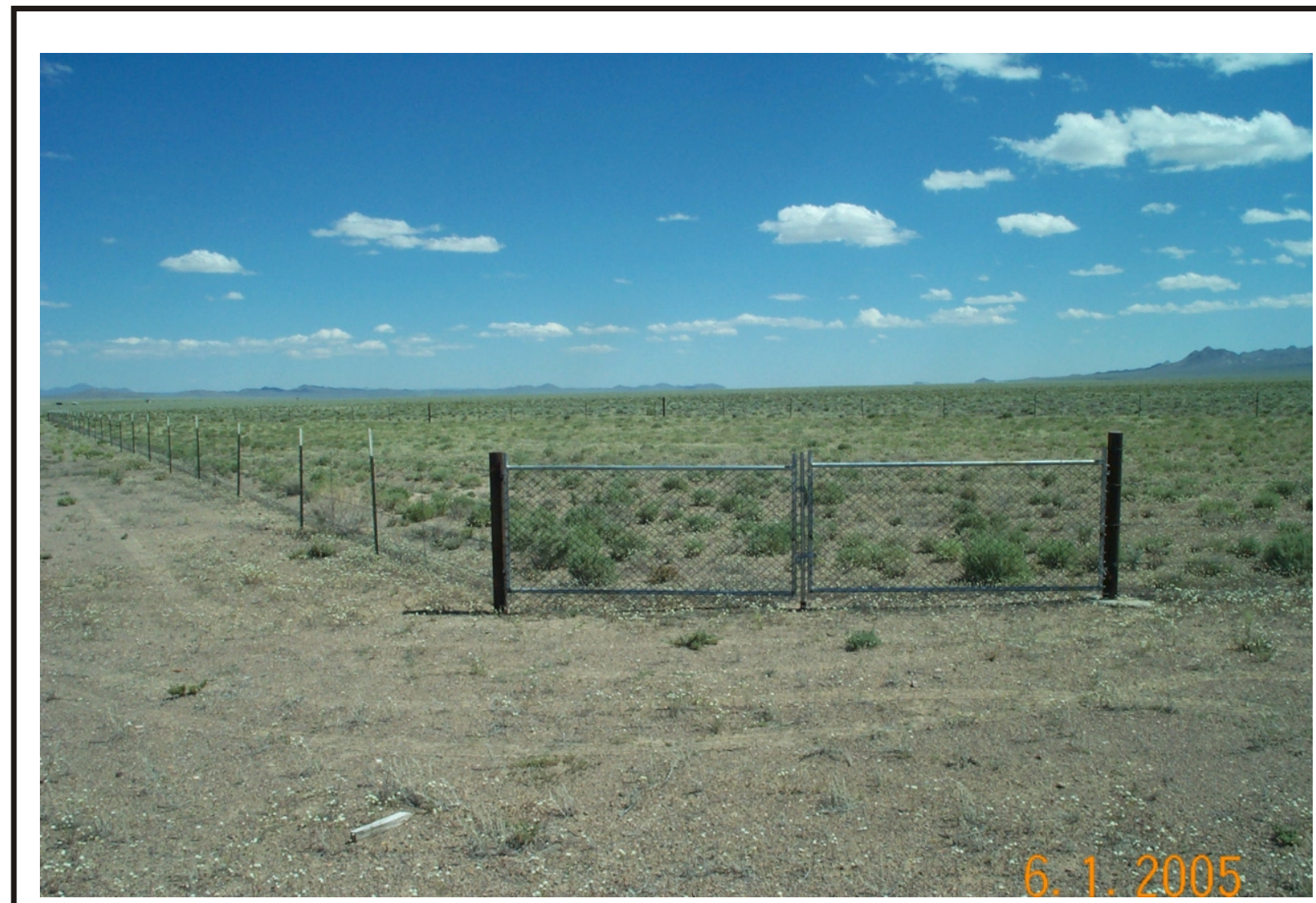

Photograph 1: CAU 400 Bomblet Pit, looking south, 06/01/05

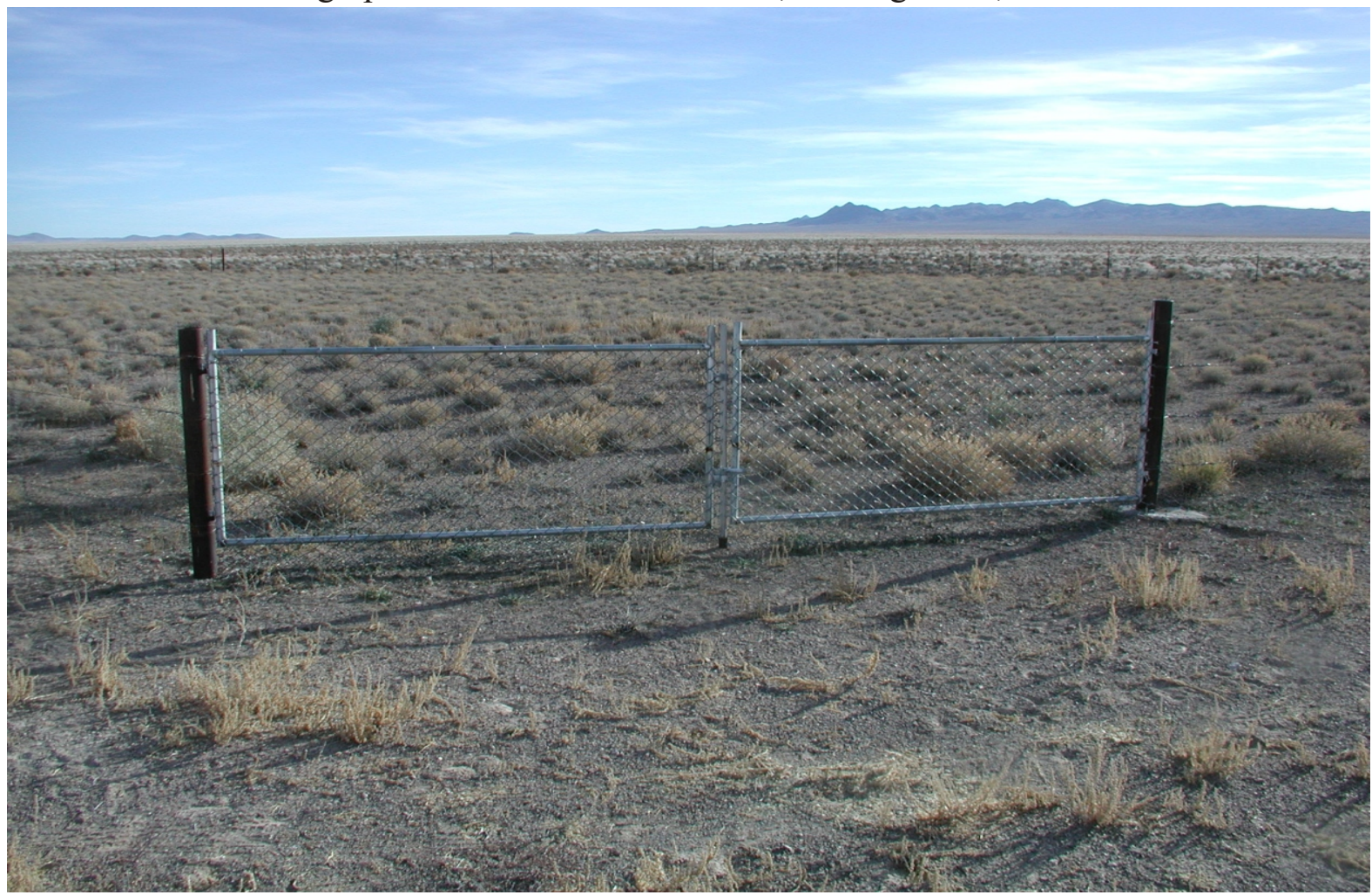

Photograph 2: CAU 400 Bomblet Pit, looking south, 11/15/05 


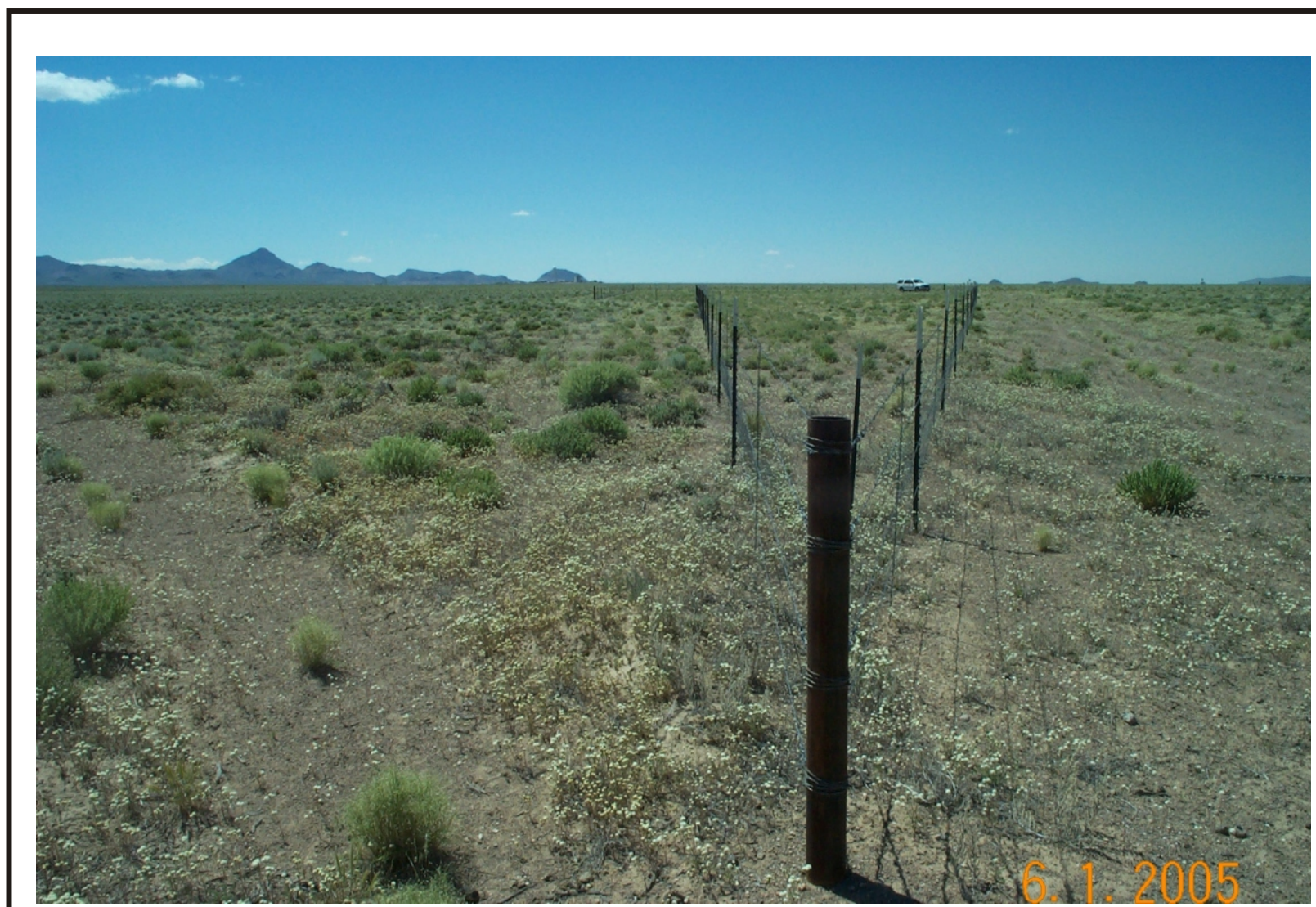

Photograph 3: CAU 400 Bomblet Pit, looking west, 06/01/05

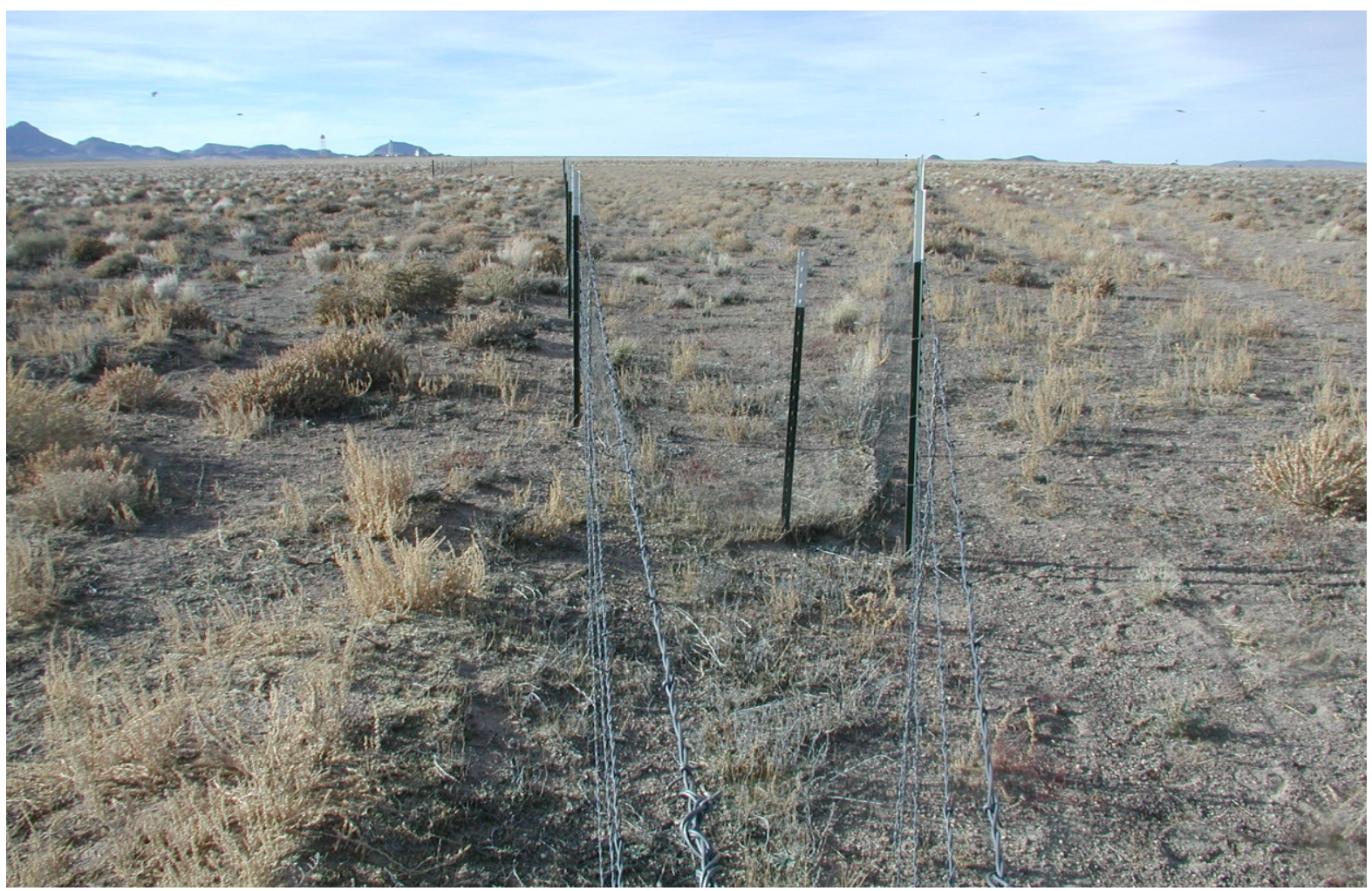

Photograph 4: CAU 400 Bomblet Pit, looking west, 11/15/05 


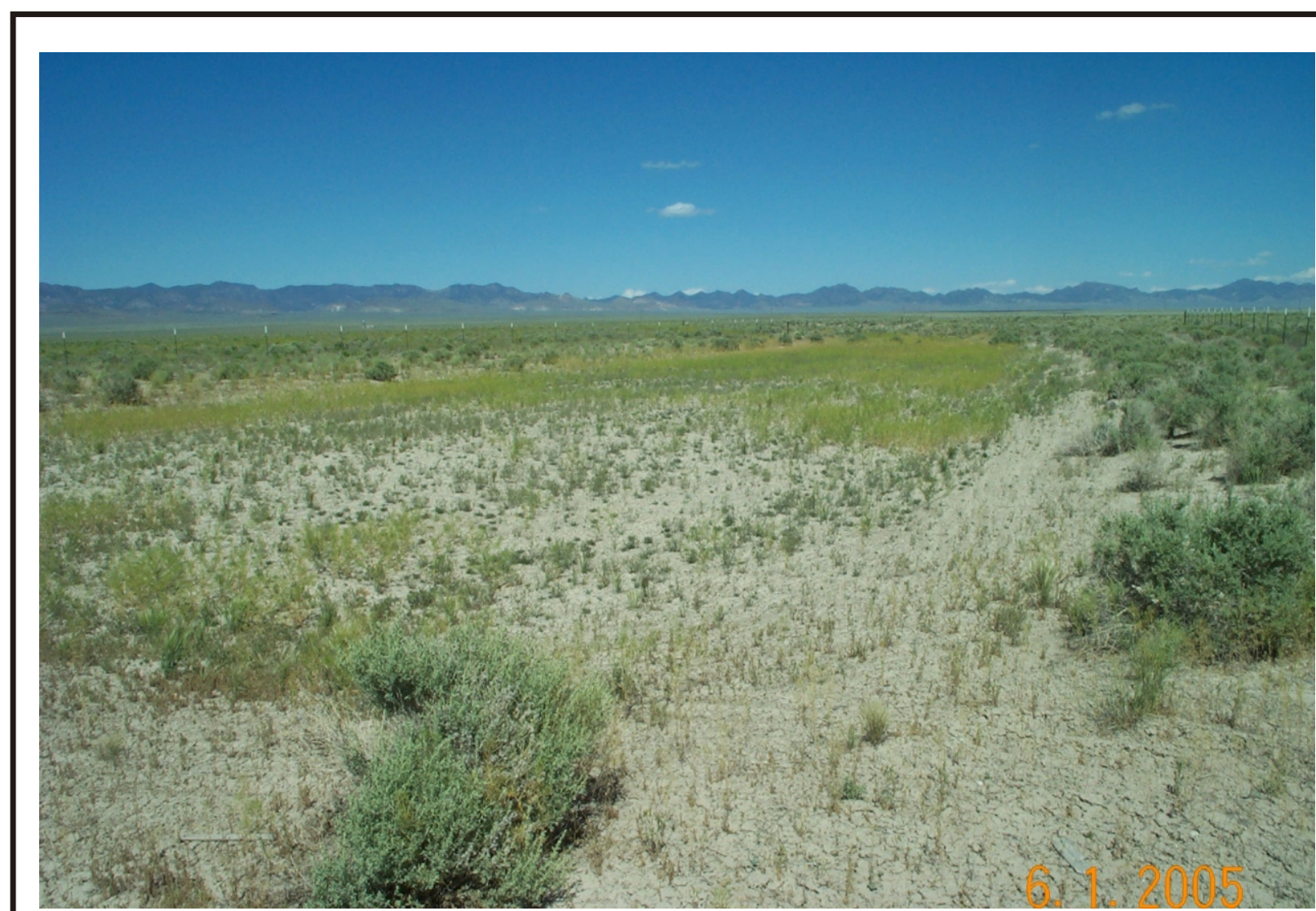

Photograph 5: CAU 400 Five Points Landfill, looking east, 06/01/05

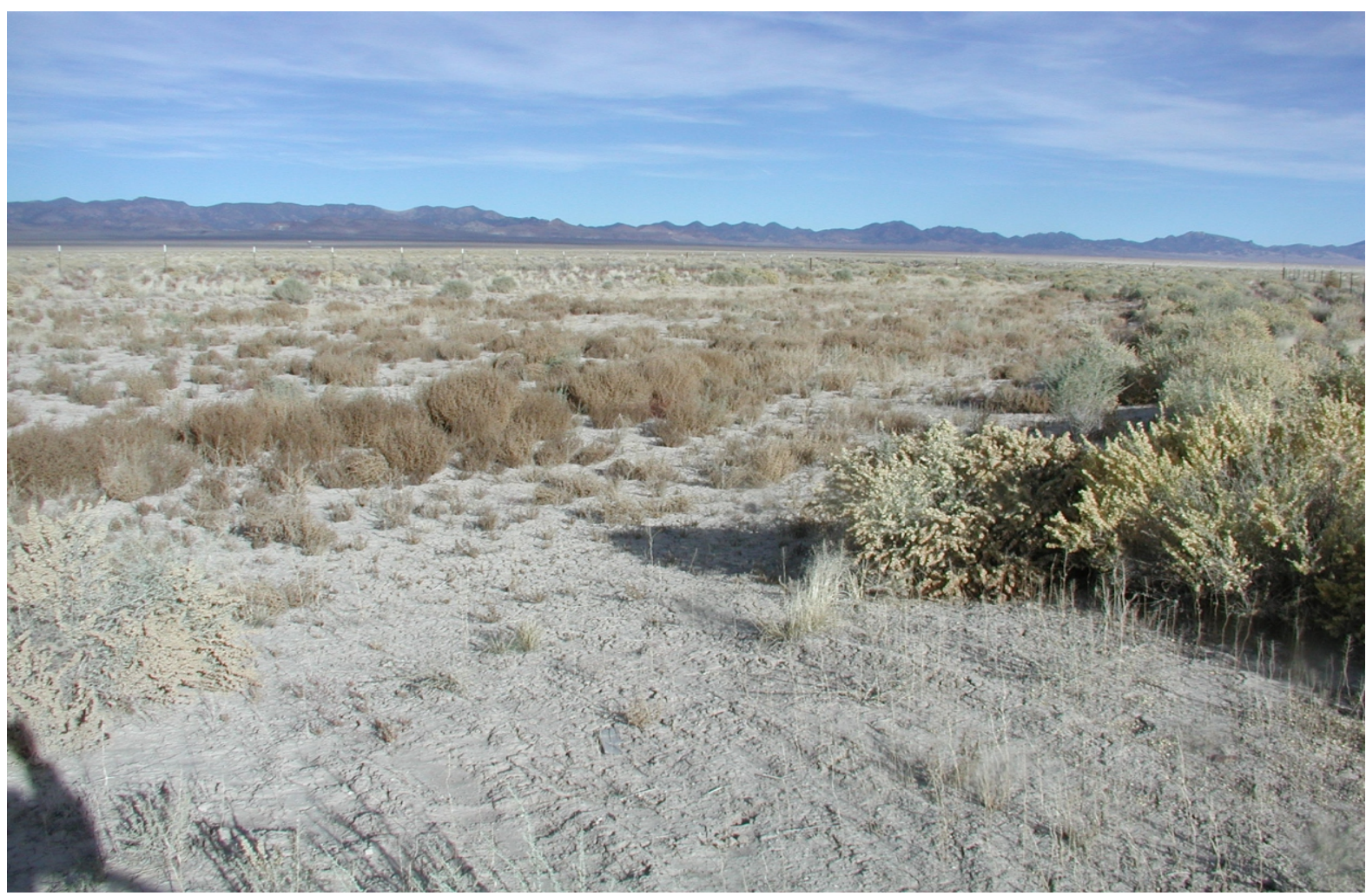

Photograph 6: CAU 400 Five Points Landfill, looking east, 11/15/05 


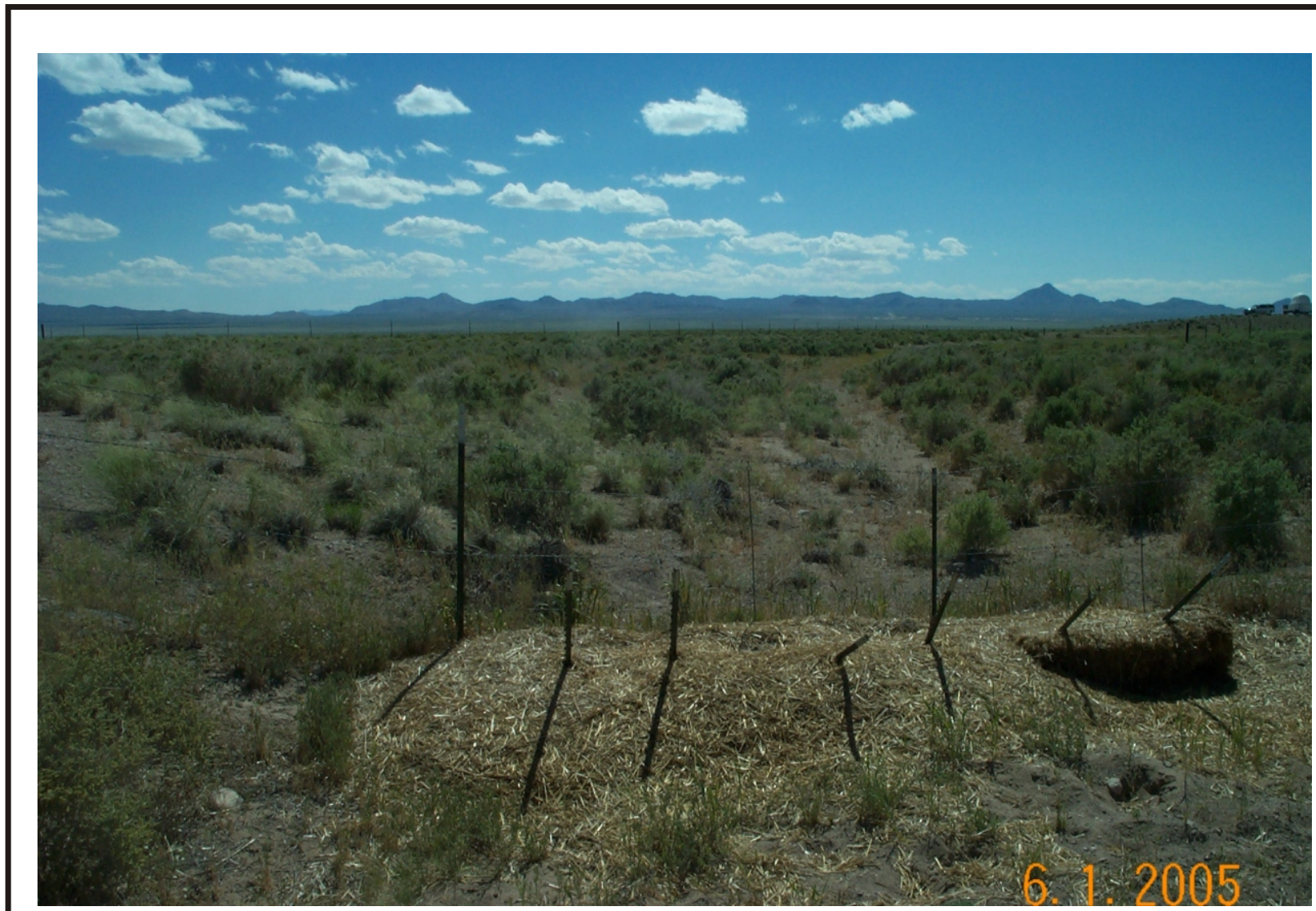

Photograph 7: CAU 400 Five Points Landfill, looking east, 06/01/05

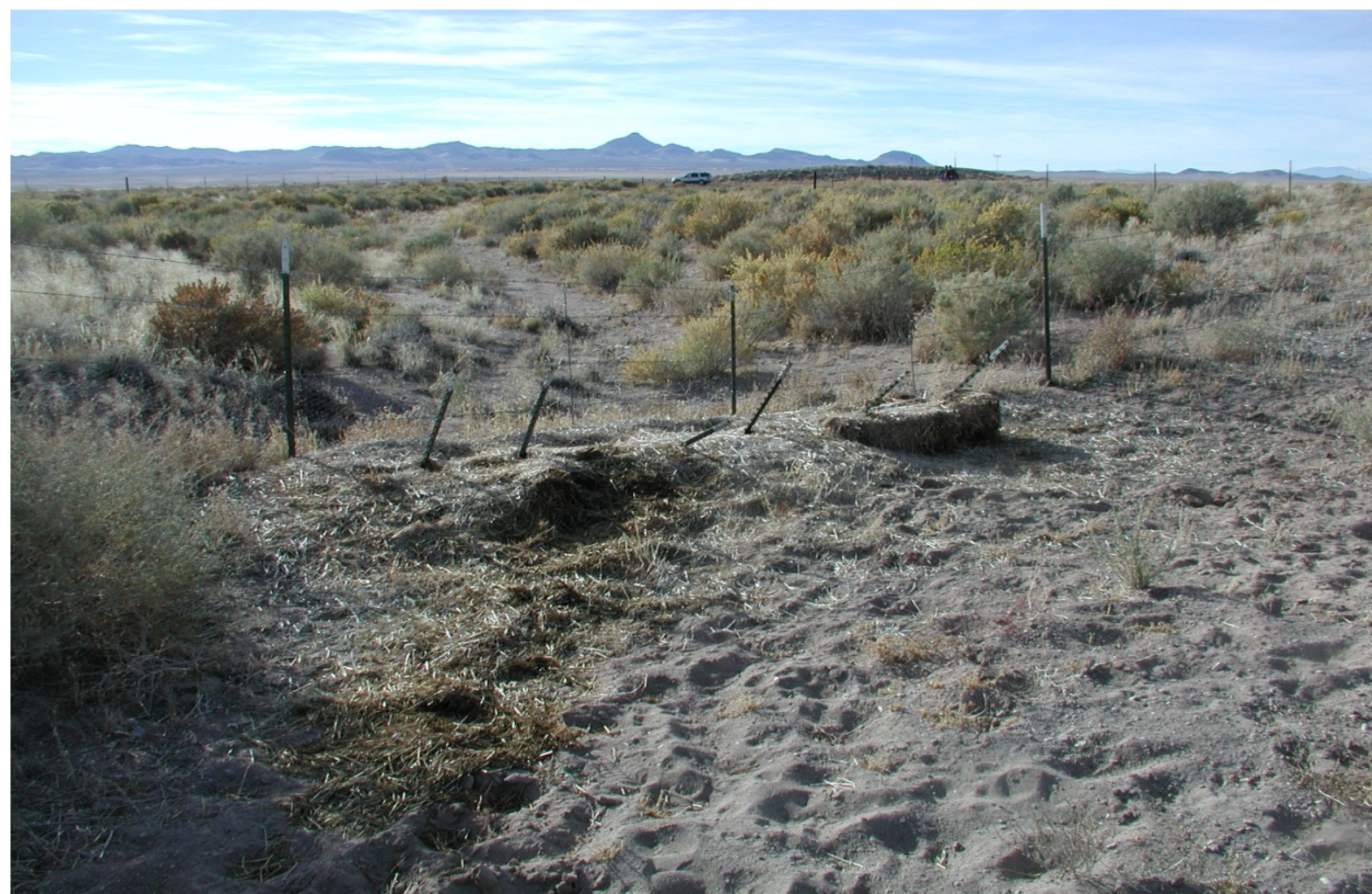

Photograph 8: CAU 400 Five Points Landfill, looking east, 11/15/05 


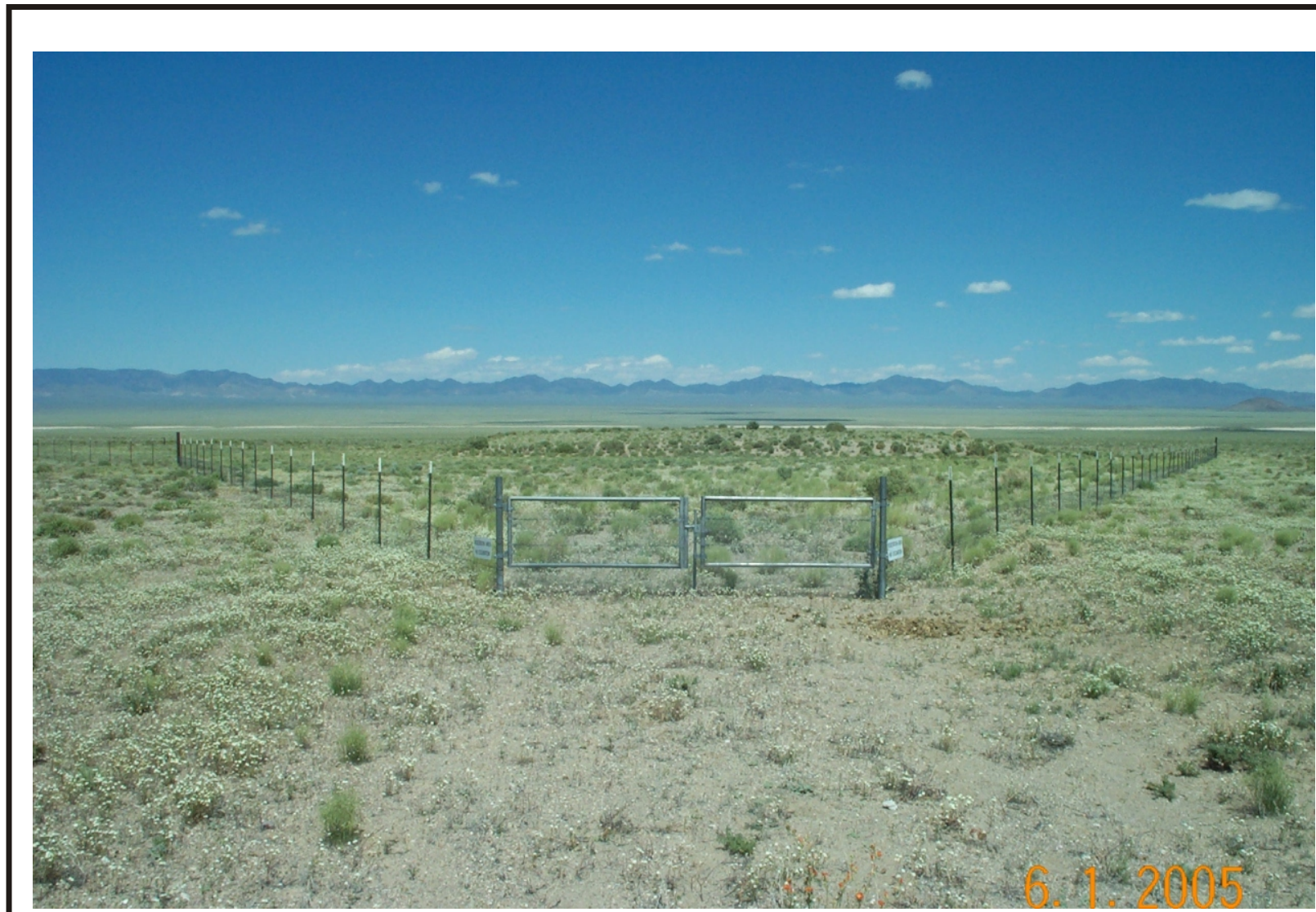

Photograph 9: CAU 404, looking east, 06/01/05

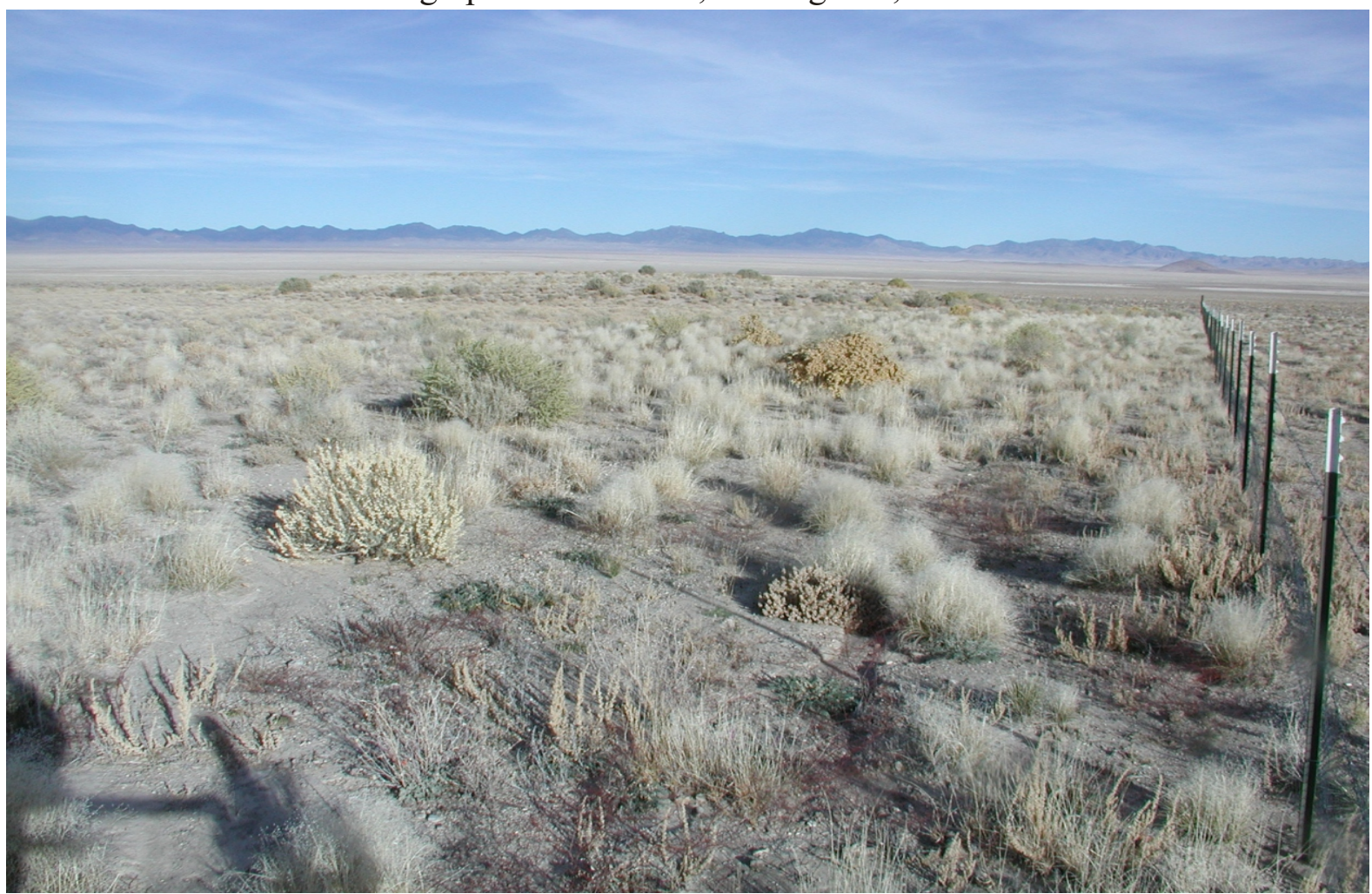

Photograph 10: CAU 404, looking east, 11/15/05 


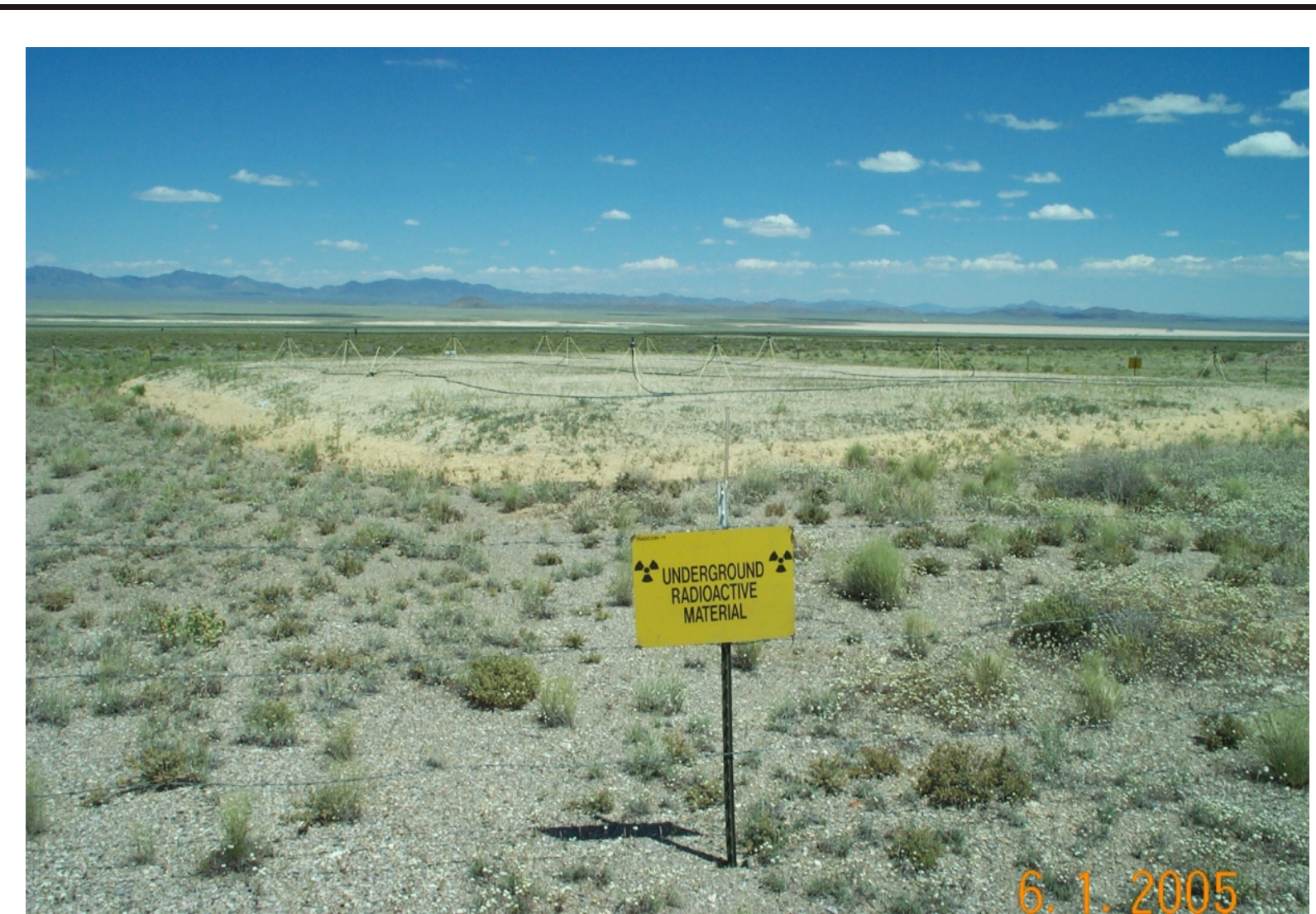

Photograph 11: CAU 407, looking east, 06/01/05

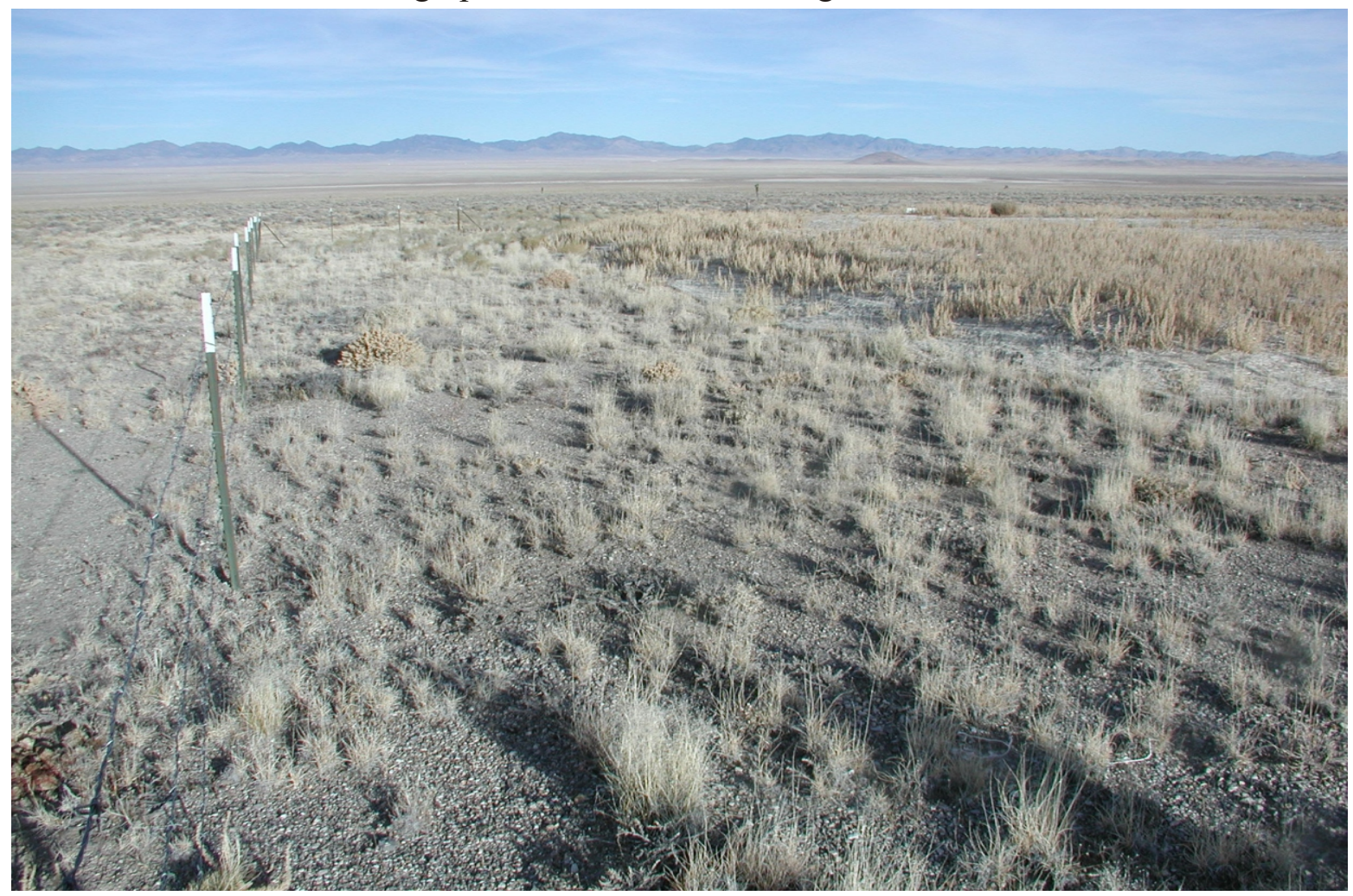

Photograph 12: CAU 407, looking east, 11/15/05 


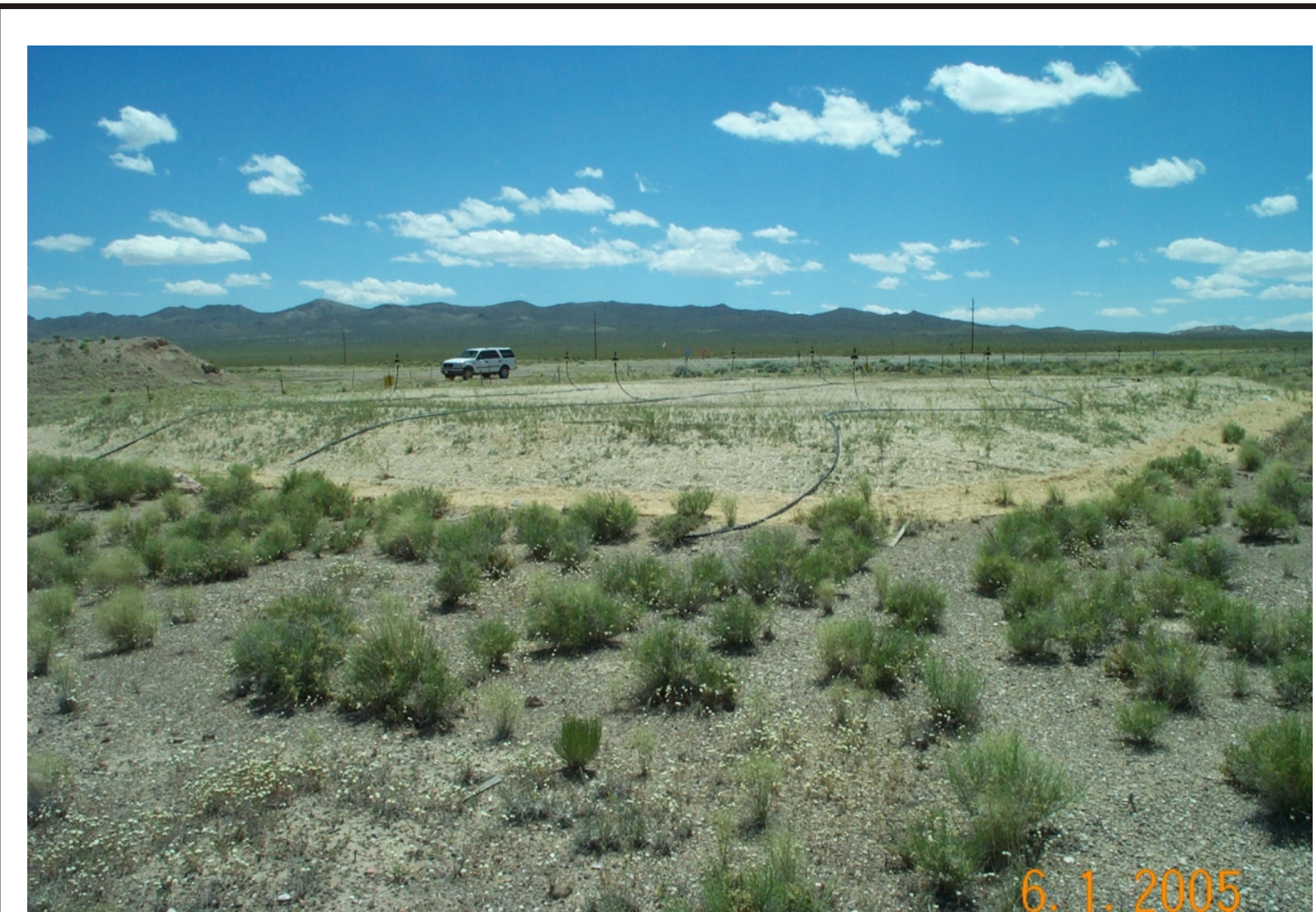

Photograph 13: CAU 407, looking southwest, 06/01/05

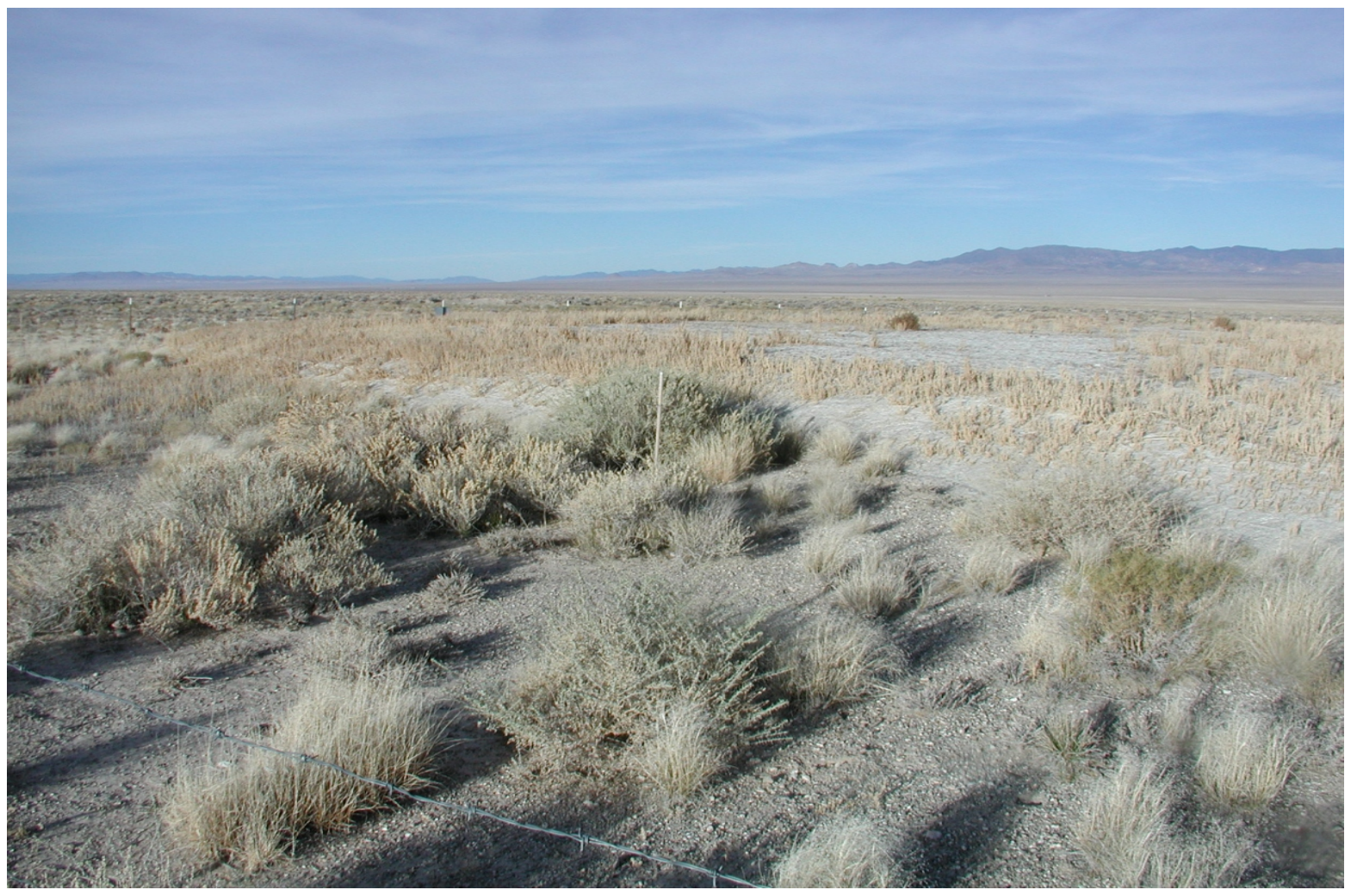

Photograph 14: CAU 407, looking northeast, 11/15/05 


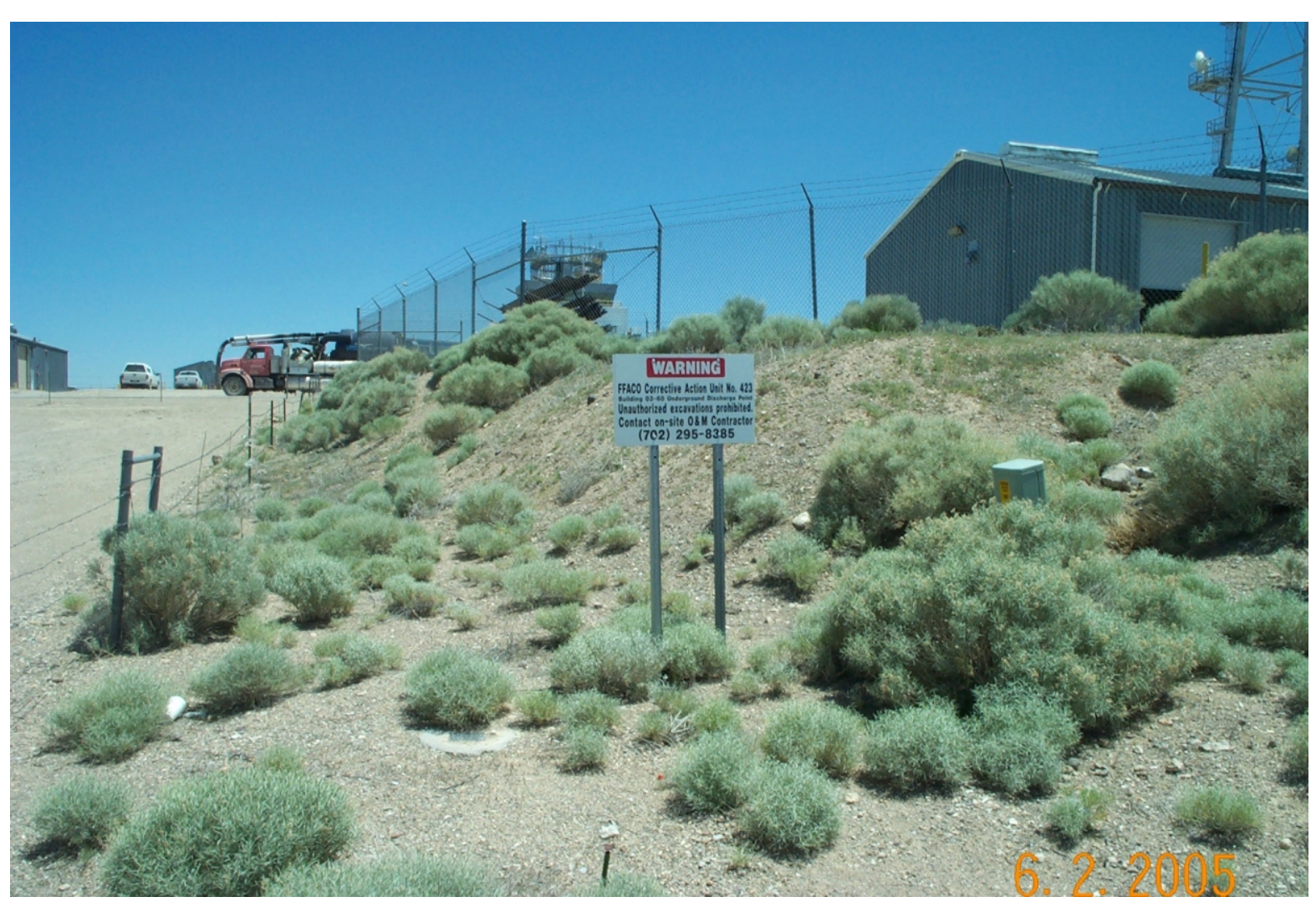

Photograph 15: CAU 423, looking east, 06/02/05

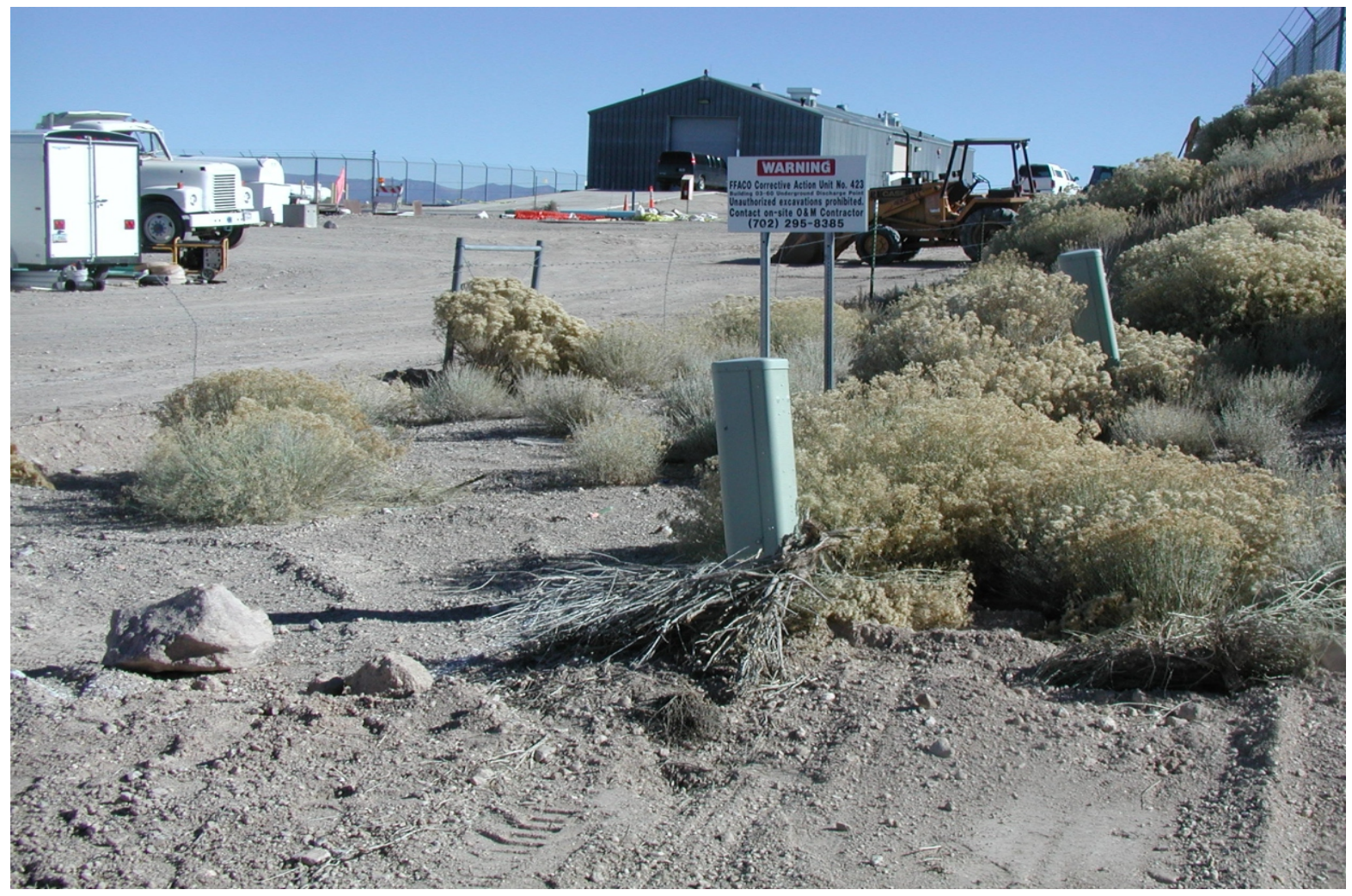

Photograph 16: CAU 423, looking east, 11/16/05 


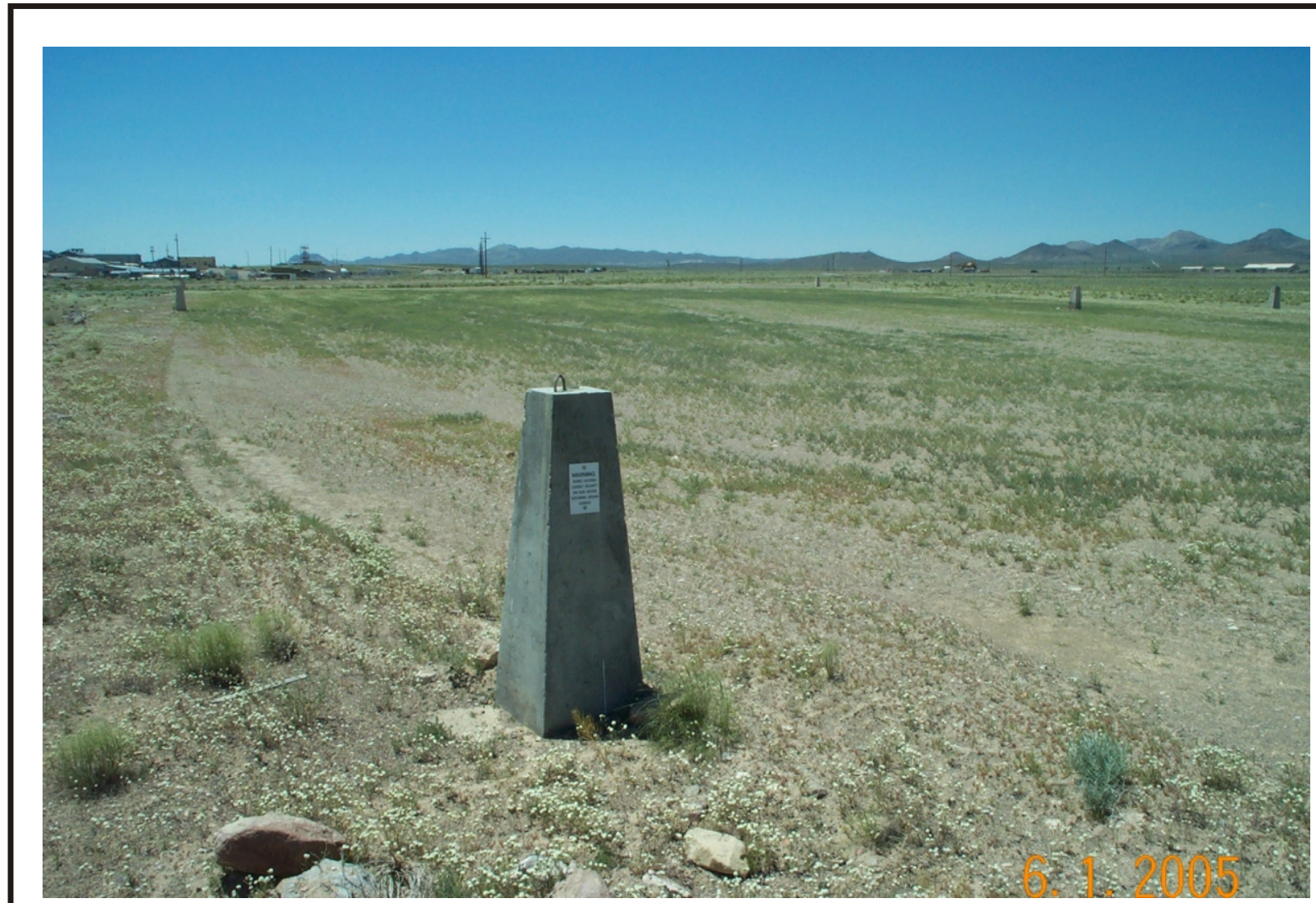

Photograph 17: CAU 424, Landfill Cell A3-1, looking south, 06/01/05

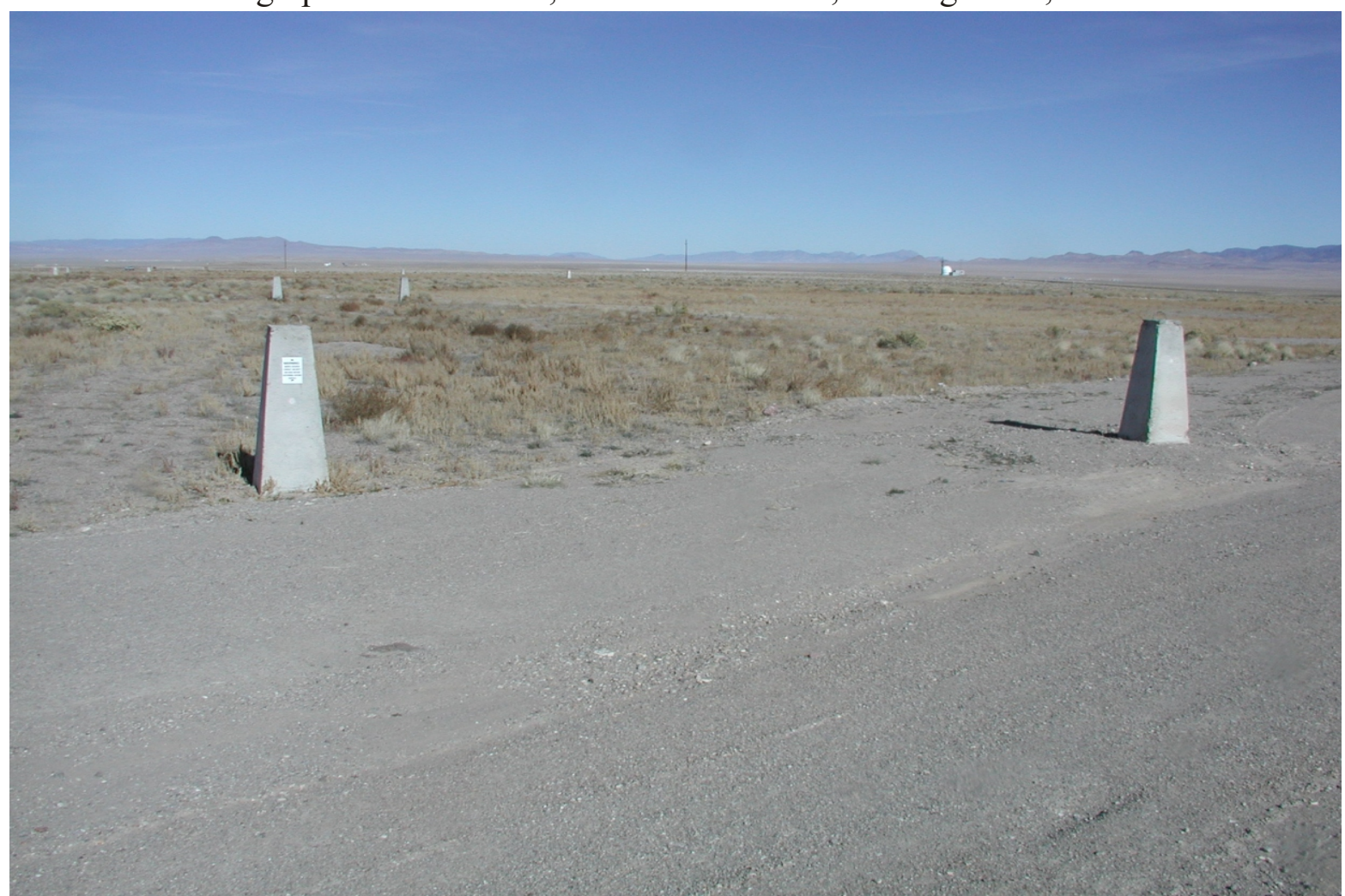

Photograph 18: CAU 424, Landfill Cell A3-1, looking north, 11/16/05 
Photograph 19: CAU 424, Landfill Cell A3-2, looking north, 06/01/05

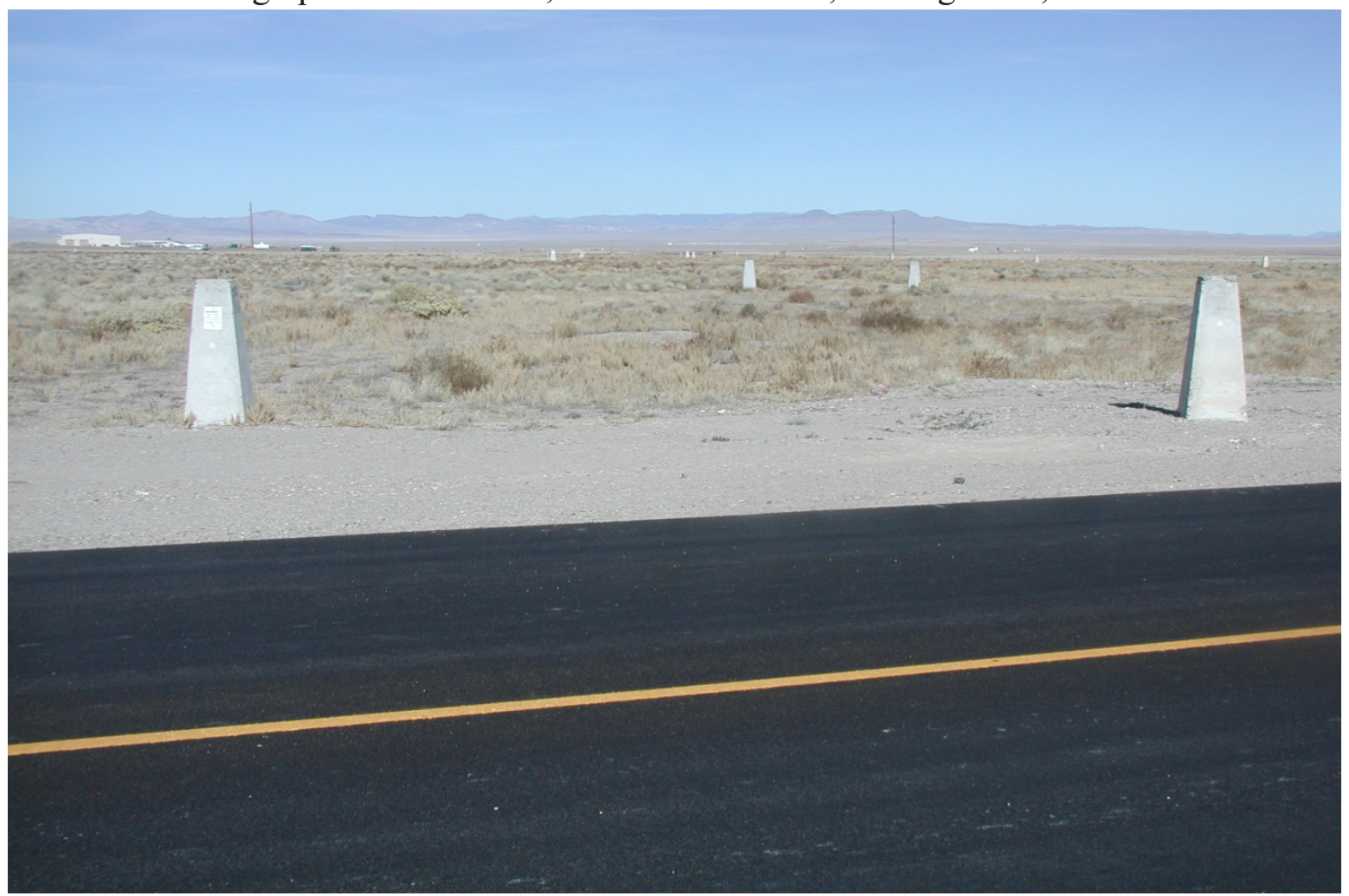

Photograph 20: CAU 424, Landfill Cell A3-2, looking north, 11/16/05 


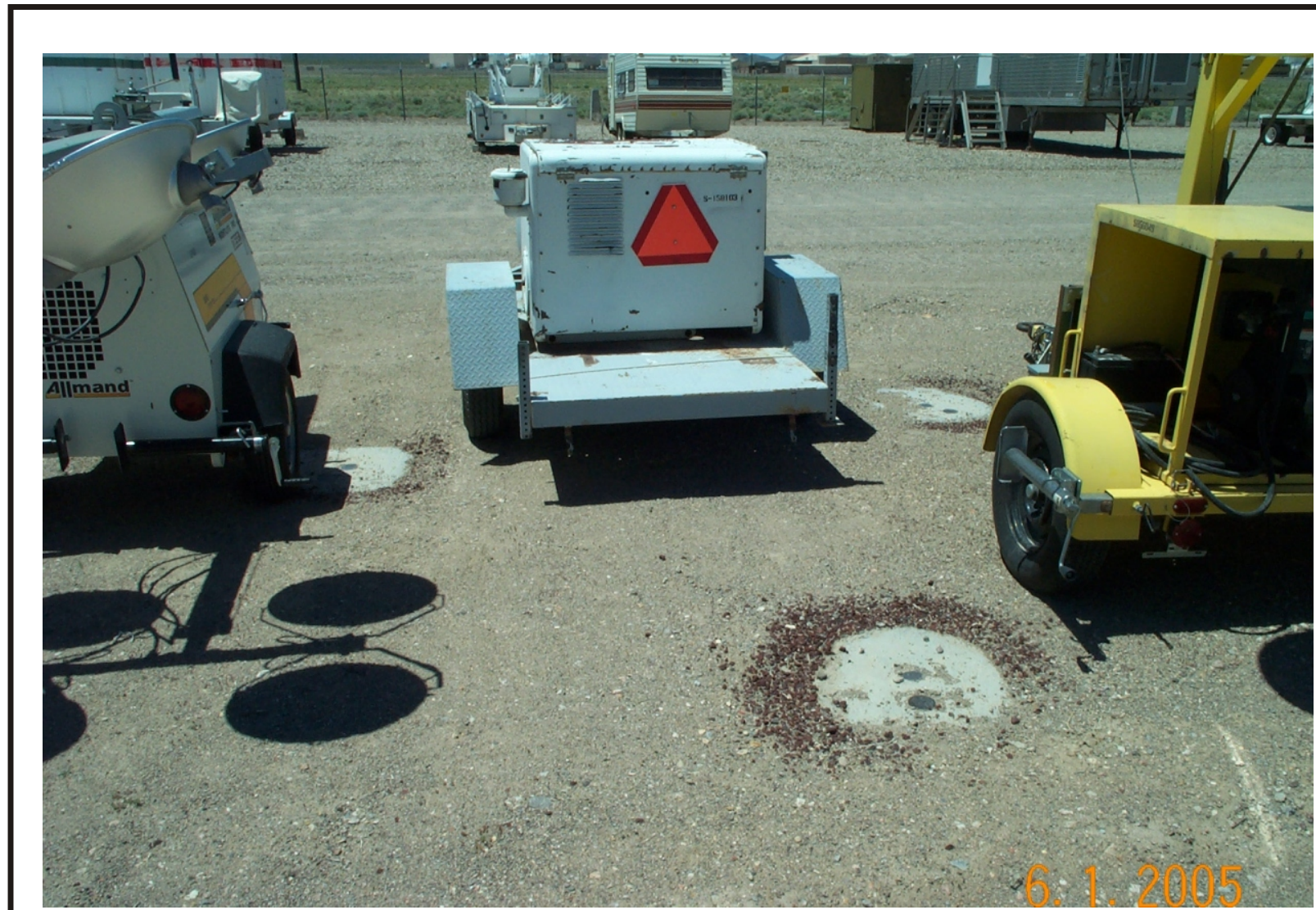

Photograph 21: CAU 424, Landfill Cell A3-3, looking west, 06/01/05

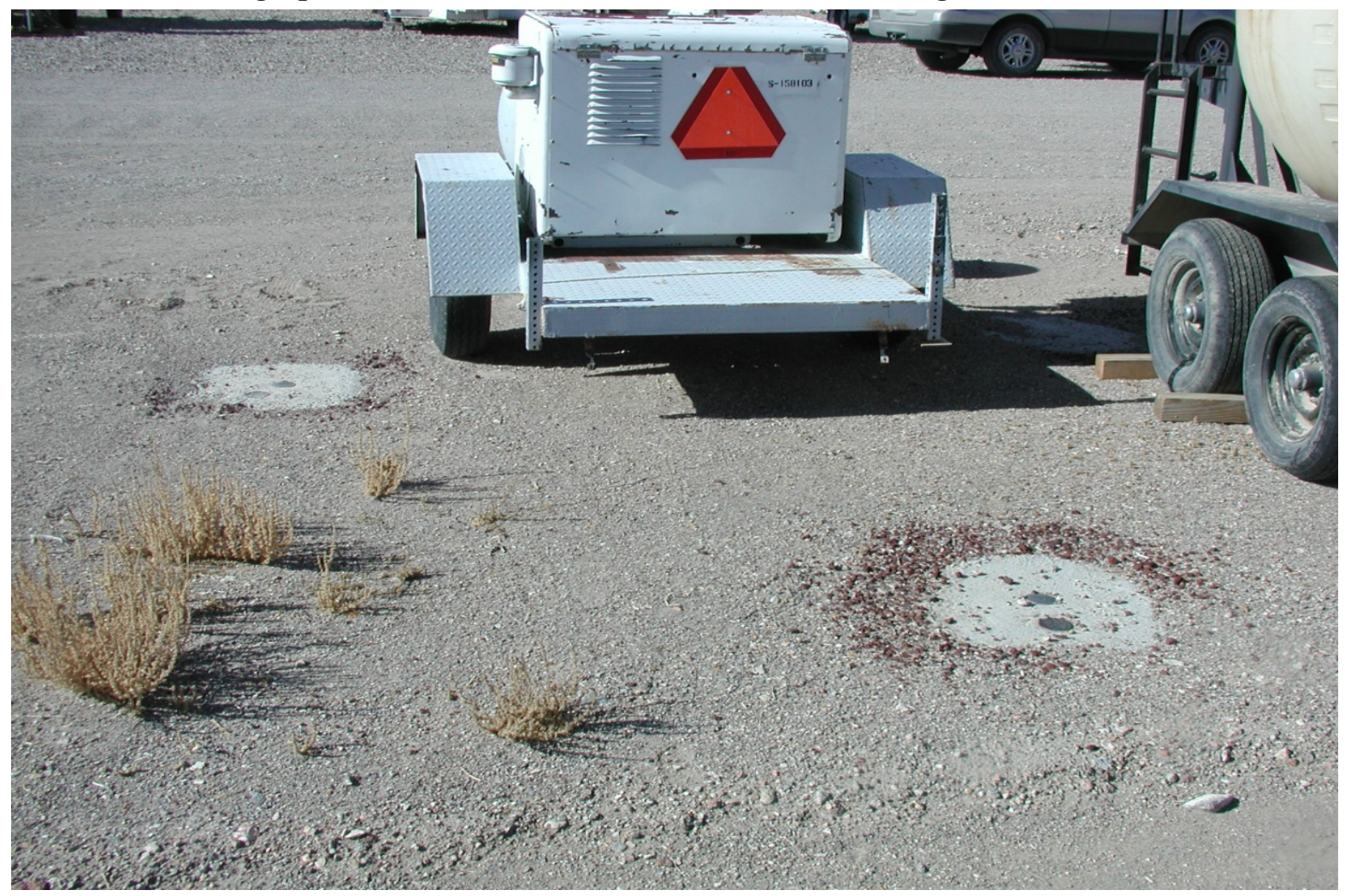

Photograph 22: CAU 424, Landfill Cell A3-3, looking west, 11/16/05 


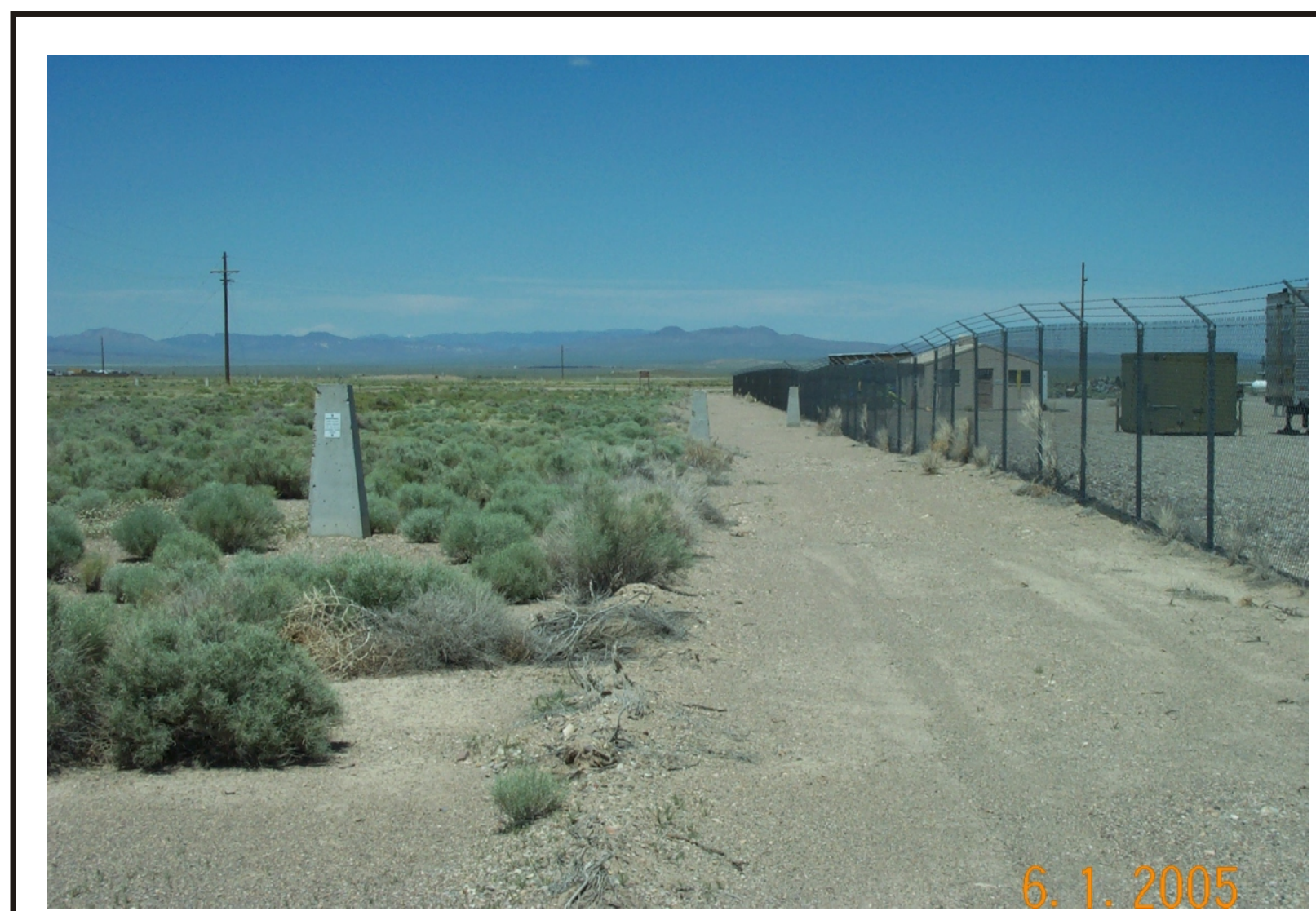

Photograph 23: CAU 424, Landfill Cell A3-3, looking north, 06/01/05

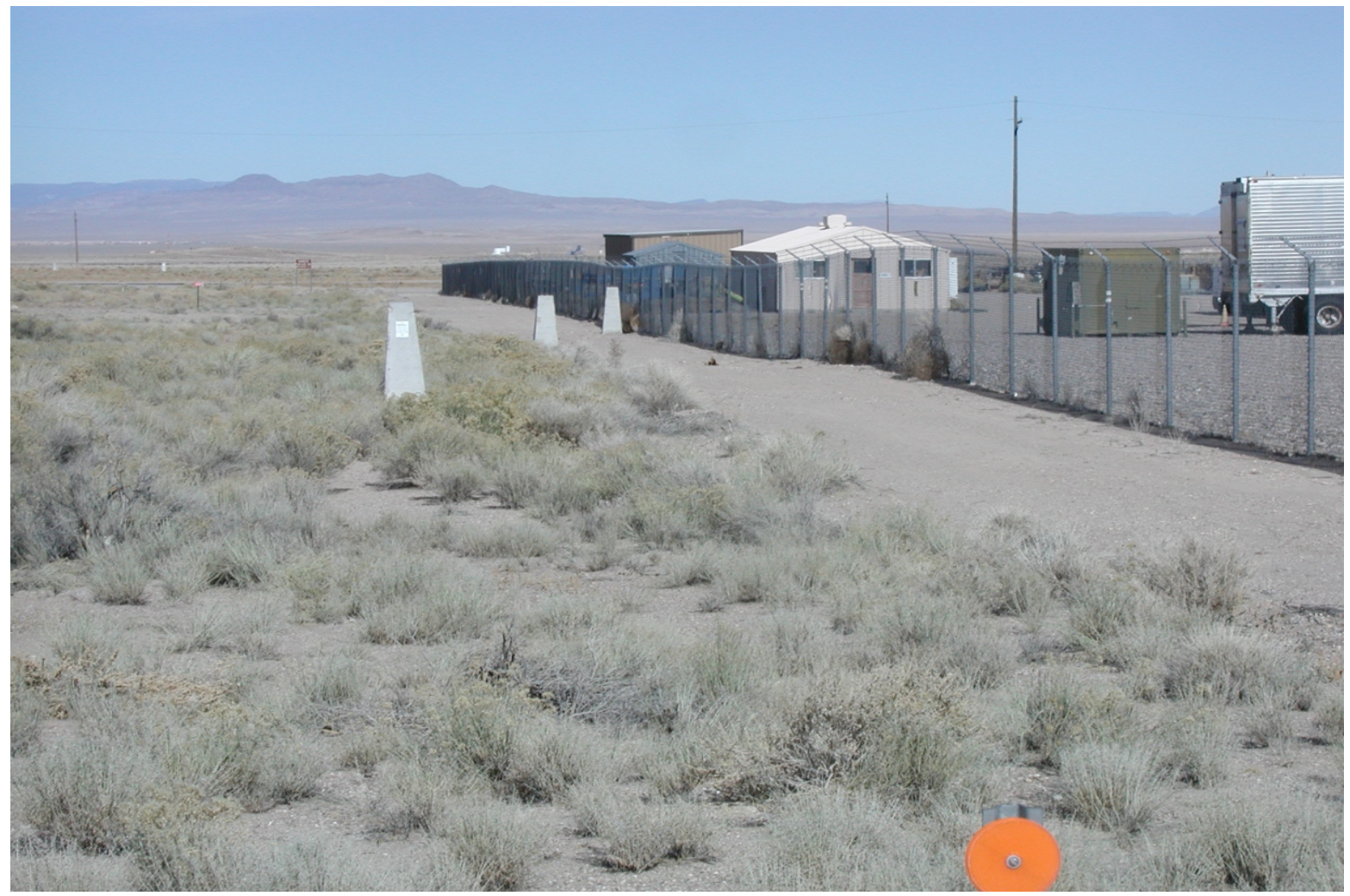

Photograph 24: CAU 424, Landfill Cell A3-3, looking north, 11/16/05 


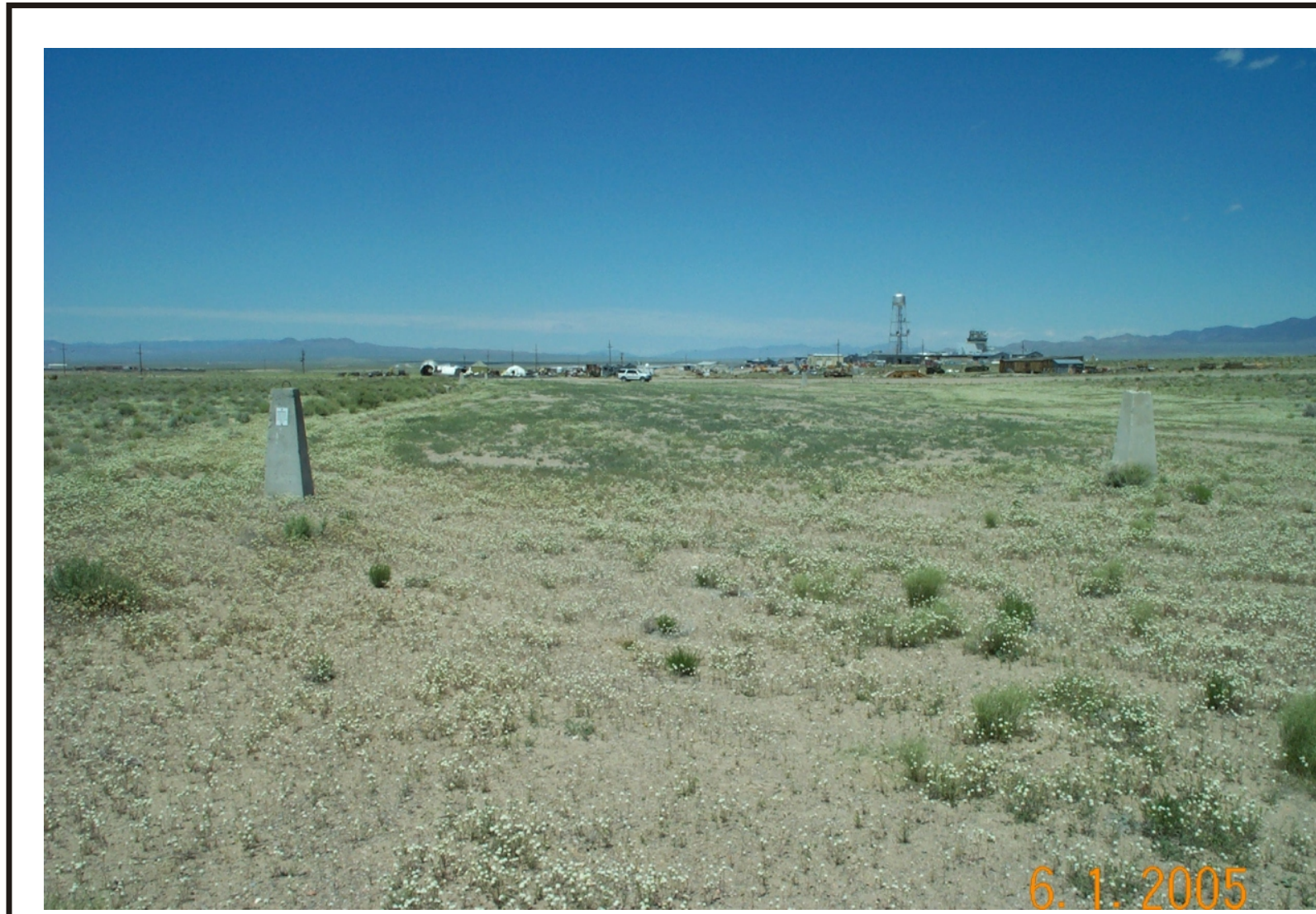

Photograph 25: CAU 424, Landfill Cell A3-4, looking north, 06/01/05

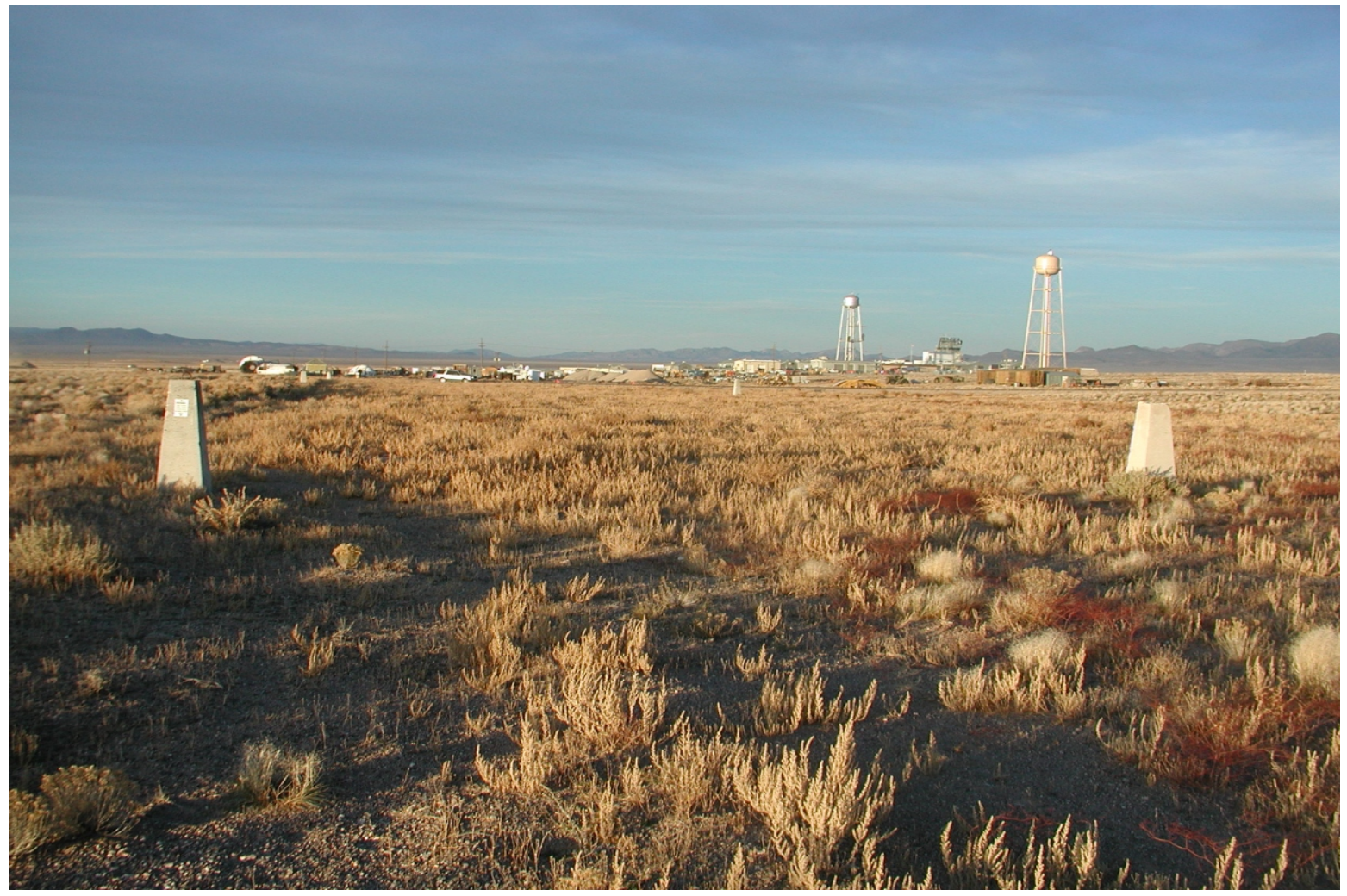

Photograph 26: CAU 424, Landfill Cell A3-4, looking north, 11/15/05 


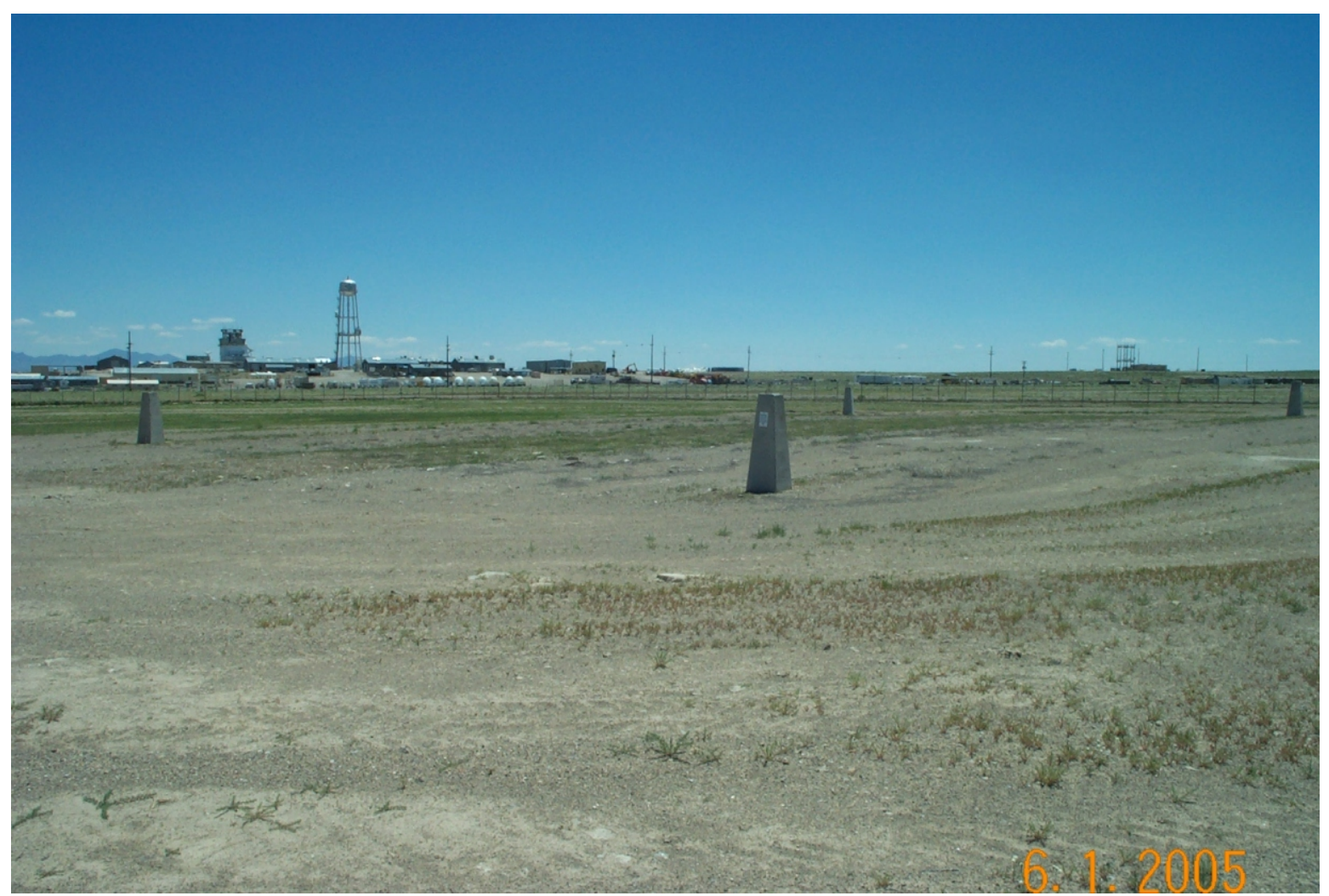

Photograph 27: CAU 424, Landfill Cell A3-5, looking southeast, 06/01/05

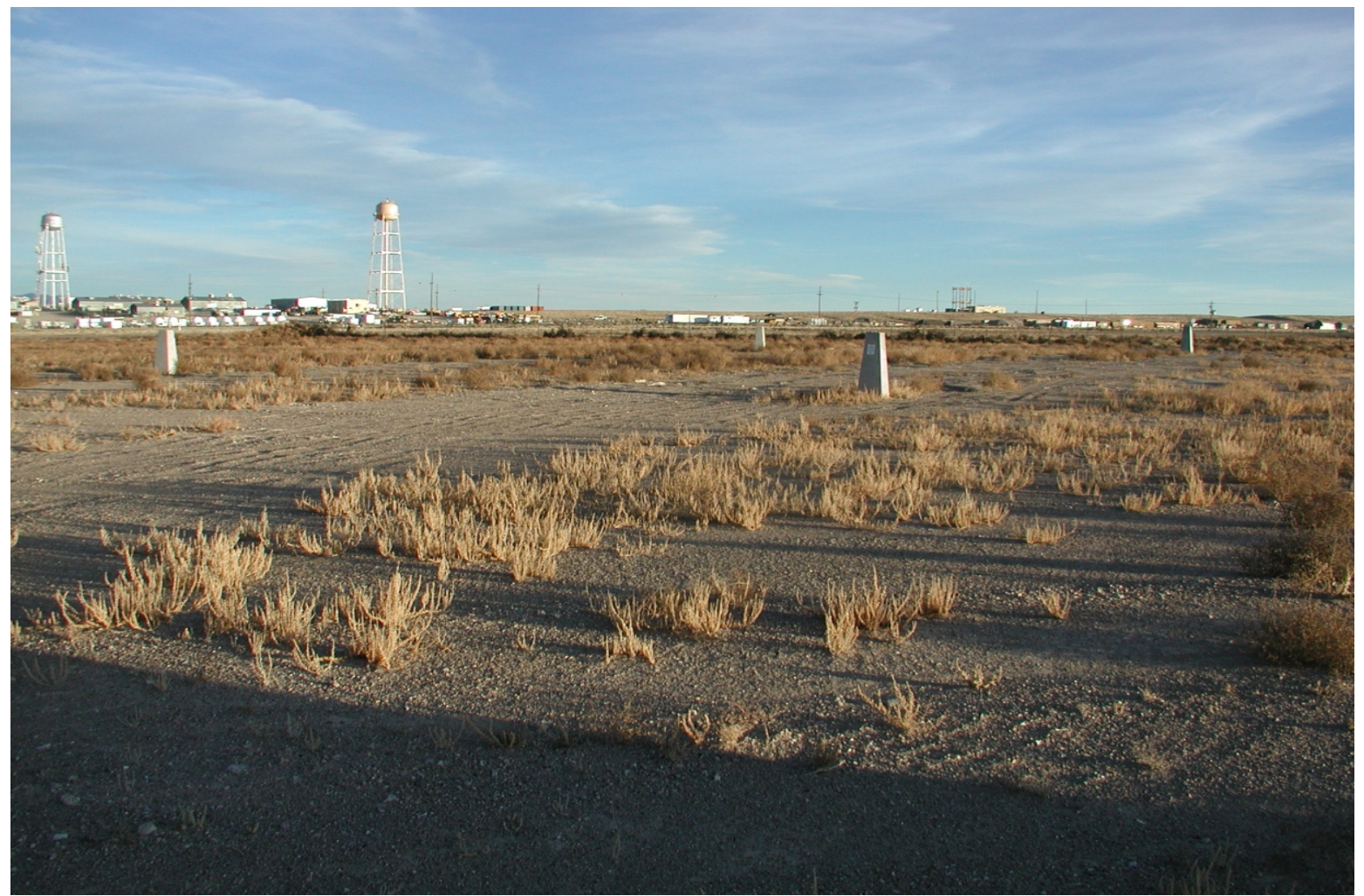

Photograph 28: CAU 424, Landfill Cell A3-5, looking southeast, 11/15/05 


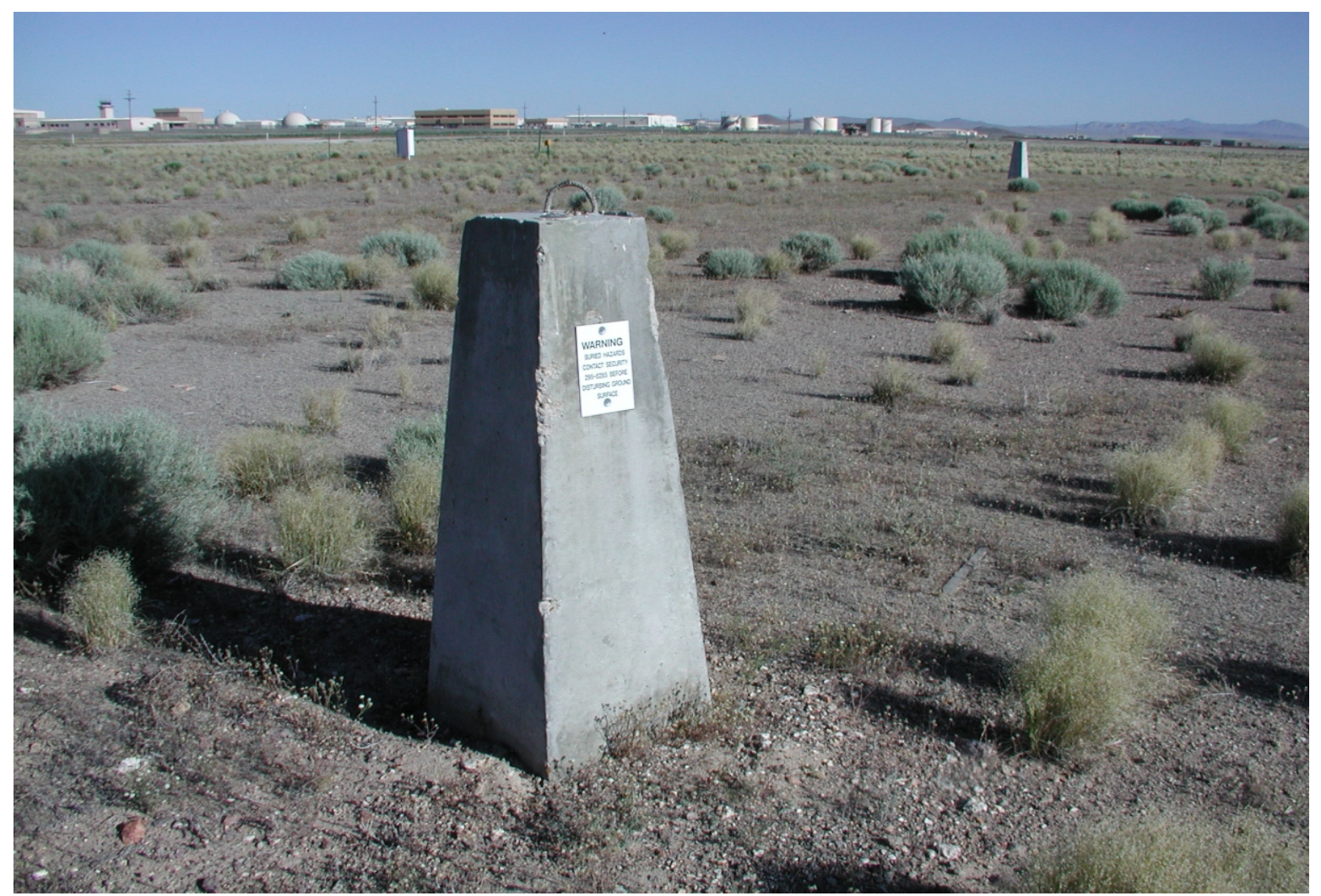

Photograph 29: CAU 424, Landfill Cell A3-6, looking northwest, 06/01/05

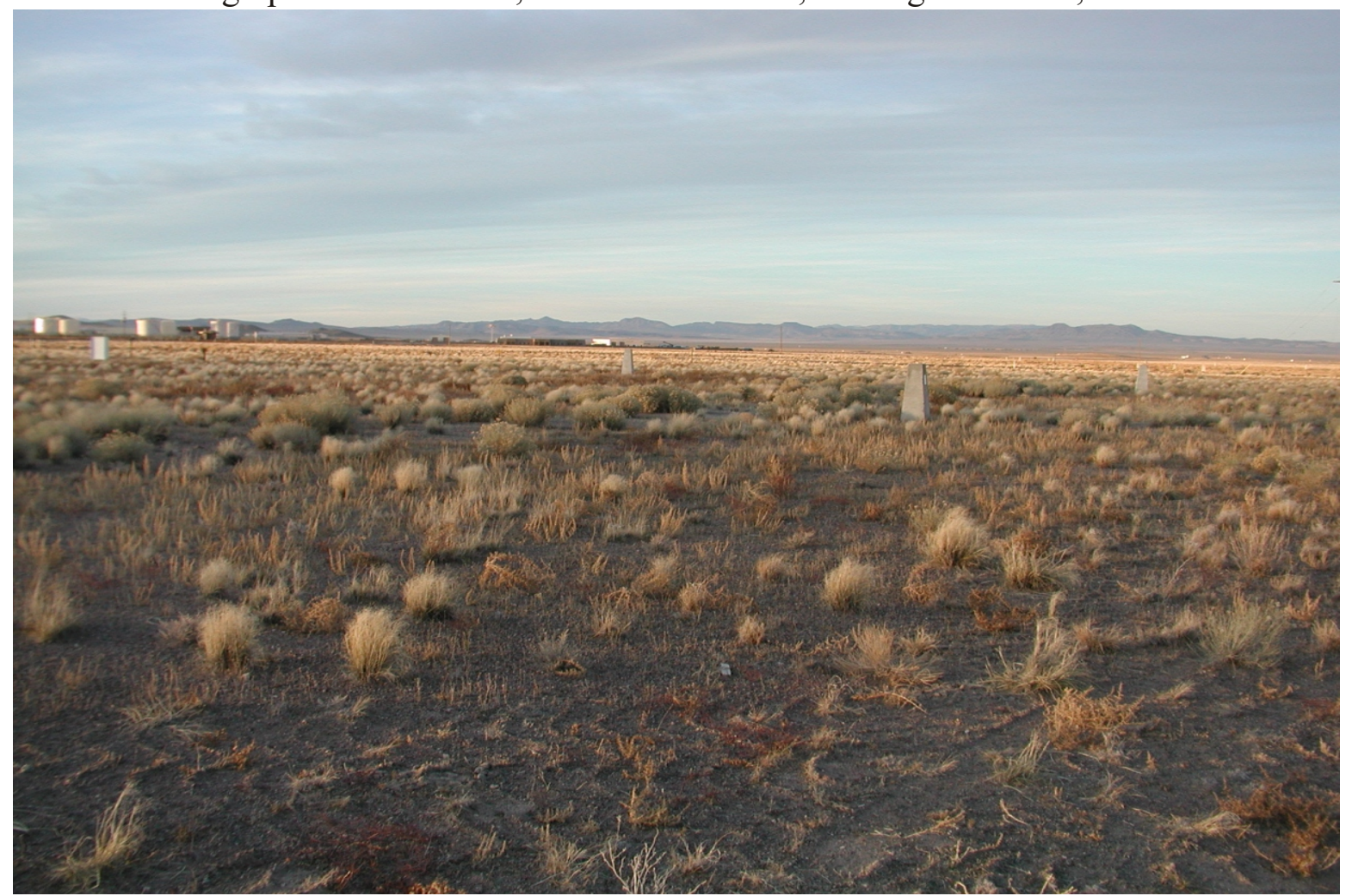

Photograph 30: CAU 424, Landfill Cell A3-6, looking northwest, 11/15/05 


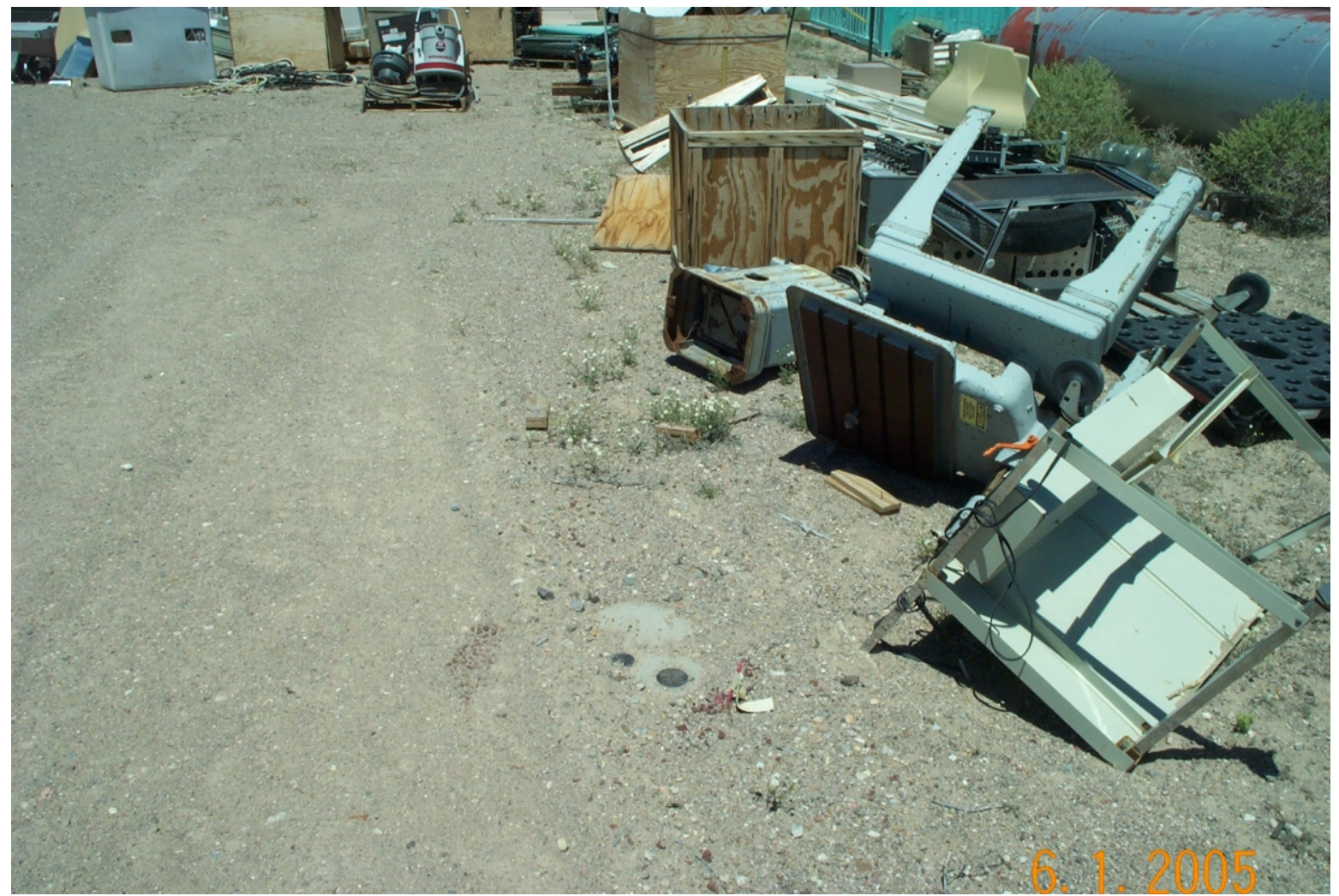

Photograph 31: CAU 424, Landfill Cell A3-8, looking north, 06/01/05

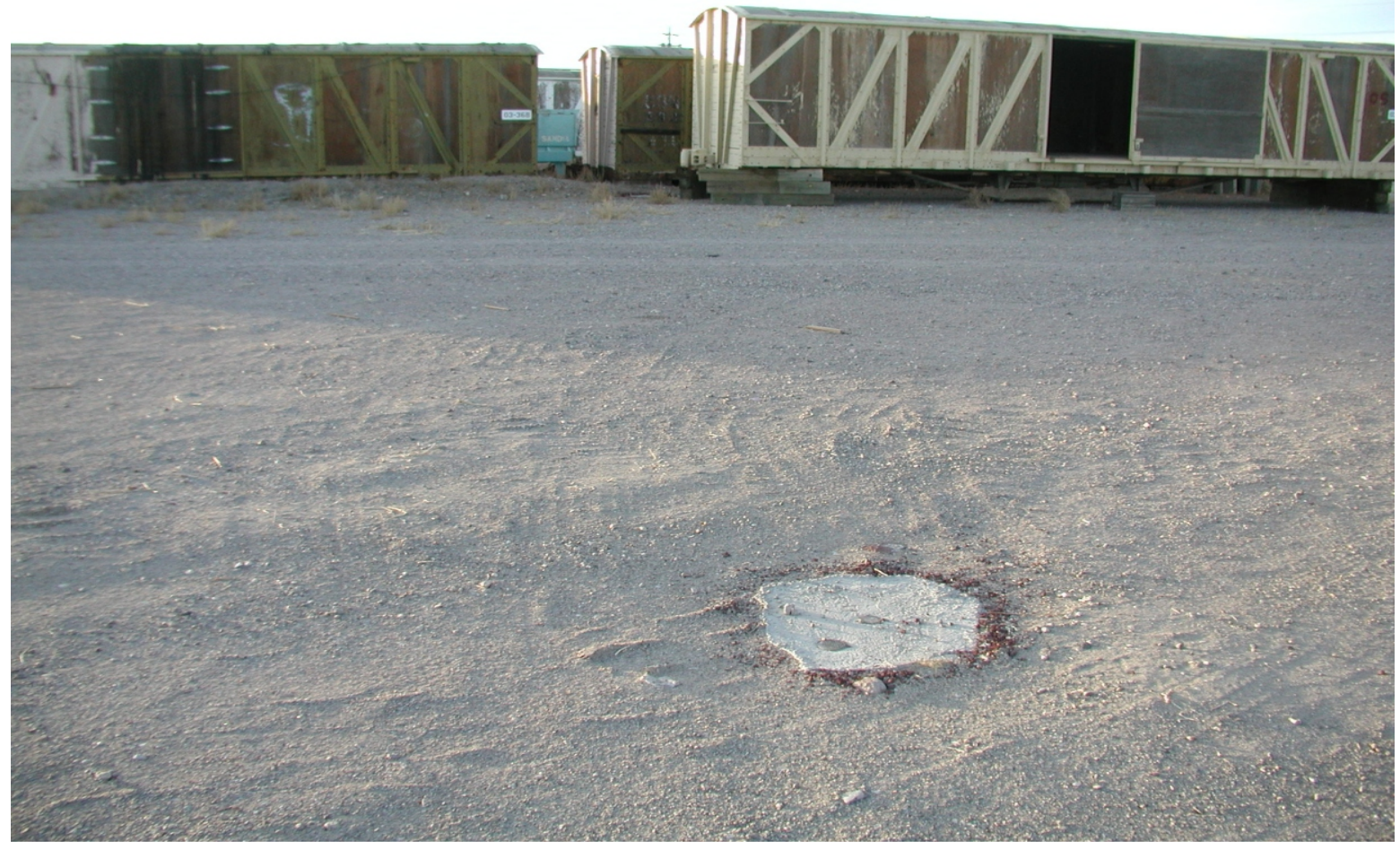

Photograph 32: CAU 424, Landfill Cell A3-8, looking west, 11/15/05 


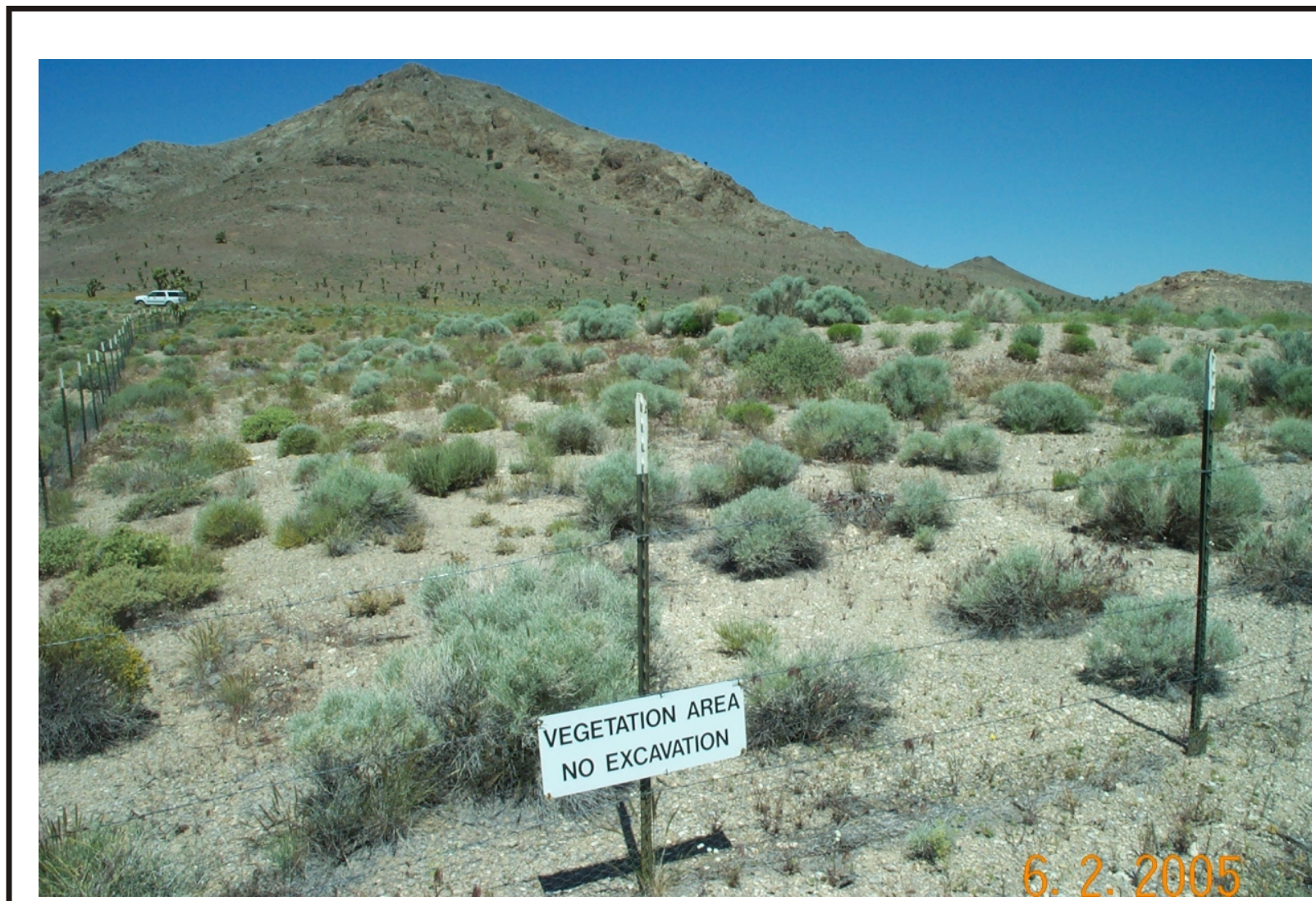

Photograph 33: CAU 426, looking north, 06/02/05

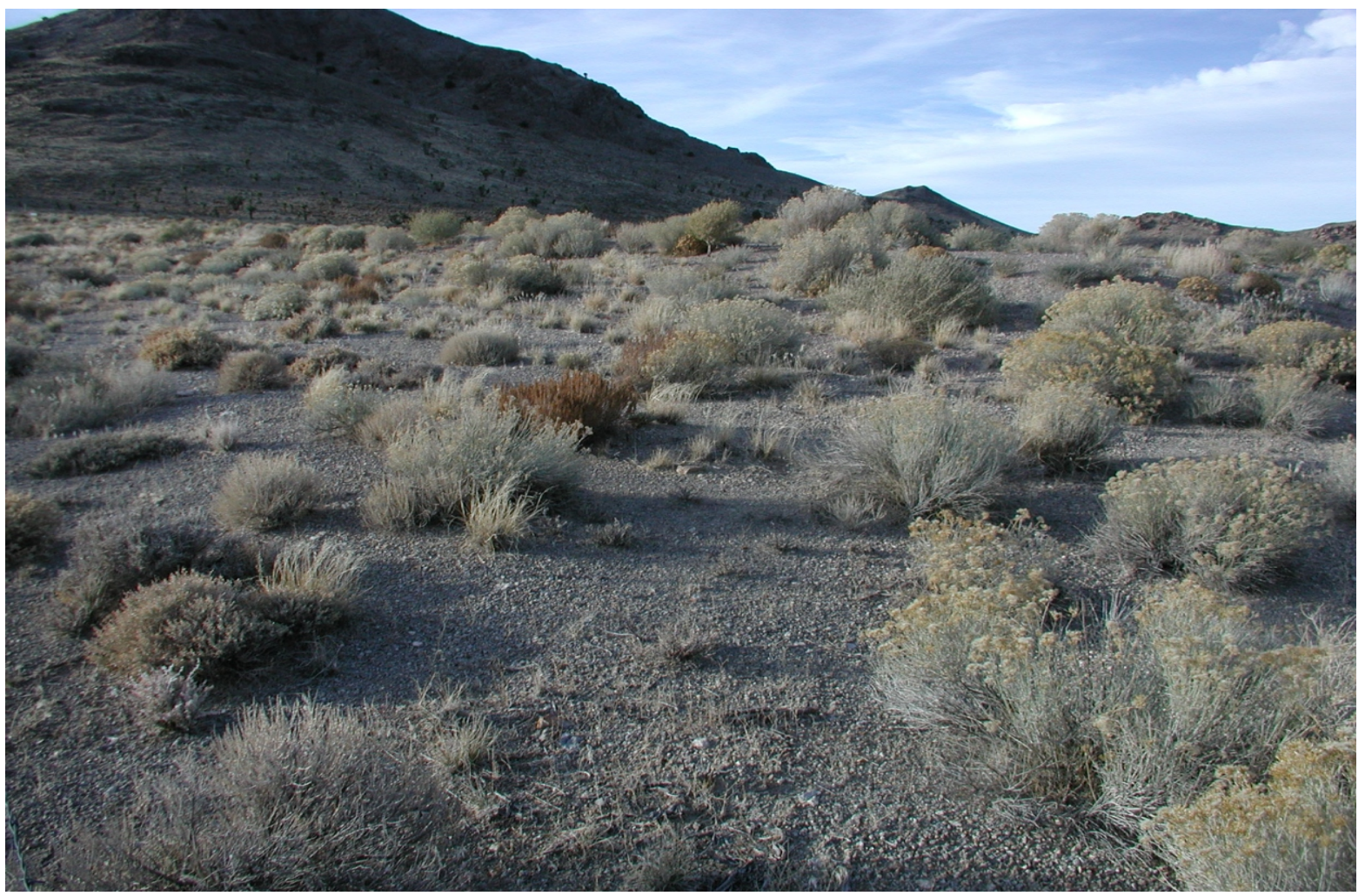

Photograph 34: CAU 426, looking north, 11/15/05 


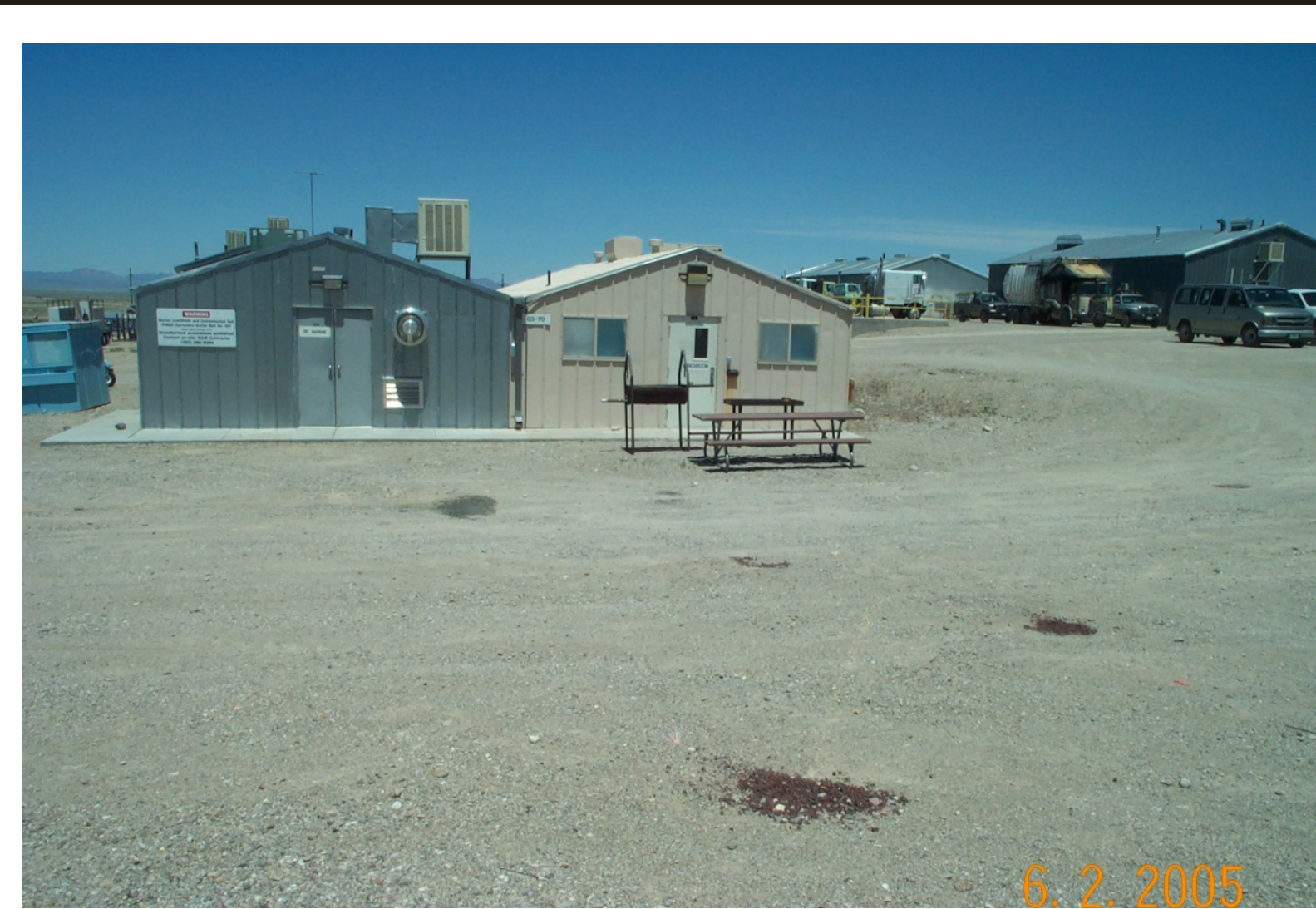

Photograph 35: CAU 427, looking north, 06/02/05

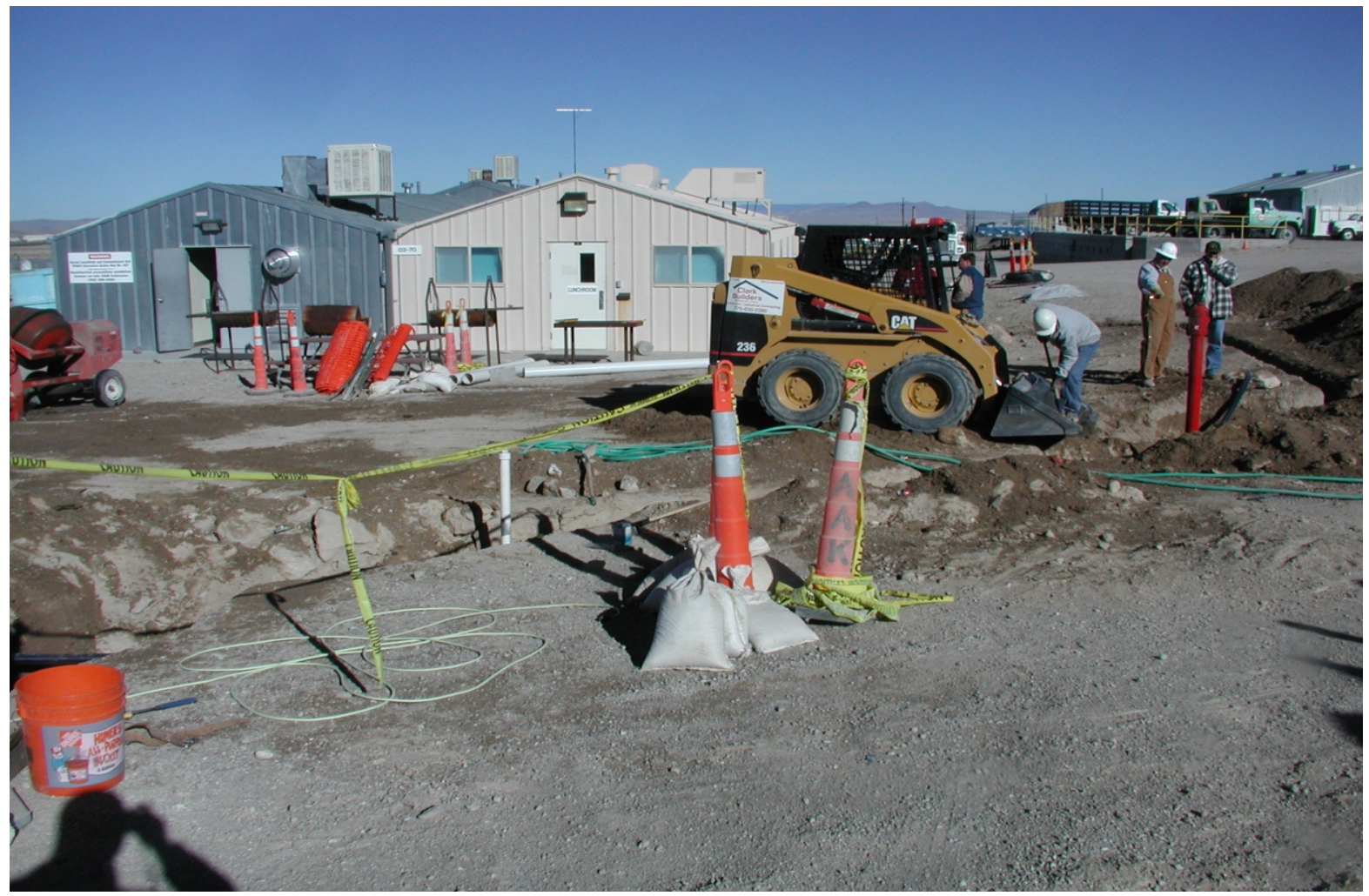

Photograph 36: CAU 427, looking north, 11/16/05 


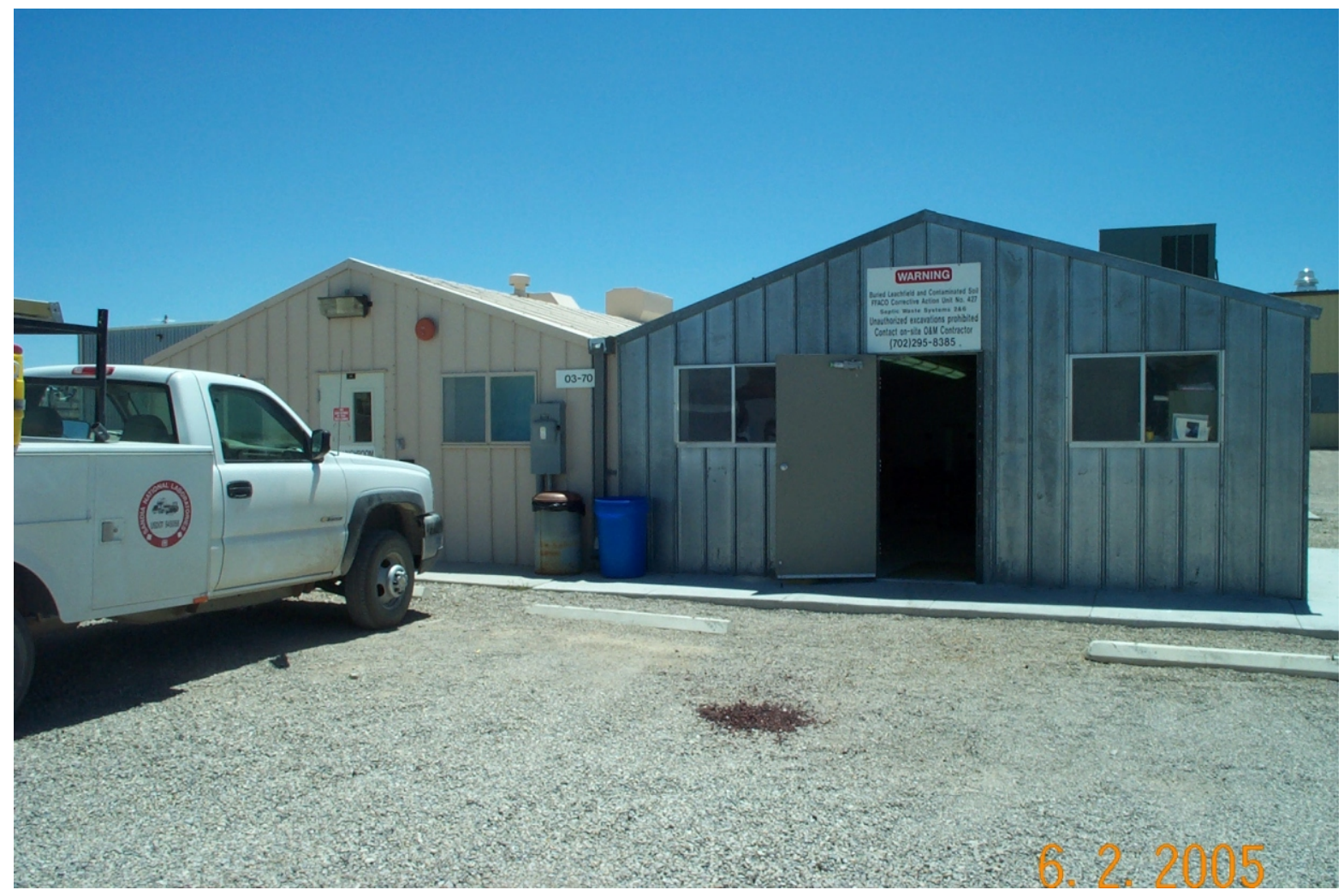

Photograph 37: CAU 427, looking south, 06/02/05

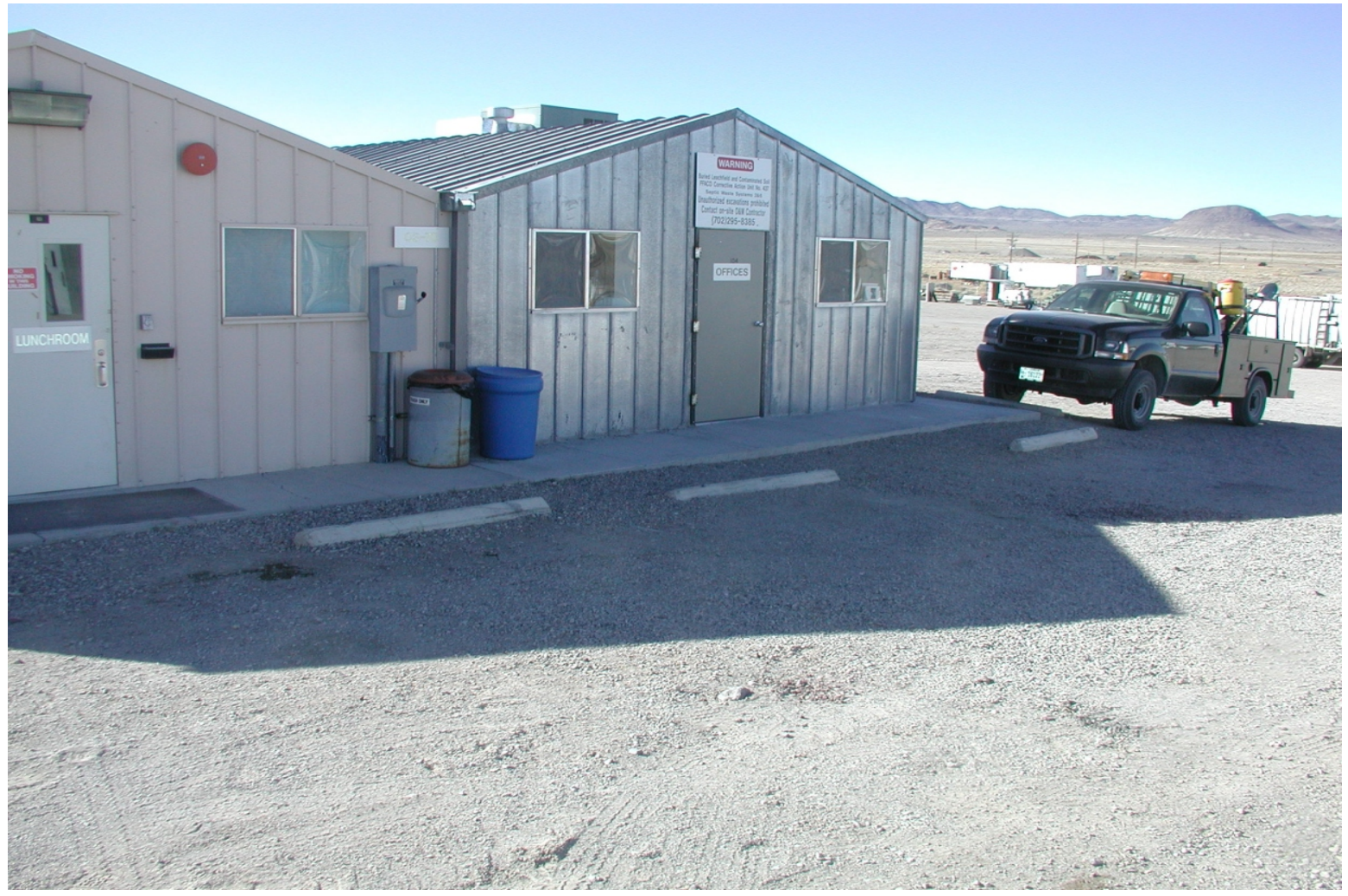

Photograph 38: CAU 427, looking south, 11/16/05 


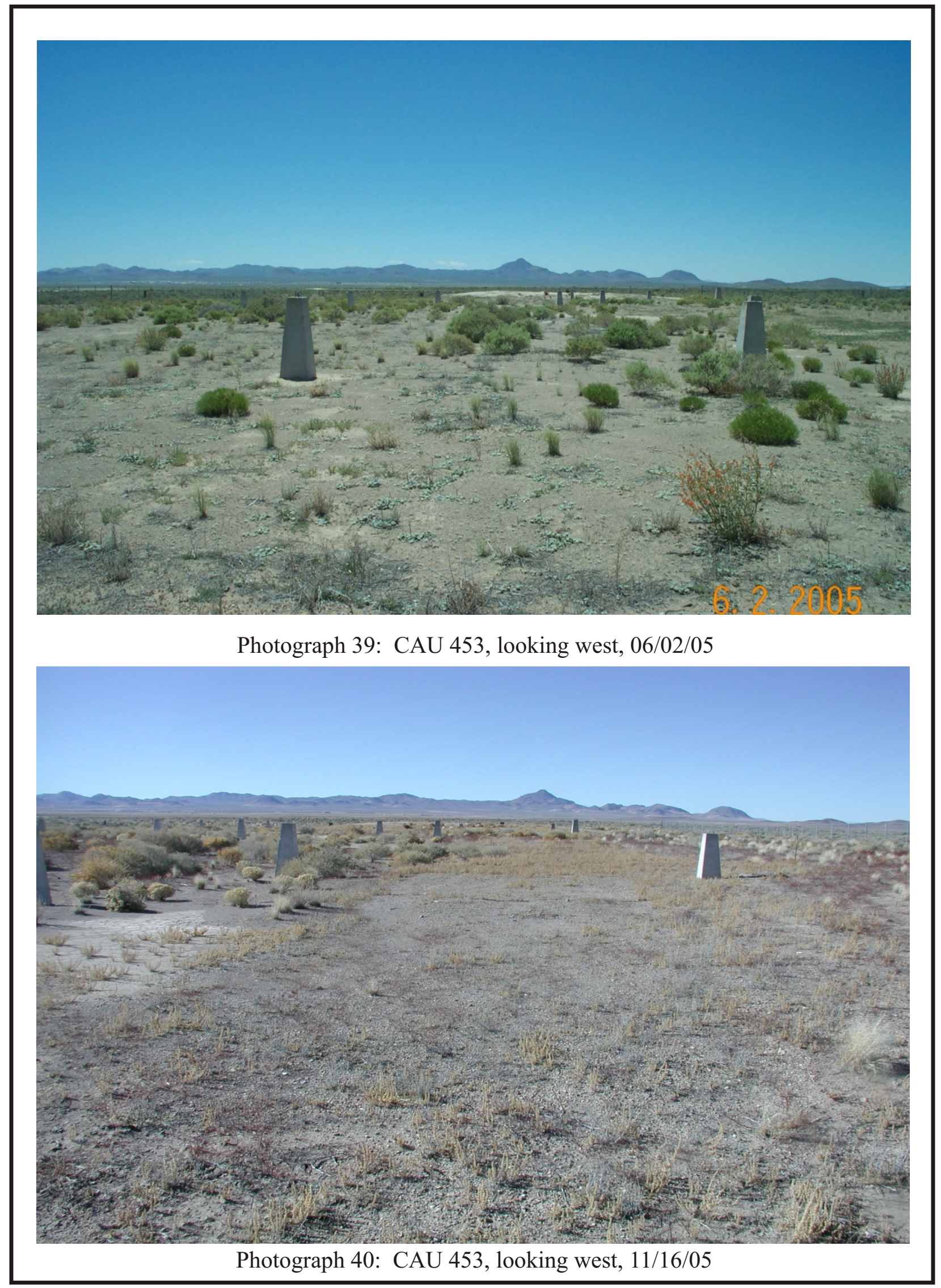




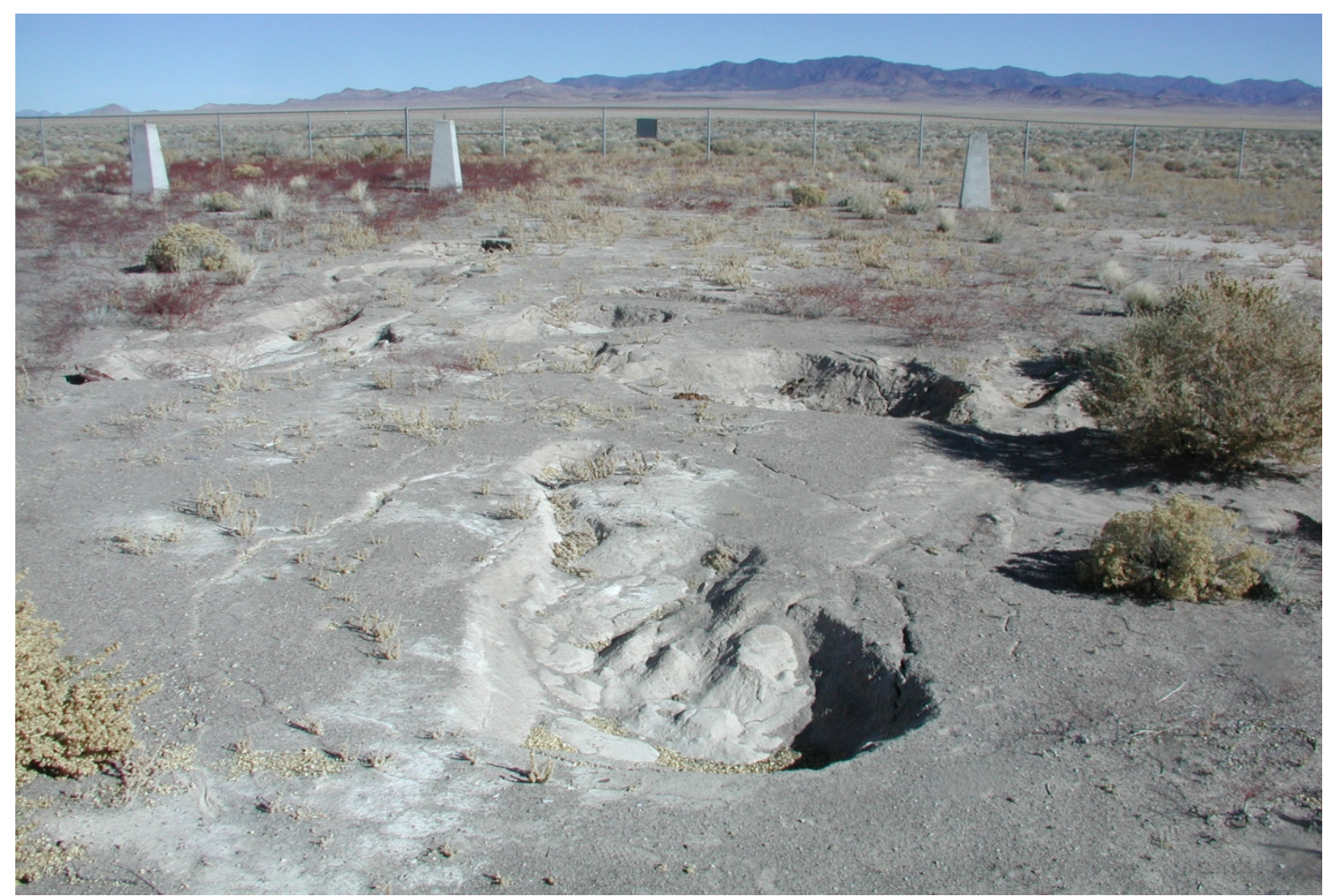

Photograph 41: CAU 453, soil subsidence, 11/16/05

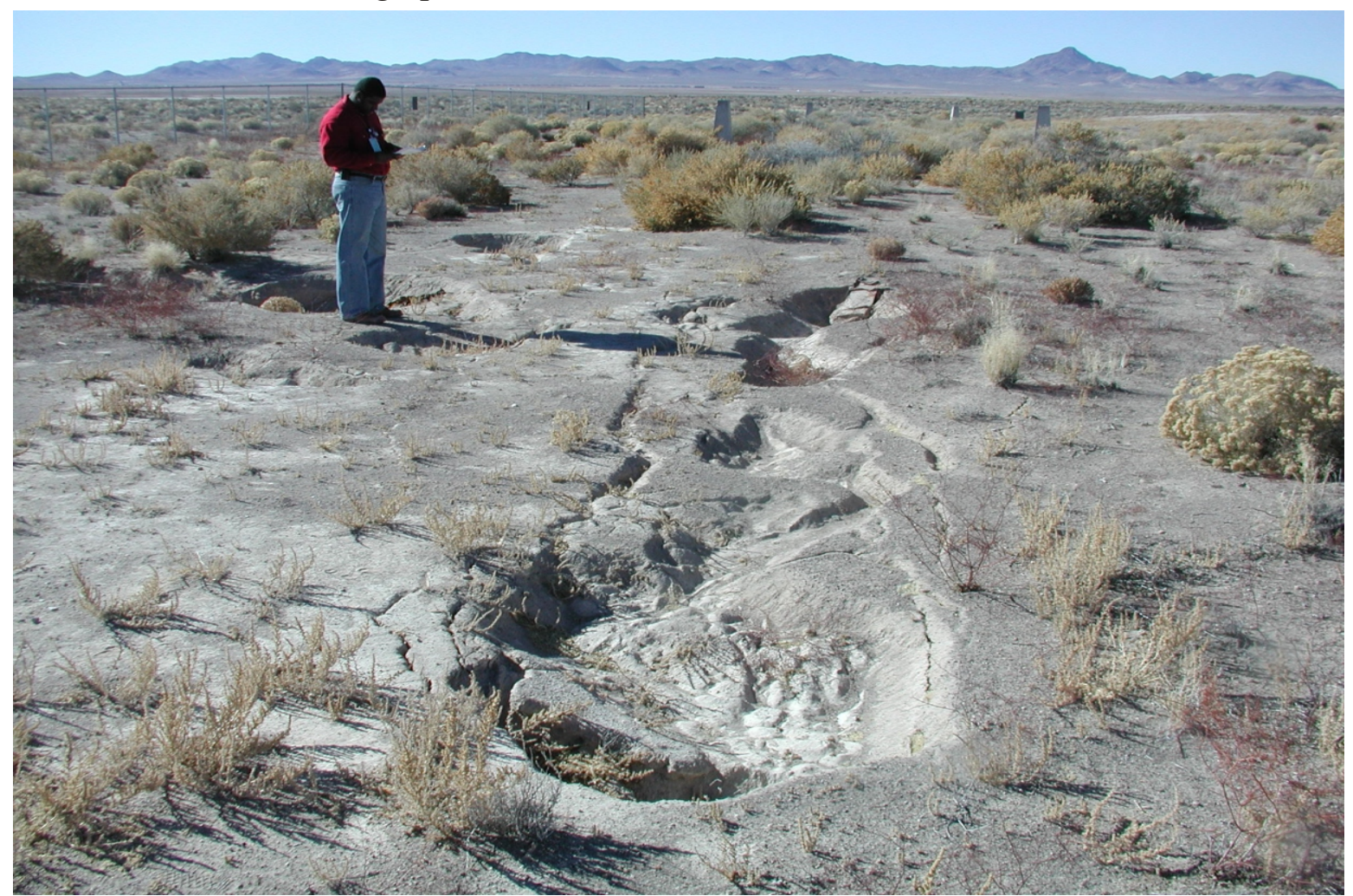

Photograph 42: CAU 453, soil subsidence, 11/16/05 


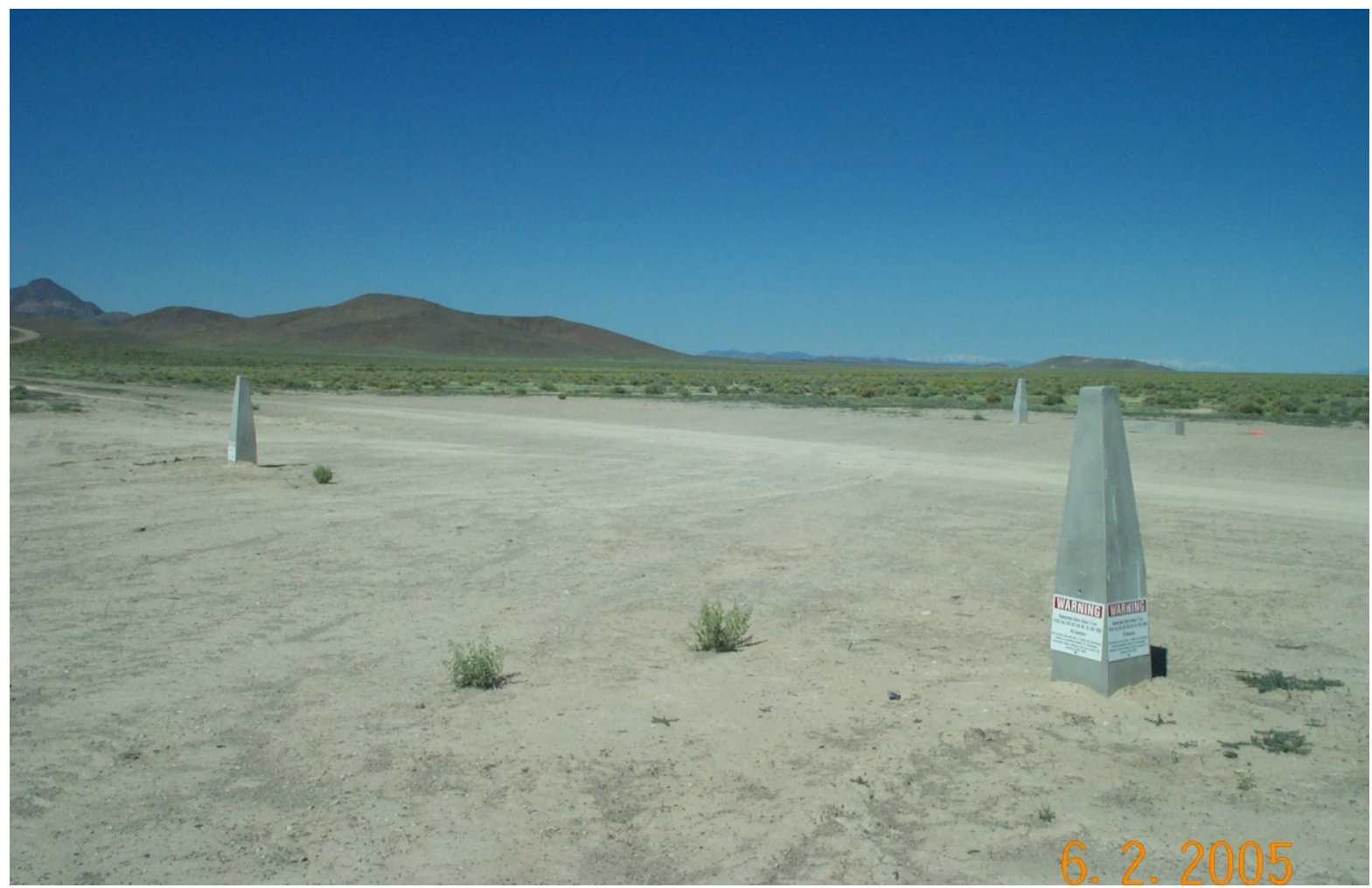

Photograph 43: CAU 487, A-8 anomaly, looking southwest 06/02/05

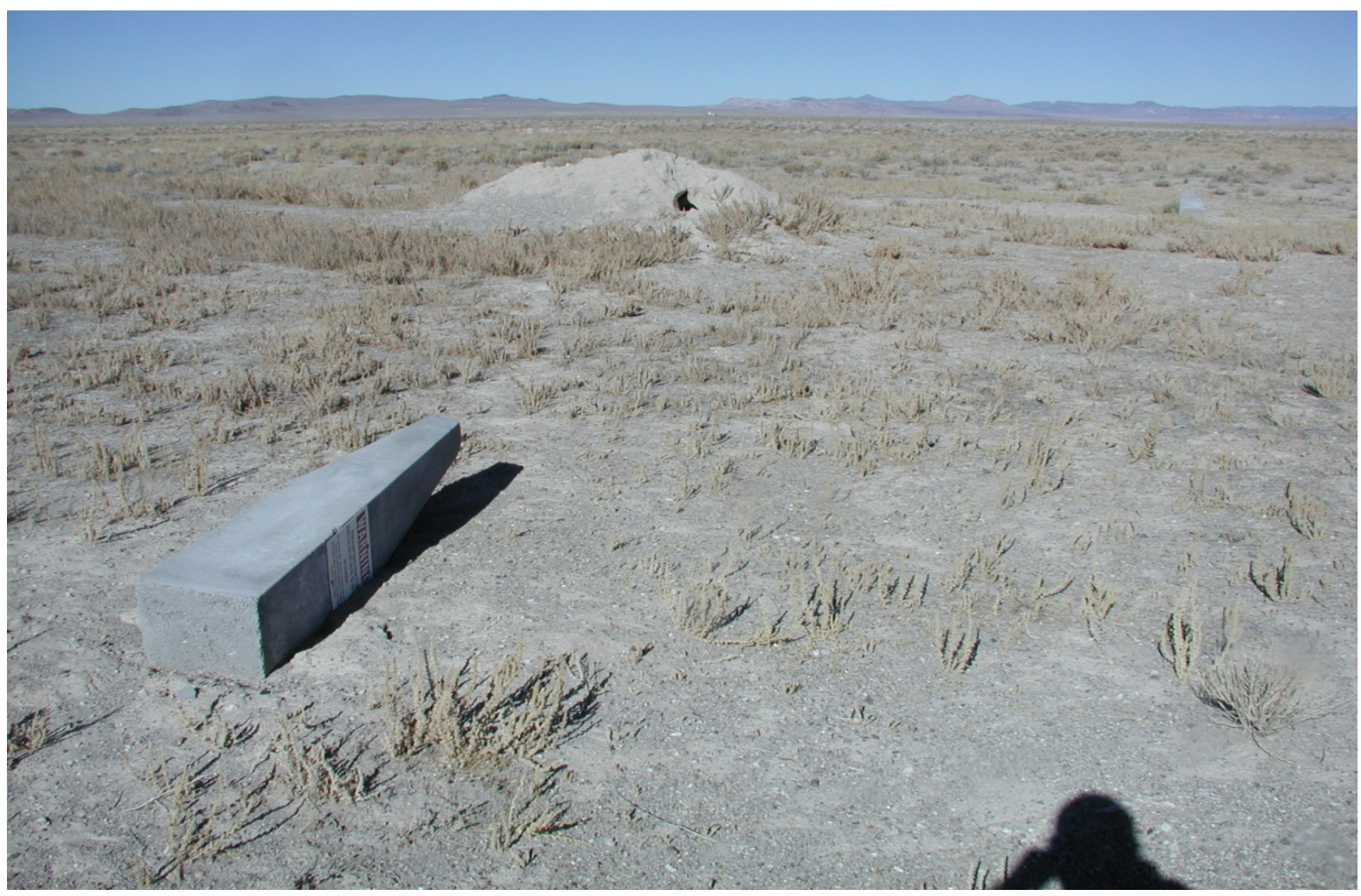

Photograph 44: CAU 487, A-17 anomaly, looking north 11/16/05 


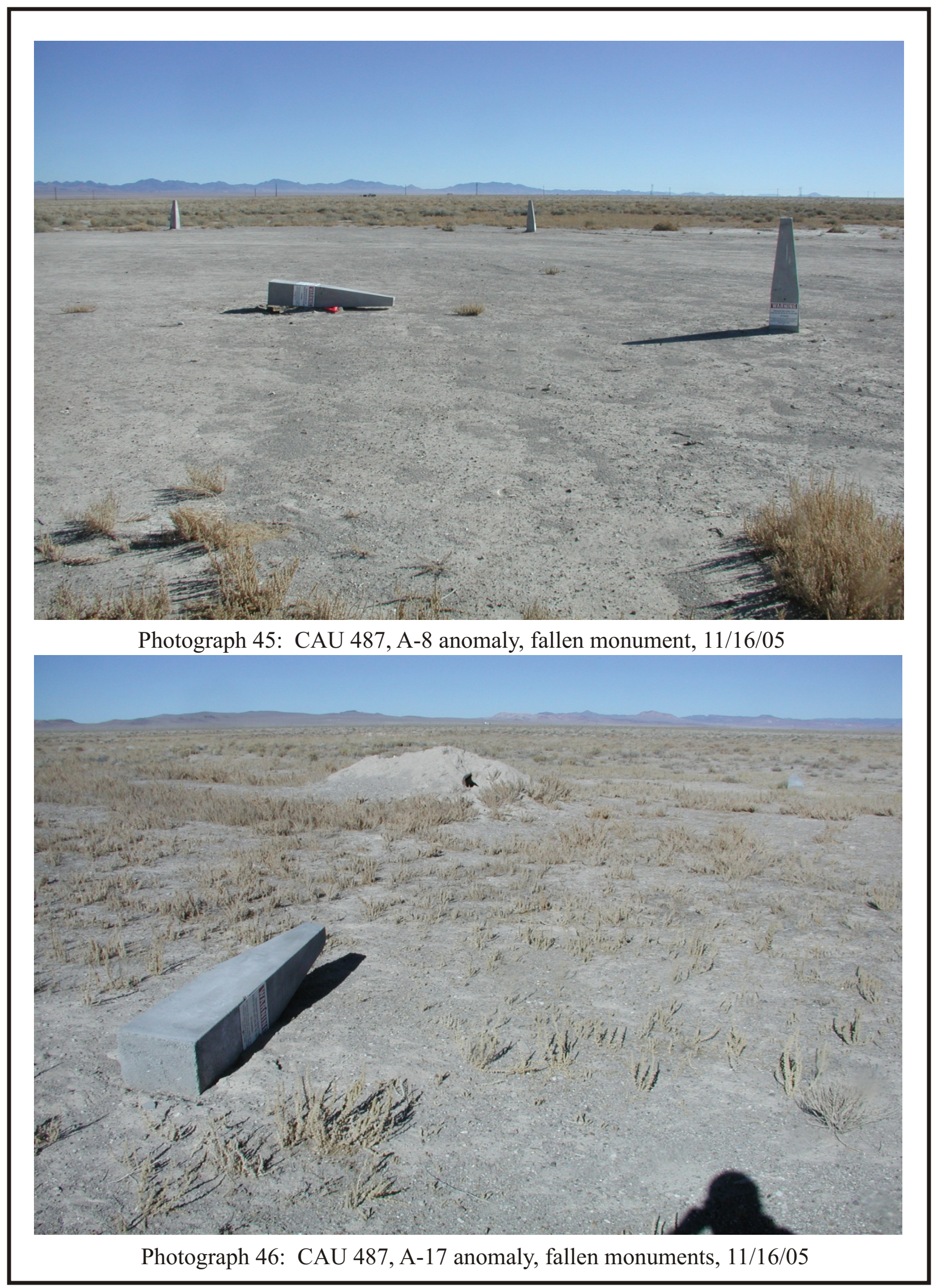


Post-Closure Inspection Report - TTR

Revision: 0

Date: June 2006

\section{AtTACHMEnT F. \\ Post-Closure Vegetation \\ MONITORING REPORT}


Post-Closure Inspection Report - TTR

Revision: 0

Date: June 2006

THIS PAGE INTENTIONALLY LEFT BLANK

F-2 


\section{POST-CLOSURE \\ VEGETATION MONITORING REPORT}

CORRECTIVE ACTION UNITS:

400-FIVE POINTS LANDFILL

400-BOMBLET PIT

404-ROLLERCOASTER SEWAGE LAGOONS

426-CACTUS SPRINGS WASTE TRENCHES

407-ROLLERCOASTER RADSAFE

Field Work Completed on

June 7 \& 8, 2005

Report prepared by

Bechtel Nevada

Ecological Services

September 2005 
Post-Closure Inspection Report - TTR Revision: 0

Date: June 2006

\section{THIS PAGE INTENTIONALLY LEFT BLANK}




\section{BACKGROUND}

Work at Corrective Action Units (CAU) 400-Five Points Landfill and Bomblet Pit, 404Rollercoaster Sewage Lagoons, and 426-Cactus Springs Waste Trenches was completed during the summer of 1997. In the fall of 1997 these four closure sites were seeded with a mix of native shrub and grass seeds. Each site was mulched with straw that was crimped into the soil. Sites were protected from grazing animals (primarily horses and rabbits) by installing a four-strand barbed-wire fence with two-foot high chicken wire fence along the base. In the fall of 2000 , the cover at CAU 407-Rollercoaster RADSAFE area was revegetated with a mix of native shrubs and grasses. The site was covered with a straw-mulch and was crimped into the soil. The site was fenced with several strands of wire with the primary purpose of preventing inadvertent human entry to the site and preventing horses from accessing the site.

Remedial revegetation efforts have occurred at two of the original sites. A flash flood swept through the center of the CAU 400-Five Points Landfill site in the summer of 2003. The perimeter fence along the northeastern edge of the site was damaged and many plants in the path of the flood waters were submerged or coated with a thin layer of mud. Many of the plants died leaving large areas without vegetation. The damaged fence was repaired and the site was seeded in the fall of 2004. Native plant species (Table 1) were seeded at a rate of 39.6 pounds per acre (lbs/ac) of pure live seed (PLS). Site preparation included the removal of dead vegetation and pulling a drag chain over the site to roughen the soil surface. The site was seeded using a broadcast seeder mounted on the front of an all terrain vehicle (ATV) (Figure 1). Drag chains were pulled behind the seeder to cover the seed (Figure 1).

Table 1. Seed mix used for remedial revegetation CAU 400Five Points Landfill.

$\begin{array}{llc} & \text { Common Name } & \text { PLS (lbs/ac) } \\ \text { Shrubs } & \text { Basin Big Sagebrush } & 0.8 \\ & \text { Fourwing Saltbush } & 1.7 \\ & \text { White burrobrush } & 4.5 \\ & \text { Winterfat } & 4.5 \\ \text { Grasses } & \text { Indian Ricegrass } & \\ & \text { Squirreltail } & 3.3 \\ & \text { Galleta } & 1.8 \\ \text { Totals } & & \underline{2.0}\end{array}$

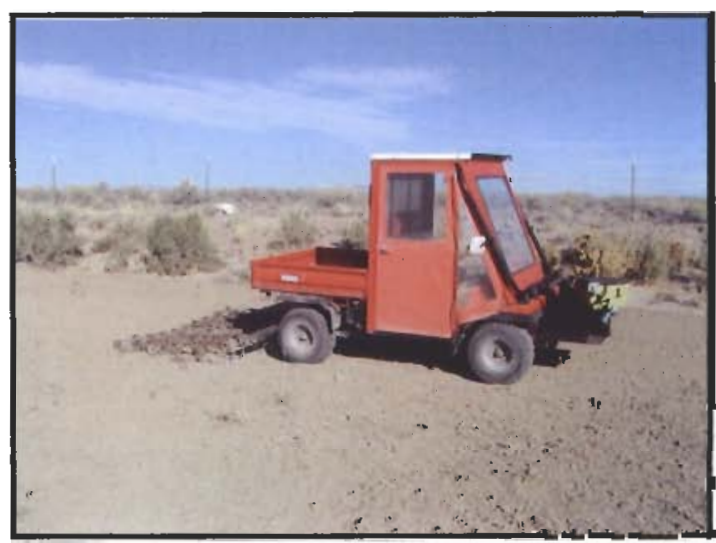

Figure 1. Kawasaki mule, equipped with a frontmounted broadcast seeder and drag chain, was used to prepare and seed the site. 
CAU 407-Rollercoaster RADSAFE area was disturbed during the construction of erosion control measures after it was originally seeded in the fall of 2000. The construction activities resulted in the removal of all the vegetation on the surface of the cover cap. Over the past four years the soils on the cover cap had become compacted and erosion was occurring along the edges. In the fall of 2004 repair work was made to the erosion channels along the edges of the cover cap. Soil was hauled to the site and erosion channels were filled. The soil cover was then ripped (by a grader equipped with ripper teeth) to a depth of approximately 6 inches (in) to alleviate soil compaction. The site was seeded with a mix of native plant species at a rate of 22.2 PLS lbs/ac (Table 2) using the same equipment and process used for remedial work at the Five Points Landfill. After the site was seeded a straw mulch netting (Figure 2) was installed to protect the site from erosion. Supplemental irrigation was used at the site starting in February 2005 (Figure 3 ) and continuing through June. Supplemental irrigation was used at this site to ensure there would be sufficient soil moisture for seed germination and plant establishment. Establishment of a vegetative cover was necessary to prevent erosion along the edges of the cover cap. Approximately 3.75 in of supplemental precipitation was applied during irrigation events in December (1.0”), February (0.5”), March (1.0”), May (0.75”) and June (0.5”).

Table 2. Seed mix used for CAU 407-Rollercoaster RADSAFE area.

\begin{tabular}{llc} 
& Common Name & PLS lbs/acre \\
\cline { 2 - 3 } Shrubs & Budsagebrush & 0.2 \\
& Fourwing Saltbush & 2.6 \\
& Shadscale & 6.0 \\
& Winterfat & 7.0 \\
Grasses & Indian Ricegrass & 2.0 \\
& Squirreltail & 2.0 \\
& Galleta & 2.0 \\
Forbs & Desert globemallow & $\underline{0.4}$ \\
& & 22.2
\end{tabular}

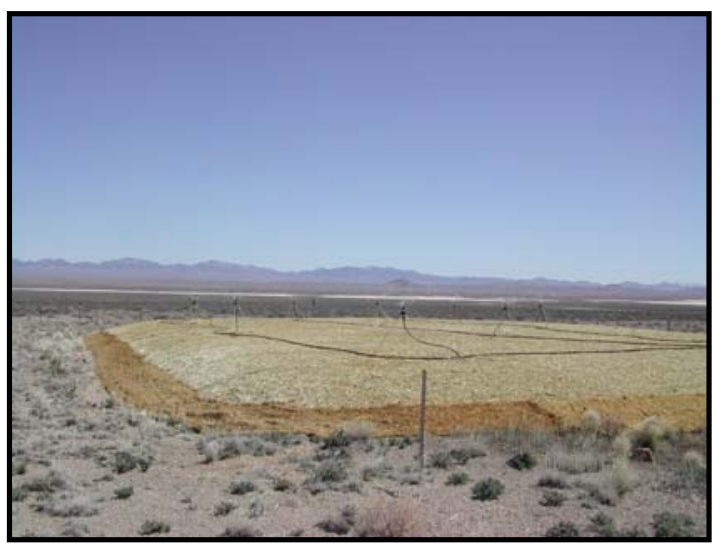

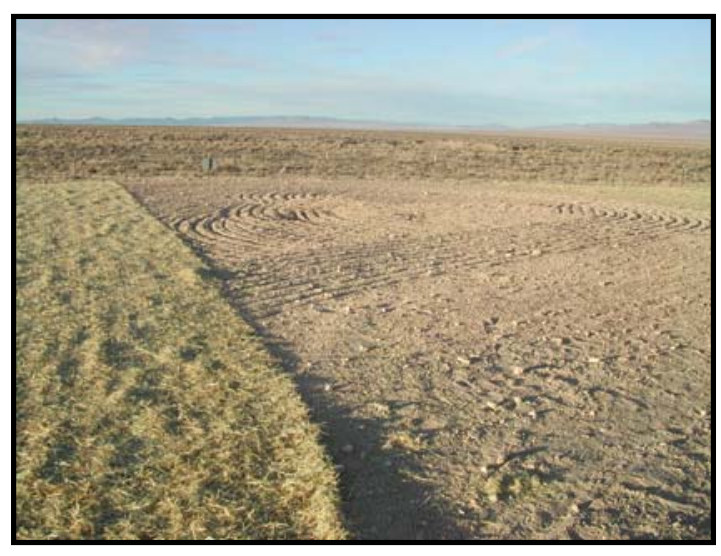

Figure 2. Installation of straw netting at the CAU 407 RADSAFE area.
Figure 3. Irrigation system consisting of 15 sprinkler heads was used to apply approximately 3.75 inches of supplemental irrigation. 
Post-Closure Inspection Report - TTR

Revision: 0

Date: June 2006

Site monitoring began the year after revegetation occurred at the site. Monitoring the first year is designed to determine if germination of seeded-plant species had occurred and included plant density estimates and photographic documentation. Monitoring in subsequent years evaluated plant establishment, evaluated long-term vegetation survival, and compared plant cover and density with adjacent reference areas (undisturbed sites). This report documents the methodology and results of monitoring efforts conducted in June 2005 at CAU 400-Five Points Landfill, CAU 400-Bomblet Pit, CAU 404 Rollercoaster Lagoons, CAU 407-Rollercoaster RADSAFE and CAU 426 Cactus Springs waste trenches, all located on the Tonopah Test Range in central Nevada.

\section{MONITORING METHODS}

BN Ecological Services staff scientists inspected the closure sites on June 7 and 8, 2005. Plant cover and density estimates were made, wildlife usage was noted, and soil erosion conditions were determined. Plant cover was estimated using an optical point projection device or cover scope. Cover sample points are taken at given intervals along a permanent placed linear transect. Plant density was estimated using one meter square quadrats, also placed at given intervals along each transect. The total number of individual plants located within the boundaries of the quadrat was recorded. The data were averaged over all quadrats to obtain average plant densities, i.e. plants per square meter $\left(/ \mathrm{m}^{2}\right)$. Wildlife usage of the site was determined by noting any wildlife or wildlife sign i.e. burrows, observed during sampling. The erosion condition of the soil over the site in general was determined using a modified Bureau of Land Management erosion condition classification (Appendix F.3). Reference areas were similarly sampled and cover and density estimates serve as a standard to evaluate revegetation success.

\section{MONITORING RESULTS}

\section{A. CAU 400-FIVE POINTS LANDFILL}

Overall plant density decreased by about 23\% from 2004 to 2005. There actually was a slight increase in shrub density (Table 3) but the density of grasses continues its decline, showing an almost 70\% decrease from densities reported in 2004. The density of both Indian ricegrass and squirreltail grass declined. Indian ricegrass has shown a gradual annual decline since 2000 (Table 3).

Plant cover decreased by a little over 10\% (Table 3) and represents the lowest amount of plant cover at this site since it cover data was taken in 2000. The decline is a direct result of the flooding that occurred at the site in 2003. Plants are either recovering from the effects of the flash flood or new seedling are just becoming established and do not contribute much to overall plant cover.

Wildlife use of the site has been evident the first few years after revegetation was completed. Several small mammal burrows are located throughout the site but are most abundant in the southeastern section of the site. Occasional rabbit scat was observed but there is no indication that the shrubs are being detrimentally browsed by rabbits. 
Post-Closure Inspection Report - TTR Revision: 0

Date: June 2006

There was no evidence of an erosion problem up until 2003. A flash flood entered the area from the east via a natural drainage channel as a result of a summer thunderstorm. The rushing waters removed much of the vegetation along the eastern edge of the drainage then ponded in the depression of the western end of the closure site. Vegetation was inundated with water for an extended period of time resulting in the death of the existing vegetation. Receding waters left many plants on the periphery of the standing water covered with a thick coat of mud, which in many cases resulted in plant mortality. No additional erosion damage was observed on site since remedial work was completed last fall.

Table 3. Plant density and cover on CAU 400-Five Points Landfill

Plant Density (\# Plants $/ \mathbf{m}^{2}$ )

Shrubs Bud sagebrush

Fourwing saltbush

Greene's rabbitbrush

Winterfat

Total shrubs

Grasses Squirreltail

Galleta

Indian ricegrass

Total grasses

Total Perennials

Total Annuals $\underline{\text { May-00 }}$

0.0

0.7

$\underline{0.0}$

0.7

2.2

0.6

$\underline{4.8}$

7.1

7.7

10.2

May-00

2.5

$\underline{10.0}$

12.5

3.3

66.6

17.5
Shrub

Grass

Perennial Plant Cover

Annuals (not seeded)

Bare Ground/Rock

Litter/Mulch

\section{Jun-02}

Small

burrows

Stable

Erosion Classification

* Density of Annuals not recorded for reference site in 2005

Wildlife

8.3

$\underline{22.5}$

30.8

1.7

50.0

17.5

\section{Sept-}

9.2

10.0

19.2

0.0

57.5

23.3

Small mammal

burrows

Stable

Critical

\section{June-0}

0.0

1.1

$\underline{0.03}$

1.1

\section{4}

0.1

$\underline{1.0}$

1.6

2.6

1.9

0.0

$\underline{0.4}$

0.5

$13.5 \quad 56.4$ $\underline{\text { Ref } 05}$

0.0

0.1

0.5

$\underline{0.0}$

0.6

0.0

0.03

$\underline{1.1}$

1.2

1.8

1.8

Ref 05

8.1

$\underline{3.1}$

11.3

10.0

66.2

12.5

$11.5 \quad 12.5$


Post-Closure Inspection Report - TTR Revision: 0

Date: June 2006

B. CAU 400-BOMBLET PIT

Plant density at CAU 400-Bomblet Pit this year was 8\% lower than it was in 2004 (Table 4). There are still just three shrubs (bud sagebrush, fourwing saltbush and shadscale) found on the site. The density of bud sagebrush was about the same as it was last year, however, no fourwing saltbush was encountered but a few winterfat plants were found. The density of shadscale decreased by 13\% from 2004 to 2005. As in 2004 no grasses were encountered. The density of annual plants, taking advantage of an abundance of spring precipitation, showed a five-fold increase over last year's.

Table 4. Plant density and cover on CAU 400-Bomblet Pit

Plant Density (\# Plants $/ \mathbf{m}^{2}$ )

Shrubs Bud sagebrush

Fourwing saltbush

Shadscale

Winterfat

Total Shrubs

Grasses Squirreltail

Galleta

Indian ricegrass

Total Grasses

Total Perennials

Total Annuals

Plant Cover

Shrub

Grass

Perennial Plant Cover

Annuals (not seeded)

Bare Ground/Rock

Litter/Mulch

$\begin{array}{cccccc}\frac{\text { May-00 }}{3.8} & \frac{\text { Jun-02 }}{2.5} & \frac{\text { Sept-03 }}{2.6} & \frac{\text { June-04 }}{0.8} & \frac{\text { June-05 }}{0.9} & \frac{\text { Ref 05 }}{2.7} \\ 0.5 & 0.3 & 0.2 & 0.2 & 0.0 & 0.0 \\ 6.8 & 6.5 & 6.4 & 5.3 & 4.7 & 1.1 \\ \underline{0.3} & \underline{0.0} & \underline{0.1} & \underline{0.0} & \underline{0.1} & \underline{0.3} \\ 10.0 & 9.2 & 9.2 & 6.2 & 5.7 & 4.2 \\ 3.1 & 0.0 & 0.0 & 0.0 & 0.0 & 0.0 \\ 0.0 & 0.0 & 0.0 & 0.0 & 0.0 & 0.3 \\ \underline{2.5} & \underline{0.2} & \underline{0.4} & \underline{0.0} & \underline{0.0} & \underline{0.3} \\ 6.9 & 0.2 & 0.4 & 0.0 & 0.0 & 0.6 \\ 16.9 & 9.4 & 9.6 & 6.2 & 5.7 & 4.8 \\ 5.4 & 0.3 & 0.1 & 1.1 & 56.0 & 0.5\end{array}$

$\begin{array}{cccccc}\underline{\text { May-00 }} & \underline{\text { Jun-02 }} & \underline{\text { Sept-03 }} & \underline{\text { June-04 }} & \underline{\text { June-05 }} & \underline{\text { Ref 05 }} \\ 15.8 & 18.8 & 10.0 & 7.5 & 8.8 & 11.3 \\ \underline{2.6} & \underline{0.0} & \underline{0.0} & \underline{0.0} & \underline{0.0} & \underline{0.0} \\ 18.4 & 18.8 & 10.0 & 7.5 & 8.8 & 11.3 \\ 0.0 & 0.0 & 0.0 & 0.0 & 3.8 & 2.5 \\ 63.2 & 61.3 & 73.8 & 78.8 & 72.5 & 70.1 \\ 18.4 & 20.0 & 16.3 & 13.8 & 15.0 & 16.3 \\ \text { Small } & & & & & \\ \begin{array}{c}\text { mammal } \\ \text { burrows }\end{array} & & & & & \\ \text { Stable } & \text { Stable } & \text { Stable } & \text { Stable } & \text { Stable } & \end{array}$

Erosion Classification

Stable Stable Stable Stable Stable 
Post-Closure Inspection Report - TTR

Revision: 0

Date: June 2006

Plant cover increased by about $17 \%$ over an all time low of $7.5 \%$ in 2004 (Table 4). The composition of plant cover, like plant density, was $100 \%$ shrub, which is the same pattern as in the native plant community. Although density decreased slightly this year, those plants that have survived the drought conditions of the last few years, are showing good signs of growth.

There were no signs of herbivory or erosion at this site. The invasion of the site by halogeton, a noxious weed that dominated the area prior to closure, still does not appear to be a problem. After reaching a maximum density of 27.4 plants $/ \mathrm{m}^{2}$ in 1999 , the density of halogeton declined to 0.1 plants $/ \mathrm{m}^{2}$ from 2002 to 2004 and this year was not found on the site.

\section{CAU 404-ROLLERCOASTER SEWAGE LAGOONS}

Plant density on the staging area at the Rollercoaster sewage lagoon site as leveled off at about 6.5 plants $/ \mathrm{m}^{2}$. Plant densities were higher the first couple years but since 2002 there have only been slight changes. The ratio of shrubs and grasses continues to be about the same also. There are about 6.2 shrubs $/ \mathrm{m}^{2}$ and 0.2 to 0.3 grasses $/ \mathrm{m}^{2}$.

Perennial plant cover increased from 17\% in 2004 to 20\% in 2005 (Table 5). The contribution of grasses to overall plant cover has always been low on the staging area and that trend continued this year. Less than $1 \%$ of the cover was from grasses. For the first time forbs contributed to overall plant cover.

There are several small mammal burrows scattered over the site. There is not indication that rabbits are heavily browsing the plants on the site.

The only indication of erosion is around the main gate. There is evidence of some overland water flow from off the access road. There are no recent signs of erosion. The overland flow occurred during the summer of 2003 from some intensive thunderstorms that passed through the area. Plants do not seem to have been affected. There are no signs of rilling or channeling.

Halogeton, a noxious weed, is present on the staging area as well as in the native plant community (Reference Area). The density of halogeton was 1.6 plants $/ \mathrm{m}^{2}$ in 2004 , but dropped to 0.1 plants $/ \mathrm{m}^{2}$ in 2005. The establishment of both perennial and annual native plants should be detrimental to the success of halogeton at this site.

Plant density is maintaining at about 13 plants $/ \mathrm{m}^{2}$ on the cover cap (Table 5). Eight of the plants are shrubs and five are grasses. Shadscale continues to be the most dominant species. Bud sagebrush and fourwing saltbush are present but at lower densities. Galleta grass is the most common grass. The only other grass encountered was Indian ricegrass which decline slightly this year in comparison to 2004. Squirreltail grass was not found last year but there were a few plants encountered this year. There was an abundance of annuals this year, more than in any other year. 
Post-Closure Inspection Report - TTR Revision: 0

Date: June 2006

Plant cover on the cover cap was the highest this year than it has ever been. The $28.8 \%$

represents almost twice as much cover this year on the staging area as last year (Table 5). Shrub cover this year is almost twice as much as it has been in any other year. There was almost four times as much grass cover this year as there was last year, but still not as high as it was the first couple years after revegetation when grasses were more abundant. Annuals contributed another $7.5 \%$ to overall plant cover this year which is a $6 \%$ increase over last year, which was the first year annuals contributed at all to plant cover.

Table 5. Plant density and cover on CAU 404-Rollercoaster Sewage Lagoons: Staging Area

\begin{tabular}{|c|c|c|c|c|c|c|c|}
\hline \multicolumn{2}{|c|}{ Plant Density (\# Plants / $\mathbf{m}^{2}$ ) } & May-00 & $\underline{\text { Jun-02 }}$ & $\underline{\text { Sept-03 }}$ & June-04 & $\underline{\text { June-05 }}$ & $\underline{\text { Ref } 05}$ \\
\hline \multirow[t]{5}{*}{ Shrubs } & Bud sagebrush & 1.7 & 1.2 & 0.8 & 0.6 & 0.6 & 3.1 \\
\hline & Fourwing saltbush & 0.3 & 0.2 & 0.1 & 0.1 & 0.1 & 0.0 \\
\hline & Shadscale & 10.0 & 6.9 & 5.5 & 5.4 & 5.4 & 1.0 \\
\hline & Winterfat & $\underline{0.0}$ & 0.1 & $\underline{0.1}$ & $\underline{0.1}$ & $\underline{0.1}$ & 0.1 \\
\hline & Total Shrubs & 12.1 & 8.4 & 6.4 & 6.2 & 6.2 & 4.2 \\
\hline \multirow[t]{4}{*}{ Grasses } & Squirreltail & 6.2 & 0.1 & 0.0 & 0.0 & 0.0 & 0.0 \\
\hline & Galleta & 0.8 & 0.3 & 0.2 & 0.1 & 0.2 & 1.2 \\
\hline & Indian ricegrass & 2.5 & $\underline{0.5}$ & $\underline{0.0}$ & $\underline{0.1}$ & 0.03 & 0.2 \\
\hline & Total Grasses & 9.5 & 0.9 & 0.3 & 0.2 & 0.3 & 1.4 \\
\hline \multicolumn{2}{|c|}{ Total Perennials } & 21.6 & 9.3 & 6.7 & 6.4 & 6.5 & 5.6 \\
\hline Total & Annuals & 3.5 & 0.7 & 0.7 & 1.9 & 25.3 & 38.5 \\
\hline
\end{tabular}

Plant Cover

Shrub
Grass
Perennial Plant Cover
Annuals (not seeded)
Bare Ground/Rock
Litter/Mulch

Wildlife

Erosion Classification

\begin{tabular}{|c|c|c|c|c|c|}
\hline May-00 & Jun-02 & Sept-03 & $\underline{\text { June-04 }}$ & June-05 & $\underline{\text { Ref } 05}$ \\
\hline 9.0 & 18.5 & 13.5 & 17.0 & 19.5 & 7.0 \\
\hline 3.5 & $\underline{0.5}$ & $\underline{0.5}$ & $\underline{0.0}$ & $\underline{0.5}$ & $\underline{1.0}$ \\
\hline 12.5 & 19.0 & 14.0 & 17.0 & 20.0 & 8.0 \\
\hline 0.0 & 0.0 & 0.5 & 0.0 & 3.5 & 5.5 \\
\hline 56.5 & 53.0 & 69.0 & 61.5 & 69.0 & 76.5 \\
\hline 31.0 & 28.0 & 16.5 & 21.5 & 7.5 & 10.0 \\
\hline
\end{tabular}

Stable Slight Slight Stable Stable

There are still a number of small mammal burrows around the base of the cover cap, but they do not appear to be detrimental to the integrity of the cover cap nor has there been an associated increase in erosion around the disturbed soils. There is an abundance of mature native shrubs and grasses around the periphery which have probably buffered the effect of the disturbed soils. 
Post-Closure Inspection Report - TTR Revision: 0

Date: June 2006

Table 6. Plant density and cover on CAU 404-Rollercoaster Sewage Lagoons: Cover Cap

\begin{tabular}{|c|c|c|c|c|c|c|c|}
\hline \multicolumn{2}{|c|}{ Plant Density (\# Plants / $\mathbf{m}^{2}$ ) } & May-00 & $\underline{\text { Jun-02 }}$ & $\underline{\text { Sept-03 }}$ & June-04 & June-05 & $\underline{\text { Ref } 05}$ \\
\hline \multirow[t]{5}{*}{ Shrubs } & Bud sagebrush & 2.1 & 1.7 & 1.2 & 1.0 & 0.9 & 3.1 \\
\hline & Fourwing saltbush & 0.9 & 0.6 & 0.3 & 0.5 & 0.6 & 0.0 \\
\hline & Shadscale & 10.9 & 7.0 & 7.0 & 5.9 & 6.6 & 1.0 \\
\hline & Winterfat & $\underline{0.3}$ & $\underline{0.1}$ & $\underline{0.0}$ & $\underline{0.0}$ & $\underline{0.0}$ & $\underline{0.1}$ \\
\hline & Total Shrubs & 14.2 & 9.3 & 8.4 & 7.3 & 8.1 & 4.2 \\
\hline \multirow[t]{4}{*}{ Grasses } & Squirreltail & 10.8 & 1.6 & 0.1 & 0.0 & 0.1 & 0.0 \\
\hline & Galleta & 8.6 & 4.7 & 4.9 & 5.2 & 5.1 & 1.2 \\
\hline & Indian ricegrass & $\underline{3.8}$ & $\underline{2.8}$ & $\underline{1.1}$ & $\underline{0.6}$ & $\underline{0.2}$ & $\underline{0.2}$ \\
\hline & Total Grasses & 23.2 & 9.0 & 6.0 & 5.8 & 5.4 & 1.4 \\
\hline \multicolumn{2}{|c|}{ Total Perennials } & 37.5 & 18.3 & 14.4 & 13.1 & 13.5 & 5.6 \\
\hline Total & Annuals & 0.5 & 0.3 & 0.2 & 1.9 & 31.5 & 38.5 \\
\hline \multirow[t]{7}{*}{ Plant Cover } & & $\underline{\text { May-00 }}$ & $\underline{\text { Jun-02 }}$ & $\underline{\text { Sept-03 }}$ & June-04 & June-05 & $\underline{\text { Ref } 05}$ \\
\hline & Shrub & 6.3 & 10.0 & 12.5 & 10.0 & 18.8 & 7.0 \\
\hline & Grass & $\underline{12.5}$ & $\underline{16.3}$ & $\underline{10.0}$ & $\underline{3.8}$ & $\underline{10.0}$ & $\underline{1.0}$ \\
\hline & Perennial Plant Cover & 18.8 & 26.3 & 22.5 & 13.8 & 28.8 & 8.0 \\
\hline & Annuals & 0.0 & 0.0 & 0.0 & 1.3 & 7.5 & 5.5 \\
\hline & Bare Ground/Rock & 73.8 & 65.0 & 71.3 & 77.5 & 57.5 & 76.5 \\
\hline & Litter/Mulch & 7.5 & 9.0 & 6.3 & 7.5 & 6.3 & 10.0 \\
\hline
\end{tabular}

\section{Wildlife}

Erosion Classification

Stable Stable Stable Stable Stable

* Density of Annuals not recorded for reference site in 2005

\section{CAU 426-CACTUS SPRINGS WASTE TRENCHES}

Plant density on the staging area was more than double this year what it was last year (Table 7). The number of shrubs was about the same but like last year there were more than twice as many grasses this year than there were the year before. In the last two years the number of grasses has increased from $1.6 / \mathrm{m}^{2}$ in 2003 to $6.3 / \mathrm{m}^{2}$ this year. Squirreltail grass continues to be the most abundant grass at the site. Indian ricegrass is the next most common. Plant densities for both species more than doubled from what they were the year before. 
Post-Closure Inspection Report - TTR Revision: 0

Date: June 2006

Table 7. Plant density and cover on CAU 426-Cactus Springs Waste Trenches: Staging Area

\begin{tabular}{|c|c|c|c|c|c|c|c|}
\hline \multicolumn{2}{|c|}{ Plant Density (\# Plants /m²) } & May-00 & $\underline{\text { Jun-02 }}$ & $\underline{\text { Sept-03 }}$ & $\underline{\text { June-04 }}$ & $\underline{\text { June-05 }}$ & $\underline{\text { Ref } 05}$ \\
\hline \multirow[t]{9}{*}{ Shrubs } & Black sagebrush & 0.0 & 0.1 & 0.0 & 0.0 & 0.0 & 0.8 \\
\hline & Bud sagebrush & 0.0 & 0.1 & 0.0 & 0.0 & 0.0 & 0.0 \\
\hline & Fourwing saltbush & 0.1 & 0.0 & 0.0 & 0.0 & 0.1 & 0.0 \\
\hline & Shadscale & 0.1 & 0.0 & 0.0 & 0.1 & 0.0 & 0.3 \\
\hline & Nevada jointfir & 0.3 & 0.2 & 0.3 & 0.1 & 0.3 & 0.2 \\
\hline & Douglas'rabbitbrush & 0.1 & 0.1 & 0.2 & 0.1 & 0.2 & 0.0 \\
\hline & Rubber rabbitbrush & 0.1 & 0.0 & 0.1 & 0.1 & 0.0 & 0.1 \\
\hline & Winterfat & $\underline{0.0}$ & $\underline{0.0}$ & $\underline{0.0}$ & $\underline{0.0}$ & $\underline{0.1}$ & $\underline{0.0}$ \\
\hline & Total Shrubs & 0.7 & 0.5 & 0.6 & 0.5 & 0.6 & 1.3 \\
\hline \multirow[t]{4}{*}{ Grasses } & Squirreltail & 5.2 & 2.9 & 0.6 & 1.9 & 5.1 & 0.1 \\
\hline & Galleta & 0.2 & 0.1 & 0.3 & 0.3 & 0.0 & 2.4 \\
\hline & Indian ricegrass & 1.4 & $\underline{0.6}$ & $\underline{0.7}$ & $\underline{0.4}$ & $\underline{1.3}$ & $\underline{0.0}$ \\
\hline & Total Grasses & $\overline{6.8}$ & $\overline{3.5}$ & $\overline{1.6}$ & $\overline{2.6}$ & $\overline{6.3}$ & $\overline{2.5}$ \\
\hline \multicolumn{2}{|c|}{ Total Perennials } & 7.5 & 4.0 & 2.2 & 3.1 & 6.9 & 3.8 \\
\hline \multicolumn{2}{|c|}{ Total Annuals } & 16.9 & 1.8 & 3.9 & 3.2 & 16.6 & $*$ \\
\hline \multirow[t]{7}{*}{ Plant Cover } & & May-00 & $\underline{\text { Jun-02 }}$ & $\underline{\text { Sept-03 }}$ & June-04 & $\underline{\text { June-05 }}$ & $\underline{\text { Ref } 05}$ \\
\hline & Shrub & 0.8 & 5.0 & 2.5 & 3.3 & 5.1 & 11.7 \\
\hline & Grass & $\underline{5.8}$ & $\underline{12.5}$ & $\underline{6.7}$ & $\underline{10.8}$ & $\underline{17.1}$ & $\underline{0.8}$ \\
\hline & Perennial Plant Cover & 6.6 & 17.5 & 9.2 & 14.1 & 23.2 & 12.5 \\
\hline & Annuals (not seeded) & 0.0 & 1.7 & 5.0 & 2.5 & 10.3 & 1.7 \\
\hline & Bare Ground/Rock & 50 & 42.5 & 50.0 & 59.2 & 47.0 & 75.8 \\
\hline & Litter/Mulch & 43.3 & 38.3 & 35.8 & 24.2 & 20.5 & 10.0 \\
\hline
\end{tabular}

Wildlife

Erosion Classification

Stable Stable Stable Stable Stable

* Density of Annuals not recorded for reference site in 2005

There were 16.6 annual plants $/ \mathrm{m}^{2}$ found on the staging area at the Cactus Springs waste trenches site. Of those 16.6 plants $/ \mathrm{m}^{2}, 6.2$ or about one-third of the annual species are halogeton. Densities decreased to 2.4 plants $/ \mathrm{m}^{2}$ in 2004 . Although density decreased this year, the density of halogeton is higher than any other species found at this site.

Perennial plant cover was the highest it has ever been on the staging area (Table 7). The 23.2\% plant cover this year represents a 65\% increase over last year. Shrub cover increased from 3.3\% 
Post-Closure Inspection Report - TTR Revision: 0

Date: June 2006

to $5.1 \%$ and grass cover from $10.8 \%$ to $17.1 \%$. In addition to the perennial plant cover, annual forbs contributed another $10.3 \%$ to overall plant cover.

There are a few small mammal burrows on the staging area. There are no signs of erosion.

Plant cover on the cover cap at the Cactus Springs waste trenches decreased to $10 \%$ this year, a decline of $7 \%$ over last year and the year before. All of the perennial plant cover was from shrubs, which is the first year since monitoring began that grasses have not contributed to perennial plant cover. Annual plants contributed to overall cover this year for the first time.

Table 8. Plant density and cover on CAU 426-Cactus Springs Waste Trenches: Cover Cap

Plant Density (\# Plants $/ \mathbf{m}^{2}$ )

Shrubs

Bud sagebrush

Fourwing saltbush

Shadscale

Nevada jointfir

Douglas'rabbitbrush

Rubber rabbitbrush

Winterfat

Total Shrubs

Grasses Squirreltail

Galleta

Indian ricegrass

Total Grasses

Total Perennials

Total Annuals

Plant Cover (\%)

Shrub

Grass

Perennial Plant Cover

Annuals (not seeded)

Bare Ground/Rock

Litter/Mulch

\section{$\underline{\text { May-00 }}$}

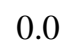

0.0

0.0

0.0

1.0

0.1

0.1

$\underline{0.1}$

1.3

1.0

1.4

1.3

3.7

5.0

0.1

1.1

0.3

0.0

May-00

0.0

Jun-0

3.3

3.3

0.0

85.0

11.7

6.7

8.3

15.0

0.0

78.3

6.7

80.0

3.3

3.3

5.0

75.8

10.0

Wildlife

Erosion Classification

Stable Stable Stable Stable Stable 
Post-Closure Inspection Report - TTR

Revision: 0

Date: June 2006

There were some signs of rabbit scat, but there was no evidence of excessive browsing on the shrubs. There were no signs of erosion on the cover cap.

\section{E. CAU 407-ROLLERCOASTER RADSAFE}

This is the first year the vegetation was sampled at this site. In previous years the only plants present on the cover cap were annual weedy species. Only plant densities were recorded this year. Total plant density was 82.8 plants $/ \mathrm{m}^{2}$, which is relatively high in comparison to other closure sites. The number represents young seedlings which over time will naturally thin to a level the environmental conditions at the site will support. Two shrub species (Nevada jointfir and rubber rabbitbrush) that were included in the seed mix were not detected during sampling this year. Shadscale was by far the most abundant species followed by bud sagebrush, fourwing saltbush and winterfat. Galleta was the only species of grass that was not found on the site this spring. Galleta is a warm season grass and germination may have occurred after sampling was completed and will be detected during next year's sampling. Squirreltail grass was the most abundant grass found at the site. Indian ricegrass was present but at a density $1 / 3$ of squirreltail grass.

Table 9. Plant cover at CAU 407-Rollercoaster RADSAFE Area

\begin{tabular}{|c|c|c|c|}
\hline \multicolumn{2}{|c|}{ Plant Density (\# Plants $/ \mathbf{m}^{2}$ ) } & $\underline{\text { June-05 }}$ & $\underline{\text { Ref } 05}$ \\
\hline \multirow[t]{7}{*}{ Shrubs } & Bud sagebrush & 2.9 & 3.1 \\
\hline & Fourwing saltbush & 2.3 & 0.0 \\
\hline & Shadscale & 17.5 & 1.0 \\
\hline & Nevada jointfir & 0.0 & 0.0 \\
\hline & Rubber rabbitbrush & 0.0 & 0.0 \\
\hline & Winterfat & 0.7 & 0.1 \\
\hline & Total Shrubs & 23.4 & 4.2 \\
\hline \multirow[t]{4}{*}{ Grasses } & Squirreltail & 42.9 & 1.2 \\
\hline & Galleta & 0.0 & 0.0 \\
\hline & Indian ricegrass & 16.4 & $\underline{0.2}$ \\
\hline & Total Grasses & $\overline{59.4}$ & $\overline{1.4}$ \\
\hline \multicolumn{2}{|c|}{ Total Perennial Plants } & 82.8 & 5.6 \\
\hline \multicolumn{2}{|c|}{ Total Annuals } & 1.4 & 38.5 \\
\hline
\end{tabular}

Wildlife

Erosion Classification Stable 
Post-Closure Inspection Report - TTR

Revision: 0

Date: June 2006

\section{SUMMARY}

Revegetation is typically considered successful when a pre-determined level of perennial plant density and cover is achieved. The pre-determined values are usually a percentage of the plant cover and density on adjacent, undisturbed plant communities that are similar to the vegetation community that had been disturbed and was revegetated. A percentage was not established for the revegetation of any of the closure sites on the Tonopah Test Range, however, a typical percentage used to determine reclamation success is $70 \%$ and is usually made, at the earliest, five years after revegetation is completed and more typically in the tenth year following revegetation. This year is the seventh year since revegetation occurred at CAUs 400-Five Points Landfill, 400Bomblet Pit, 404-Rollercoaster Sewage Lagoons and 426-Cactus Springs Waste Trenches. Undisturbed plant communities, reference sites, are sampled annually at each CAU. Revegetation of CAU 407 originally occurred in 2000 (five years ago), however, the site was disturbed after that time and was seeded again this past fall, 2004.

The plant density and cover estimate data collected this year was summarized and compared to data collected from reference areas. Based on both perennial plant density and perennial plant cover all of the sites exceed the reclamation success goal of $70 \%$ of the density and cover on the respective reference areas.

CAU 400: Five Points Landfill - Plant density at this site is the lowest plant density of any of the CAUs that were revegetated in 1997 (Figure 4). Although there are less than $2 \mathrm{plants} / \mathrm{m}^{2}$ it exceeds the goal of 1.3 plants $/ \mathrm{m}^{2}$. The plants that are establishing on the site are fourwing saltbush, winterfat, squirreltail grass and Indian ricegrass, all species native to the area. This year there was an abundance of native perennial species. To date there have not been any problems with invasive weedy species at this site. The newly reseeded portion of the site should be monitored to insure such species do not impede the establishment of native perennial species.

Plant cover at this site was about $10 \%$, which is the lowest that it has been since the site was reseeded (Figure 5). The low cover is in part due to the dry conditions that have existed at the site for the 2-3 years prior to this year and also to the flash flood that impacted a significant portion of the vegetation last fall. Although plants may not have recovered fully from the drought and flash flood, perennial plant cover still exceeds the plant cover goal of $8 \%$ (70\% of the $11 \%$ measured this year). The drier conditions experienced in this region the previous 3 years appear to have affected grasses more than shrubs. The contribution of grasses to overall perennial plant cover has declined over the last few years from a high of $80 \%$ of the cover in 2000 to only $13 \%$ this year. 


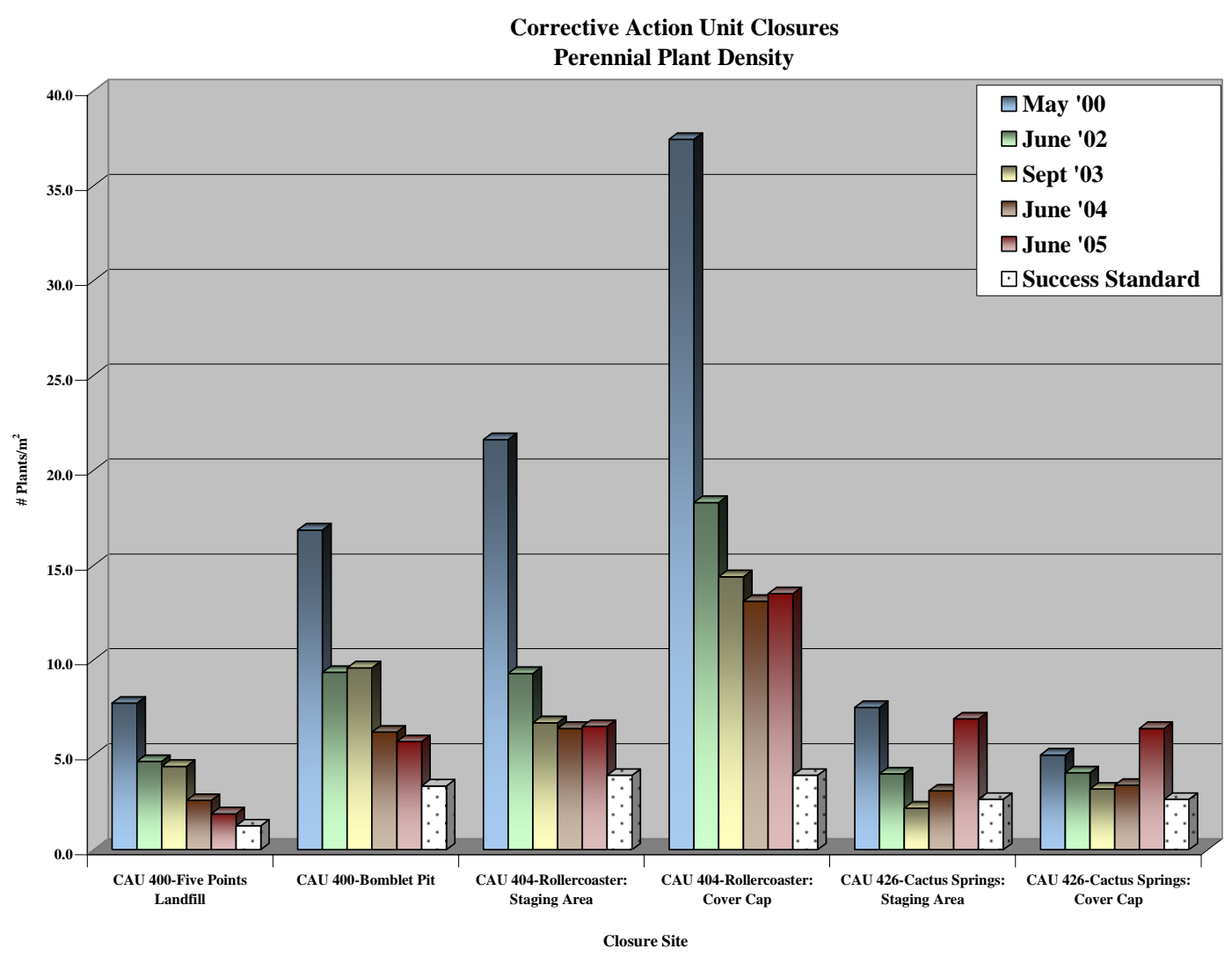

Figure 4. Plant density on all CAU s over the last five years and compared to plant densities on adjacent native plant communities.

CAU 400: Bomblet Pit - Perennial plant density at this site continues at around 6 plants $/ \mathrm{m}^{2}$, which is higher than the density measured on the reference area and almost double the goal of 3.4 plants $/ \mathrm{m}^{2}$ (Figure 4). Over the last couple years density has declined as has plant diversity or the number of different species present on the site. Bud sagebrush, shadscale and winterfat are still found on the site, but this year there were no grasses encountered nor were there any individuals of fourwing saltbush found. Grasses are not an important component of this vegetation type as indicated by density data for the reference area, but Indian ricegrass has been present in previous years. Possibly with more favorable growing conditions, like this year, grasses will again establish and contribute to overall plant density.

Plant cover was not as high on the revegetated site as it was on the reference area, but the goal of $8 \%$ total plant cover was met. There was $8.8 \%$ cover on the revegetated site (Figure 5). It appears that even though plant density has declined, those plants that are present are established and have been able to withstand the previous dry conditions. There has been no grass cover at this site since 2000 . 


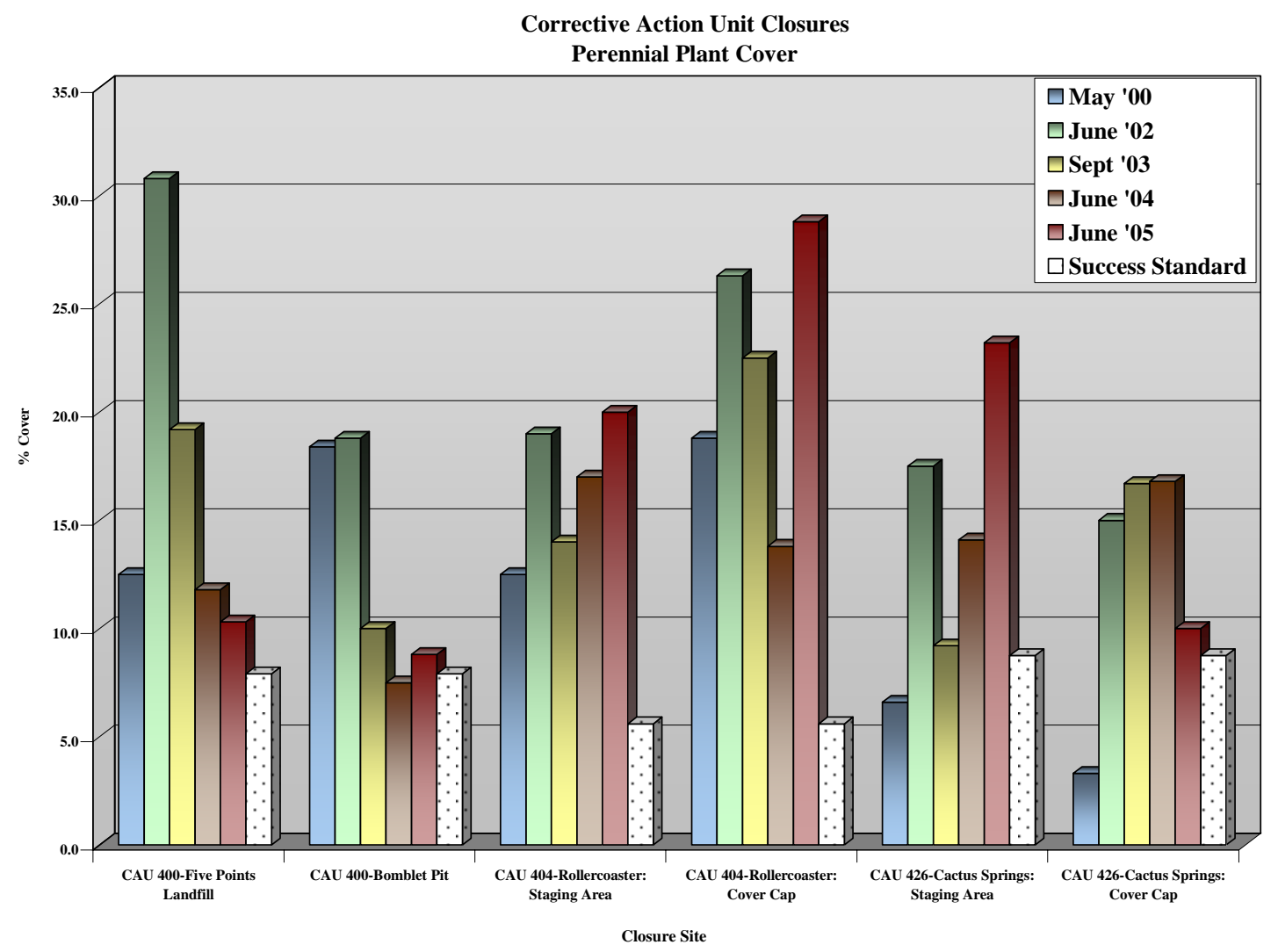

Figure 5. Plant cover for all CAUs over the last five years and compared to plant cover on adjacent native plant communities.

CAU 404: Rollercoaster Sewage Lagoons - Of the four CAU that were revegetated in 1997 the Rollercoaster Sewage Lagoon site has recovered the best from cleanup and closure activities. Perennial plant density on both the staging area and cover cap has been about the same for the past three years (Tables $5 \&$ 6), which is higher than absolute plant density on the reference area. The revegetation goal of about 4 plants $/ \mathrm{m}^{2}$ has been exceed for the past five years (Figure 4). On the cover cap perennial plant density is more than double what it is in the native plant community. Shadscale is by far the most abundant species on both the staging area and cover cap. There is a consistent representation of bud sagebrush, fourwing saltbush, Indian ricegrass and galleta grass.

Plant cover likewise has exceeded the revegetation goal for the last five years (Figure 5). In fact, perennial plant cover on the staging area has been almost double what it has been on the reference area the last couple years. Of some concern is the loss of the contribution of grasses to overall perennial plant cover on the staging area. Only $3-4 \%$ of the total cover is made up of grasses, whereas on the reference area about $13 \%$ of the cover is grass cover. On the cover cap perennial plant cover is even higher and is more than three times what it is on the reference area. Unlike the staging area grasses make up 35\% of the total perennial plant cover on the cover cap. The contribution of grasses has ranged from a high of $66 \%$ in 2000 to a low of only $28 \%$ in 2004. Plant density appears to have stabilized and cover fluctuates with amounts of 
Post-Closure Inspection Report - TTR

Revision: 0

Date: June 2006

precipitation. Perennial plant density and cover on both the staging area and cover cap at CAU 404 have met and exceeded revegetation success goals for the last five years.

CAU 426: Cactus Springs Waste Trenches - This is the first year in several years that perennial plant density on staging area and cover cap have exceeded plant density on the reference area (Tables $7 \& 8$ ). The revegetation goal of 2.7 plants $/ \mathrm{m}^{2}$ has been exceeded every year for the past five years on the cover cap and all except one year on the staging area (Figure 4). On the staging area the majority of the plants are grasses, primarily squirreltail grass with some Indian ricegrass. On the cover cap there is a good representation of both shrubs and grasses. There is an equal representation of two shrubs, Nevada jointfir and rubber rabbitbrush, and about twice as much Indian ricegrass as there is squirreltail grass.

The goal of 9\% perennial plant cover this year on the revegetated sites was exceeded both on the staging area and the cover cap (Tables $7 \& 8$ ). On the staging area cover was more than double this goal. Perennial plant cover on the cover cap met the revegetation goal, but was actually lower than the absolute plant cover on the reference area. This year for the first time there was no perennial grass cover recorded. All of the cover on the cover cap was from shrubs. On the staging area grasses accounted for nearly three-fourths of the total perennial plant cover.

CAU 407: Rollercoaster RADSAFE - Last year the lack of vegetation on the cover cap at this site had resulted in rather severe erosion. Remedial action was taken last fall and the site was revegetated. After one growing season there is an abundance of seedlings of perennial plants. There were seedlings of bud sagebrush, fourwing saltbush, shadscale and winterfat over much of the site along with squirreltail grass and Indian ricegrass. Several species that were seeded but not encountered were Nevada jointfir, rubber rabbitbrush and galleta grass. Hopefully over time some of these species, native to the area, will establish on the site.

Appendices to this report contain a photographic history of revegetated sites (Appendix F.1) and a list of scientific names and common names of plant species encountered during vegetation monitoring (Appendix F.2). 
Post-Closure Inspection Report - TTR

Revision: 0

Date: June 2006

\section{APPENDIX F.1}

\section{Photographic Reference Points}


Post-Closure Inspection Report - TTR Revision: 0

Date: June 2006

CAU 400-FIVE POINTS LANDFILL PHOTOGRAPHIC REFERENCE POINT
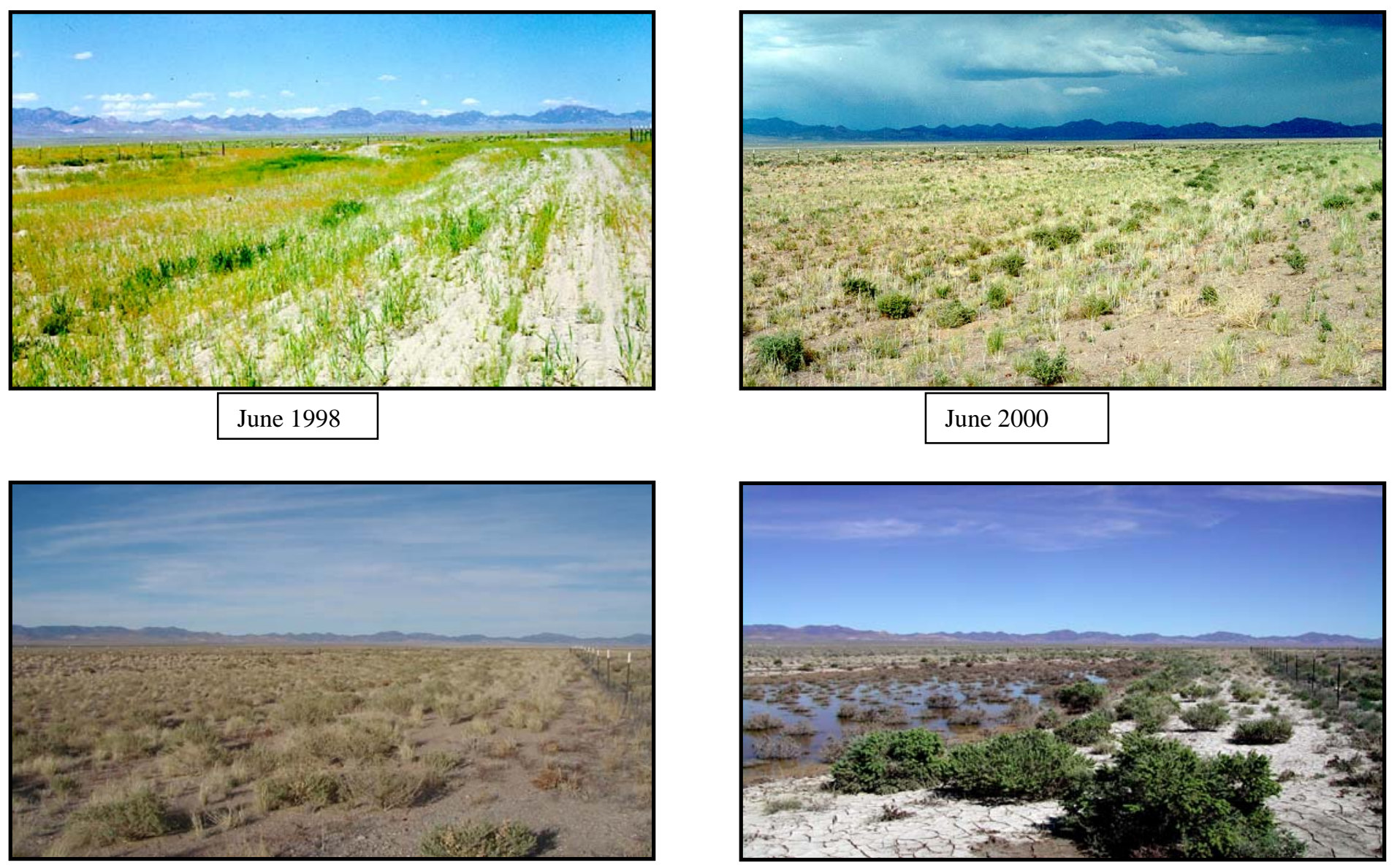

June 2002
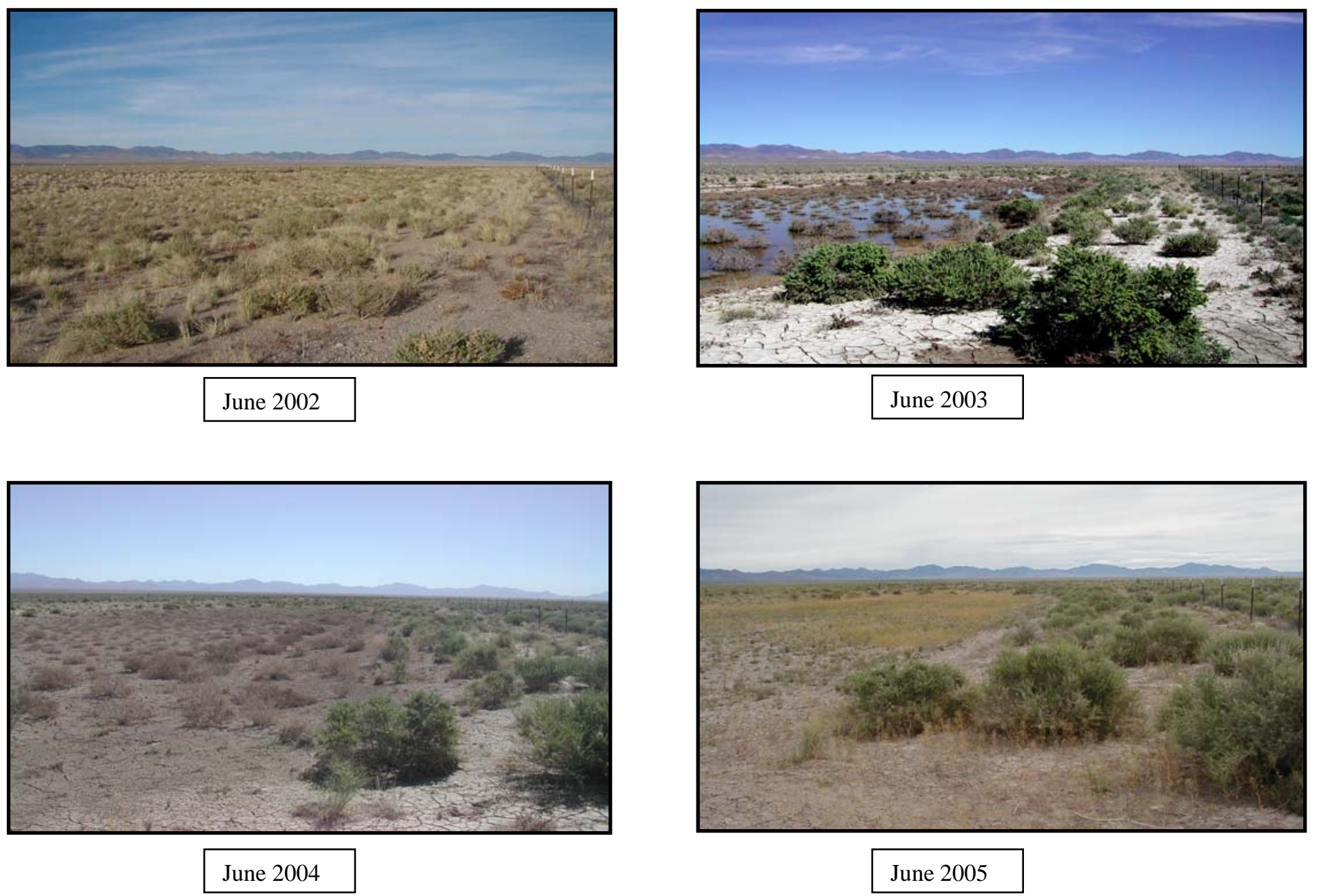

June 2004 
Post-Closure Inspection Report - TTR

Revision: 0

Date: June 2006

\section{CAU 400-BOMBLET PIT \\ PHOTOGRAPHIC REFERENCE POINT}

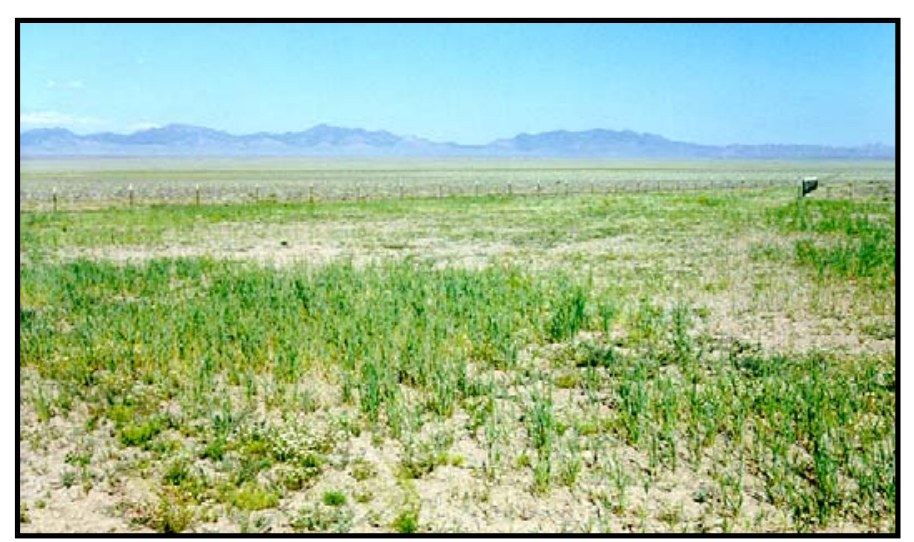

June 1998

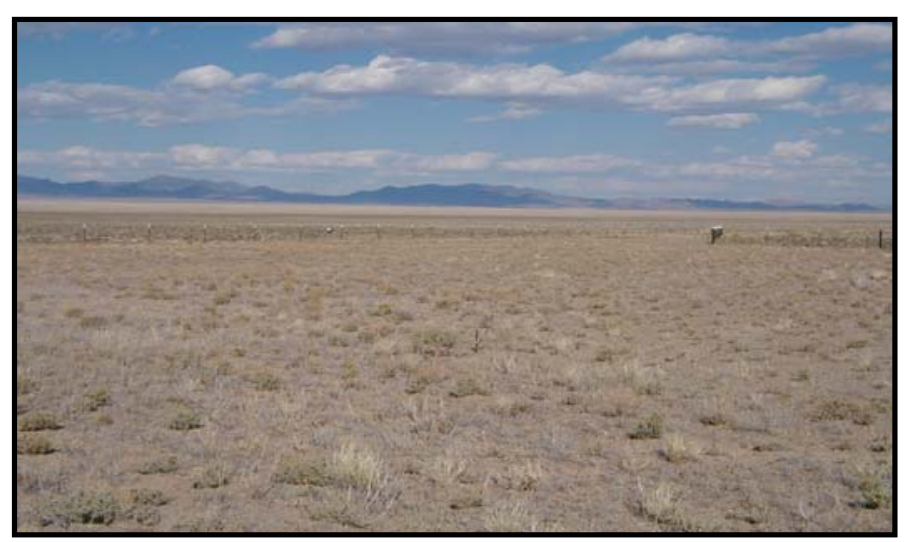

June 2002

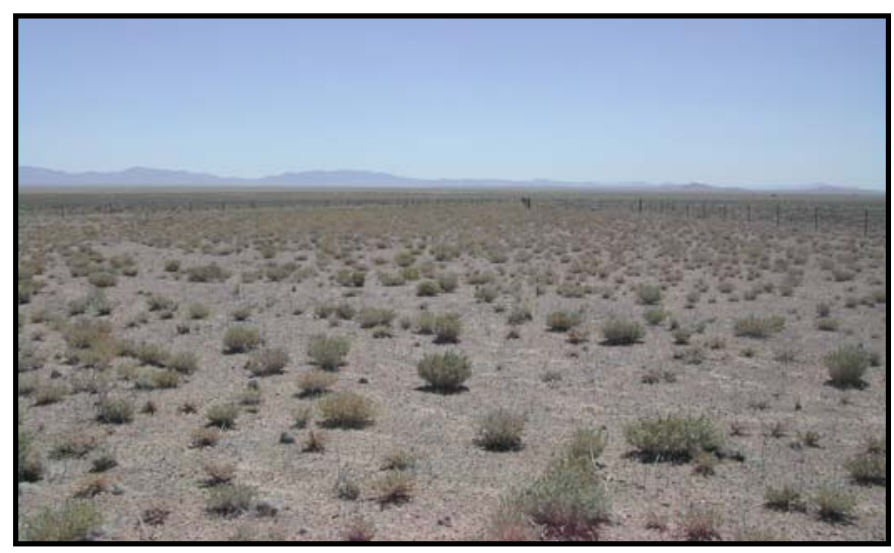

June 2004

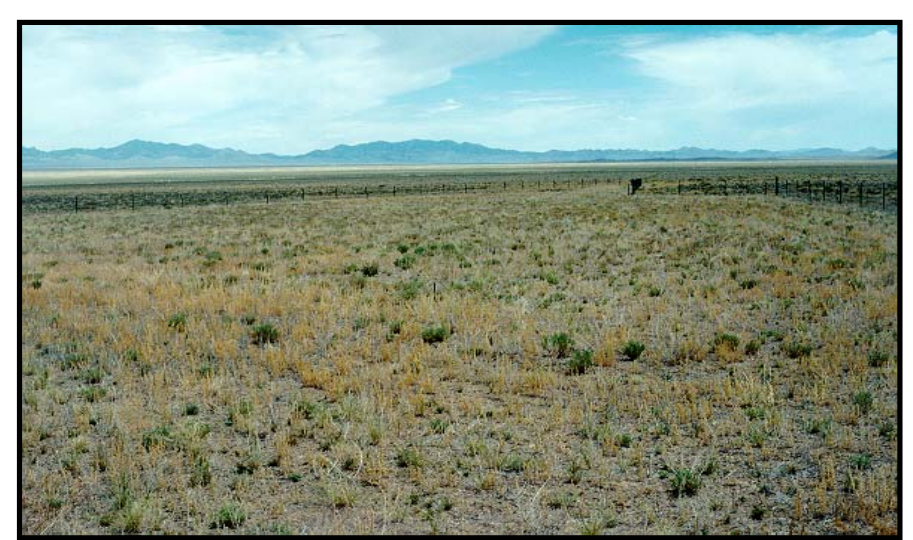

June 2000

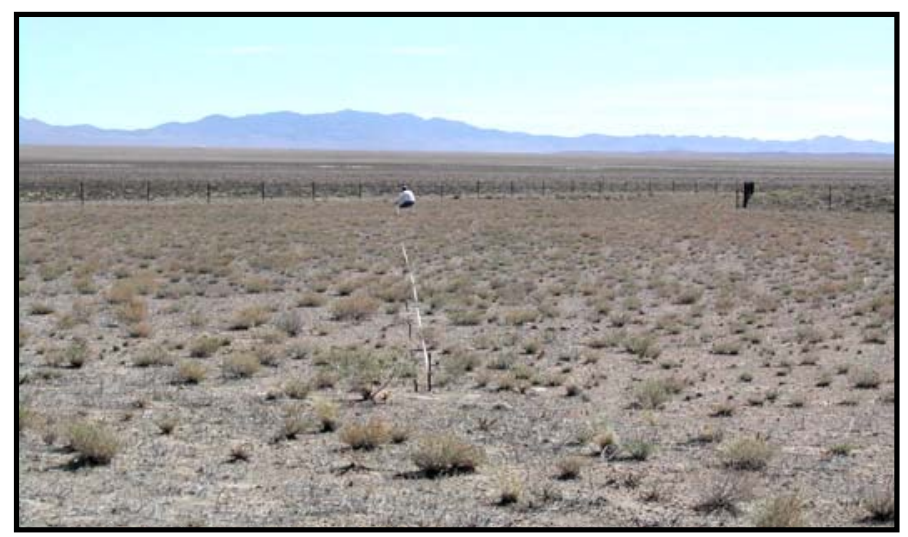

September 2003

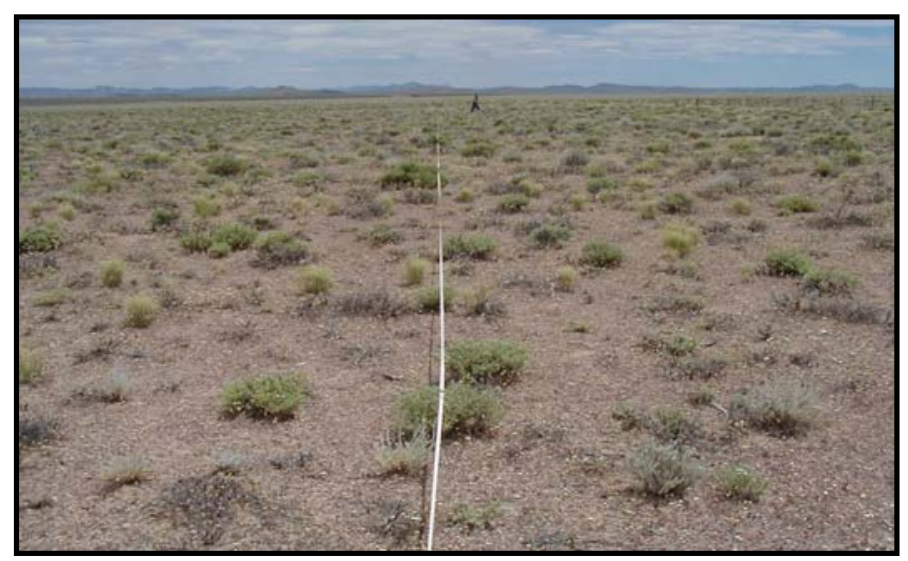

June 2005 
Post-Closure Inspection Report - TTR Revision: 0

Date: June 2006

\section{CAU 404-ROLLERCOASTER SEWAGE LAGOONS COVER CAP PHOTOGRAPHIC REFERENCE POINT}

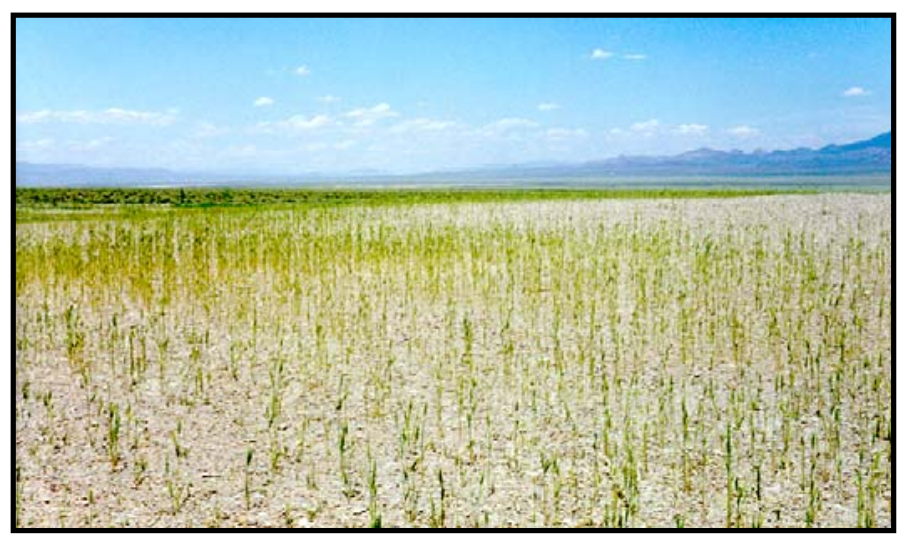

June 1998

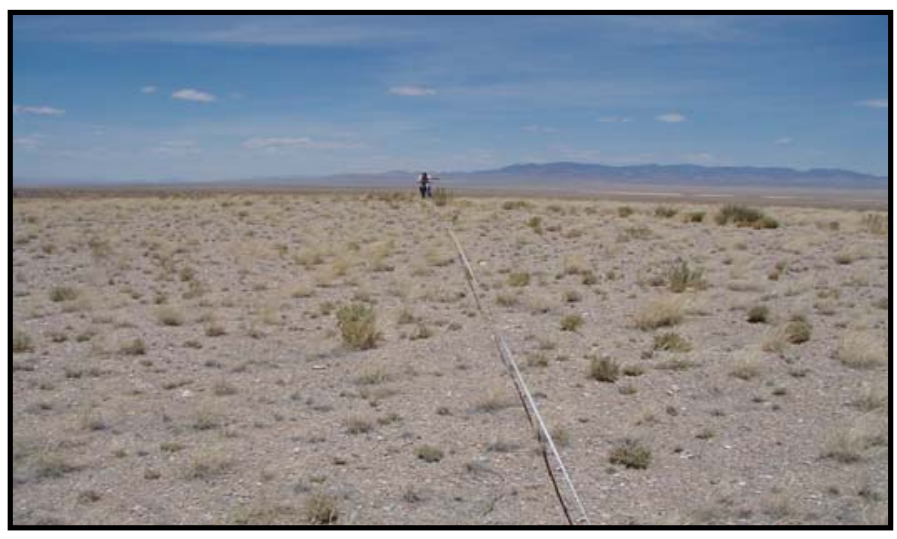

June 2002

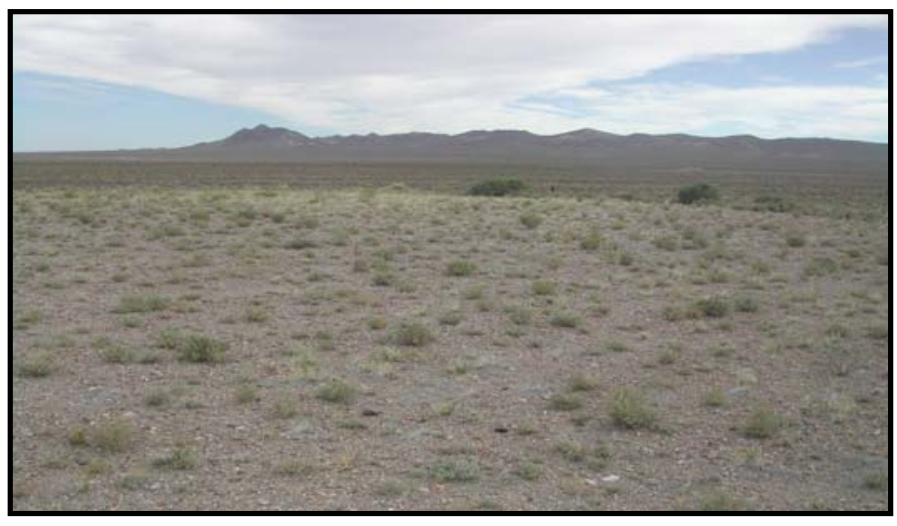

June 2004

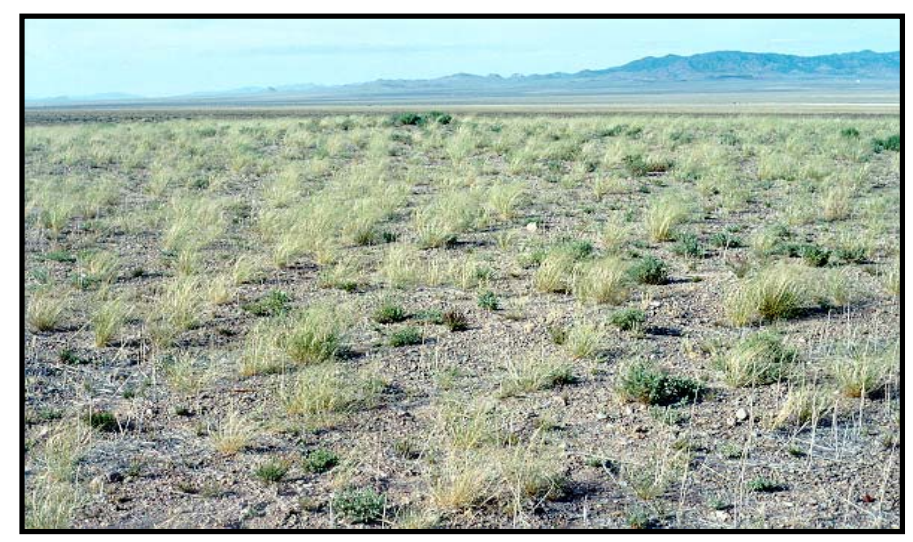

June 2000

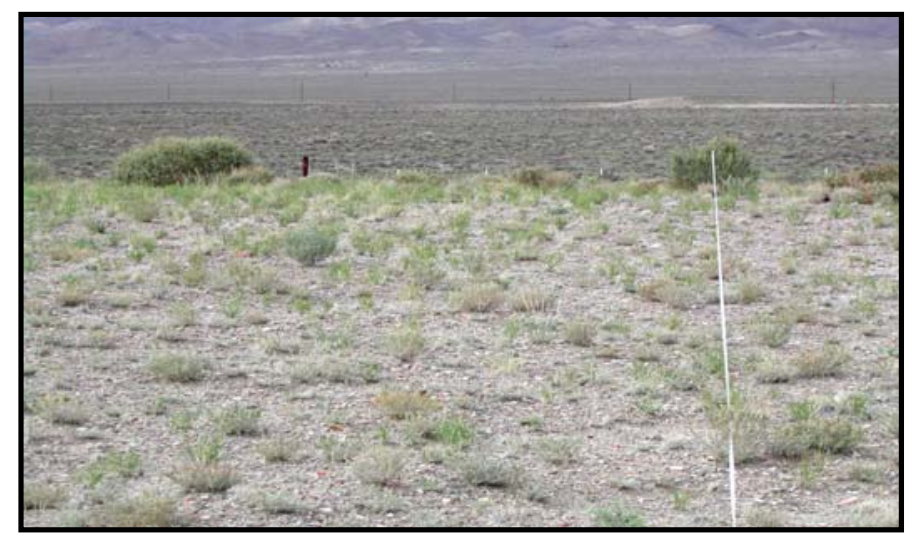

September 2003

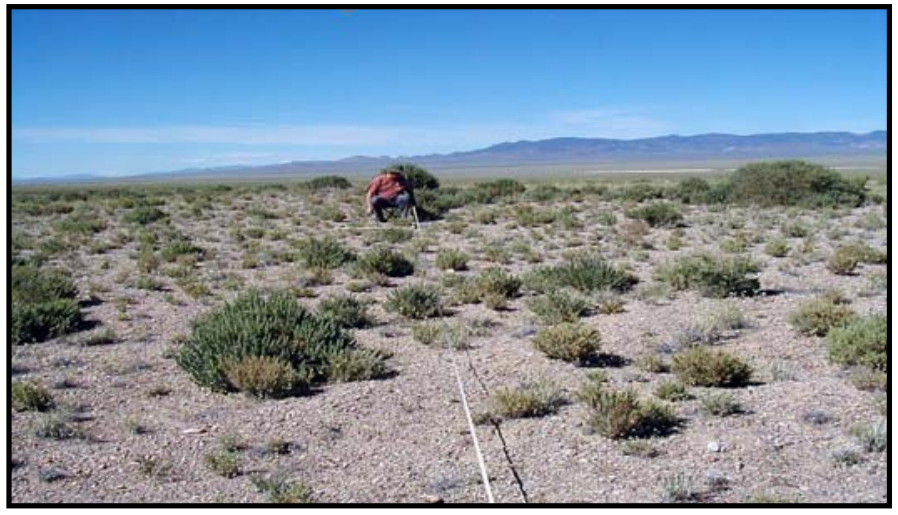

June 2005 
Post-Closure Inspection Report - TTR

Revision: 0

Date: June 2006

\section{CAU 404-ROLLERCOASTER SEWAGE LAGOONS STAGING AREA PHOTOGRAPHIC REFERENCE POINT}

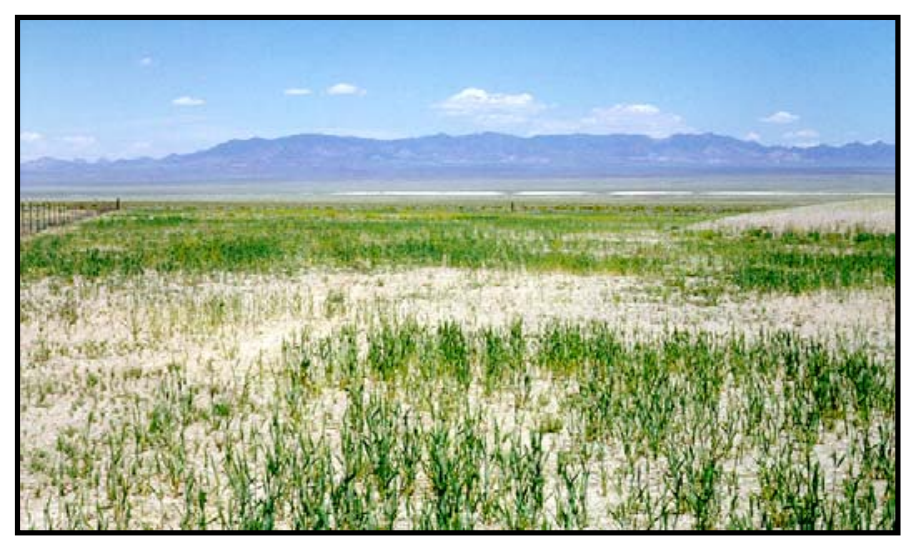

June 1998

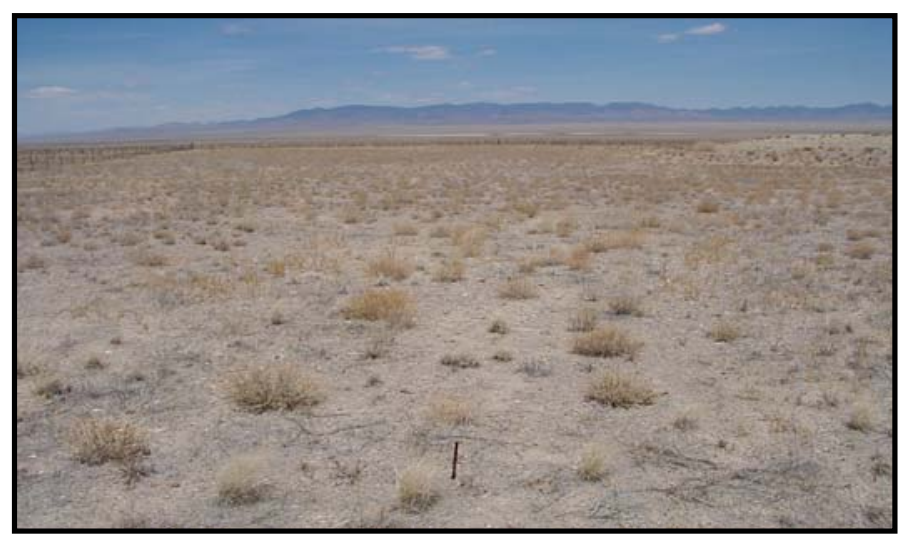

June 2002

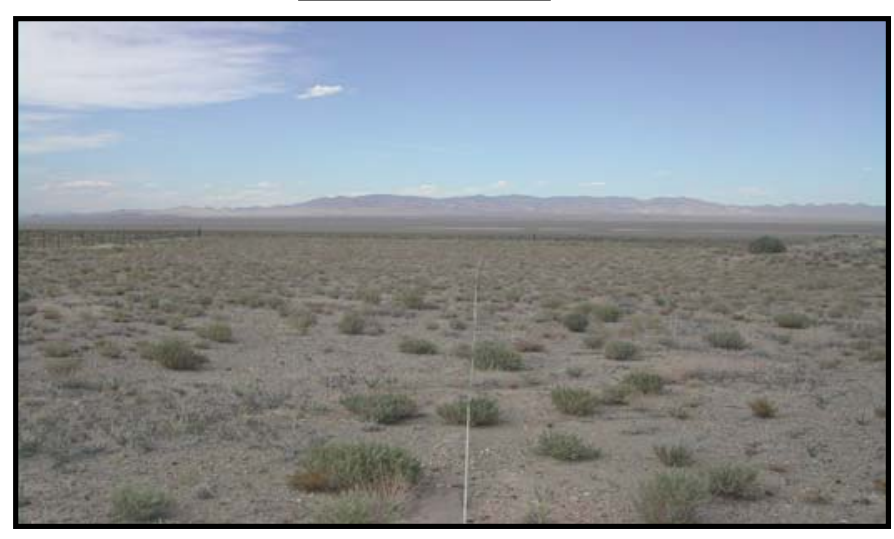

June 2004

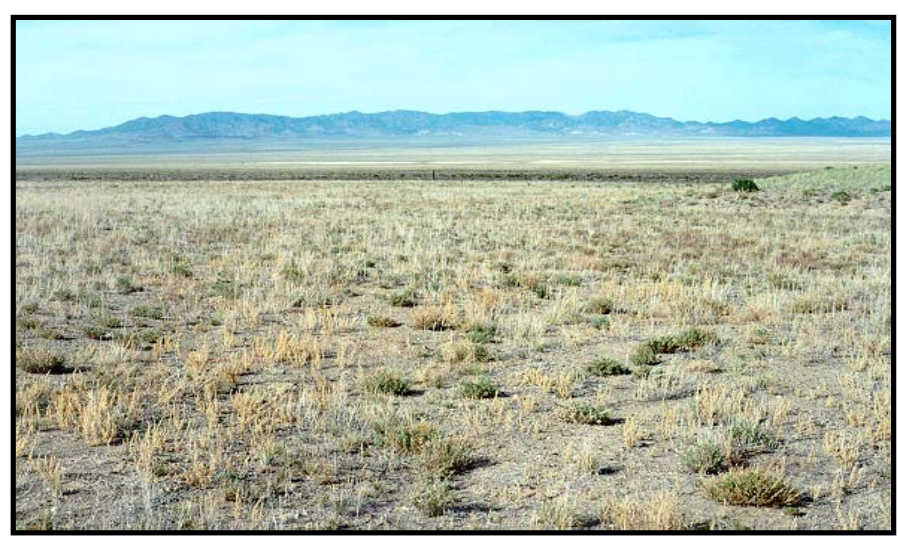

June 2000

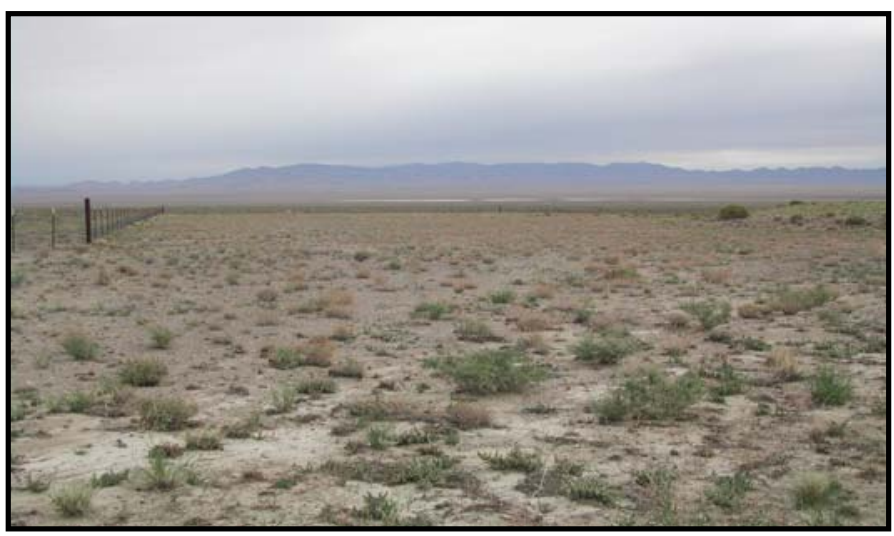

September 2003

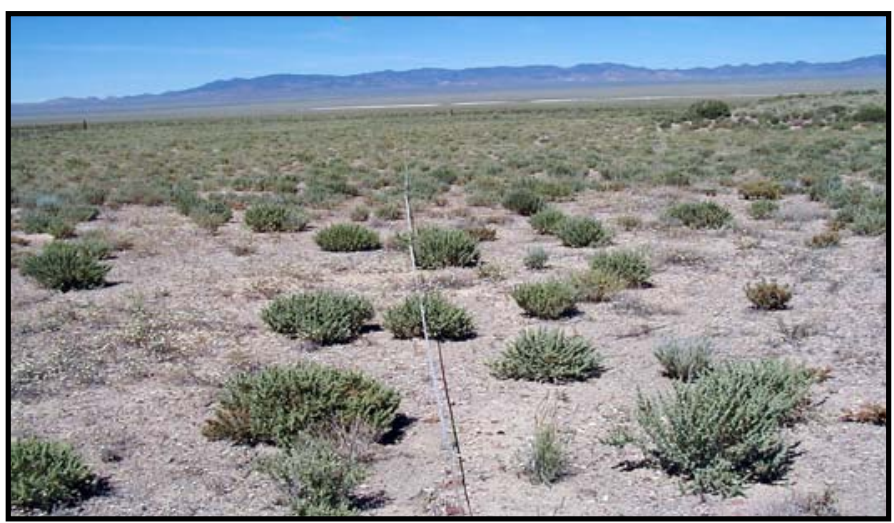

June 2005 
Post-Closure Inspection Report - TTR Revision: 0

Date: June 2006

\section{CAU 426-CACTUS SPRINGS WASTE TRENCH COVER CAP PHOTOGRAPHIC REFERENCE POINT}

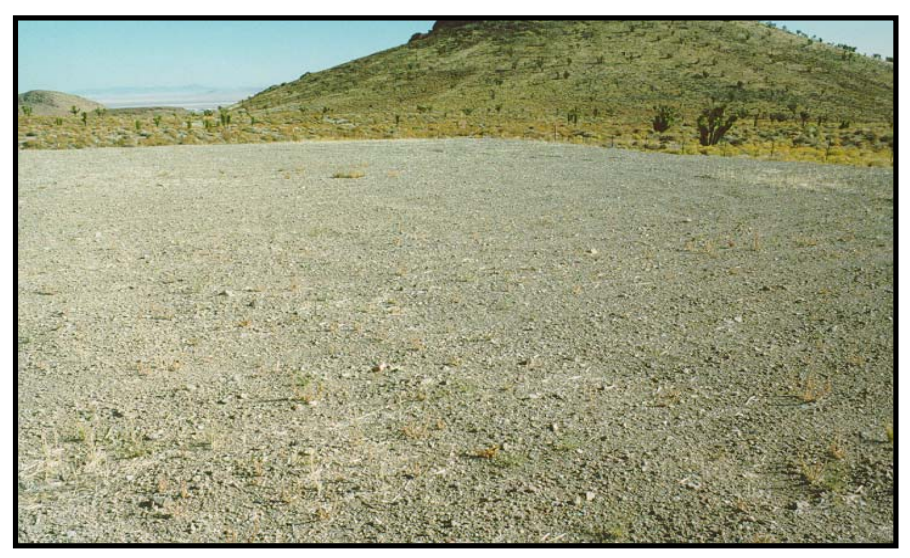

June 1998

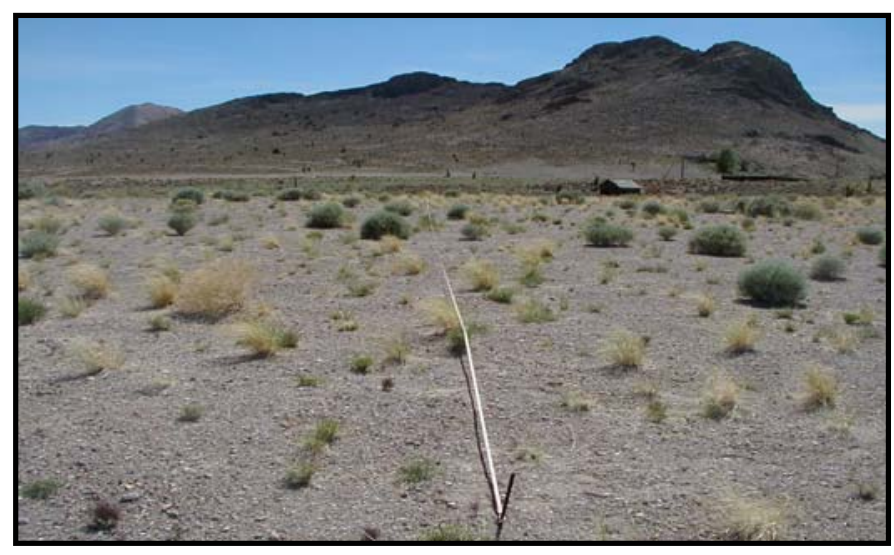

June 2002

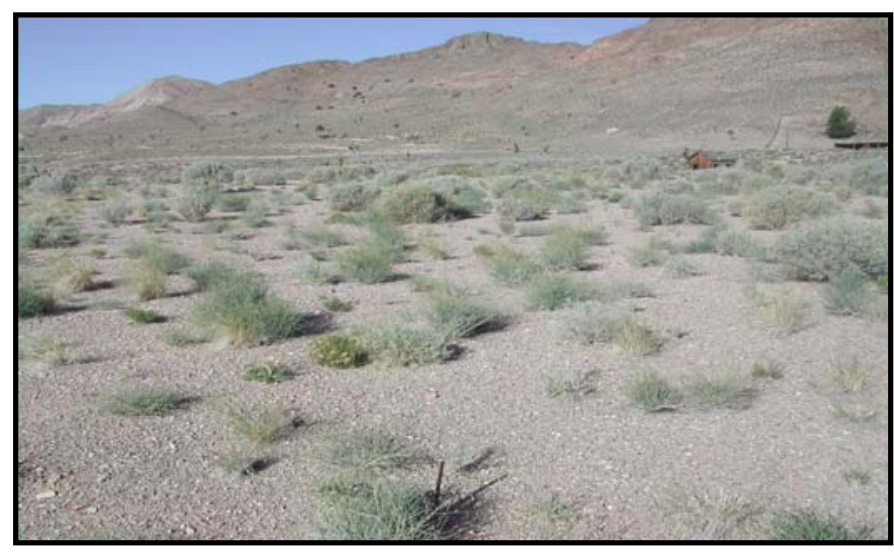

June 2004

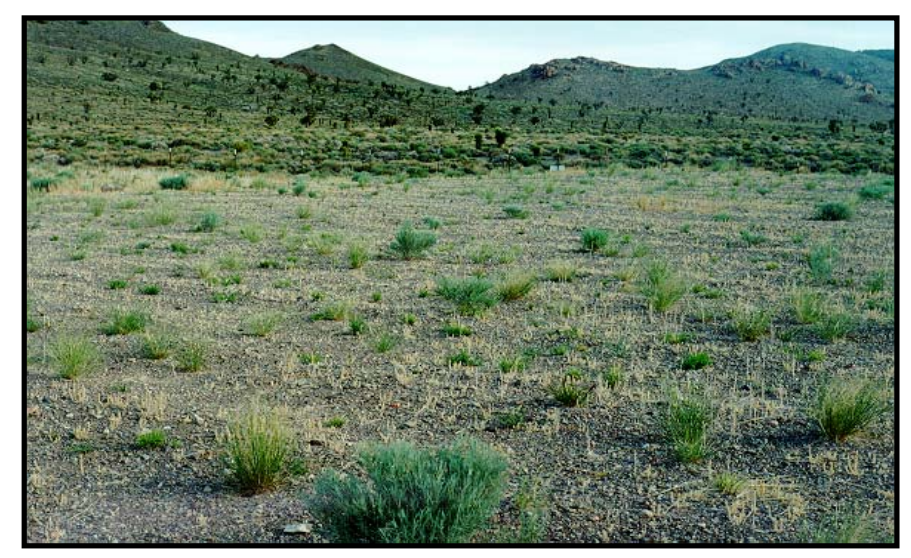

June 2000

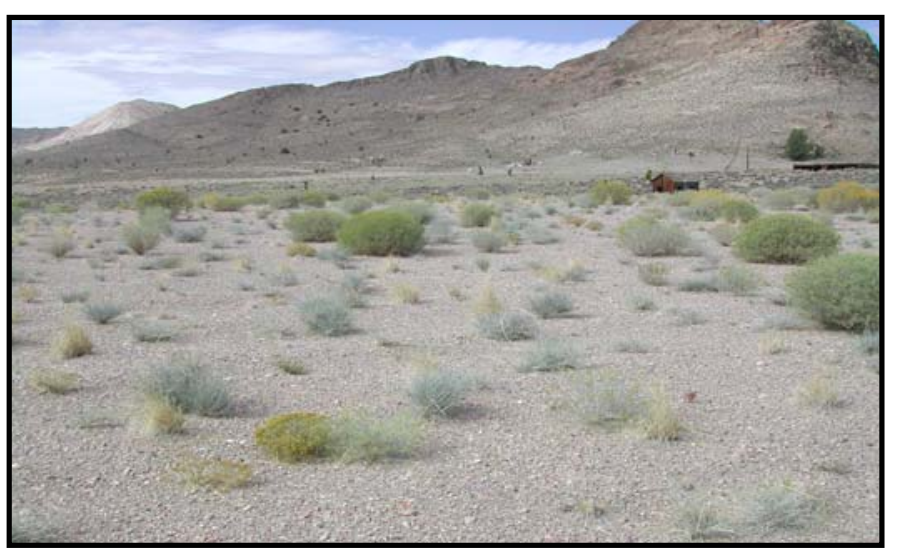

September 2003

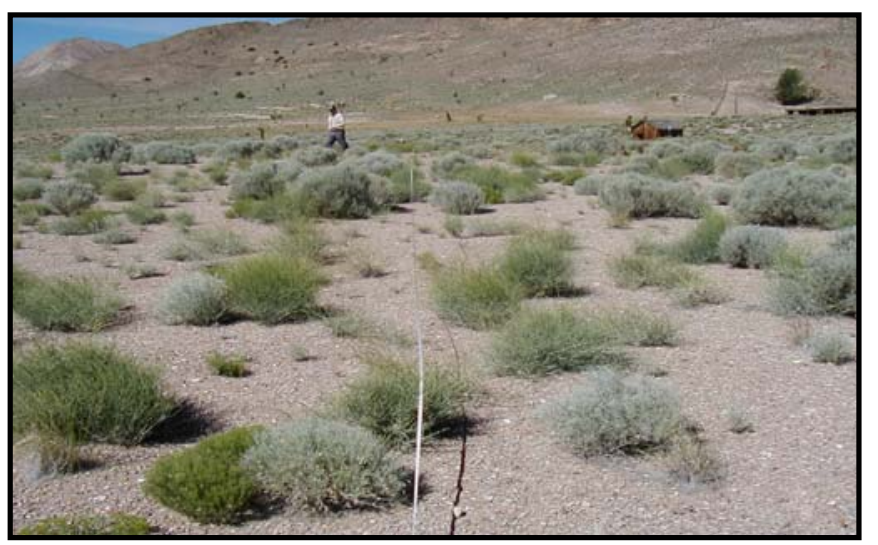

June 2005 
Post-Closure Inspection Report - TTR Revision: 0

Date: June 2006

\section{CAU 426-CACTUS SPRINGS STAGING AREA PHOTOGRAPHIC REFERENCE POINT}

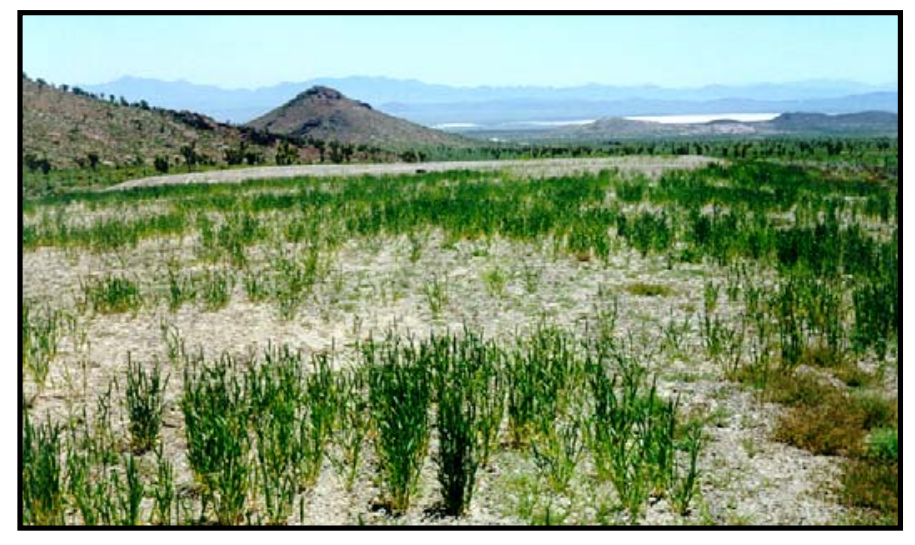

June 1998

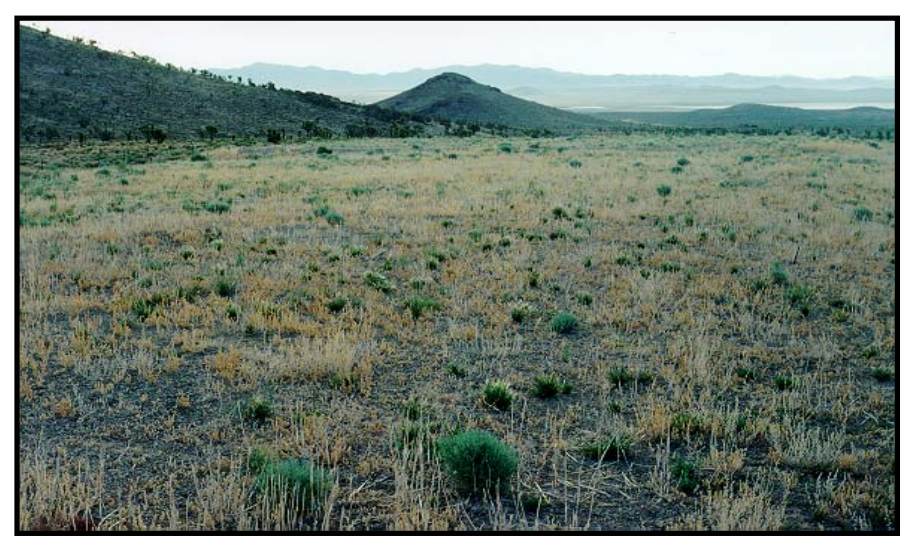

June 2002

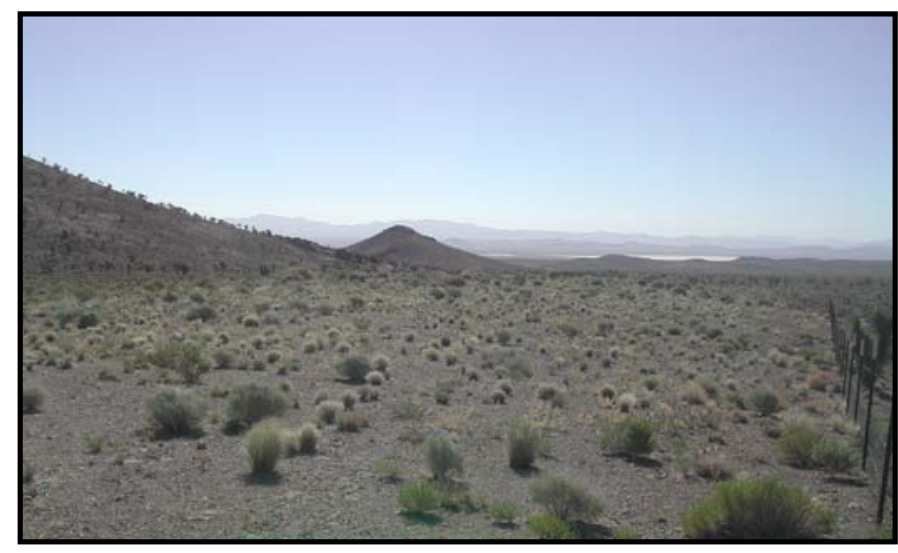

June 2004

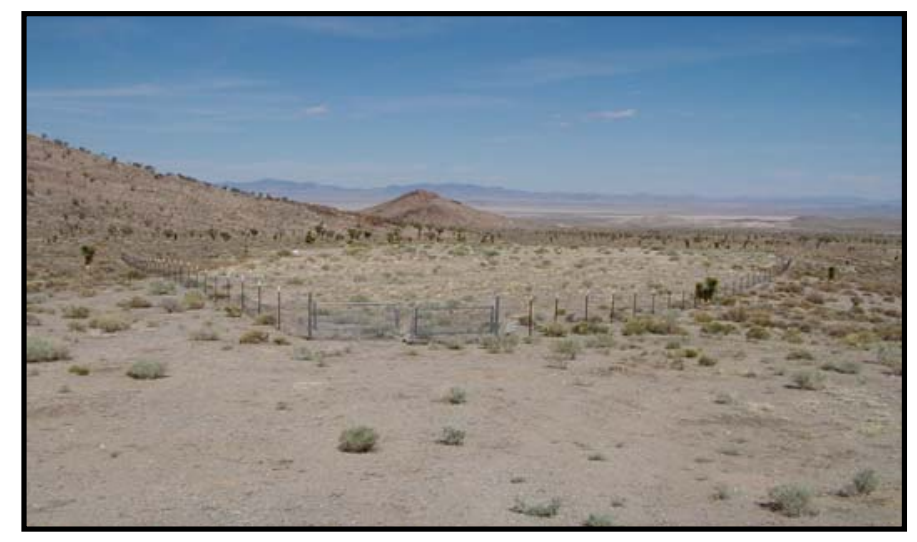

June 2000

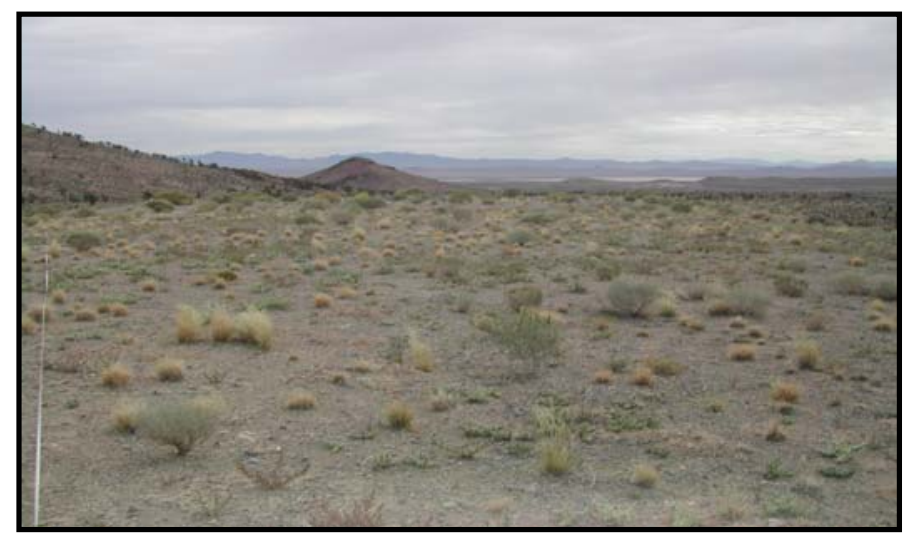

September 2003

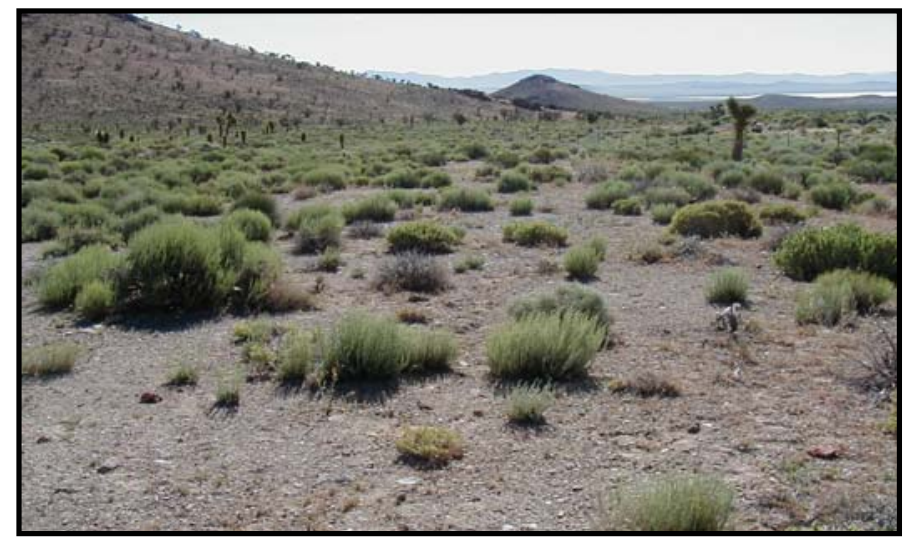

June 2005 
Post-Closure Inspection Report - TTR Revision: 0

Date: June 2006

\section{CAU 407-ROLLERCOASTER RADSAFE AREA PHOTOGRAPHIC REFERENCE POINT}

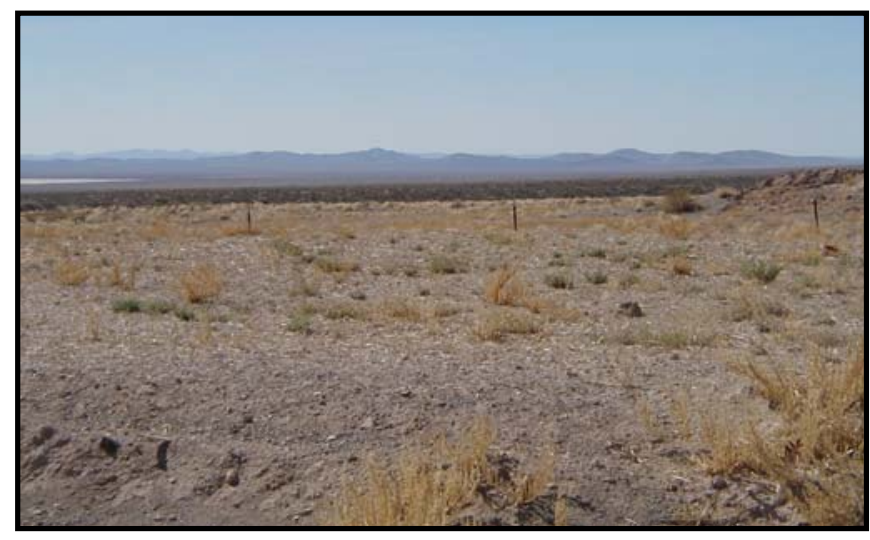

June 2002

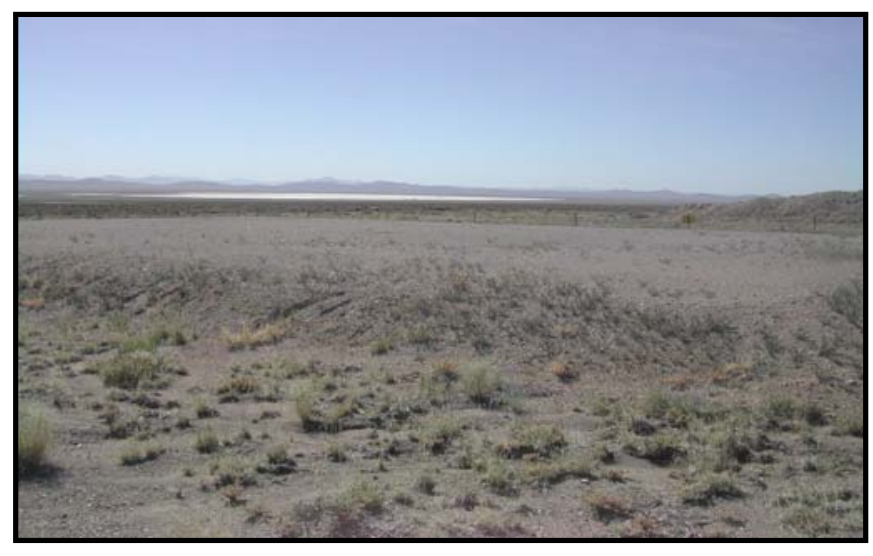

June 2004

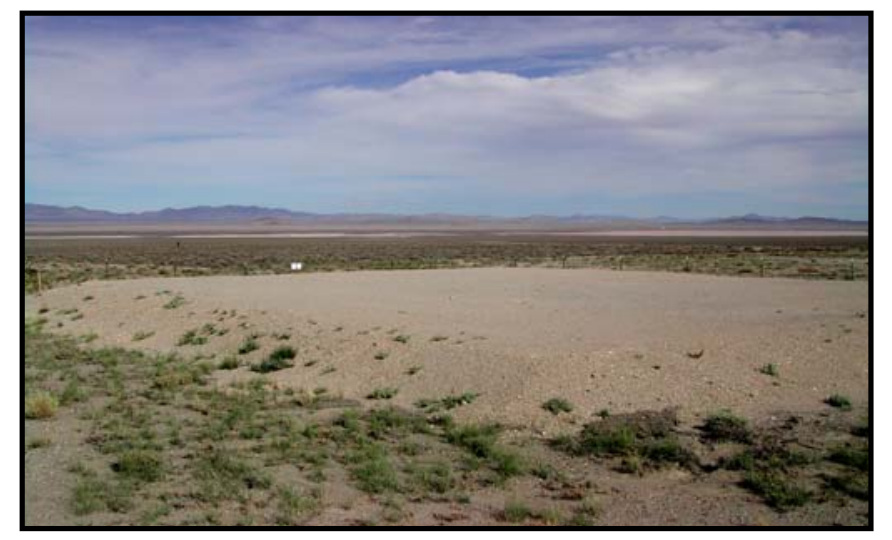

June 2003

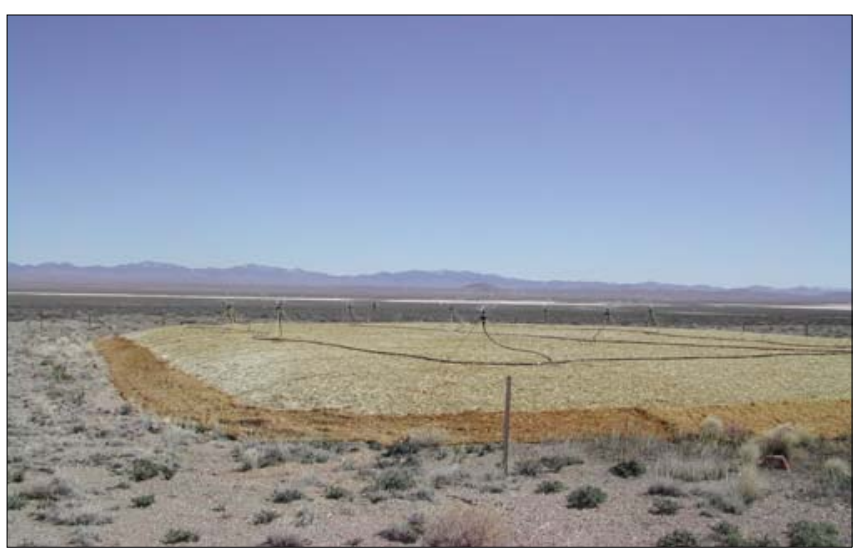

June 2005 
Post-Closure Inspection Report - TTR

Revision: 0

Date: June 2006

\section{APPENDIX F.2 \\ Plant Species List}

\begin{tabular}{|c|c|}
\hline \multirow{15}{*}{$\frac{\text { Lifeform }}{\text { Shrubs }}$} & $\underline{\text { Scientific Name }}$ \\
\hline & Artemisia nova \\
\hline & Artemisia spinescens \\
\hline & Atriplex canescens \\
\hline & Atriplex confertifolia \\
\hline & Chrysothamnus greenei \\
\hline & Chrysothamnus viscidiflorus \\
\hline & Ephedra nevadensis \\
\hline & Ericameria nauseosa \\
\hline & Gutierrezia sarothrae \\
\hline & Hymenoclea salsola \\
\hline & Krascheninnikovia lanata \\
\hline & Menodora spinescens \\
\hline & Opuntia pulchella \\
\hline & Sarcobatus vermiculatus \\
\hline \multirow[t]{7}{*}{ Grasses } & Achnatherum hymenoides \\
\hline & Elymus elymoides \\
\hline & Bromus tectorum \\
\hline & Dasyochloa pullcha \\
\hline & Pleuraphus jamesii \\
\hline & Sporobolus airoides \\
\hline & Sporobolus cryptandrus \\
\hline Forbs/ & Ambrosia species \\
\hline \multirow[t]{20}{*}{ Annuals } & Astragalus lentiginosa var. fremontii \\
\hline & Astragalus species \\
\hline & Camissonia boothii \\
\hline & Camissonia species \\
\hline & Chaneactis xantiana \\
\hline & Chenactis steviodes \\
\hline & Chenopodium album \\
\hline & Cryptantha circumscissa \\
\hline & Cryptantha micrantha \\
\hline & Cryptantha species \\
\hline & Cymopterus species \\
\hline & Descurania pinnata \\
\hline & Eriastrum eremicum \\
\hline & Eriastrum sparsiflorum \\
\hline & Eriogonum deflexum \\
\hline & Eriogonum nidularium \\
\hline & Eriogonum species \\
\hline & Eriogonum species \\
\hline & Erodium cicutarium \\
\hline & Gilia nyensis \\
\hline
\end{tabular}

Common Name

Black sagebrush

Bud sagebrush

Fourwing saltbush

Shadscale saltbush

Greene's rabbitbrush

Low rabbitbrush

Nevada jointfir

Rubber rabbitbrush

Broom snakeweed

White burrobrush

Winterfat

Spiny menodora

Sand cholla

Black greasewood

Indian ricegrass

Bottlebrush squirreltail

Cheatgrass

Low woollygrass

Galleta grass

Alkali sacatoon

Sand dropseed

Ragweed

Fremont's milkvetch

Milkvetch

Booth's suncup

Suncup

Xantus pincushion

Steve's pincushion

Lambsquaarters

Cushion cryptantha

Red root cyrptantha

Cryptantha

Springparsley

Pinnate tansymustard

Desert woolstar

Fewflower woolstar

Flatcrown buckwheat

Birdnest buckwheat

Buckwheat

Buckwheat

Filaree

Nye gilia 


\title{
APPENDIX F.2 (continued) Plant Species List
}

\author{
Lifeform $\quad$ Scientific Name \\ Forbs/ Gilia species \\ Halogeton glomeratus \\ Ipomopsis polycladon \\ Lepedium flavum \\ Lepedium lasiocarpum \\ Lepedium montanum \\ Lepedium species \\ Lupinus species \\ Macheranthera canescens \\ Mentzelia albomarginatus \\ Mirabilus biglovei \\ Oenothera species \\ Phacelia crenulata \\ Phacelia species \\ Salsola tragus \\ Sphaeralcea ambigua \\ Stephanomeria exigua \\ Tiquilia plicatas
}

Common Name

Gilia

Halogeton

Manybranched gilia

Yellow pepperweed

Shaggyfruit pepperweed

Mountain pepperweed

Pepperweed

Lupine

Hoary macharanthra

White blazingstar

Bigelow's four-o'clock

Eveningprimrose

Cleftleaf wildheliotrope

Phacelia

Prickly Russian thistle

Desert globemallow

Small wirelettuce

Fanleaf tiquilia 


\section{APPENDIX F.3 EROSION CONDITION CLASSIFICATION}

\begin{tabular}{|c|c|c|c|}
\hline Surface Litter & Pedestalling & $\underline{\text { Rills }<9 "}$ & Rills > 9" \\
\hline$\overline{1 \text { Accumulating in place }}$ & 1 No visual evidence & 1 No visual evidence & 1 No visual evidence \\
\hline 2 Slight Movement & 2 Slight pedestalling & $\begin{array}{l}2 \text { Rills in evidence } \\
\text { at intervals }>10^{\prime}\end{array}$ & $\begin{array}{l}2 \text { Rills in evidence } \\
\text { at intervals }>10^{\prime}\end{array}$ \\
\hline 3 Moderate Movement & $\begin{array}{l}3 \text { Small rock \& plant } \\
\text { pedestalling }\end{array}$ & 3 Rills at $10^{\prime}$ intervals & 3 Rills at 10 intervals \\
\hline 4 Extreme movement & $\begin{array}{l}4 \text { Pedestalling } \\
\text { plants roots } \\
\text { exposed }\end{array}$ & $\begin{array}{l}4 \text { Rills at 5-10' } \\
\text { intervals }\end{array}$ & $\begin{array}{l}4 \text { Rills at 5-10' } \\
\text { intervals }\end{array}$ \\
\hline $\begin{array}{l}5 \text { Very little remaining } \\
\text { litter }\end{array}$ & $\begin{array}{l}5 \text { Most plants \& } \\
\text { rocks pedestalled \& } \\
\text { roots exposed }\end{array}$ & $\begin{array}{l}5 \text { Rills at }<5^{\prime} \\
\text { intervals }\end{array}$ & $\begin{array}{l}5 \text { Rills at }<5 \\
\text { intervals }\end{array}$ \\
\hline Rating & Rating & Rating & Rating \\
\hline & & & Total \\
\hline Numerical Rating & \multicolumn{2}{|c|}{ Erosion Condition Class } & \\
\hline 0.0 to 4.0 & \multicolumn{2}{|l|}{ Stable } & \\
\hline 4.1 to 8.0 & \multicolumn{2}{|l|}{ Slight } & \\
\hline 8.1 to 12.0 & \multicolumn{2}{|c|}{ Moderate } & \\
\hline 12.1 to 16.0 & \multicolumn{2}{|c|}{ Critical } & \\
\hline 16.1 to 20.0 & \multicolumn{2}{|c|}{ Severe } & \\
\hline
\end{tabular}


Post-Closure Inspection Report - TTR

Revision: 0

Date: June 2006

\section{LIBRARY DISTRIBUTION LIST}


Post-Closure Inspection Report - TTR

Revision: 0

Date: June 2006

THIS PAGE INTENTIONALLY LEFT BLANK 


\section{LIBRARY DISTRIBUTION LIST}

U.S. Department of Energy

National Nuclear Security Administration

Nevada Site Office

Technical Library

P.O. Box 98518, M/S 505

Las Vegas, NV 89193-8518

U.S. Department of Energy

Office of Scientific and Technical Information

P.O. Box 62

Oak Ridge, TN 37831-0062

Southern Nevada Public Reading Facility

c/o Nuclear Testing Archive

P.O. Box 98521, M/S 400

Las Vegas, NV 89193-8521

Manager, Northern Nevada FFACO

Public Reading Facility

c/o Nevada State Library \& Archives

Carson City, NV 89701-4285
1 (Uncontrolled)

1 (Uncontrolled, electronic copy)

2 (Uncontrolled, electronic copies)

1 (Uncontrolled, electronic copy) 
Post-Closure Inspection Report - TTR

Revision: 0

Date: June 2006

THIS PAGE INTENTIONALLY LEFT BLANK 